\title{
Drömmar och röster - en antologi om barns och ungas livsvillkor i Malmö
}

Anne Harju \& Jonas Sjölander (red)

Malmö University Publications in Urban Studies 24 
Tryckbidrag har erhållits från Craafordska stiftelsen

(c) Copyright: Författarna

Malmö University Publications in Urban Studies 24

Institutionen för Urbana Studier, Malmö universitet www.mau.se

Tryck: Holmbergs, Malmö 2019

Layout och form: Fredrik Björk

Omslagsbild: Hilda Metz, Ta ingen skit

ISSN 1654-6881

ISBN 978-91-87997-14-3 (tryck)

ISBN 978-91-87997-15-0 (digital) 


\section{INNEHÅLL}

$\begin{array}{ll}\text { Bildförteckning } & 5\end{array}$

$\begin{array}{ll}\text { Författarpresentation } & 6\end{array}$

Drömmar och röster - en antologi om barns och ungas livsvillkor i Malmö

Annette Harju \& Jonas Sjölander

Dikt av Nathaniel Yaw Ankomah

Några lärdomar från Malmökommissionen.Har Malmö visat vägen?

Sven-Olof Isacsson

Ungdomsproblem i "utsatta områden": Komplexa orsaks-

förklaringar och reduktionistiska lösningar

Vanja Lozic

Ungdomar - problem eller potential?

Jonas Alwall \& Mikael Stigendal

Brandväggsprincipen - att säkerställa papperslösa barn och ungas rättigheter i Malmö

Linus Hermansson, Jacob Lind \& Hanna Scott

Bilder från utställningen Malmö, vad drömmer du om

Malmöbarns vardag i hemlöshet

Annelie Björkhagen \& Maria Hjortsjö

Unga i Malmö om staden, bostadsområdet och talet om

Anne Harju, Erica Ingemansson \& Jakob Tornberg

Att navigera i ett villkorat stadsrum. Malmötjejer om (o)tillhörighet, rörelsemönster och platsskapande 
"Det har inte med mig att göra" - om unga killars upplevelser av otrygghet i det offentliga rummet

Susanne Egnell \& Anna-Karin Ivert

STUNDA: Mobilapplikationen som verktyg för ökad kunskap om (o)trygghet och oro för brott bland unga vuxna i Malmö

Karl Kronkvist \& Alexander Engström

Elever som subjekt och aktörer med potential - om historieundervisningens existentiella relevans

Jonas Sjölander

Texter från utställningen Malmö, vad drömmer du om 
Fördomar

Isabel Appelfeldt Ariza

The Reincarnation of Themis

Martin Åkesson

Trygghet på Malmös gator

Sandra Persson

Frihet

Josefine Feldthus

Jag

Embla Krantz

Ingenting utan en dröm

Elise Löf

Sluta Skjuta

Ronja Ramserdal 


\section{Författarpresentationer}

Elever vid Malmö latinskola som bidrar med texter och bilder från utställningsprojektet Malmö; vad drömmer du om?

Sven-Olof Isacsson är läkare, specialist i invärtesmedicin och kardiologi och professor emeritus i socialmedicin vid medicinska fakulteten, Lunds Universitet. Han har under mer än tjugo år varit verksam som överläkare vid Universitetssjukhuset i Malmö med ansvar för att ta fram hälsodata om Malmös befolkning. Han medverkade också vid uppbyggnaden av Malmö högskola där han är hedersdoktor. Huvudintresset under många år har varit att omsätta forskning om befolkningens hälsa i praktisk verksamhet. Isacsson var ordförande i Malmökommissionen under åren 2011-2013. Vanja Lozic är lektor i pedagogik vid Malmö universitet och docent i utbildningsvetenskap med inriktning mot historiedidaktik. Som en del av samverkan mellan Malmö stad och Malmö universitet arbetar han som forskningsledare vid Malmö stads skolutvecklingsenhet Pedagogiska inspiration. Hans forskning är tvärvetenskaplig och handlar om samverkans ökade betydelse för att lösa olika samhällsproblem samt etniska relationer i och utanför skolan.

Jonas Alwall är universitetslektor i Internationell migration och etniska relationer och har under åren rört sig mellan ämnen som religionsvetenskap och mer sociologiskt inriktade perspektiv på det mångkulturella samhället, samt sociala insatser för utsatta grupper och - inom fältet urbana studier - frågor om socialt och kulturellt hållbar stadsutveckling. Mikael Stigendal är professor i sociologi vid Urbana Studier och har i flera decennier undrat hur samhället hänger ihop. Han har bedrivit mycket forskning om städer för att ta reda på det, då för det mesta tillsammans med bland annat ungdomar i vad Malmökommissionen kallade kunskapsallianser. Stigendal var en av kommissionärerna i Malmökommissionen.

Linus Hermansson är diakon i Angereds församling och arbetade tidigare i Fosie församling, Malmö. Han har en fil.mag. i Mänskliga Rättigheter och har varit medlem i Rädda Barnens riksstyrelse. Som diakon arbetar han med rättighetsbaserat stöd till människor på flykt och i ekonomisk utsatthet och han har även tagit fram en handbok för arbete med barnkonsekvensanalyser i Svenska kyrkan. Jacob Lind är doktorand 
i ämnet internationell migration och etniska relationer vid Malmö Universitet. Hans avhandling handlar om hur barn och familjer navigerar sig i en vardag präglad av papperslöshet och de politiska processer som främst påverkar deras tillvaro. Aktörskap, utsatthet(-görande) och rättigheter är centrala koncept som avhandlingen problematiserar och reflekterar kring i denna kontext. Hanna Scott är doktorand i välfärdsrätt vid Linköpings universitet där hon genomför ett forskningsprojekt om brottsutsatthet och överlevnadsstrategier bland unga utan papper. Hon är för närvarande tjänstledig från sitt jobb som jurist vid Unga forum, Skåne stadsmission där hon under fyra år arbetat med råd och stöd till barn och unga på flykt.

Annelie Björkhagen är universitetslektor i socialt arbete vid Malmö universitet och forsknings- och utvecklingskoordinator i Malmö stad. Hon har även arbetat många år med socialt arbete med utsatta familjer i Malmö stad. Maria Hjortsjö är socionom, fil $\mathrm{dr}$ i socialt arbete och verksam som lektor vid institutionen för socialt arbete, Malmö universitet. Hennes forskningsintressen handlar om barn och familj i utsatta livssituationer, tillämpandet av barnkonventionen i den sociala välfärden samt den sociala barnavårdens organisering.

Anne Harju är universitetslektor och docent i barn- och ungdomsvetenskap vid Malmö universitet. Hennes huvudsakliga forskningsområde är barndomsstudier, med ett specifikt fokus på barn och ungdomar i utsatta situationer. Hennes forskning rör också utbildningsfrågor med fokus på migration. Erica Nordbeck Ingemansson arbetar idag som personlig handläggare på Försäkringskassan. Hon arbetade under åren 2015-2016 som projektledare i barnrättsorganisationen Reach for Change, som finansierade studien som ligger till grund för antologibidraget. Jakob Tornberg är doktorand i socialt arbete på Malmö universitet och hans forskning rör arbetslöshet och kommunala insatser inom ramen för försörjningsstödet. Utöver detta är Jakob knuten till Centrum för sexologi och sexualitetsstudier.

Johanna Sixtensson är fil.dr i socialt arbete och biträdande lektor med inriktning mot barn och ungdomar vid institutionen för socialt arbete, Malmö universitet. Hennes forskningsintressen är främst inriktade mot ungdomar och ungdomars aktörskap, urbana frågor, segregation och marginaliseringsprocesser och förebyggande socialt arbete med barn och unga.

Susanne Egnell är doktorand i Hälsa och samhälle med inriktning kriminologi och Anna-Karin Ivert är docent i kriminologi, båda vid institutionen för kriminologi vid Malmö universitet. De har på olika sätt forskat om otrygghet och oro för brott bland vuxna och ungdomar i Malmös olika delområden. Ofta har detta gjorts i samarbete med Malmö stad och lokala nätverk för områdesutveckling.

Karl Kronkvist är doktorand och universitetsadjunkt vid institutionen för kriminologi, Malmö universitet. Hans huvudsakliga intresseområden rör frågor om varför 
vissa platser är mer brottsdrabbade än andra och varför vissa miljöer upplevs som mer otrygga än andra. Temat $\mathrm{i}$ hans avhandling handlar om brottsförebyggande och trygghetsskapande arbete i urban miljö samt alternativa metoder för datainsamling. Alexander Engström är doktorand vid institutionen för kriminologi, Malmö universitet. Hans forskningsintressen kretsar kring hur ungdomars delaktighet i kriminalitet, utsatthet för brott och överlappningen mellan brottsdeltagande och utsatthet för brott kan kopplas till olika livsstilsfaktorer. Ett annat intresseområde består av att utveckla forskningsdesigner och datainsamlingsinstrument för att ge alternativ till mer traditionella metodologiska angreppssätt inom kriminologisk forskning.

Jonas Sjölander är docent i historia och forskningsledare vid Pedagogisk inspiration (Pi) i Malmö stad. Han har tidigare varit verksam som forskare och undervisande universitetslektor vid Linnéuniversitetet, Lunds universitet och Malmö högskola. I sin nuvarande roll är han involverad i verksamheter som rör följeforskning och andra insatser inom Malmö stads skolförvaltningar samt samverkansprojekt mellan kommun och universitet. 


\title{
Drömmar och röster - en antologi om barns och ungas livsvillkor i Malmö
}

\author{
Anne Harju \& Jonas Sjölander
}

\section{ETT ANTOLOGIPROJEKT I SAMVERKAN MELLAN MALMÖ STAD OCH MALMÖ UNIVERSITET}

Den här antologin har till syfte att uppmärksamma barns och ungas livsvillkor i Malmö. Vissa av bidragen fokuserar på barn och unga indirekt via praktiker, medan andra berör deras erfarenheter mer direkt. Antologibidragen ger därmed inblick i hur barns och ungas vardag påverkas och begränsas av de materiella och sociala villkoren som finns i staden men också hur de själva erfar, använder och skapar sina och andras livsvillkor i den. Genom att betona såväl strukturella och institutionella aspekters påverkan som barn och unga som subjekt med potential, synliggörs inte bara dessa materiella och sociala villkor utan också hur de kan förändras och omskapas.

Unga som subjekt är en viktig utgångspunkt $\mathrm{i}$ antologin genom att perspektiven $\mathrm{i}$ största möjliga mån utgår från barn och unga på deras egna villkor och att de är synliga i texterna som subjekt. Barn och ungas agentskap i urbana miljöer knyts sällan till diskussioner som rör socio-politiska aspekter och strukturella övergripande sammanhang, trots att deras vardagsliv de facto är tätt sammanlänkat med dessa kontexter. Vår gemensamma utgångspunkt i den här antologin är att barns och ungas livsvillkor, personliga erfarenheter och subjektspositioner behöver förstås i förhållande till såväl de vardagliga mikrorummen, de offentliga miljöerna i staden och dess sociala geografi, som till de stora sociopolitiska och strukturella sammanhangen. Detta gäller såklart inte minst i en dynamisk kulturellt och socioekonomiskt diversifierad stad som Malmö där hälften av befolkningen är under 30 år, där 170 nationaliteter är representerade och där mer än 150 språk talas. Denna sociala och kulturella geografi medför utmaningar för professioner som arbetar med barn och ungdomar, som kräver medvetenhet om deras livsvillkor, vilket också behöver tillmätas pedagogisk mening och betydelse i professionsutövning och forskning.

I Malmökommissionens 31 underlagsrapporter och dess huvudrapport (2013) konstaterades att klyftorna och skillnaderna mellan olika delar av befolkningen 
i Malmö hade ökat påtagligt under de senaste decennierna. Kommissionen gjorde djupdykningar som täckte en rad aspekter som migration, hälso- och sjukvård, trygghet, utbildning och socio-ekonomiska förhållanden. Barn och ungas vardagsvillkor lyftes fram som ett särskilt viktigt område och därför vill vi med denna antologi knyta an till och återanknyta till Malmökommissionens intentioner. I ett av huvudrapportens avsnitt som berör barn och ungas livsvillkor i Malmö formulerades exempelvis ett antal inriktningsmål och åtgärder. Ett av dessa mål var att halvera barnfattigdomen år 2020 och på sikt eliminera den helt. Det har nu hunnit bli 2019 och fortfarande har Malmö högst andel fattiga barn i landet. Åtgärdsförlagen i rapporten har inte hamnat högt på dagordningen, tycks det. Även om barnfattigdomen i Malmö inte diskuteras explicit i alla bidrag $i$ antologin anser vi att det är nödvändigt att påminna om de rekommendationer, intentioner och målsättningar som Malmökommissionen lade fram för stadens beslutsfattare. Antologins tematik - barns och ungas livsvillkor $i$ Malmö - kräver helt enkelt detta.

Vissa av bidragen i antologin är lösnings- och potentialorienterade, medan andra kritiskt nagelfar förhållanden så som de gestaltas i staden för barn och unga. Text och bildinslagen från utställningen Malmö, vad drömmer du om, producerade av elever från språkintroduktionen och de estetiska programmen vid Malmö Latinskola, förstärker och befäster ytterligare vårt syfte med antologin.

\section{PRESENTATION AV ANTOLOGIBIDRAGEN}

Inledningsvis ger vi ordet till Hilde Selander från Kulturföreningen Imagenes del sur som är projektledare för Malmö, vad drömmer du om?

"Vi är samma stoff som drömmar görs av", skrev Shakespeare och mer än 300 år senare uttalade Martin Luther King orden " I have a dream.." Långt tidigare har människan haft drömmar om framtiden, ett ljusare och bättre liv, positiva utmaningar. Människor fortsätter att drömma. Vad drömmer Malmöborna om? Vad drömmer ungdomar i Malmö om?

Kan kultur skapa en gemensam mötesplats där drömmar, tankar och kreativitet vävs ihop till ett gemensamt konstnärligt uttryck?

Projektet vill bidra till att öka förståelsen för varandra och se likheter istället för skillnader - söka och hitta positiva förebilder som kan stärka den egna identiteten. Kan det skapa större förståelse för andra och en tryggare förankring i sig själv? Tillsammans med ungdomar och fristadsförfattare ska vi med hjälp av kultur och samtal utveckla verktyg för att kunna förena olika elevgrupper, tackla tuffa tider och vända det negativa till att kunna göra något positivt.

Vi har nu arbetat med Latinskolans medieelever och Språkintroduktionselever under ett år. Det resulterade i en utställning på Malmö Stadshus, MKB Lorensborg 
och MKB Studenthus Rönnen; en katalog, vykort och affischer allt baserad på bilder och texter av eleverna.

Projektet kommer att pågå i totalt tre år då vi tillsammans med ungdomar på Malmö Latinskola och Apelgårdsskolan ska möta, samtala med och inspireras av Malmös fristadsförfattare. Dessa författare har varit utsatta för censur och/eller förföljelse i sitt hemland och har nu fătt ett tvåårigt stipendium i Malmö. Fristadsprogrammet handlar om att säkra yttrandefriheten och allas rätt att framföra sina synpunkter offentligt. Utgångspunkten i projektet är dokumentera och sprida elevernas drömmar, kreativa förmåga och samspel med vuxna inspiratörer, fristadsförfattare och andra elever som är födda i eller utanför Sverige. Materialet samlas och bearbetas till tre utställningar och en metodbok som projektets slutresultat år 3. Projektet vänder sig till ungdomar mellan 14 och 25 år. Vi fokuserar på gymnasieskolan och högstadiet. Projektet är finansierad av Allmänna Arvsfonden. Vi samarbetar med ABF Malmö.

Sven-Olof Isacssons bidrag är en subjektivt presenterad och unik berättelse om Malmökommissionens tillkomst, arbete och resultat som när den speglas mot övriga texter i antologin får en särskild betydelse och mening. Här beskriver den dåvarande ordföranden för den politiskt oberoende kommissionen processen fram till dess att slutrapporten överlämnades till politikernas ansvar att göra "verkstad" av väl underbyggda förslag till åtgärder.

Vanja Lozic analyserar i sitt bidrag de sätt representanter för socialtjänst, polis, skola, offentlig sektor och frivilligorganisationer problematiserar orsaker till ungdomsproblem i ett så kallat utsatt område. Vidare diskuteras åtgärder som anses vara eftersträvansvärda. Studien visar att även om organisationsrepresentanterna identifierar flera strukturella problem och lösningar kretsar majoriteten av föreskrivna lösningar kring styrning av familjen.

Jonas Alwalls och Mikael Stigendal tar i bidraget "Ungdomar - problem eller potential?" utgångspunkt i hur ungas problem i dagens urbana miljöer, inte minst i Malmö, ofta beskrivs som en fråga om dessa ungas destruktiva livsstil. Ett sådant perspektiv tenderar dock att bortse från de bakomliggande orsakerna till problemen. I stället för det problemorienterade förhållningssätt som ofta präglar insatser riktade mot unga vill kapitlet lyfta fram ett annat förhållningssätt - ett potentialorienterat som inte begränsar sig till problem som lätt kan identifieras (symptom) utan i stället fokuserar dessa problems orsaker och ungas egen handlingskraft. Fritidsverksamheten Gnistan i Malmö, som särskilt lyfts fram i kapitlet, är exempel på en verksamhet som författarna menar präglas av ett potentialorienterat förhållningssätt, om än delvis implicit och med stor möjlighet att utvecklas ytterligare.

Linus Hermansson, Jacob Lind och Hanna Scott argumenterar i sitt bidrag för vikten av att omsätta barnrättsperspektivet i konkret praktik. Papperslösa barn har en lagstadgad och konventionsgrundad rätt till en bred katalog av grundläggande rättigheter som till exempel vård och skola. Internationella rättighetsorgan, forskare och praktiker har dock fastslagit att för att säkerställa dessa rättigheter är så kallade "brandväggar" nödvändiga. Arbetet med att utöka papperslösa personers tillgång till 
rättigheter behöver kombineras med ett införande och försvarande av brandväggar för att rättigheter ska fungera i praktiken. Kapitlet diskuterar hur brandväggar förhandlas, utmanas och byggs upp på olika nivåer i samhället och vilka praktiska konsekvenser brandväggsprincipen kan ha för rättighetsarbete med papperslösa barn i Malmö.

Anneli Björkhagen och Maria Hjortsjö skildrar i sitt bidrag hemlösa barns vardagsliv i Malmö. Att vara hemlös innebär att föräldrarna saknar ett eget bostadskontrakt. Barnen har fotograferat sitt vardagsliv och utifrån dessa bilder har författarna sedan samtalat med barnen om vad det innebär att vara barn och sakna ett hem. Antologibidraget bygger på dessa berättelser. Studien som helhet handlar om att tydliggöra hur barnens behov och rättigheter beaktas i socialtjänstens arbete.

Anne Harju, Erica Nordbeck Ingemansson och Jakob Tornberg tar utgångspunkt i unga människors upplevelser och erfarenheter av mediabilder, bostadsområden och staden Malmö. Resultatet, som bygger på en enkätstudie samt intervjuer, visar att de unga har en tudelad bild av sin stad, men att positiva erfarenheter och tankar om Malmö och det egna bostadsområdet är vanligast förekommande. Malmö anses också bli allt mer segregerat vad gäller möten mellan unga. Genomgående läggs ansvaret för skapandet av mötesplatser på de vuxna, vilket kräver att vuxna på allvar antar utmaningen om att förhandla om den komplexitet och mångfald som finns i Malmö.

Johanna Sixtensson bidrar med en text om unga tjejers förhandlingar om rum och plats i det offentliga rummet. Antologibidraget tar sin utgångspunkt i en grupp tonårstjejers berättelser om deras vardagsliv i Malmö. Genom deras berättelser exemplifieras hur maktstrukturer och skillnadsskapande processer tar sig rumsliga uttryck samt hur platser och rum bär på starka föreställningar om vem som bor där eller vem platsen är till för. I texten åskådliggörs hur konstruktioner av svenskhet, ekonomisk position, men också kön som maktordning påverkar tjejernas känslor av (o)tillhörighet samt rörelsemönster i stadsrummet.

Susanne Egnell och Anna-Karin Ivert skriver om unga killars erfarenhet av (o) trygghet i det offentliga rummet och staden. Bidraget bygger på intervjuer med unga killar från två områden i Malmö som i tidigare undersökningar beskrivits som några av de mest otrygga i staden. I kapitlet presenterar författarna killarnas upplevelser av otrygghet i det offentliga rummet. Men kapitlet handlar också om att med utgångspunkt i killarnas berättelser synliggöra och lyfta fram ungdomars erfarenheter och upplevelser av dessa områden. Ofta bygger problemformuleringarna och beskrivningarna av de här områdena på vuxnas erfarenheter och upplevelser och den bild som målas upp i media och av politiker.

Karl Kronkvist och Alexander Engström presenterar en konkret och ny metod för att kartlägga och undersöka unga personers otrygga miljöer. I bidraget diskuteras inledningsvis ett par tillkortakommanden med konventionella metoder inom kvantitativ kriminologisk trygghetsforskning och hur dessa medför begränsad kunskap om otrygghet, inte minst bland unga personer. Med utgångspunkt $i$ en lokal studie ges förslag på hur kunskap om otrygghet bland unga i Malmö kan utökas genom att samla in data med en egenutvecklad mobilapplikation (STUNDA). Kapitlet fokuserar på de 
erfarenheter som framkommit under pilotstudien, både i termer av metodologiska överväganden och i relation till den omedelbara miljöns inverkan på otryggheten.

Jonas Sjölander diskuterar i sitt bidrag historieämnet, den relationella pedagogiken och metoder för att skapa mening och existentiell relevans i historieundervisningen. I bidraget pläderas bland annat för betydelsen av underifrån-historiska perspektiv och ett grundläggande förhållningsätt där eleverna i staden Malmö erkänns som subjekt med potential, tillhöriga i och medskapare av staden och dess historia.

Vi vill avslutningsvis passa på att rikta ett stort tack till Craafordska stiftelsen för att man genom att bevilja projektet tryckbidrag möjliggjort bokens publicering. 
Malmö, o Malmö vackra stad Malmö.

Staden av ljus och elegans. Staden med flera möjligheter.

Staden som ger andra chans, mångkulturell stad, vacker stad Malmö.

Ibland verkar dina drömmar och visioner instabila och svängar som Turning torso. Du hittar dig själv på den andra sidan, borta från dina drömmar men allt du behöver är en bron som Öresundsbron för att fylla gapet och länka dig till dina drömmar.

Bor du i Malmö; så "kudos" eftersom i Malmö, dess manifestation är ett steg bort; i linje speciellt på Malmös broadway. Många är drömmarna och visionerna som invånarna i Malmö har. Om de bara kunde se hennes ljusa magnifika händer utsträckta mot dem, ge en hjälpande hand till dem för att uppnå sitt mål, de kan fånga det.

Så dröm stort, Malmö finns här för att dina drömmar ska bli sanna Malmö, VAD DRÖMMER DU?!!

Nathaniel Yaw Ankomah 


\section{Några lärdomar från Malmökommissionen. Har Malmö visat vägen?}

Sven-Olof Isacsson

\section{MÅSTE BÖRJA MED BARNEN}

Den här antologin har sitt fokus på barn och unga i Malmö. Barnperspektivet var också en av grundbultarna i Malmökommissionens arbete, vilket underströks i förordet till kommissionens slutrapport där de första raderna är hämtade ur Barnens manifest från Tage Danielssons film SOPOR. "Det är ingen idé att finnas till om man inte behövs till något. Därför måste samhället inrättas så att alla behövs. Vi kräver att behövas!" (Kommission för ett socialt hållbart Malmö 2013: 1). Det borde vara en självklarhet för alla som vill bidra till ett välfungerande framtida samhälle att inte ett enda barn lämnas i sticket. Malmös och Sveriges framtid hänger på att vi utgår från ett barnperspektiv. Mitt bidrag är en subjektiv och personlig berättelse om Malmökommissionen som reser frågor om hur politiker i en enskild kommun använder sig av kunskap som bas för att skapa ett friskare och mera jämställt samhälle med tyngdpunkten på barnoch ungdomsperspektivet.

En dag i oktober 2010 flyttade jag in i stadshuset. Det var någon månad efter ett samtal jag fått några veckor tidigare. Jag skulle snart fylla 75 år. Den som ringde var en person som hade ansvaret för folkhälsoarbetet i staden och som jag arbetat tillsammans med under flera år i slutet av nittiotalet. Vi träffades i stadshuset. Det var nästan tio år sedan jag hade varit där senast. Jag visste inte att man under våren tagit beslut i kommunstyrelsen om att tillsätta en kommission för att försöka minska ojämlikheterna i hälsa. Efter ett par möten hade jag klart för mig vad det handlade om. Det lät spännande. Kunde jag överväga att bli ordförande? Det var ett förtroendeuppdrag, mycket smickrande! Efter några möten med det ansvariga kommunalrådet Katrin Stjernfeldt Jammeh, lovade jag medverka under förutsättning att kommissionen skulle vara politiskt oberoende. Det var ett oväntat krav det förstod jag. Jag lovade att politikerna skulle kunna följa vårt arbete hela tiden men vår slutrapport måste grundas på fakta. Förslag som skulle kunna tolkas som partipolitiskt färgade var uteslutet. Det gick några dagar. Jag blev ändå överraskad när det blev ja till en politiskt oberoende 
kommission. Det blev ett mycket bra samarbete. Kommunalrådet höll sitt löfte och hon var hela tiden mycket nyfiken, var väl insatt i den pågående processen och stödde oss på alla sätt.

Den 5 maj 2010 hade kommunstyrelsen i Malmö beslutat att tillsätta en kommission för ett socialt hållbart Malmö. Bakgrunden var den sedan decennier påvisade ojämlika hälsan inom staden. Skillnaderna i livslängd mellan stadens olika delar uppgick till hela sju år. Knappt tre år senare, i mars 2013, kom slutrapporten från Malmökommissionen: Malmös väg mot en hållbar framtid. Hälsa, välfärd och rättvisa. Ytterligare ett år senare, den 5 mars 2014, beslutade kommunstyrelsen om "Det fortsatta arbetet för ett socialt hållbart Malmö-inriktning för Malmö stad 2014." Det byggde på de 74 åtgärder som kommissionen föreslog för att minska de sedan många år kända stora skillnaderna i hälsa i Malmö. Allt gick fort. Hade man verkligen tillräckligt på fötterna för att genomföra ett så omfattande program i landets tredje stad? Hur vågade man? För närvarande pågår en omfattande utvärdering som skall vara klar 2020. Men den här artikeln handlar inte om utvärderingen, den handlar om hur förberedda och pålästa politiker och tjänstemän egentligen var innan de satte snöbollen i rullning. Det här var unikt i både ett lokalt och i ett nationellt perspektiv. Det är tillkomsten av en kommission med forskare och experter men utan politiker som diskuteras i det här kapitlet. Det kan vara lärorikt för läsaren att ta del av kommissionens sätt att arbeta och samspelet mellan forskare, politiker och det omgivande samhället, när allt fler i dagens samhälle tenderar att ifrågasätta fakta. Att ha en pålitlig bild av hur verkligheten ser ut i dagens alltmer komplexa samhälle är ovärderligt vid genomförandet av resursslukande insatser. Här kommer min subjektiva berättelse i egenskap av kommissionens ordförande under åren 2011 - 2013. Varifrån kom inspirationen? Fanns kompetens lokalt? Skulle det bli ytterligare en rapport som snart var glömd?

\section{VARIFRÅN KOM INSPIRATIONEN?}

Förebilden för Malmökommissionen var en uppmärksammad rapport från WHO (Världshälsoorganisationen): Closing the gap in a generation (WHO 2008, 2). Det var slutrapporten från Commission on social determinants of health, ledd av professor Sir Michael Marmot från London. Utgångspunkten för arbetet var de oacceptabla och systematiska skillnaderna i hälsa inom och mellan länder. Genom politiska åtgärder och program ville WHO-kommissionen påverka de sociala bestämningsfaktorerna och därigenom skapa en mer jämlik hälsa. Det skulle kräva strukturella insatser. WHO-kommissionen, även kallad Marmotkommissionen, bestod av 19 kommissionärer med olika expertis inom forskning, politik och policyfrågor. Den dominerades av forskare men även en och annan tung politiker (som $t$ ex den tidigare presidenten i Chile Ricardo Lagos och Kanadas tidigare hälsominister Monique 
Bégin). Flera hundra forskare och andra experter från hela världen, varav några från Sverige, medverkade i insamlandet av underlag. I slutrapporten fastslogs att trots att hälsan förbättrats de senaste 30 åren var hälsoklyftorna enorma med upp till 40 års skillnad i förväntad medellivslängd mellan länder. Även inom länder fanns stora hälsoskillnader, nära förbundna med sociala förhållanden. Inom EU uppmanades medlemsländerna att påbörja arbetet med att främja effektiva åtgärder mot underliggande faktorer av socioekonomiska skillnader i hälsa. England var först på plan. I Sverige översatte dåvarande Statens Folkhälsoinstitut rapporten till svenska och kom med förslag till ett nationellt program på uppdrag av regeringen (Statens folkhälsoinstitut 2013,3). Det blev tummen ner från regeringen, kanske av ideologiska skäl. Flera år senare tillsatte den nya regeringen en nationell kommission (SOU:17, 2017, 4). I flera delar av landet var intresset stort. Ett nätverk av kommuner och landsting bildades och olika aktiviteter diskuterades. I Malmö beslöt kommunstyrelsen att tillsätta en kommission med WHO som förebild. Malmö var först på plan. Anledningen till malmöpolitikernas intresse var sannolikt en sedan många år gedigen kunskap om den ojämlika hälsan och hur den relaterade till olika sociala faktorer. Flera projekt hade genomförts för att minska hälsoskillnaderna. Oavsett politisk ledning i kommunen bedrevs ett folkhälsoarbete mer eller mindre intensivt. Hälsoläget studerades, årliga välfärdsredovisningar genomfördes, förebyggande åtgärder bedrevs för att påverka livsstilen. Det mesta var relativt väl underbyggt utgående från de kunskaper som fanns om orsakerna till sjukdom och död i förtid. Men den ojämlika hälsan fanns kvar. År 1991 publicerades den första folkhälsorapporten från Malmö (Nilsson, Hansson \& Isacsson, 1991, 5). Det var en vetenskapligt väl underbyggd studie där hälsodata konsekvent relaterades till en rad sociala bakgrundsfaktorer såsom inkomst, utbildning, ursprungsland, arbete, bostadsområde med mera. Den segregerade staden lyste igenom överallt. Skillnaderna i medellivslängd uppgick till hela sju år mellan stadens olika delar. Det var oacceptabelt. Men metoder saknades och därmed också åtgärder för att komma tillrätta med den ojämlika hälsan. Nya angreppssätt måste prövas. Det är här WHO rapporten kommer in. Ett par alerta personer på stadskontoret med lång erfarenhet och intresse för folkhälsoarbetet i Malmö hade följt diskussionerna i WHO rapportens kölvatten. Malmö stad deltog också i möten, nya rapporter lästes och WHO-kommissionens rekommendationer diskuterades direkt med den svenske forskare som varit en av de 19 kommissionärerna i WHO-kommissionen (professor Denny Vågerö). Det var uppenbart att åtgärder som ensidigt syftade till att påverka beteenden och livsstil inte räckte till. WHO-rapportens åtgärdsförslag var inriktade på samhällets strukturer; barn och ungas vardagsvillkor, boendemiljö och stadsplanering, utbildning, inkomst och arbete samt hälso-och sjukvården som system. Åtgärderna som WHO-kommissionen rekommenderade var väl underbyggda vetenskapligt och politiskt och i olika delar fullt möjliga att genomföra i Malmö. Ansvarigt kommunalråd för folkhälsoarbetet i Malmö, nuvarande kommunstyrelsens ordförande, socialdemokraten Katrin Stjernfeldt Jammeh, lät sig övertygas. Något mera drastiskt måste försökas. Ytterst var det ett ypperligt tillfälle att försöka angripa själva roten till ojämlikheterna och segregationen i Malmö. Den socialdemokratiska majoriteten 
beslutade tillsätta en kommission. Oppositionen morrade, men inte tillräckligt för att torpedera genomförandet. På hösten 2010 var arbetet i full gång.

\section{NU ÅTERSTOD KANSKE DETVIKTIGASTE. VILKA SKULLE INGA I KOMMISSIONEN?}

Lagstiftningen är tydlig: "I högskolornas och universitetens uppgift ska ingå att samverka med det omgivande samhället och informera om sin verksamhet samt verka för att forskningsresultat tillkomna vid högskolan kommer till nytta" (Lag 2009:45, 6). Villkoren i praktiken gör dock att hindren är många, framför allt är det ofta finansiering som saknas för universitetets tredje uppgift. I Malmö fanns det dock beredskap att finansiera insatser från forskarsamhället för att pröva mer radikala och vetenskapligt underbyggda åtgärder för att minska ojämlikheterna i hälsa. Men först behövdes en tillförlitlig och aktuell bild av hur hälsoläget såg ut, inte minst ur ett socialt perspektiv. Vilka förutsättningar fanns för att man skulle kunna ta fram de underlag som krävdes? Fanns det forskare i Malmö (eller i Lund) med relevant kompetens och intresse? Skulle det finnas intresse och kompetens bland tjänstemän och andra att genomföra den dialog med forskarsamhället som var en absolut förutsättning för att genomföra planerade åtgärder i staden Malmö? Av direktivet framgick tydligt att kommissionens förslag till åtgärder skulle vara vetenskapligt underbyggda. Medicinsk kompetens fanns inom räckhåll. Ända sedan Malmö Allmänna Sjukhus (MAS) år 1948 blev universitetssjukhus har den medicinska forskningen varit respekterad inom Lunds Universitets medicinska fakultet, inom landet och med tiden även internationellt. Forskning om sjukdomar och deras orsaker i befolkningen hade gjort MAS till "epidemiologins Mecka" (Ersgård 1996, 7). Publikationer om de stora folksjukdomarnas orsaker och möjligheter till förebyggande insatser var väl kända inom hela landet och även globalt (Malmö kost-cancer, rörelseorganens sjukdomar, studien förebyggande-medicin, män födda 1914, mammografistudier, åderförkalkningsstudier, diabetes $\mathrm{mm}$ ). Det fanns nu även forskning och kompetens inom andra områden än det medicinska. 1998 invigdes Malmö högskola (nu Universitet) och växte snabbt till att bli en av landets största högskolor med alltmer omfattande forskning och utbildning inom samhällsvetenskap, folkhälsovetenskap, vårdvetenskap och humaniora. Här fanns bred kompetens och intresse vilket var en förutsättning för att kunna bidra med vetenskapliga underlag som bas för strukturella insatser mot hälsans sociala bestämningsfaktorer. I början av år 2011 var kommissionens samansättning klar. Förutom ordförande och huvudsekreterare blev det åtta forskare med lång erfarenhet av forskning och utbildning inom relevanta områden. Sex var från Malmö (socialmedicin, epidemiologi, hälsoekonomi, socialt arbete, sociologi, pedagogik) och 
två från Stockholm (medicinsk sociologi samt pedagogik). Sex av kommissionärerna var personer med stor kunskap om Malmö (förvaltningschefer inom stadsplanering, socialtjänst, miljö samt experter inom barnhälsovård, utbildning och högskoleadministration). Ingen politiker. Kommissionen skulle vara politiskt oberoende. Det var sannolikt ett klokt men svårt beslut men som vittnade om tillit till kommissionens medlemmar.

\section{GENOMFÖRANDEPROCESSEN}

Arbetet kom igång på allvar i mars 2011. Vägledande var de tydliga direktiven för kommissionens arbete. Vi skulle utarbeta vetenskapligt underbyggda förslag på hur ojämlikheterna i hälsa i Malmö kunde minskas, utgående från sociala bestämningsfaktorer: vad är påverkbart, av vem och hur? Ekonomiska konsekvenser och effekter av insatser skulle redovisas i tre prioriterade områden: barns och ungas uppväxtvillkor; sociala och ekonomiska förutsättningar; demokrati och delaktighet. Vi bestämde att för varje relevant område skulle vetenskapligt underlag tas fram. Strukturen skulle vara densamma: För det första en genomgång av inhemsk och internationell litteratur. För det andra en presentation av vetenskapligt grundade åtgärder som var möjliga att genomföra i praktiken. För det tredje och kanske viktigaste; att åtgärderna skulle vara praktiskt och ekonomiskt möjliga att genomföra i Malmö. Vår förhoppning var att alla kommissionärer samt ordförande och sekretariat skulle utnyttja sina kontakter och nätverk för att få så gedigna kunskapsunderlag som möjligt. Här skulle kreativiteten komma att sättas på prov. Trots att högskolelagen rekommenderar alla forskare att redovisa forskningsresultat i form av avhandlingar, böcker, artiklar och i populärvetenskapliga sammanhang hade den processen tidigare varit trög (den s.k. tredje uppgiften; se ovan). Här fanns ett unikt tillfälle att visa att det skulle kunna fungera storskaligt. Totalt kom omkring 50 forskare att medverka till 32 underlagsrapporter. Alla trycktes, lades ut på nätet och började läsas och även omsättas praktiskt inom Malmö och intressant nog även inom andra delar av landet. De områden som vi täckte var:

- Hälsoförhållanden ur ett livsloppsperspektiv; mödrahälsovård, barn, elevhälsa, den vuxna befolkningens hälsa, de äldres hälsa, vårdkonsumtion

- Hur skall Malmö förstås; demografi, vad som gjorts tidigare

- Sambandet mellan arbete och hälsa, arbetsmiljö, arbetslöshet

- Utbildning med förskola, grundskola, gymnasieskola, fritidshem, komplementära skolor och faktorer som påverkar utbildningsstrukturer

- Den fysiska miljöns betydelse, segregation, socialt kapital, tillit och sammanhållning 
- Förståelse av samband mellan hälsa och hållbar utveckling, tillväxt och välfärd, demokrati och delaktighet

- Genus och hälsa

- Organisation, styrning, ledarskap, implementering

Intresset för att medverka i arbetet med att ta fram kunskapsunderlag växte överraskande snabbt, även inom forskarvärlden. Enskilda partigrupper och kommunalråd uppdaterades under resans gång. Vi involverade närmare 2000 personer från staden, civilsamhälle, näringsliv och lärosäten. Totalt arrangerades 28 seminarier och workshops på olika teman med olika målgrupper. Professor Marmot förlade ett EU möte inom hälsoområdet till Malmö där en eftermiddag ägnades åt Malmökommissionen och några viktiga frågor kunde diskuteras med olika experter. Vi byggde upp en hemsida, bloggade, gjorde lokala TV-program. Mediernas intresse var stort. Minst 80 artiklar med direkt anknytning till kommissionen publicerades under de två åren. Bland annat en helsida "debatt" i DN som fick stor uppmärksamhet och många kommentarer (DN 2012, 8). Marmot följde vårt arbete med stort intresse och besökte Malmö vid flera tillfällen. Han blev senare hedersdoktor vid Malmö högskola och ett par år senare även vid medicinska fakulteten vid Lunds universitet. Han medverkade även till att den till engelska översatta slutrapporten fick internationell spridning. Kommissionen hade sammanlagt 11 heldags- eller tvådagarsseminarier där intensiva diskussioner fördes om underlagen. Vid första mötet blev det skarpa diskussioner hur klokt det egentligen var att ha med både forskare och representanter för Malmö stad i kommissionen. Räckte det inte med forskare? Risken fanns för avhopp. Med argumentet att det behövdes både ett inifrån och utifrånperspektiv för att formulera konkreta rekommendationer ledde till att alla blev överens om att det var en bra sammansättning. Ofta gick diskussionens vågor höga. Med den erfarenhet jag själv har från den akademiska världen är jag imponerad och överraskad av det stora engagemang och kreativiteten kommissionärerna visade under hela processen. Ett bevis är kanske att alla var aktiva och stannade kvar ända fram till målsnöret den 1 mars 2013 då kommissionen lämnade ifrån sig slutrapporten: Malmös väg mot en hållbar framtid. Hälsa, välfärd och rättvisa för politisk beredning i kommunstyrelsen. Flera hundra kom till det avslutande seminariet i Moriska paviljongen, där professor Marmot plötsligt dök upp direkt från London (applåder). Han var imponerad. 


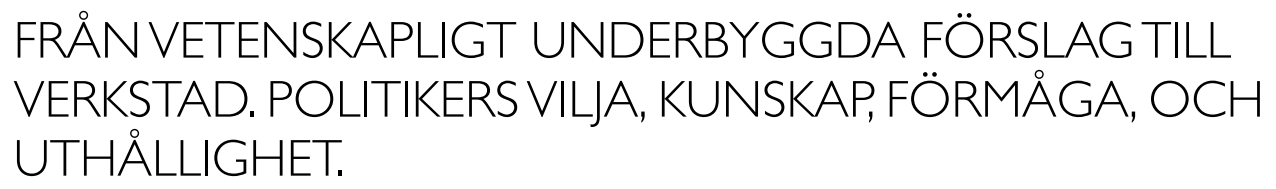

Malmökommissionens slutrapport Malmös väg mot en hållbar framtid. Hälsa, välfärd och rättvisa är ett unikt försök att tillämpa vetenskap storskaligt. Många tar kanske för givet att politiker fattar viktiga beslut på vetenskapliga grunder. Men hur ser verkligheten ut idag? Finns forskarnas synpunkter med i viktiga beslut? I september 2018 skriver företrädare för 61 forskningsorganisationer en debattartikel i Svenska Dagbladet med titeln "Var är forskningen i de politiska manifesten?". Bland undertecknarna fanns även rektorn för Malmö Universitet. I samtliga partiers manifest togs vikten av att grunda beslut på forskning endast upp ett fåtal gånger. Ord som fakta och evidens förekom inte alls. Undertecknarna som representerade hela det svenska forskarsamhället uppmanade den kommande regeringen att nya reformer bör ha stöd i tillgänglig forskning och uppmuntra forskare att samverka med det omgivande samhället (SvD 2018, 9). Det är nästan på kornet vad man gjorde i Malmö 2010 när man beslöt att ta fram ett vetenskapligt grundat förslag till hur ojämlikheterna i hälsa skulle kunna minskas i Malmö och som resulterade i slutrapporten 2013.

Hade politikerna omsatt förslagen till "verkstad"? Fanns det forskning som visade hur det skulle gå till? En av de 32 bakgrundsrapporterna som kommissionen tog fram hade titeln: Implementeringsforskning - en kunskapsöversikt (Löfgren 2013, 10). Området var märkligt nog ganska outforskat. Det var en myt att det fanns kunskap om hur politiska beslut skulle omsättas i verkstad. Nu handlade det framför allt om egen kunskap och eget omdöme hos politiker och tjänstemän. Mitt uppdrag var slut när slutrapporten lämnats till uppdragsgivaren Malmö stad. Men av eget intresse följde jag det fortsatta arbetet relativt intensivt första året, sedan mer sporadiskt. Min bedömning var och är att det var ett imponerande arbete som utförts under de gångna åren.

Först av allt inleddes en viktig del av den fortsatta processen; en remissrunda under sex månader. Nu var det tjänstemännens och politikernas tur. Hela 120 remissinstanser inom och utom kommunen bjöds in för att lämna synpunkter. Stadskontoret erbjöd sig att träffa remissinstanserna för att prata om kommissionens arbete och åtgärdsförslag. Även kommissionärerna deltog ibland i dessa möten. Flera av remissinstanserna bildade också olika former av arbetsgrupper. Den breda involveringen visade sig vara ett lyckat grepp. Remissvaren var överlag mycket välformulerade och välgrundade och visade på ett starkt engagemang från många håll, men också stora förväntningar på att det skulle bli "verkstad" av detta. Av remissvaren framgick även att många av kommissionens åtgärdsförslag redan var på gång att verkställas i olika förvaltningar. Stadskontoret som hade uppdraget att ta fram tjänsteskrivelsen till kommunstyrelsen bildade en intern analysgrupp. Stadskontorets samtliga avdelningar ingick i gruppen, hade möten och blev budbärare för frågorna inom den egna avdelningen (Renhammar 2014, 11). Den 5 mars 2014, ett år efter att slutrapporten lämnats till politikerna beslutade kommunstyrelsen om det fortsatta arbetet. Skulle snöbollen rulla vidare? 
För att kunna genomföra de förslag som man fattat beslut om, krävdes strukturella förändringar. Det ställer stora krav på organisationen på såväl tjänstemannanivå som på den politiska nivån. Kommunstyrelsen beslöt att avsätta särskilda medel för att påbörja ett trettiotal utredningsuppdrag som byggde på de 74 åtgärdsförslagen i slutrapporten. Varje utredning skulle rapporteras tillbaka till kommunstyrelsen eftersom en ny form av styrning och ett breddat deltagande i beslutsprocessen utgjorde kärnan i kommissionens budskap. Det var av vikt att utredningarna utfördes i samarbete med andra intressenter både inom och utom kommunen. Den kompetens som krävdes för att ta fram de 32 kunskapsunderlagen fanns med få undantag i Malmö eller Lund eller i huvudförfattarnas nätverk. Det är en viktig lärdom om man i framtiden tänker skapa kunskapsallianser som en solid grund för det fortsatta arbetet. Det var viktigt att ta fram aktuell kunskap om Malmöbornas hälsa, särskilt relaterat till sociala bestämningsfaktorer. Sedan decennier har forskning om Malmöbornas hälsa, dödsorsaker och sjukdomar intresserat forskare verksamma vid MAS. Den här kunskapen var givetvis avgörande för kommissionens arbete. Fanns det verkligen ojämlikheter i hälsa som kunde relateras till sociala bestämningsfaktorer? Hur såg verkligheten ut 2011? Nio av de 32 kunskapsunderlagen visade att det fortfarande förelåg betydande skillnader i hälsa relaterat till bland annat, utbildning, etnicitet, bostadsområde, inkomst, arbete $\mathrm{mm}$. Elva av de 32 underlagen var helt inriktade på barns och ungdomars hälsa och inte minst sociala bestämningsfaktorer av betydelse på lång och kort sikt för hälsa och livsvillkor. Enligt min mening var de åtgärder som riktades till barn och ungdomars livsvillkor de mest konkreta och praktiskt möjliga att genomföra.

Decennier av försök att kompensera för de faktorer som gör att man misslyckas i skolan visar att man med få, massmedialt uppmärksammade undantag, inte klarat av det. Sverige är inte något föredöme i en nationell jämförelse. I Malmö bidrar arbetslöshet hos föräldrar och boendesegregation, ofta i förening, till skolsegregationen. Man använder sig inte av de möjligheter som finns för att så tidigt som möjligt identifiera barn i gråzonen som löper mer risk att misslyckas längre fram (Kommission för ett socialt hållbart Malmö sid.158: 2013,1).

Den pågående utvärderingen skall vara klar i början av nästa år (2020). Viktigast av allt är rimligen att se om de välgrundade förslagen om insatser för barn och ungdomar har omsatts i verkstad. Har skolsegregationen minskat? Har ojämlikheterna i kunskaper mellan skolorna minskat? Har ojämlikheterna i hälsa minskat? Kommissionens uppdrag var att komma med vetenskapligt grundade förslag till hur ojämlikheterna i hälsa skulle kunna minskas i Malmö. Forskning som bedrivits under flera år i Malmö avseende hela livscykeln visar att livslängd och hälsa under hela livet bestäms till betydande del av sociala bestämningsfaktorer. Det är ingen tillfällighet att de som är välutbildade, har ett bra arbete, en bra inkomst och bra levnadsförhållanden är friskare och lever längre. Den avgörande frågan är hur samhället kan skapa förutsättningar för alla att det blir så. De socialt relaterade skillnaderna i hälsa som man ser i den äldre befolkningen kan ofta spåras tillbaka till barndomen (Kommission för ett socialt hållbart Malmö s. 33: 2013, 1). Malmökommissionens förslag till 
åtgärder gäller hela befolkningen men på sikt är det uppenbart att samhället får betala ett högt pris om man inte i tid identifierar individuella och strukturella orsaker till framtida ohälsa och utslagning redan tidigt i livet. Jag menar att kunskaperna om hur det skall göras finns. Malmöpolitikernas beslut att samla all tillgänglig kunskap är ett bra exempel. Frågan är om de nya politikerna i Malmö har förmågan att se helheten och bygga vidare på den grund som lagts och om det som redan gjorts hittills förändrat arbetssättet mot en mera hållbar utveckling. Utan att ha kunskaper om helheten och vad som påverkar barnen i det sociala nätverket, familjen, skolan, närområdet och samhället i stort är det svårt att veta vad som haft störst effekt.

Tanken bakom det som redan gjorts i Malmökommissionens anda är bland annat att resultaten skall användas som hävstång för att omsätta FN:s 17 globala mål för ett hållbart Malmö (ekonomiskt, ekologiskt och socialt). Agenda 2030 och de 17 globala målen för hållbar utveckling är en detaljerad agenda som antogs av FN:s alla medlemsstater i september 2015. Regeringen antog i juni 2018 en handlingsplan för hur Sverige skall uppnå FN:s globala mål för en hållbar utveckling till 2030. Handlingsplanen för de närmaste åren togs fram av en delegation tillsatt av regeringen. Den leds av generaldirektören för Formas, ett forskningsråd som finansierar forskning av högsta vetenskapliga kvalitet bland annat inom området samhällsbyggande. Delegationen består av 11 medlemmar varav tre är välkända forskare, sex från näringsliv och arbetsliv samt två är politiker. Den ena politikern är nuvarande ordförande i kommunstyrelsen i Malmö och som också var ansvarig för Malmökommissionens tillsättning och fortsatta arbete. Det är intressant att följa Malmö stads långsiktiga arbete med Agenda 2030 som bedrivs under kommunstyrelsen med samma ordförande. Inte minst eftersom den har beslutat att detta arbete ska innefatta fortsatta sociala investeringar i enlighet med Malmökommissionens rekommendationer.

Titeln på den pågående utvärderingen av Malmökommissionen är: "Det fortsatta arbetet för ett socialt hållbart Malmö-med Malmökommissionen som hävstång. Det skall bli intressant att se om de sociala bestämningsfaktorerna för hälsan påverkats och framför allt: har de aktörer som skulle medverka till att genomföra åtgärderna ändrat sitt arbetssätt och i så fall hur. Har man prioriterat åtgärder riktade mot barn och ungdomar? Har samarbetet med akademi och forskare intensifierats? Har nya kunskapsallianser skapats? Under flera decennier har jag medverkat i genomförandet av stora befolkningsprojekt inom och utom Sverige. Jag är medveten om komplexiteten när det gäller att utvärdera vad som är orsak och verkan. Att redan efter fem år förvänta sig att dödlighet eller hälsan skulle påverkats är orealistiskt. Vad jag redan vet är att flera förvaltningar ändrat sitt arbetssätt med större förståelse för betydelsen av vetenskapliga grunder för viktiga beslut. Ett socialt hållbart samhälle är nödvändigt vid sidan om ekologisk och ekonomisk hållbarhet. Malmö har utan tvekan visat vägen. Om man dessutom slutar med att skjuta vilt omkring sig i "Sveriges Chicago" kanske den mörka bilden av Malmö blir en annan. Den som lever får se!

Var Malmökommissionen värt pengarna? Den totala kostnaden för kommissionen under två år var drygt sex miljoner (forskare, kansli, seminarier mm). Ett par 
jämförelser. En förstudie om behovet av spårvagnar i Skåne lär ha kostat omkring 30 miljoner (Balkfors 2014, 12). Sjukvårdsbudgeten i Region Skåne 2019 uppgår till 36,3 miljarder kronor (Region Skåne 2019, 13). Även förebyggande insatser måste få kosta.

\section{BARNS OCH UNGAS LEVNADSVILLKOR}

Den här antologin har sitt fokus på barn och unga i Malmö. Utgående från direktivet till kommissionen skulle en av de tre prioriteringarna i vårt arbete vara barn och unga. Så blev det också. Kommissionärerna var alla medvetna om att en god start i livet är en av de absolut viktigaste faktorerna för ett långt liv med god hälsa och gott välbefinnande (Stigendal och Östergren 2013, 14). Vuxna människors beteende är svårare att påverka (Jfr Greta Thunberg). Det är "svårt att lära gamla hundar att sitta". Men under kommissionsarbetets gång visade det sig att det i stort sett saknades möjligheter att med hjälp av sociala bestämningsfaktorer systematiskt beskriva jämlikhetssituationen i Malmö avseende barns och ungas hälsa på det sätt som under många år gjorts för vuxna. Det fanns alltså inga tillförlitliga studier som visade hur våra ungdomar mår. Det som fanns var enkätundersökningar vart tredje år i årskurserna 6, 9 och andra året i gymnasiet av malmöelevers levnadsvanor. Region Skåne genomförde under våren 2012 en enkätundersökning riktad till skolungdomar där möjligheter fanns att på kommunal nivå analysera sociala skillnader i upplevd hälsa och levnadsvillkor (Region Skåne 2012, 15). För övrigt fanns möjligheter att beskriva skillnader i barns och ungas hälsa mellan barnavårdscentraler, tandvårdskliniker, skolor och bostadsområden. Det mest omfattande arbetet blev att samla den kunskap som fanns samt ta fram ny kunskap om barns och ungas levnadsvillkor i Malmö. Av de 32 kunskapsunderlagen utgjordes inte mindre än nio av barns och ungas uppväxtvillkor och två av basdata om hälsan. En uttalad social ojämlikhet i hälsa kunde påvisas. Ett exempel är tandhälsan bland 6-åringar som på ett utmärkt sätt speglar den sociala miljöns betydelse för ett mätbart hälsoproblem. Behovet av tandlagning varierade mellan cirka 10 ända upp till knappt 60 procent beroende på var barnen bodde.

De systematiska skillnaderna i hälsa som påvisades hos Malmöbarnen hade samband med de sociala bestämningsfaktorerna som utgjordes av deras konkreta levnadsvillkor. Exempelvis sociala relationer och möjligheter till emotionell och kognitiv stimulans, bostadens och bostadsområdets kvalitet och möjligheterna till en trygg och stimulerande förskola, skola och fritid. Medan internationell och nationell forskning visade att det hänt väldigt mycket när det gäller undervisningskvalitet visade samma källor att Sverige rörde sig i motsatt riktning. Malmö var inget undantag. I relation till målet om en likvärdig skola där alla elever skall ges samma möjligheter att klara skolan utgående från sina egna förutsättningar gick det åt fel håll. De nio underlagsrapporterna som kommissionen tog fram inom området "Barn och ungas uppväxt" 
var förankrade i svensk och internationell forskning. Vi redovisade forskning som belyste vikten av tidiga insatser i förskolan, den socioekonomiska bakgrundens betydelse för elevers skolprestationer, ankomst till Sverige efter ordinarie skolstart och boendesegregation. Vi beskrev utbildningspolitiska reformer, som till exempel valfriheten, förskolornas och skolornas potential och lokala organisering, avhopp från gymnasiet, fritidshemmens utmaning, alternativa skolformer, samverkan med föräldrar samt kvaliteten i pedagogiska modeller för arbete med barn som inte har svenska som modersmål. Det var delvis unik, tillförlitlig och nödvändig kunskap. Vi föreslog väl underbyggda och praktiskt och ekonomiskt försvarbara åtgärder för att på kort och lång sikt påverka sociala bestämningsfaktorer för hälsan: bland annat halvera barnfattigdomen, minska hemlöshet, trångboddhet, dåliga bostadsförhållanden, inventera resursbehov i stadens utbildningsinstitutioner, åtgärder för att inga barn skulle stå utanför förskoleverksamheten, tidig och kontinuerlig uppföljning av studieresultat, inrätta minst en heltidstjänst med ansvar för fritidshem, reformera systemet för mottagandet av nyanlända elever, åtgärder för en bättre integrerad elevsammansättning avseende socioekonomiska, etniska, könsmässiga och prestationsmässiga kategorier. Förslag till hur åtgärderna skulle genomföras i Malmö redovisades i detalj. Det var omöjligt att täcka allt på den begränsade tid vi hade till förfogande. Ett viktigt område som ej hanns med var barn och ungdomar med funktionsnedsättning.

Inför en föreläsning jag höll 2017 för ledande tjänstemän framför allt inom socialtjänst i Skåne men även med representanter från BUP och barnhälsovård intervjuade jag några chefer från Malmö. Seminariets tema var: "Vi måste börja med barnen " och hade sitt fokus på hur skyddet för barn och unga i riskmiljöer skulle kunna stärkas. Jag kände sedan mitt arbete med Malmökommissionen nästan alla som jag intervjuade. Det blev bra samtal. De intervjuade cheferna hade det yttersta ansvaret för förskola, grundskola, socialtjänst, elevhälsa, barnhälsovård och BUP (ansvarig specialistsjuksköterska första linjen). Jag fick en tydlig bild av att inom alla dessa områden gjordes mycket bra, professionella insatser. Utan tvekan och med rätta fanns det en stolthet över de insatser som gjordes för Malmös barn och unga. Men en sak var tydlig. I regel gjordes inga gemensamma insatser förrän något som inte borde ha hänt redan inträffat. Det fanns ingen tydlig bild av hur den egna målgruppen såg ut. Behovet av insatser från BUP är mycket stort och resurser till BUP prioriteras av politikerna. Det fanns däremot en tydlig bild av att resursstarka föräldrar sökte hjälp och stöd för sina barn i större utsträckning än föräldrar från resurssvaga områden i staden. Trots att målbilden ofta borde vara densamma arbetade var och en i sina stuprör. Alla intygade också att det inte var resursbrist som gjorde att det inte gick att sätta av tid för att arbeta mer förebyggande.

Det går aldrig att vara ute för tidigt när det gäller att förebygga att ett barn som far illa inte riskerar att misslyckas med sitt liv. Målbilden bör vara gemensam för alla aktörer. Av integritetsskäl får kunskaper om barn i förskolan inte följa med till förskoleklass (förskoleklass skall nu finnas enligt lag). Chefen för socialtjänsten berättade att ofta är många aktörer inblandade när det börjar gå snett för ett barn eller en ungdom. I något enstaka fall hade upp till 20 professionella personer arbetat med ett 
och samma barn. Två forskningsområden som jag bedömer som mycket angelägna ur ett barnperspektiv är möjligheter till aktiva insatser i ett tidigare skede än nu samt modeller som visar hur man kan riva stuprören mellan alla aktörer som gör ett proffsigt jobb men kanske för sent. Kerstin Bergman från SKL (Sveriges Kommuner och Landsting) har under många år arbetat med barn och ungdomsfrågor och sammanfattar sina synpunkter i följande meningar:

Det är dags att vi tänker om även i vårt land. Det behövs lägre trösklar till effektiv hjälp, vilket inte verkar underlättas, av en barnavårdsutredning efter anmälan. Lagstiftningen behöver ändras så att det går att ge tidiga insatser, som så kallad service, INNAN anmälan och utredning. Vi behöver lämna skrivborden och möta barnen och föräldrarna där de är: I skolan eller i bostadsområdet (SKL 2015, 16).

\section{VART BÄR DET AV?}

Har Malmö visat vägen? Utan tvekan har Malmökommissionens sätt att arbeta och slutrapporten satt djupa och sannolikt bestående spår i sättet att arbeta både lokalt, nationellt och kanske även internationellt. Det är ingen Turning Torso, ingen Öresundsbro eller Citytunnel, som är synliga tecken på ekonomisk tillväxt och hållbarhet. Men Malmö har även uppmärksammats internationellt för sitt miljöarbete, den ekologiska hållbarheten. Och nu även när det gäller social hållbarhet.

Malmökommissionen är ett unikt exempel på att politiker visat vägen hur forskare och praktiker tillsammans försökt bryta utvecklingen mot ett alltmer ojämlikt samhälle med betydande skillnader i hälsa. Ett samhälle som inte bara är ekonomiskt och ekologiskt hållbart utan även socialt. Det finns en humanitär tyngd i detta arbete. Den uppmärksammas inte lika mycket som tillväxtsymbolerna. På lång sikt blir det kanske avgörande för ett samhälle med tillit till politiken.

Även om utvärderingen efter de första fem åren inte är klar hoppas jag min subjektiva redovisning av tillkomsten av Malmökommissionen och slutrapporten kan vara intressant för läsaren. När den pågående utvärderingen är klar kanske något resultat får sin förklaring av något i min text som inte finns någon annan stans. Min övertygelse är att de beslut som politikerna nyligen har fattat om att använda erfarenheterna av Malmökommissionens sätt att arbeta som hävstång för ett fortsatt långsiktigt arbete för en hållbar stad är klokt. Det är arbetssättet med förankring i vetenskap, samarbete mellan politiker, forskare och med en bred förankring i samhället man skall slå vakt om. Det bör integreras som en självklar del i arbetet med ett hållbart, tryggt och säkert samhälle. En kontinuerlig monotorering av de sociala bestämningsfaktorerna för livskvalitet, hälsa och trygghet måste vara vägledande för kunskap om hur ett socialt, ekologiskt och ekonomiskt hållbart Malmö skall uppnås och bibehållas. 
För mig personligen har resan med Malmökommissionen varit lärorik, stimulerande och meningsfull.

Jag hoppas resan fortsätter med gamla och nya passagerare och med påfyllnad av ny kunskap, nya idéer och förnybar energi under många år. För det krävs kunniga, omdömesgilla ledare och en befolkning som fătt bästa tänkbara start i livet. Vi måste börja med barnen! Välfärdssamhällets överlevnad hänger på att alla kan stå på egna ben. Om någon av förklarliga skäl inte klarar det skall vi ha resurser att kompensera för fysisk, psykisk och social funktionssvikt som alltid kommer att finnas. Omfattningen i framtiden avgör vi nu.

Nog finns det mål och mening $i$ vår färd

Men det är vägen som är mödan värd

Karin Boye $(1927,17)$

\section{REFERENSER}

1.Malmös väg mot en hållbar framtid. Hälsa, välfärd och rättvisa. Kommission för ett social hållbart Malmö (2013), [Red:] Stigendal M. \& Östergren P-O, Malmö stad.

2. Closing the gap in a generation: health equity through action on the social determinants of health. Final report of the commission on the Social Determinants of Health (2008), World Health Organisation (WHO).

3. Svenska lärdomar av Marmotkommissionens rapport Closing the gap. (2013).

Statens folkhälsoinstitut: http:www.fhi.se/Om-oss/Uppdrag-och-styrdokument/ Regeringsuppdrag/Redovisade-uppdrag/Marmot/.

4. Nästa steg på vägen mot en mer jämlik hälsa. Förslag för ett långsiktigt arbete för en god och jämlik hälsa (2017). Slutbetänkande av Kommissionen för jämlik hälsa. SOU 2017:47.

5.Folkhälsorapport-Malmö kommun (1991). [Red:] Nilsson Å, Hansson BS och Isacsson S-O. Socialmedicinska avdelningen/Institutionen för klinisk samhällsmedicin.

6.Lag 2009:45.

7.Från Lazarett till Universitetssjukhus. En hundraårskrönika om Universitetssjukhuset MAS (1996), [Red:] Ersgård S.

8.Dagens Nyheter, 2012-02-12.

9.Svenska dagbladet, 2018-09-09. 
10.Löfgren K., Implementeringsforskning - en kunskapsöversikt. Underlagsrapport 31, refererad till i Malmös väg mot en hållbar framtid. Hälsa, välfärd och rättvisa. [Red:] Stigendal M. \& Östergren P-O, (2013) Malmö stad 2013.

11.Renhammar E. "Det fortsatta arbetet för ett social hållbart Malmö". Socialmedicinsk tidskrift 2014: 5.

12.Balkfors A., "Malmökommissionens arbete från initiativ till slutrapport." Socialmedicinsk tidskrift 2014:5.

13.Region Skåne. Budget 2019.

14.Barn och ungas levnadsvillkor. I: Kommission för ett socialt hållbart Malmö. Malmös väg mot en hållbar framtid. Hälsa, välfärd och rättvisa (2013). [Red:] Stigendal M. \& Östergren P-O. Malmö stad.

15.Folkhälsorapport Barn och Unga i Skåne (2012). Region Skåne: https://www. skane.se/siteassets/.../folkhalsorapport_barn_och_unga_2012.pdf

16.Bergman K. Inledningsföredrag vid konferensen: Stärkt skydd för barn och unga. Referera till Sveriges kommuner och landsting Rapport best.nr 5395. 2015.

17.Boye K. (1927) "I rörelse", Härdarna. 


\title{
Ungdomsproblem i "utsatta områden": Komplexa orsaksförklaringar och reduktionis- tiska lösningar
}

\author{
Vanja Lozic
}

Våren 2019 presenterade Malmöliberalerna ett förslag på ett så kallat "förväntansdokument (ansvarskontrakt)" som skulle skickas till samtliga vårdnadshavare till elever i Malmös grundskolor för att skrivas under. Liberalernas Sara Wettergren, ordförande i grundskolenämnden, förklarade i sin problematisering av skola och samhälle att:

Ordning och studiero är två stora utmaningar i klassrummen idag. Det kan tyckas elementärt att påminna om att barnen ska komma mätta och utvilade till skolan, men faktum är att många lärare vittnar om att bristfälliga mat- och sovvanor påverkar undervisningen. Förväntansdokumentet innehåller ett antal enkla men tydliga punkter om vad som kan anses ingå i föräldraskapet, vad som ligger i skolans uppdrag, och vad eleven själv behöver tänka på (Liberalerna 2019).

Enligt medierna är förslagets huvudsyfte "att föräldrar ska se sin skyldighet att aktivt delta i sitt barns lärande och skolgång" och att de också ska "skriva under på att ha ett positivt förhållningssätt och visa förtroende för skolan" (SVT 2019, SR 2019). Problematiseringarna kan ses som exempel på de sätt föräldrar betraktas som både en orsak till skol- och ungdomsproblem och en potentiell lösning.

Carol Bacchi (2010) menar att politiker, experter och tjänstemän (t.ex. polisen, socionomer, lärare, psykologer, socialarbetare, journalister osv.) styrs i sitt arbete av problematiseringar. Genom problematiseringar (vad och vem som kategoriseras som problem) riktar olika yrkeskategorier sitt intresse mot för dem viktiga problemområden och grupper. Problematiseringar påverkar även vilka lösningar/åtgärder som efterfrågas och initieras. Samtidigt är det viktigt att understryka att problembilder/ problematiseringar av olika individer, grupper och stadsdelar och andra sociala rum liksom orsaksförklaringar och de professionellas arbetssätt och lösningar är inte "naturgivna" och "oföränderliga". De är snarare historiska produkter av i samhället dominerande föreställningar, normer och maktordningar samt yrkesgruppers olika arbetskulturer och människosyner (Rose 1999). I följande kapitel analyseras de sätt representanter för socialtjänst, polis, skola, offentlig sektor och frivilligorganisationer problematiserar orsaker till ungdomsproblem i ett så kallat utsatt område (nedan kallat 
Sandberg). ${ }^{1}$ Beskrivningar av orsaksförklaringar kopplas sedan till åtgärder som anses vara eftersträvansvärda och som de intervjuade yrkesutövarna efterfrågade, initierade och/eller implementerade under perioden 2014-2017.

\section{VAD ANSES VARA PROBLEMET?}

Det urbana rummet som beskrivs i detta kapitel har i medier och i andra sammanhang benämnts som "förortsområde", "utanförskapsområde", "invandrartätt område", "miljonprogramsområde" och "invandrarförort". Enligt polisen kännetecknas områden som dessa av våld, upplopp, narkotikahandel och annan allvarlig brottslighet:

Ett utsatt område är ett geografiskt avgränsat område som karaktäriseras av låg socioekonomisk status och kriminell påverkan på lokalsamhället. Ett utsatt område uppvisar en problematik som primärt kräver polisiär närvaro och polisiära insatser för att komma till rätta med existerande problem (Polisen 2015, 4).

Centrala aktörer i skapandet av otrygghet och försvagning av rättssäkerhet anses vara problematiserade ungdomar och unga vuxna, som enligt polisen tar lagen i egna händer och försvårar polisiärt arbete och sprider otrygghet bland lokalbefolkningen. Bilden som träder fram i polisens, politikers och mediers skildringar är att här råder öppna konflikter mellan kriminella grupperingar och fientligt agerande mot polis och andra representanter för samhället. Särskilt utsatta områden kännetecknas vid sidan om dessa och likande problem även av "våldsbejakande religiös extremism" och befolkningens obenägenhet att delta i rättsprocesser. Innan jag går vidare med att synliggöra problematiseringar av ett sådant område, nämligen Sandberg, låt mig först poängtera att problematiseringar av vissa grupper, individer och områden ingalunda är nya företeelser, utan har en lång historia.

I Det empiriska materialet består av intervjuer med 19 representanter för blåljusmyndigheter, frivilligorganisationer, kommunanställda samt fältobservationer från samverkansprocesser. Det är socionomers, rektorers, blåljusmyndigheter, psykologers, dramapedagogers, ungdomscoachers, projektledares och områdessamordnare som intervjuats under 2014 och 20 I 5 . Fältstudierna genomfördes under perioden 2014-2017. Samtliga namn på personer och platser är anonymiserade. 


\section{OBJEKT FÖR PROBLEMATISERINGAR FÖRÄNDRAS ÖVERTID}

Medan problematiseringar av 'utsatta områden' företrädelsevis tar avstamp i problematiseringar av arbetslöshet, invandrarskap och det mångkulturella samhällets utmaningar tycks 1800 -talets problembeskrivningar ha handlat om bl.a. sociala problem till följd av den stora befolkningsökningen, hoten från religiösa sammankomster utanför stadskyrkan, konflikter på arbetsmarknaden, utvandring, osv. Medan etnicitet och invandring står i fokus för samtida problematiseringar spelade vid sekelskiftet 1900 klassperspektivet och genusfrågor en central roll i problematiseringar av samhället. I linje med detta tilläts inte elever med välsituerade föräldrar att "gå i samma klass som elever till arbetslösa ensamstående mödrar" (Sjögren 2010, 201). Under 1900-talets första hälft kategoriserades och särskiljdes individer och grupper utifrån biologistiska och rasistiska föreställningar. Romani och tattare var de två grupper som samhällets maktstrukturer riktade särskilt sökljus mot eftersom de ansågs vara avvikande och deras levnadssätt, kultur och barnuppfostran bedömdes vara ett hot mot rådande samhällsordning (Sjögren 2010). Huvudargumentet för särartspolitik, dikotomisering, kategorisering och stereotypisering var synen att "olika raser hade vissa naturliga anlag, vilket gjorde att det fanns naturgivna skillnader i kognitiva förmågor mellan olika raser" (Sjögren 2010, 201).

I samtida problematiseringar av områden som liknar Sandberg har begreppet segregation haft en central betydelse. Mikael Stigendal (1999) särskiljer mellan rums-, demografi-, struktur-, kultur-, resurs- och maktsegregation och konstaterar att segregationen kan leda till framväxten av nya subsamhällen, vilka på sikt kan bli ett hot mot samhällets rådande normsystem och strukturer. Magnus Dahlstedt (2015) framhåller att sedan mitten av 2000-talet har två begrepp dominerat den politiska debatten om segregation och framväxt av så kallade parallella samhällen eller subsamhällen. De är utanförskap och utanförskapsområden. Dahlstedt menar att dessa och likdanande begrepp har en stigmatiserande och skuldbeläggande funktion och att de utgör en förståelsehorisont, varigenom "mångetniska" stadsmiljöer och dess befolkning får representera "utanförskapets kultur", social oro, invandringsproblem, arbetslöshet och integrationsproblem. Dessa och liknande kategoriseringar konstruerar vissa människor och geografiska områden som motpoler till det "normala" eller som ett objekt för åtgärder (Brune 2004). De idémässiga mönstren, vilka genomsyras av diskurser som skuldbelägger och stereotypiserar dessa områden och de boende, är inte nya utan går tillbaka till 1970-talet.

Under 1970-talet handlade problematiseringar företrädelsevis om de boendes arbetarklassbakgrund och låga utbildningsnivå (Ristilammi 1999; Arnstberg 2000). Sedan 1980-talet har problembilder dominerats av migrationstematik, kulturskillnader samt socioekonomisk och etnisk segregation. Undermåliga och eftersatta bostäder byggda under miljonprogrammets storhetstid, (ung) befolkning med låg sysselsättningsgrad och utbildningsnivå, hög andel invånare födda utanför Sverige, kulturskillnader och 
låg genomsnittlig disponibel inkomst. Dessa, tillsammans med bilder av våldsamma ungdomar, fungerar sedan millennieskiftet som centrala tolkningsramar i beskrivningar av områden i allmänhet och ungdomars livssituation i synnerhet (Dahlstedt 2015; Nordström Skans \& Åslund 2010).

Därutöver har omvandlingen av välfärdsstatens roll sedan 1980-talets slut varit en viktig förklaringsmodell för ökad segregation, ökade sociala problem och oroligheter. I grova drag handlar samhällsomvandlingen om neoliberal styrningsmodell, som kännetecknas av skiftet från centraliserade lösningar, en Keynesinspirerad ekonomisk modell och statlig styrning, till valfrihetsdiskurser, minskad jämlikhet i skolan, nedskärningar i de offentliga utgifterna och ökad avreglering (Korpi \& Palme 2003; Skolverket 2009; Bunar 2010). Problemdiskurser innefattar även en förskjutning av ansvaret från staten till frivilligsektor och medborgare (Dahlstedt \& Hertzberg 2011; Kings 2011; Velásquez 2005). De senaste decenniernas samhällsomvandlingar framstår som viktiga orsaksförklaringar till minskad likvärdighet i skolan, social utslagning, ökad barnfattigdom, segregation och misstro mot samhället och dess institutioner samt ökade sociala skillnader och oroligheter (Kamali 2006; Magnusson 2014).

Samhällsomvandlingar och ansvarsförskjutning har inneburit att samverkansprocesser mellan privata, statliga och kommunala organisationer samt frivilligorganisationer har fått en ökad betydelse i bekämpning och prevention av ungdomsproblem (Dahlstedt och Hertzberg 2011). Förespråkare av samverkan hävdar att bristande samverkan leder till fragmenterade och ineffektiva insatser som inte tar hänsyn till den lokala kontexten eller människors egna önskningar och behov (Nordström Skans \& Åslund 2010; Schierup, Ålund och Kings 2014). Målet med samverkan tycks vara effektivisering, helhetsperspektiv och ökad delaktighet i och demokratisering av åtgärdsinsatser (Lozic 2018). Genom samverkan mellan exempelvis skolan, arbetsmarknadsparterna, civilsamhället och andra aktörer hoppas man kunna minska risken för framväxt av ungdomsproblem. Kritikerna menar däremot att samverkansprocesserna står som symbol för en förskjutning av ansvaret från staten till frivilligsektor och medborgare samt en aktiveringspolitik som syftar till att rusta dem så att de kan vara delaktiga och självständiga (Dahlstedt och Hertzberg 2011). Efter denna korta kontextualisering ska jag i det följande beskriva hur Sandbergs sociala problem i allmänhet och ungdomars liv i synnerhet tolkas av de intervjuade.

\section{Segregationen syns i byggnadernas tillstånd}

Segregation är en central tolkningsram genom vilken Sandbergs ungdomars framtidsmöjligheter tolkas. Sandberg beskrivs av yrkesverksamma på fältet som ett socioekonomiskt, utbildningsmässigt och på andra sätt segregerat område, något som leder till att människor bosatta där inte möter människor med andra erfarenheter och bakgrunder, inte minst människor utanför området dvs. människor som anses representera samhällsnormen och innanförskapet. Två tecken på segregation anses vara särskilt betydelsefulla enligt de intervjuade. Det handlar om hög koncentration 
av invandrad och arbetslös befolkning liksom bostadsbeståndens skick och skolornas kvalitet. Låt mig först diskutera bostadssituationen och skolan.

En dominerande syn är att skillnaden i boendekvalitén och bristande likvärdighet när det gäller skolan ökar risker för att ungdomarna ska hamna i problem och söka sig till, ur majoritetssamhällets synvinkel, problematiska livsval och försörjningsformer. Medan ungdomscoachen Karl kategoriserar fastighetsbeståndet i Sandberg som närmast katastrofalt, kritiserar kommunrepresentanterna, Nicklas och Olivia, fastighetsägarna för spekulationsartat och kortsiktigt ägande och bristande ansvarstagande. Blåljusrepresentanten Patriks erfarenheter talar sitt tydliga språk. ${ }^{2}$

De fastigheter som folk bodde i har inte renoverats på 20-30 år - så man bodde riktigt dåligt. När man kom dit så trodde man inte att det var Sverige! Alltså, allting var så nedfallet. En av våra arbetsuppgifter är att göra hembesök /.../. Men [våra insatser för ökad trygghet och säkerhet] är det minst relevanta problemet folk har att oroa sig för! De hade inte dörrkarmar, det fanns håll i väggar, allting var slitet! På vissa dörrar, när du stängde dem, så var det en sådan glapp på dörren och sen ska vi komma [med våra informationskampanjer], förstå du!

Det centrala här är att blåljusmyndighetens arbete för ökad trygghet och säkerhet förefaller, i förhållande till bostadsförvaltningen, vara en ytterst perifer angelägenhet för de boende.

Medan utbildningsinstitutioner och fritidsaktiviteter framställs som viktiga skyddsfaktorer, visar både kommunal statistik och samtal med olika yrkesgrupper att dessa institutioner tycks ha stora likvärdighetsproblem. Exempelvis påpekar en tidigare rektor Henrik, att skolresultaten har varit mycket dåliga och att skolans byggnader har varit i "fruktansvärt" skick. Den fysiska skolmiljön har karakteriserats av "klotter, skadegörelse, förstörelse, närgånget, skitigt, äckligt!". Om skolan hade varit placerad i en mer välbärgad stadsdel hade den stängts med omedelbar verkan, menar rektorn. Även om den svenska skolans negativa utveckling skildras som ett nationellt problem som har pågått under en längre tid, har den negativa utvecklingen accelererat sedan millennieskiftet och särskilt drabbat områden och kommuner med större andel socioekonomiskt utsatt befolkning.

Det svenska skolsystemet var i början av 1990-talet ett av världens mest jämlika och var världsledande på att kompensera för föräldrarnas utbildningsbakgrund (Håkansson och Sundberg 2012). Dock har skolsegregationen, framförallt mellan elever med så kallad utländsk och svensk bakgrund, ökat sedan början av 1990-talet och skillnaderna mellan olika skolor är idag mycket stora (Böhlmark et al. 2015). Ökningen av skolsegregationen sammanfaller i tid med framväxande boendesegregationen, och forskningen visar på att det finns starka samband mellan ökad skolsegregation och ökad boendesegregation. Som en följd av bland annat den ekonomiska krisen på 1990-talet ökade bostadssegregationen (Skolverket 2009). Elever med likartad social

2 I anonymiseringssyfte används generella termer såsom "'blåljusmyndighet", "'kommunrepresentant" och "ungdomscoach" och inga namn på myndigheter och organisationer de representerar anges. 
och utbildningsmässig bakgrund samlades på samma skolor. Ann Rodenstedt (2014) påpekar att en stark bidragande orsak till ökad segregation är medelklassens koncentrering till vissa stadsområden och deras föreställning om, stereotypisering av och distansering från vissa, ofta invandrartäta, stadsområden vilka betraktas som farliga och osäkra. Medelklassen har i ökad utsträckning sökt sig till avskilda och avgränsade stadsdelar och ibland till så kallade grindsamhällen (områden med stängsel och låsta grindar som ska skydda de boende från problem i det omgivande samhället).

Sedan friskolereformen i början av 1990-talet har dessutom vissa föräldragrupper i ökad utsträckning gjort aktiva val att flytta sina barn från skolor i socioekonomiskt utsatta områden till andra skolor med mål att skapa bättre framtidsmöjligheter för sina barn. Konkurrensen på skolmarknaden och det fria skolvalet har lett "till en ökad segregation utifrån ett socioekonomiskt, etniskt och prestationsmässigt perspektiv som en följd av att olika grupper i samhället förhåller sig till och använder sig av möjligheten att välja skola på olika sätt" (Kallstenius 2010,220). Således har resultatskillnader mellan skolor och elevgrupper ökat och i dag har föräldrars utbildningsnivå större betydelse för barns skolresultat än tidigare (Håkansson och Sundberg, 2012). Problematiken anses vara särskilt framträdande i Sandberg:

Rektor Henrik: Många elever från Sandberg gick på skolor i andra stadsdelar i hela staden, det kom bussar och hämtade eleverna. Jag tror att en tredjedel av Sandbergs elever gick i skolor utanför Sandberg, medvetna val av föräldrar som kan välja. De gjorde valet att ta barnen från Sandberg och de som blev kvar var de allra mest resurssvaga elever.

Därmed har den positiva kamrateffekten i de utsatta miljöerna minskat - en påverkansfaktor som enligt utbildningsvetaren John Hattie (2009) är bland de mest centrala för hur väl elever ska lyckas i skolan.

Vid sidan av försämrade skolresultat, negativ kamrateffekt och förflyttning av eleverna till andra stadsdelar så pekas hot och våld ut som ständigt återkommande problem i skolan. En av de intervjuade rektorerna berättar om ständiga polisuttryckningar i skolan och att verksamheten när som helst kunde avbrytas på grund av slagsmål och gängkonflikter. Samtidigt som skolorna i de "särskilt utsatta" områdena blir en sinnebild för problem visar forskningen att stereotypiseringar påverkar lärarnas syn på elever, vilket i de "utsatta områden" oftast innebär att det kan vara svårt att rekrytera nya lärare och att anställda lärare har förhållandevis låga förväntningar på eleverna (jfr. Isling Poromaa 2016). Att öka lärarnas förväntningar på elever är något rektorn Carina har haft i fokus i sitt pedagogiska utvecklingsarbete, menar hon. Segregationen och den påstådda koncentrationen av problemen kopplas inte enbart till negativa förväntningar utan även framtidsmöjligheter och avsaknad av positiva förebilder. 


\section{Positiva framtidsvisioner och förebilder saknas}

Arbetslöshet, kriminalitet och brist på positiva förebilder är en återkommande referensram när de olika yrkesutövarna diskuterar orsaker till ungdomsproblem i Sandberg. Socionomen Olivia menar till exempel att arbetslöshet har blivit "det normala" i 'utsatta områden', vilket implicerar att "ingen man känner går till jobbet". Problemet är enligt henne så omfattande att barn och ungdomar på frågan "Vad ska du bli när du blir stor?" svarar "Jag ska bli ingenting". Situationen innebär, menar hon, att de arbetslösa "blir förebilder för barnen" och att problemet förs från generation till generation.

I 'utanförskapsområden' tycks alltså råda helt andra villkor än i resten av samhället, och förekomsten av kriminalitet är ett talande exempel på de sätt områden kontrasteras mot resten av Sverige och andra stadsdelar. Poliserna Andreas, Ingvar och Jesper framhåller att även om de kriminella är i myndighetens ögon negativa förebilder, erbjuder de vissa unga män en väg ut ur fattigdom, de erbjuder status, trygghet och gemenskap. Det faktum att en hög andel av de boende är födda utanför Sverige beskrivs ofta som en central förklaring och orsak till avvikande beteende och kriminalitet, en problematisering som jag i det följande ska fördjupa mig i.

I de intervjuades beskrivningar kopplas en hög koncentration av invandrare i områdena till isolering från majoritetssamhället och förekomsten av "samhället i samhället", där egna lagar, regler och normer gäller. I sitt resonemang om parallella samhällen framhåller en ungdomscoach, som jag kallar för Maria, att föräldrar ofta lever i "små communities" och inte har "lärt sig [det svenska] språket", är engagerade i så kallade etniska föreningar och får samhällsinformation främst från utländska tv-kanaler. Varningar för att föräldrarna "klarar sig i en egen verklighet", vilken avviker från majoritetssamhället, och synen att barn och ungdomar påverkas negativt av att föräldrarna "är väldigt utanför resten av landet", såsom ungdomscoachen utrycker det, är ytterligare exempel på sådana problematiseringar. Några representanter ser även stora risker $i$ att ungdomar som är födda och uppvuxna i Sverige inte känner solidaritet och samhörighet med det svenska samhället, och dessutom känner ett hat mot majoritetssamhället och dess institutioner.

\section{Hemmets destruktiva inverkan}

De intervjuade framhåller ofta att problematiska familjeförhållanden, våld i skolan och på gatan hänger ihop och att åtgärderna behöver baseras på helhetstänkande och samverkan mellan olika organisationer och personer, inte minst föräldrarna. I "dysfunktionella" och "spruckna" familjer, där föräldrarnas engagemang och ansvar uteblir, som man uttrycker det i intervjumaterialet, känner sig barnen "ensamma, rädda och övergivna". Flera intervjuade menar att en konsekvens av svåra hemförhållanden och avsaknad av tillit för vuxenvärlden, oavsett om det handlar om föräldrar eller skolpersonal, är att barn och ungdomar söker sig till gatan, kompisgäng och subkulturer. Det bör samtidigt understrykas att när de intervjuade talar om 
ogynnsamma hemförhållanden relateras frågan ständigt till föräldrarnas invandrarbakgrund (för liknande diskussion se Brune 2004; Ericsson et al. 2002).

En av de intervjuade som arbetar med psykosociala frågor framhåller att migrationserfarenheter påverkar negativt föräldrarnas psykosociala välmående och således förmågan att ta hand om barnen samt att "föräldrarna inte vet alla gånger hur man uppmuntrar barnen". Problemet handlar inte bara om föräldrarnas psykiska välmående och att det råder brist på kunskap och engagemang bland föräldrarna, utan även om att de har kunskaper och förhållningssätt som är felaktiga, olämpliga eller rent av inkommensurabla med 'svenska normer'. Det som återkommande beskrivs som ett problem är att vissa föräldrar bär på erfarenheter av att leva i politiska system, familjestrukturer och kulturer som är vitt skilda från 'det svenska', vilket i sig sägs ha en rad svåra konsekvenser för fostran i allmänhet och gränssättande gentemot barnen i synnerhet (jfr Gruber 2007; Dahlstedt och Hertzberg 2011). Socionomen Lars menar exempelvis att "föräldrarna kommer från länder där skolsystemet är helt annorlunda", vilket gör att de har en helt annan syn på fostran och helt andra förväntningar på skolan. På liknande sätt påpekar en polisman att vissa "invandrarföräldrar", har ett "helt annat tänk på straff än man har i det så kallade väst" och att dessa föräldrar anser att det i samhället finns en "flathet", att "man bara daltar med folk".

Ytterligare en dimension tycks vara invandrarföräldrarnas bristande anpassning till majoritetssamhällets normer och förhållningssätt samt deras sociokulturella isolering - faktorer som enligt de intervjuade kan leda till omvända generationsbaserade hierarkier där barnen får mer makt än sina föräldrar eftersom de lättare kan orientera sig i det omgivande majoritetssamhället. Problemen medför att framförallt söner anses kunna ta över kontrollen i och över familjen och "börjar styra och ställa". Paradoxalt nog, samtidigt som vi får ta del av bilder av bristande gränssättning och omvända maktförhållanden i familjen, så framträder även bilder av auktoritära familjestrukturer och vuxnas förhållningssätt gentemot barnen. Genusroller har i detta sammanhang en särskild viktig referensram.

Områdens föräldrars fostran och syn på barn ställs mot andra så kallade svenska och normerande sätt att behandla flickor/kvinnor respektive pojkar/män (jfr Eliassi 2014). När en av polismännen berättar om arbetet med så kallade stökiga ungdomar konstaterar han att tjejer sällan utgör något egentligt problem, eftersom de enligt honom "oftast är hårt hållna". Killarna, däremot, "släpps vilt". Det är emellertid inte bara föräldrarna som utövar kontroll i familjen, utan även barnen själv, främst sönerna fostras till att utöva kontroll/övervakar sina systrar, menar flera av de intervjuade. Problematiseringarna känns igen från och är i linje med Runstens (2006) slutsatser att tjejers kontroll innefattar både generations- och genusaspekter, och att fäder, bröder och manliga släktingar spelar en avgörande roll i upprätthållandet av normer och maktrelationer. Pojkar från Sandberg beskrivs också som offer, men deras offerposition tycks vara mer subtil, särskilt när killarnas livsval uppfattas som avvikande från maskulinitetsideal, religiösa och kulturella normer och föräldrarnas sociala bakgrund och förväntningar. 


\section{AKTIVERING, EGENMAKT OCH DISCIPLINERING AV FÖRÄLDRAR}

Även om beskrivningarna av orsaksfaktorer är sammanflätade, går det att urskilja tre centrala orsaksförklaringar: segregerad närmiljö (till exempel kriminalitet, undermåliga skolor och boendemiljöer samt hög arbetslöshet), hemförhållanden (till exempel föräldrars bristande engagemang, våld i hemmet och föräldrars psykosociala problem) och invandrarskap (till exempel isolering och synen på fostran).

Lösningarna handlar ofta om insatser som syftar till att förbättra den urbana närmiljön (till exempel genom att få bukt med oseriöst bostadsägande och göra Området mer attraktivt för andra grupper), öka sysselsättningsgraden (till exempel genom arbetsmarknadsinsatser), göra ordningsmakten mer synlig på gatan och i skolan (till exempel genom fler närpoliser och områdesvärdar), förbättra skolresultat (genom organisatoriska förändringar) samt kommunicera en mer positiv bild av området (Dahlstedt och Lozic 2018). Dessutom har fritidsaktiviteter och ungdomspraktikplatser klassificerats som betydelsefulla åtgärder, vilka syftar till att få till stånd beteendemönster, livsstilar, yrkesroller och sociala nätverk som är mer i linje med samhällsnormer för eftersträvansvärt ungdomsbeteende. Låt mig dock fokusera på de lösningar som har en särställning i intervjumaterialet och fältobservationerna, och som kan kategoriseras som fostran, kommunikation och prevention. Alla dessa lösningar är sammanflätade med varandra och dessutom oskiljaktiga från problematiseringar av urban närmiljö, hemförhållande och invandrarskap, vilka är tre centrala orsaksförklaringar.

\section{Fostran}

De intervjuade framhåller att när invandrarföräldrars kultur, normer, beteendemönster och kunskaper avviker från majoritetssamhällets, ökar också risken för att ungdomar utvecklar ett, ur organisationsrepresentanternas perspektiv, problematiskt beteende. Härigenom konstrueras invandrarskap och således invandrare som "motpoler till eller problem för den normala ordningen, men också som objekt för ordningsskapande" lösningar (Brune 2004, 357). Fostran till normerande föräldraskap och medborgarskap har en central plats i lösningar som efterfrågas. Föräldrakurser, festligheter, föräldramöten och informationsträffar med representanter från arbetsförmedlingen, konsumentorganisationer, bostadsägare, föreningar, företag, ekonomisk rådgivning eller polisen är flera exempel på initierade lösningar som syftar till att omvandla eller omskola föräldrar och andra familjemedlemmar, så att deras handlande följer medborgarideal och således bidrar till ordningsskapande (Fältobservationer 2015, 2016 och 2017).

Enligt polisen Ingvar är det exempelvis viktigt att förklara för föräldrarna "vad barnuppfostran är" så att de förstår att "om man är här i Sverige så uppfostrar man på ett sätt, [och om man är] i Afrikaländerna så lär man sig på ett annat sätt". På liknande 
sätt argumenterar rektorn Carina för behovet av att normalisera och aktivera föräldrarna så att de kommer på föräldramöten och lär sig "värdegrund, värderingar och lagstiftning" som har direkt relevans för barns uppfostran och utbildning. Argumentet att "man behöver jobba med föräldrarna, [och] lära dem hur man ska handskas med barnen", såsom kommunrepresentant Nicklas uttrycker det, är ytterligare ett exempel på lösningar som ska verka på djupet i syfte att utveckla individens egenmakt och i förlängningen påverka föräldrars handlande, värderingar och förståelsehorisont och anpassa dem till föreställda normer. Det bör samtidigt påpekas att även om man sällan benämner normerna som svenska så finns detta underförstått i kontexten.

Men problematiseringarna handlar inte bara om att förändra föräldrarnas sätt att fostra barnen, utan även om att över huvud taget "hitta föräldrarnas engagemang $i$ barnen", det vill säga aktivera föräldrarna så att "de också är delaktiga" i barnens liv. Att "stärka människor" handlar enligt några av de intervjuade om att "bygga upp beredskap hos föräldrarna" och "få in föräldrarnas engagemang" (fritidssamordnare Raul, ungdomshjälpsrepresentant Thalia). Dessa aktiveringsinsatser och kunskapslyft måste relateras till problembilder i vilka föräldrarna skildras som passiva, okunniga, oansvariga och implicit som osvenska (Dahlstedt 2015).

För det första innefattar synen på fostran idéer om förändring av individernas normer och kunskapsbas (till exempel aktivering, att lära dem svensk värdegrund och svenska lagar) samt ökad egenmakt, så att individen på egen hand ska kunna ta ansvar för sig själv, sina barn och området, samt delta i samhället och påverka dess utveckling (jfr. Lozic 2016). Strävan efter att å ena sidan stärka föräldrarna och å andra sidan fostra, normalisera och göra dem mer förändringsbenägna, är inte en motsättning i sig utan dessa processer kompletterar varandra och är integrerade delar av efterfrågade lösningar.

För det andra är omvandlingsprocesser exempel på medborgarskapandet (Dahlstedt 2009). Att inte komma på och aktivt delta i föräldramöten, att vara passiv eller oengagerad i för Sandberg relevanta frågor samt att låta barnen vara obevakade och okontrollerade, alternativt att vara alltför kontrollerande när det gäller barnuppfostran, finns inte som möjliga val, i alla fall inte om de intervjuade får som de vill. Och om man upptäcker avvikande beteenden iscensätts olika fostringsmetoder som syftar till att producera normerande medborgare som förväntas ta sitt moraliska ansvar (Rose 1999).

För det tredje är det rimligt att tolka fostran som exempel på både empowerment (egenmakt) och normalisering. Exempelvis anser man att medborgarna behöver de rätta verktygen för att engagera sig i förändringen av sina och områdets villkor. Denna verklighetsbeskrivning leder till att organisationsrepresentanterna iscensätter kunskapslyft, som möjliggör omvandling av individernas kunskaper och normsystem samt deras aktivering. Samtidigt är empowerment en form av maktutövning "som vill göra det möjligt för individen att styra sig själv genom upplysta och rationella val" och som gör att individen aktiverar sig själv (Johansson 2012, 128). Exempelvis är kraven på utbildning i hur man fostrar barnen eller kraven på att föräldrarna aktiveras exempel på lösningar där disciplinering och empowerment flätas samman. Poängen är 
att disciplinering och empowerment är två sidor av samma mynt - de är integrerade delar av styrningsprocessen som här beskrivs.

\section{Kommunikation}

För att lösningar överhuvudtaget ska kunna ske och vara framgångsrika behövs kommunikativa kontaktytor där organisationsrepresentanter och boende möts och utbyter erfarenheter, manar man. De intervjuade och deltagarna inom den samverkansprocess som jag observerat menar samtidigt att det är svårt att skapa sådana kontaktytor. Huvudkritiken är att befolkningen visar lågt engagemang; det finns stora skillnader mellan organisationsrepresentanternas och de boendes tankesätt; föräldrarna är "svåra", osynliga och passiva samt att ett fåtal organisations- och myndighetsrepresentanter är bosatta i området och erkända av den lokala befolkningen (jfr Frick 2005). Det finns även de som menar att många personer är trötta på att vara objekt för projekt, vilket ytterligare försvårar kommunikationen. Det finns fog för antagandet att organisationerna hittills har haft begränsade framgångar med att uppnå sina mål, såsom utveckling av egenmakt (empowerment), disciplinering och normalisering.

Som svar på dessa utmaningar har det utvecklats ett tankemönster utifrån idén att utvidgade och fördjupade kontaktytor mellan organisationer och medborgare kan vara en grund för ömsesidigt beroende, ömsesidig tillit och förståelse samt ökad medborgerlig delaktighet. Syftet är även att bättre uppnå organisationens egna mål. Arbetsmetoderna man använder sig av är mångfaldiga, men handlar huvudsakligen om organisering av kulturevenemang och festligheter, studiecirklar och kurser, dörr till dörr-informationskampanjer och mötesplattformer (till exempel medborgarkontoren), där de boende kan få kostnadsfri rådgivning kring arbetsmarknad, trygghet och säkerhet, boendetrivsel, utbildning, föräldraskap, konsumentskydd och så vidare. Värt att notera är att samverkansprocess i dessa sammanhang har blivit ett ledord.

Grundtanken med dessa samverkansprocesser är att skapa kontaktytor organisationer emellan och mellan medborgare och organisationer och medborgare emellan. Målet är nya idéer, effektivisering, bättre genomslagskraft och helhetsperspektiv på området, medborgare och andra problembilder (jfr Dahlstedt och Lozic 2018). Idén om samverkan kan exempelvis handla om att skolorna samverkar med polisen, socialen, frivilligorganisationer samt andra myndigheter och organisationer, i syfte att förbättra skolresultat, minska konflikter, öka trygghet i området, få till stånd föräldrarnas engagemang, ordna praktikplatser och jobb åt ungdomarna, använda skolan som en informationsplattform och så vidare.

Slutsatsen som kan dras är att flera samverkansprocesser varigenom man försöker inkludera och involvera föräldrar syftar till att målgruppen ska få ökade kunskaper och påverka agendan samt delta i meningsutbyte med myndighetsrepresentanter. Organisationerna önskar å sin sida anpassa sitt sätt att arbete till målgruppen och förhållanden som råder i området. 


\section{Prevention}

En återkommande ståndpunkt i diskussionen om lösningar är att ett effektivt och framgångsrikt åtgärdsarbete kräver inte bara kommunikativa kontaktytor och fostran, utan även tidiga insatser och prevention. Genom tidig kartläggning hoppas man kunna upptäcka och särskilja avvikande beteende och prognosticera framtida problem. Kommunrepresentant Nicklas poängterar till exempel att tidiga åtgärdsinsatser kan ha en preventiv och korrigerande funktion, för ju tidigare man ingriper desto lättare är det att nå ett eftersträvansvärt resultat.

När man är liten då har man små problem och om man väntar tills [barnen] blir stora [då får man större problem]. Man kan tidigt se att vissa barn har [...] en slags personlighet. Det känns hemskt att säga så om små barn, men med de barnen behöver man vara mer vaksam. Man måste fånga upp dem mycket, mycket tidigare och jobba mer med föräldrarna.

Grundidén bakom tidiga insatser, prevention och prognostisering är att så snabbt som möjligt rätta till barns och föräldrars brister och medvetandegöra dem om de fel de har begått eller är på väg att begå.

För att tidigt kunna upptäcka potentiella problem söker man efter "kontaktytor" där man kan upptäcka individer som befaras kunna bli ett problem. Mödravården kan enligt polisen Jesper tjäna som en central arena för detta ändamål, eftersom mödravården är en plats där samhället tidigt kan diagnosticera eventuella avvikelser och initiera åtgärdsinsatser.

Man kan tidigt se [potentiella problem]. Redan under mödravårdstiden, när man är på gång att skaffa barn, då skulle man tidigt, och speciellt i områden där behoven finns [sic], [agera]. Man ska vara ännu starkare och finnas med. Om du ska påverka en persons liv, en människas liv så tycker jag att man ska göra detta från början, redan vid spädbarnsålder. I spädbarnsåldern så har du möjlighet att med ganska små och enkla medel prägla ett barn och få en rätt så stor genomslagskraft.

Mödra- och barnavård tycks, på grund av institutionernas ofrånkomlighet i föräldraskapet, vara särskilt lämpliga arenor för övervakning, analys, kategorisering, prevention och prognostisering samt där man kan "stärka föräldrarna" och "ge dem verktyg" så att de kan "förändra någonting". Det finns således ett nära samband mellan kunskapen om föräldrarna och koordineringen av insatser vars syfte är att skapa bestämda former av föräldraskap och barnsubjekt.

Men skolan tycks vara en ännu viktigare arena för styrning, menar polisen Jesper.

Skolan är en bas till att fånga upp [barnen och föräldrarna]. Egentligen är det först när du kommer till skolan, det är där du blir sedd och hörd som individ och det är där samhället för första gången kan riktigt göra en kartläggning av individen och familjen och hur man har det. Det är i skolan som man för första gången har en möjlighet att göra någon granskning.

Likaså hävdas det att eftersom skolan är obligatorisk och alla passerar genom den, är den en ypperlig arena för att hindra utveckling av problematiskt beteende (jfr 
Johansson 2012; Dahlstedt och Hertzberg 2011). Polisen Andreas klargör att lärare redan på lågstadiet kan se "'Skit, det här kommer att bli ett problem!'” och därför efterfrågar han "jättestora resurser", "stöttning" och "uppbackning" i skolan.

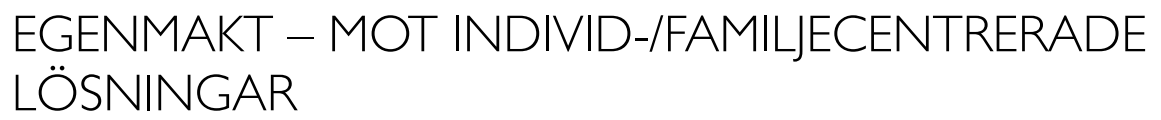

Den kanske mest iögonfallande slutsatsen av analysen av organisationsrepresentanternas (från exempelvis polis, socialtjänst, skola och frivilligorganisationer) beskrivningar av orsaker till att vissa ungdomar utvecklar ett, enligt organisationsrepresentanterna, problematiskt beteende är att de aviserade lösningarna går att finna i skärningspunkten mellan problematiska hemförhållanden, vars existens relateras till den invandrartäta urbana närmiljön, och invandrarskap. Poängen är att de mest framträdande och konkreta lösningarna på ungdomsproblem är individcentrerade eller rättare sagt familjecentrerade. Med andra ord, även om de intervjuade identifierar dominerande strukturella problem och lösningar, kretsar majoriteten av föreskrivna lösningar kring styrning av familjen. Ungdomsproblem ska således lösas genom att fokusera på familjen. Slutsatsen känns igen från Alwalls och Stigendals (i denna antologi) påpekande att problemens lösningar söks "utifrån ett uppfattat behov av att förändra just dessa ungdomar och deras närmaste omgivning". Målet tycks vara fostran av familjen i fråga om kunskaper och normer, samt att göra föräldrarna mer delaktiga i och aktiva och ansvarstagande när det gäller barnen och det som sker i den lokala närmiljön - precis som det tycks vara fallet med förväntansdokumentet/ansvarskontraktet. Detta trots att en av boendevärdarna poängterar på ett samverkansmöte att det enda långsiktiga och riktigt hållbara lösningen på övergripande problem i området är att hitta förvärvsarbete till de boende i området och på så sätt förändra deras livsvillkor. Hans kommentar kan relateras till synen att medborgarskap och det goda livet i första hand handlar om individens inkludering i lönearbete (för vidare diskussion se Alwall och Stigendal i denna antologi). Men för vår del kanske mest intressanta är boendevärdens problematiseringar av de lösningar som dominerar i Sandberg, eftersom de enligt honom inte angriper huvudproblemet, nämligen arbetslösheten och socioekonomiska problem (med andra ord problem på strukturell nivå).

Därmed går det att tala om en missmatch mellan orsaksförklaringar till ungdomsproblemen, som har en artikulerad strukturell, social och individuell dimension, och lösningar, som har en mer uttalad individ- och familjecentrerad karaktär. En trolig anledning för denna diskrepans är att strukturer är trögrörliga och svåra att förändra, medan insatser på individ- och familjenivå är inom räckhåll för de individer vars reflektioner analyseras i detta kapitel (jfr. Alwall och Stigendal i denna antologi). Men Bacchi $(2010,2)$ poängterar att "what we propose to do about something reveals what we think needs to change and hence what we think the 'problem' is". 
Detta leder mig till kapitlets huvudpoäng, nämligen slutsatsen att diskrepansen mellan strukturella, sociala och individuella orsaksförklaringar å ena sidan och aviserade individ- och familjecentrerade lösningar å andra sidan, beror på en ökad fokusering på individens roll, ansvar och skyldighet. Det är i detta sammanhang viktigt att poängtera att när man flyttar sökarljuset från den strukturella nivån till individen/familjen/ungdomen som bärare av problem, skiftar man också lösningar till den privata sfären och individens kultur, kunskaper, livsval och erfarenheter. Att vi i dagens Malmö kan se ett krav på ett "ansvarskontrakt" mellan skolan och föräldrar är därmed inte överraskande, inte minst med tanke på de senaste decenniernas ökade fokus på medborgarnas ansvar och plikt snarare än deras rättigheter (för vidareläsning om ett historiskt förändringsperspektiv och så kallat 'regimskifte' mot aktiveringens politik se exempelvis Dahlstedt 2009, 2015). Att undersöka hur problematiserade barn, ungdomar och föräldrar ser på rådande problematiseringar är en fråga för vidare forskning.

\section{REFERENSER}

Bacchi, Carol (2010) Foucault, policy and rule: Challenging the problem-solving paradigm. Aalborg: Aalborg Universitet.

Brune, Ylva (2004) Nyheter från gränsen: Tre studier i journalistik om "invandrare", flyktingar och rasistiskt våld. Göteborg: Göteborgs universitet.

Bunar, Nihad (2010) "Choosing for quality or inequality: Current perspectives on the implementation of school choice policy in Sweden", Journal of education policy 25(1):1-18.

Böhlmark, Anders, Helena Holmlund och Mikael Lindahl (2015) Skolsegregation och skolval. Uppsala: IFAU

Dahlstedt, Magnus (2009) Aktiveringens politik: Demokrati och medborgarskap för ett nytt millenium. Malmö: Liber.

Dahlstedt, Magnus (2015) "The politics of making demands: Discourses of urban exclusion and medialized politics in Sweden", International journal of politics, culture, and society 28(2):101-117.

Dahlstedt, Magnus och Fredrik Hertzberg (2011) Skola i samverkan: Miljonprogrammet och visionen om den öppna skolan. Malmö: Gleerup.

Dahlstedt, Magnus och Vanja Lozic (2018) "Lokalsamhället, gemenskapen och viljan att samverka" i Magnus Dahlstedt (red.) Förortsdrömmar: Ungdom, utanförskap och viljan till inkludering. Linköpings universitet: Norrköping, 71-87.

Eliassi, Barzoo (2014) "Constructing cultural otherness in the Swedish welfare state", Qualitative Social Work 14(4): 554-571. 
Ericsson, Urban, Irene Molina och Per-Markku Ristilammi (2002) Miljonprogram och media: Föreställningar om människors och förorter. Stockholm, Norrköping: Riksantikvarieämbetet, Integrationsverket.

Frick, Peter (2005) "The making of place", i Mette Andersson, Yngve G. Lithman och Ove Sernhede (red.) Youth, otherness and the plural city: Modes of belonging and social life. Göteborg: Daidalos, 139-159.

Gruber, Sabine (2007) Skolan gör skillnad: etnicitet och institutionell praktik. Norrköping: Linköpings universitet.

Hattie, John (2009) Visible learning : a synthesis of over 800 meta-analyses relating to achievement. London: Routledge.

Håkansson, Jan och Daniel Sundberg (2012) Utmärkt undervisning : framgångsfaktorer i svensk och internationell belysning. Stockholm: Natur \& Kultur.

Isling Poromaa, Pär (2016) Den subtila ojämlikheten : om grundskolors materiella förutsättningar och elevers utbildningsmöjligheter. Umeå: Umeå universitet.

Johansson, Kerstin (2012) "Mellan stöd och kontroll: Prevention riktad mot föräldrar, barn och unga", 127-150 i Kenneth Petersson, Miagnus Dahlstedt och Birgitta Plymoth (red.) Fostran av framtidens medborgare: Normer och praktiker bortom välfärdsstaten. Lund: Sekel, 127-150.

Kallstenius, Jenny (2010) De mångkulturella innerstadsskolorna : om skolval, segregation och utbildningsstrategier i Stockholm. Stockholm: Acta Universitatis Stockholmiensis.

Kamali, Masoud (2006) Den segregerande integrationen: Om social sammanhållning och dess hinder: SOU 2006:73. Stockholm: Fritze.

Kings, Lisa (2011) Till det lokalas försvar: Civilsamhället i den urbana periferin. Lund: Arkiv.

Korpi, Walter och Joakim Palme (2003) "New politics and glass politics in the context of austerity and globalization: Welfare state regress in 18 countries, 1975-95", The American political science review 97(3):425-446.

Liberalerna (2019) Förväntansdokument (ansvarskontrakt) på Malmös skolor till hösten. Hämtad 2019-08-19 från https://malmo.liberalerna.se/blog/ forvantansdokument-ansvarskontrakt-pa-malmos-skolor-till-hosten/

Lozic, Vanja (2016) 'Normalisering av ungdomar i problem genom styrning av föräldrar: från strukturella orsaksförklaringar till familjecentrerade lösningar' i: Sociologisk forskning, 53(2):151-174.

Lozic, Vanja (2018) "Att lära av det lokala och experimentera : Resilienstänkande i brottsförebyggande arbete" i Arkiv : Tidskrift för samhällsanalys, 9:129-157.

Nordström-Skans, Oskar och Olof Åslund (2010) Segregationen i storstäderna: Bostadsområden, arbetsplatser, skolor och familjebildning 1985-2006. Uppsala: IFAU.

Magnusson, Susanne (2014) Att säkerställa att vi är välkomna: Om organisationers strategiska kommunikation och förtroendeskapande arbete i det mångkulturella samhället. Lund: Lunds universitet. 
Ristilammi, Per-Markku (1999) Rosengård och den svarta poesin: En studie i modern annorlundahet. Stockholm, Stehag: Brutus Östlings bokförlag, Symposion.

Rodenstedt, Ann (2014) Living in the calm and safe part of the city: The socio-spatial reproduction of upper-middle class neighbourhoods in Malmö. Uppsala: Uppsala universitet

Rose, Nicklas (1999) Powers of freedom: Reframing political thought. Cambridge, UK; New York, US: Cambridge University Press.

Schierup, Carl-Ulrik, Aleksandra Ålund \& Lisa Kings (2014) "Reading the Stockholm riots: A moment for social justice?", Race \& class 55(3):1-21.

Sjögren, David (2010) Den säkra zonen. Umeå: Umeå universitet.

Skolverket (2009) Vad påverkar resultaten i svensk grundskola. Stockholm: Skolverket.

SR (2019) Föräldrar i Malmö måste vara positiva till skolan. Sveriges radio. https:// sverigesradio.se/sida/artikel.aspx?programid=83\&artikel=7226031 (Hämtad 2019-08-19)

Stigendal, Mikael (1999) Sociala värden i olika sociala världar: Segregation och integration $i$ storstaden. Lund: Studentlitteratur.

SVT (2019) Politikerna överens: Malmös föräldrar måste skriva kontrakt med skolan. Sveriges television. https://www.svt.se/nyheter/lokalt/skane/klart-foraldrar-i-malmo-maste-skriva-kontrakt-med-skolan. (Hämtad 2019-08-19)

Velásquez, Joan, A. (2005) Förankring och dialog: Kraftspelet mellan planering och demokrati. Stockholm: Stockholms universitet. 


\title{
Ungdomar - problem eller potential?
}

\author{
Jonas Alwall \& Mikael Stigendal
}

\section{INLEDNING}

Många ungdomar befinner sig på den nutida ojämlikhetens förlorarsida. Vi märker det på en rad olika sätt, såsom i statistik över t ex psykisk ohälsa, skuldsättning, boende, tillfälliga anställningar och ofullständiga betyg. Medierapporteringen och samhällsdebatten intresserar sig dock mest för de ungdomar som ingår i kriminella gäng, som köper och säljer droger, som kastar sten eller beter sig destruktivt på andra sätt. Vilka problemen är framstår som uppenbart.

Skildringar av problem i Malmö har under många år i hög grad utgjort ett narrativ med ungdomar i en destruktiv roll. Genom detta narrativ beskrivs ungdomar som antingen våldsförövare eller våldsoffer, men våldet förklaras sällan bortom dessa ungdomars eget aktörskap. Man ser våldshandlingar som något ungdomar utför eller utsätts för; man ser att det görs och vad det får för direkta konsekvenser. Men vad själva våldet beror på erbjuder detta narrativ inga förklaringar till.

I detta kapitel vill vi lyfta fram ett perspektiv vari ingår att se ungdomars destruktiva beteende som något som egentligen utgör symptom på en grundläggande ojämlikhet. Vi menar att det är nödvändigt att gå bakom de synliga, manifesta problem som ungdomar i det förhärskande narrativet ses som bärare av och i stället titta på de mer grundläggande problem i vår nutida samhällsstruktur som dessa ungdomars beteende har kommit att manifestera. När vi här talar om problem så menar vi alltså något som finns på båda nivåerna. Självklart utgör exemplen på ungdomars våldsanvändning problem för det lokala samhället, men de är problem som har orsaker och dessa orsaker utgör i sin tur mer grundläggande problem. Dessa "orsaksproblem" kan ha sitt ursprung på andra nivåer, på andra platser och i andra människors aktörskap än de "symptomproblem" vi ser.

Det förhållningssätt vi här vill framhålla är alltså ett som söker sig bakom det synliga och manifesta och vill identifiera bakomliggande orsaker. Vidare, när vi i rubriken till detta kapitel sätter begreppet problem i motsats till potential - och kopplar dessa båda begrepp till ungdomar - så ska det, på motsvarande sätt, inte tolkas som att vi ser ungdomar som bärare av antingen enbart problem eller potentialer. De kan 
självklart vara båda delarna, men inte heller det är vår poäng. Det vi vill belysa är två förhållningssätt som ofta inte framträder tydligt eller företräds uttalat, och som därför kan ge sken av att uttrycka eller förhålla sig till samma sak ("problem"), men som i grunden är kvalitativt olika. Vi kommer i det följande att tala om dessa båda förhållningssätt som det problemorienterade respektive det potentialorienterade. Förhållningssätt - snarare än bara perspektiv eller synsätt - utgör dessa eftersom de inte bara sitter i huvudet utan även i attityder och beteenden; de rymmer inställningar som är handlingsorienterade och som därför får praktiska konsekvenser.

\section{DETVÅ FÖRHÅLLNINGSSÄTTEN}

I detta avsnitt presenteras de ovan nämnda förhållningssätten - det problemorienterade och det potentialorienterade - mer i detalj, och de länkas till aktuella samhällsprocesser. Vi vill här särskilt lyfta fram vad vi ser som slagkraften hos det potentialorienterade förhållningssättet, som ett sätt att tänka kring ungdomars situation men också som vägledande i ett sökande efter lösningar på samhällsproblem. För att kunna göra det behöver vi dock också skärskåda det problemorienterade förhållningssättet, med dess förhärskande diskurs om inkludering, och vilka konsekvenser det kan få när det omsätts i praktisk handling, verksamheter och satsningar. Det är därför där vi börjar.

\section{Det problemorienterade förhållningssättet och inkluderingsagendan}

Det problemorienterade förhållningssättet har alltså en grundläggande betydelse för det narrativ om ungdomars situation som vi idag möter i olika sammanhang men också, menar vi, i konkreta satsningar och åtgärder för att komma tillrätta med "ungdomsproblem". En mångfald exempel på detta förhållningssätt fann vi i det europeiska forskningsprojekt, Citispyce, som vi båda var engagerade i mellan åren 2013 och 2015 och där vi samarbetade med forskare och praktiker från tio städer runtom i Europa (Stigendal, 2018). Syftet med Citispyce var att skapa kunskap om den ojämlikhet som ungdomar drabbas av och hur den kan bekämpas. Åtskilliga av exemplen på verksamheter och insatser från dessa städer - syftande till att inkludera ungdomar - vittnade om ett förhållningssätt där det oftast handlade om att bekämpa problemens symptom snarare än deras orsaker. Problemen kunde ofta identifieras som att ungdomar befann sig i en position av utanförskap i relation till det etablerade samhället - dess arbetsmarknad, bostadsmarknad etc - och åtgärderna handlade om att på olika sätt föra in ungdomarna i detta samhälle. Just häri ligger, menar vi, det problematiska med detta förhållningssätt: ungdomarna ska föras in i det befintliga samhället utan att de orsaker bekämpas som har marginaliserat och exkluderat dem. Detta förhållningssätt har ibland kommit att få bära namnet inkludering. 
Det problemorienterade förhållningssättet är inte bara märkbart i lokala diskussioner om problem i Malmö eller andra städer utan även på en nationell politisk nivå och ändå upp på europeisk nivå, i form av det som brukar refereras till som EU:s inkluderingsagenda. Här möter vi alltså just termen inkludering som representerande en tankefigur där ungdomar ska inordnas i de befintliga samhällsstrukturerna. Inkludering - eller active inclusion - har under mer än 10 år varit EU:s centrala begrepp i förhållningssättet till utanförskap och fattigdom. Principen om active inclusion ingår också i EU:s övergripande strategi Europa 2020.

Inkluderingsagendan ska förstås utifrån en förskjutning i förståelsen av vad inkludering (och därmed dess motsats, exkludering) innebär: från ett inneslutande i en samhällsgemenskap - ett "socialt medborgarskap", för att använda en term hämtad från den brittiske sociologen T.H. Marshall (1950) - till i första hand en inkludering i lönearbete, alltså i den existerande arbetsmarknaden. Förskjutningen och det den representerar är inte något obetydligt. Det handlar inte bara, som i Sverige, om betonandet av "arbetslinjen" (även om det också yttrar sig så). I själva verket kan förskjutningen beskrivas som att det "inte längre [handlar] om samhällsgemenskapens skyldighet att skydda och upprätthålla medborgarnas universella rättigheter, utan omvänt om de enskilda medborgarnas, företagens och det civila samhällets moraliska plikt att bevara och skydda den sociala ordningen" (Schierup, 2015: 133). I en rapport från Eurofound (2015), Social inclusion of young people, kan det stora problemet utläsas, och det är att all vikt läggs vid att inkludera ungdomar i det existerande samhället utan att bekämpa de orsaker som har exkluderat dem. Detta stämmer överens med den "neo-Durkheimian hegemony" (Levitas, 2005: 188) som kännetecknas av att ta den existerande ordningen för given. Ett sådant fokus på de exkluderade "presupposes that there is nothing inherently wrong with contemporary society as long as it is made more inclusive through government policies" (Fairclough, 2000: 65).

Termen inkludering har dock för många en positiv klang. Inkludering låter helt enkelt som något bra. Bekymret är dock att den positivt laddade termen inkludering alltså så ofta får sin betydelse genom att ingå i ett, med vår term, problemorienterat förhållningssätt som innebär att människor - inte minst ungdomar - ska inordnas i en befintlig ordning vilken i sig inte antas behöva förändras eller utmanas.

Projekten som dokumenterades i Citispyce var mer eller mindre präglade av inkluderingsagendan. Ett centralt kännetecken är fokuseringen på individer, "motivated to integrate into mainstream society but in need of support" som det står i en av rapporterna (citerad i Stigendal, 2018: 150). Vid sidan om dessa har vi dock de andra ungdomarna, de som inte är "motiverade att integreras i det etablerade samhället", liksom de som har fått hjälp att ta sig in på arbetsmarknaden bara för att upptäcka vad den gör med dem. För många inom den senare gruppen har erfarenheterna av arbetslivet kommit att handla om otrygghet, vanmakt, ekonomisk stress, förlust av kontroll över sin egen tid samt - i förlängningen - en förlust av både kreativitet och personlig identitet. Många ungdomar har erfarenheter av behovsanställningar och $\mathrm{s}$ $\mathrm{k}$ nollkontrakt, alltså anställningar som rymmer maximal flexibilitet för arbetsgivaren men för ungdomen innebär närmast maximal ofrihet, eftersom hen alltid måste 
stå till förfogande och vara tillgänglig för de arbetstimmar som eventuellt dyker upp (Strandlund, Bernhard-Oettel \& Låstad, 2018). Många av dessa ungdomar har själva, och mycket påtagligt, fått erfara att samhället orsakar ojämlikhet, men när deras inkludering i den befintliga arbetsmarknaden blir normen finns det inget utrymme för deras erfarenheter och den kritik av den bestående ordningen de rymmer.

Därtill har vi alla de ungdomar för vilka inkluderingsagendan inte ens lyckas med sitt mest grundläggande anspråk: att etablera dem på arbetsmarknaden. Ett centralt problem med inkluderingsagendan är nämligen att den bara kan omfatta en del av alla de ungdomar som står utanför, vilket i sin tur är en effekt av dess tendens att individualisera problemen. I stället för att se ojämlikheten som en angelägenhet för oss alla - en fråga om samhällets framtid - gör inkluderingsagendan den till en individuell angelägenhet. Ungdomsforskarna Andy Furlong och Fred Cartmel har beskrivit processen så här:

Individuals are forced to negotiate a set of risks which impinge on all aspects of their daily lives, yet the intensification of individualism means that crises are perceived as individual shortcomings rather than the outcome of processes which are largely outwith the control of individuals. “..." Blind to the existence of powerful chains of interdependency, young people frequently attempt to resolve collective problems through individual action and hold themselves responsible for their inevitable failure. (Furlong \& Cartmel, 2007: 144)

Vid sidan om individualiseringen av problemen utmärks inkluderingsagendan också av "lokalism", alltså en tendens att avgränsa satsningar till enskilda bostadsområden eller stadsdelar vars befolkning antas vara bärare av problemen (jfr Robotham, 2005: 17). Det handlar här alltså inte om att identifiera lokal initiativkraft eller lokal kunskap - vilket av flera skäl hade kunnat vara lovvärt - utan om att "lokalisera" de enskilda individer som ses som problembärare och göra det område där de befinner sig till horisont för både de identifierade problemen och vad som ses som möjliga lösningar.

\section{DET POTENTIALORIENTERADE FÖRHÅLLNINGSSÄTTET}

Alternativet till det problemorienterade förhållningssättet kan kallas potentialorienterat (se t ex Stigendal, 2016; Stigendal \& Novy, 2018). Som begrepp markerar det potentialorienterade förhållningssättet ett skifte i fokus från det som ser ut att vara - till exempel destruktiva ungdomar - till de generativa mekanismer eller potentialer som utgör bakomliggande orsaker (Danermark et al., 2018). Innan vi med en säkrare kunskap kan uttala oss om vad som händer måste vi ta reda på vad som skulle kunna hända. Det ligger i linje med Aristoteles distinktion mellan det potentiella och det aktuella samt den vetenskapsteoretiska inriktning som heter kritisk realism (Stigendal, 2016). 
Till skillnad från det problemorienterade förhållningssättet avgränsar sig det potentialorienterade inte till det som synes vara. Detta kräver en annan kunskapssyn än den empiristiska, där man inriktar sig på att identifiera och sätta namn på regelbundna samband mellan observerbara fenomen och i sin kunskapsutveckling förlitar sig på statistiska korrelationer, vilka "remain the socially sanctioned way to arrive at 'evidence-based' research to inform public policy" (Bhaskar, Danermark \& Price 2018: 76). Betydelsen av det som ser ut att vara kan alltså, menar vi utifrån ett potentialorienterat synsätt, inte tas för given. Det som synes vara bör istället betraktas som symptom. Det vi främst bör intressera oss för är de bakomliggande orsakerna.

En styrka hos det potentialorienterade förhållningssättet ligger också just i själva termen potential, vilken väcker en annan typ av associationer och en annan typ av kreativitet än att bara fokusera på problem. Även om "potential" i detta förhållningssätt syftar på både det negativa (orsaksproblemen, med den osäkerhet som alltid finns kring om och hur de kommer att förverkligas) och det positiva (den ännu oförverkligade handlingskraft som människor besitter, det handlingsutrymme att göra gott som de kan komma att ta $\mathrm{i}$ anspråk etc) så rymmer det potentialorienterade förhållningssättet alltid insikten om att en annan utveckling är möjlig. Bland alla problemorienterade projekt studerade i Citispyce fann vi faktiskt också exempel på ett mer potentialorienterat förhållningssätt (dock inte i en helt uttalad eller renodlad form). I Brightful, ett initiativ för ungdomar som utvecklats runt några skolor i Malmö, såg vi exempel på en verksamhet som gjorde det möjligt för ungdomar "to express their sense of meaning, understand their own potential and perceive themselves in a wider social context" (Alwall \& Hellberg Lannerheim, 2018).

I våra mångåriga samarbeten med praktiker har termen potential också visat sig ha ett stort värde och tilltala både dem som i sitt arbete vill åstadkomma grundläggande förändringar och dem som genom denna term finner ett utryck för en tro på människors, $t$ ex ungdomars, inneboende kraft. Att tala om ett potentialorienterat förhållningssätt har därför visat sig ha en underlättande och stärkande roll i samarbetet med praktiker.

Utifrån ett potentialorienterat förhållningssätt kan båda förhållningssätten - det problemorienterade såväl som det potentialorienterade - förstås som potentialer. När vi analyserar dem är det just som potentialer, vilka dock, för att få en verkan, måste aktualiseras. Som potentialer måste förhållningssätten komma till användning (tilllämpas), vilket sker i konkreta sammanhang av konkreta människor.

I den utsträckning det saknas kunskaper om förhållningssätten och skillnaderna dem emellan - och det saknas ofta, menar vi - kanske beståndsdelar från de två förhållningssätten blandas. Det kan skapa en försvårande osäkerhet. Men bara för att en viss satsning befinns bygga på ett problemorienterat förhållningssätt menar vi alltså inte att den kategoriskt kan avfärdas. Sådana satsningar måste inte leda till dåliga resultat, eftersom resultaten också beror på hur, var, när och av vem detta förhållningssätt aktualiseras. De problematiska utgångspunkterna kanske kan vändas till något positivt i det konkreta sammanhanget. Dessa utgångspunkter utgör dock begränsningar som kan stjälpa möjligheten till ett bra utfall, och även detta är en viktig insikt 
att ta med sig i en analys. I avslutningen av detta kapitel kommer vi att illustrera hur ett potentialorienterat förhållningssätt inte bara har en teoretisk fördel - alltså inte bara är bättre tänkt - utan också, under rätt omständigheter, har bättre förutsättningar att minska ojämlikheten.

\section{MALMÖKOMMISSIONEN}

Till satsningar i Malmö som onekligen har skapat en betydande potential men vars genomslag fortfarande, nio år efter att den inleddes, ter sig ovisst hör Malmökommissionen. En av de viktigaste utgångspunkterna för Malmökommissionen var den WHO-kommission som leddes av Michael Marmot och resulterade i rapporten Closing the gap in a generation (WHO, 2008). I detta och även andra arbeten har Marmot propagerat för en fokusering på "causes of the causes" och med det menat "the fundamental global and national structures of social hierarchy and the socially determined conditions these create in which people grow, live, work, and age". (WHO, 2008: 42) Dessa tankar låg också till grund för Malmökommisionens slutrapport (Stigendal \& Östergren, 2013: 78).

Vi vill här med "causes of the causes" mena det samma som potentiella orsaker, dvs de orsaker som, för att få en effekt, måste aktualiseras i ett visst konkret sammanhang då de modifieras till aktuella orsaker. En sådan tolkning är överensstämmande med ett potentialorienterat perspektiv. Det är även annat i Malmökommissionens slutrapport och tydligast blir det nog i idén om kunskapsallianser, alltså, som det formuleras i slutrapporten,

jämlika samarbeten mellan forskare och intressenter från till exempel förvaltning, föreningsliv och näringsliv, inriktade på att förena excellens och relevans. /.../ Ambitionen är att alla parters intressen ska tillgodoses. Det ska gälla en innovativ samhällsutveckling lika mycket som forskning och även utbildning. Deltagandet ska innebära ett ömsesidigt lärande och utveckling av ny kunskap. (ibid.: 121)

Enligt den kunskapssyn som idén om kunskapsallianser bygger på betraktas kunskap inte bara som något på förhand skapat utan skapandet och utvecklande av kunskap görs dessutom till del av lösningarna. Delaktigheten i en kunskapsallians ska grunda sig på ens erfarenheter och kunskaper, oavsett kombinationen av fakta-, förståelse-, färdighets- och förståelsekunskap, d.v.s. de fyra 'f' - kunskapsformer - som identifieras av bl.a. Läroplan för grundskolan 2011 och som vi menar utgör ett utmärkt sätt att fånga kunskapsbegreppets olika aspekter. Det potentialorienterade förhållningssättet har ett stöd i Malmökommissionens slutrapport men den teoretiska förståelsen av det har därefter utvecklats vidare (Stigendal, 2016; 2018; Stigendal \& Novy, 2018). 


\section{PÅGÅENDE PROCESSER I MALMÖ}

Det problemorienterade förhållningssättet uppfattas ofta ha en tydlighet som kan få satsningar och verksamheter präglade av det att framstå som lockande. Det angriper problem som människor kan känna igen - uppenbara (manifesta) problem, ovan även kallade symptomproblem - och de sätt på vilka det griper sig an problemen kräver inte av människor att de omprövar sin förståelse av hur samhället fungerar eller vad som utgör dess utmaningar. Mångåriga forskningserfarenheter, inte minst från Malmö, säger oss att det problemorienterade förhållningssättet är seglivat och har en benägenhet att återkomma och framträda i form av olika initiativ och satsningar. Man kan därför fråga sig var Malmö står idag, sex år efter det att Malmökommissionens slutrapport presenterades.

Efter Malmökommission - och delvis i dess "skugga", d v s med ofta återkommande referenser till kommissionen och med den som inspiration och i viss mån kunskapsbas - genomförs i dagens Malmö ett antal satsningar (ordet "satsningar" syftar här inte på etablerade verksamheter utan på ett antal brett syftande och ofta anspråksfullt beskrivna processer, projekt eller samarbeten). I flera fall är dessa i ett tidigt skede eller har åtminstone ännu inte hunnit ge särskilt stora avtryck i den malmöitiska verkligheten. Ett antal sådana satsningar känner vi till och kan namnge, t ex:

- CTC (Communities that Care, beskrivet som "ett styrsystem för ett långsiktigt och systematiskt socialt preventionsarbete" (Malmö stad, 2019), vilket sedan 2018 genomförs med Malmö stad som huvudman),

- M21 (Malmö för det 21a århundradet, ett partnerskap mellan Malmö stad och i första hand näringslivet men också med akademi och idéburen sektor med syfte att "ta tillvara Malmös styrka och utveckla urbana innovationer, för att kunna möta framtidens samhälle och dess utmaningar" (Malmö stad, 2018)),

- Malmöandan (en överenskommelse mellan Malmö stad och idéburen sektor i Malmö syftande till "att förenkla och förbättra samverkan för att stärka Malmöbornas förutsättningar till välbefinnande, hälsa och ett meningsfullt liv" (Malmöandan, 2018))och

- Forward Malmö (som beskriver sig som "en rörelse med kommun, föreningar, näringslivet, akademin, civilsamhället och flera" (Forward Malmö, 2019) med syfte att förändra Malmö i en mer hållbar riktning).

Kan vi säga något om dessa satsningar i relation till de två förhållningssätt vi har identifierat? En svårighet är att förhållningssätten inte framträder uttalat. Det finns en vaghet i programförklaringar och formuleringar och det finns dessutom ofta ett glapp mellan retorik och praktisk verklighet. Ett litet exempel på det senare kan nämnas: I Malmöandans programförklaring talas det om att skapa en "mer jämlik, öppen och demokratisk stad", vilket kan uppfattas vara helt i linje med Malmökommissionen och ett potentialorienterat förhållningssätt, men när denna ambition bryts ner och till exempel kopplas till ungdomars villkor och problem så är det, på traditionellt 
problemorienterat sätt, livsstilsfaktorer som fokuseras (fysisk rörelse och aktivitet). Förändringsobjektet - alltså det som ska förändras - är i detta fall ungdomars tendens till stillasittande. Med respekt för den fysiska aktivitetens betydelse för hälsan kan vi konstatera att detta inte tar sig an några bakomliggande problem. Problemet som identifieras är ungdomars märkbara inaktivitet. Lösningen är att aktivera ungdomarna. En fråga om "varför?" behöver, utifrån detta instrumentella perspektiv, egentligen inte ställas.

Bland de nämnda exemplen på satsningar utgör CTC det tydligaste i fråga om förhållningssätt. Tydligast är det eftersom dess premisser är mest utförligt beskrivna. Satsningen beskrivs som en "samverkansprocess" med medverkan av "bland annat kommunala tjänstepersoner inom skola och socialtjänst, polis, civilsamhälle, boende och näringsliv" (Malmö stad, 2019). Satsningen har betydande anspråk; inom en femårsperiod siktar den mot att "användas som arbetssätt i hela staden" och den bygger områdesteam bestående av företrädare för de olika samhällssektorerna, under ledning av tjänstepersoner från Malmö stad. På Malmö stads hemsida sägs CTC gå "i linje med Malmökommissionens rekommendationer för en socialt hållbar stad" (ibid.). En närmare granskning av materialet från CTC-satsningen i Malmö får oss dock att dra slutsatsen att denna satsning inte representerar ett potentialorienterat förhållningssätt utan ett problemorienterat. Dess förändringsobjekt utgörs av "problembeteenden", värderingar och normer. Det större samhället och dess klassformationer - ja till och med kulturella mönster i en djupare mening - saknas i analysen. Den kunskapssyn som CTC företräder uppfattar vi som uttalat empiristisk i sin inriktning på regelbundna samband mellan observerbara fenomen (enligt satsningens eget material: "bakomliggande faktorer som kartlagts i detalj och som har bevisad koppling till problembeteenden") (Malmö stad, 2017). Trots att det även inom CTC talas om orsaker - och även om satsningen beskrivs som en preventiv verksamhet (alltså som en verksamhet syftande till att förebygga problem), vilket skulle kunna antyda att CTC har sitt fokus på problemens orsaker - menar vi att dess perspektiv på orsaker ter sig både snävt och instrumentellt. CTC menar med orsaker observerbara och utpekbara fenomen som har identifierats genom statistiska korrelationer. Orsakerna reduceras till "riskfaktorer" (jfr. Roumeliotis, 2016: 42), vilket är något helt annat än de potentiella orsaker som ingår i samhällssystemen, vilka aktualiseras i ett konkret sammanhang och där modifieras till aktuella orsaker. De lösningar som föreslås av CTC väcker inte ens frågan om förekomsten av sådana samhälleliga orsaker.

CTC:s trumfkort är att programmet är "evidensbaserat", alltså att det i ett flertal vetenskapliga prövningar sägs ha visat sig vara effektivt för att motverka de identifierade problemen. Statusen som evidensbaserad metod blir dock, menar vi, en självklar styrka enbart om vi anammar en empiristisk kunskapssyn och en instrumentell syn på relationen problem och lösningar och därtill ger vetenskaplig kunskap företräde framför alla andra kunskapsformer: alltså, lite förenklat, om vi accepterar en problemorienterad utgångspunkt. Sociologen Filip Roumeliotis (2016: 41-42) uttrycker följande kritiska kommentarer om ett sådant synsätt, just med referens till CTC-programmet: 
[The] aim of the program is to translate scientific knowledge into community practice, thus asserting the primacy of scientific knowledge over other modes of knowledge. Through various disciplinary techniques, the community is made into an object of knowledge. It is objectified, classified, and measured against a scientific norm of rationality. Through such techniques, the program is able to discern between legitimate and illegitimate political communities. It is only by becoming a community of experts, which includes the appropriation of the language of prevention science, that the community qualifies as a political subject.

Förutom i synen på vad som utgör problem och dessas orsaker kommer den empiristiska kunskapssyn som präglar CTC alltså också till uttryck i hur resultaten av insatserna bedöms. Ytterligare en kritisk punkt kan noteras när vi betraktar CTC, nämligen dess tendens att gå i den "lokalistiska" fälla som diskuterades ovan. Problemen finns, enligt ett sådant synsätt, där de unga "problembärarna" befinner sig - i dem själva och deras närmaste omgivning - och problemens lösningar söks därför utifrån ett uppfattat behov av att förändra just dessa ungdomar och denna närmaste omgivning.

\section{GNISTAN - GÖR NÅTI STAN}

Som har påpekats tidigare behöver de två förhållningssätt vi diskuterar - det problemorienterade och det potentialorienterade - inte alltid framträda som särskilt uttalade eller genomtänkta, och de behöver heller inte alltid vara formulerade i ord. De existerar ofta inte fullt ut i den form av kunskap som vi ovan har refererat till som förståelsekunskap. Ändå kan de genomsyra en verksamhet, då på mer intuitiva grunder och betingad av den form av kunskap som kallas förtrogenhetskunskap.

En verksamhet som vi menar i stor utsträckning genomsyras av ett potentialorienterat förhållningssätt är den som heter Gnistan (en förkortning av "Gör nåt i stan"). Vi ska därför använda oss av Gnistan för att visa vad skillnaderna mellan de två förhållningssätten kan innebära och hur ett potentialorienterat förhållningssätt kan komma till uttryck. Avslutningsvis vill vi dra slutsatser om vad en mer genomtänkt användning och en mer uttalad förståelse av ett potentialorienterat förhållningssätt skulle kunna innebära för Gnistan.

\section{Historik: Från ideellt via förening till kommun och tillbaka till förening}

Gnistan är en verksamhet för barn som ligger i området Augustenborg i Malmö, nere i en stor källarlokal i ett hus som ägs av det kommunala fastighetsbolaget MKB. Sedan den 1 november 2017 drivs Gnistan av en ideell förening. Barn och ungdomar i 
åldrarna 6-14 år erbjuds en fritidsverksamhet samtidigt som föräldrarna därmed får möjligheter att söka arbete, praktisera eller studera. Gnistan har en utomhuspedagogisk profil och vill lära barnen att ta ansvar för sin närmiljö. Som en del i detta driver Gnistan också ett kaninhotell. Genom den dagliga skötseln av kaninerna lär sig barnen att ta ansvar och samarbeta.

Gnistan startades 1997 av Safija Imsirovic och 22 år senare är det fortfarande hon som leder verksamheten. Hon har under årens lopp tagit emot de prestigefyllda certifieringarna Grön flagg och Fairtrade samt en rad andra priser, hyllningar och erkännanden för verksamheten. Dessutom har hon haft besök av kronprinsessparet Victoria och Daniel. Allra stoltast blev hon 2002 då hon belönades med Malmö stads miljöpris "för berömvärda insatser som initiativtagare till öppen fritidsverksamhet och grannsamverkan för en bättre boendemiljö i Augustenborgsområdet". Safija startade Gnistan då hon utifrån samtal med boende i området såg ett behov av aktiviteter för barn och ungdomar till arbetslösa föräldrar. På grund av föräldrarnas arbetslöshet fick inte barnen tillgång till fritidsverksamhet. Därmed blev det samtidigt svårare för föräldrarna att söka jobb och studera. Gnistan startades som svar på detta behov (Imsirovic, 2017).

Under de första två åren bedrevs verksamheten ideellt men med stöd av MKB som bidrog med en lokal. 1999 fick Gnistan projektpengar som fritidsverksamhet i Unga Örnars regi. Några år senare, 2003, införlivades Gnistan i Malmö stad när Fosie stadsdelsförvaltning övertog ansvaret för drift och ekonomi. Därefter kom Gnistan att ha flera olika organisatoriska tillhörigheter. Det började inom individ- och familjeomsorgen men övergick 2011 till Fosies barn och ungdomsverksamhet med koppling till Augustenborgsskolan. Efter bildandet av stadsområdesnämnder och grundskolnämnder 2013 bröts kopplingen till Augustenborgsskolan och Gnistan kom att ingå i den nybildade stadsområdesnämnden Söders avdelning för områdesutveckling. Inför avskaffandet av stadsområdena och återinförandet av facknämnder blev det oklart var Gnistan skulle höra hemma. Det gjordes en utredning 2015 och den kom fram till att Gnistan kanske borde avvecklas i kommunal regi. Det uppstod en oklarhet om vad som skulle göras och som en följd av besparingskrav tog stadsområdesnämnd Söder beslut 2015 om att halvera budgeten för Gnistan. Ytterligare nedskärningar gjordes året därpå och i oktober 2016 begränsades öppethållandet till dagtid. I en tidningsartikel protesterade Safija och hon menade att kvällsöppet var nödvändigt: "Det var syftet från början att det ska vara öppet på kvällstid. Idén var att föräldrarna skulle ha möjlighet att studera eller jobba." (SDS, 2 oktober 2016).

Inte bara Safija protesterade mot de stora nedskärningarna. Fyra tidigare Gnistan-barn skrev en debattartikel i Sydsvenskan (SDS, 9 oktober 2016). De berättade om hur de hade träffats som barn på Gnistan i slutet av 1990-talet. "För oss var Gnistan en plats där vi blev sedda och inkluderade, en plats där vi fick träffa vuxna och barn från livets alla hörn; nyanlända, nyutbildade, trasiga, till synes hela. Där blev vi motiverade och utmanade." De beskrev Gnistan som "ett interaktivt mikrokosmos" med över hundra inskrivna barn från nio olika nationaliteter. Alla sammanlänkas de på Gnistan "som en given plats i Augustenborgs sociala nätverk. Det är ett ställe utan dess like i 
Sverige." De förklarade hur Gnistan hade hamnat mellan stolarna i den kommunala byråkratin och hur "nedskärningarna bidrar till en reproducerande cirkel av exkludering från samhället med risk för utanförskap och att barnen på olika sätt hamnar i riskzonen för kriminalitet och gängbildning".

Nedskärningarna av Gnistan och hotet mot verksamheten väckte ett stort engagemang. Det ledde till att Föreningen Gnistan bildades den 7 september 2017. Några månader senare hade föreningen skrivit avtal med kommunen om att överta verksamheten, vilket formellt sett skedde den 1 november 2017. Avtalet innebär att kommunen betalar ett årligt bidrag till föreningen och utan det skulle verksamheten inte kunna fortsätta.

Men hur kunde kommunen vara nära att lägga ned en så framgångsrik, omtyckt och prisad verksamhet? Vår tolkning är att Gnistan var mycket nära att bli ett offer för det problemorienterade förhållningssättet. Några av de exempel vi tidigare har tagit upp - och i synnerhet satsningen på CTC - kan tyda på att detta förhållningssätt verkar få en ny spridning i de kommunala förvaltningarna, vilket i sig alltså inte är något nytt men blir anmärkningsvärt i relation till den nyligen genomförda Malmökommissionen och dess rekommendationer.

\section{Problem och förändringsobjekt}

Vad går man då miste om när verksamheter som Gnistan behandlas utifrån ett problemorienterat förhållningssätt? Svaret måste nog bli: alltihop! Utifrån ett problemorienterat förhållningssätt skulle Gnistan inte ens ha varit intressant att starta. Det är ju nämligen inte några uppenbara problem, såsom våld, kriminalitet eller otrygghet $\mathrm{i}$ området, som har motiverat satsningen på denna verksamhet. Det är överhuvud taget inget observerbart fenomen, inget som tränger sig på och skapar rubriker i massmedia. Det som låg till grund för startandet av Gnistan var snarare ett behov, närmare bestämt föräldrars behov av tid till att söka jobb och vidareutbilda sig. Det kan dock säkert bli ett problem för enskilda föräldrar om detta behov inte tillgodoses. För myndigheterna kan det bli ett problem om dessa människor inte förvärvsarbetar och därmed kanske inte betalar skatt utan lever på bidrag. Då kanske man rentav får för sig att dessa människor utgör problemet och en sådan slutsats skulle mycket väl kunna motiveras utifrån ett problemorienterat förhållningssätt.

Men det förhållningssättet har man inte haft på Gnistan. De personer som Gnistan vänder sig till betraktas inte som aktiva företrädare av problem. De ses istället som drabbade av ett problem vilket de inte i någon mening kan sägas bära skulden till. Men de betraktas inte heller som passiva företrädare av ett problem i den meningen att de saknar något som Gnistan ska hjälpa dem att skaffa sig. De ses t ex inte som kraftlösa eller okunniga. Snarare får Gnistan dem att framstå som företrädare av potentialer, vilka de utan Gnistan förhindras från att aktualisera. De skulle säkert kunna jobba och försörja sig. De har säkert många erfarenheter och kunskaper men de förhindras från att använda dessa på arbetsmarknaden. Med den betydelse som förvärvsarbetet 
har i samhället kan de därmed inte heller fullt ut utöva sitt samhällsmedborgarskap. Orsaken till detta - det som förhindrar dem - är det problem som Gnistan bidrar till att lösa. För att förstå det krävs det kunskap om hur samhället fungerar. Det krävs att man förstår sambandet mellan att arbetslösa inte får ha sina barn på fritids och deras fortsatta arbetslöshet.

Gnistan kan därmed också sägas ha ett annat förändringsobjekt än vad man skulle ha utifrån ett problemorienterat förhållningssätt. Det är inte enskilda individer som ska förändras eller individens närmaste sammanhang med familj osv. Gnistans förändringsobjekt kan istället sägas vara samhällsystemen, närmare bestämt skola och arbetsmarknad. Det är visserligen inget av dessa systems funktionssätt som förändras men däremot den strukturella kopplingen dem emellan genom att Gnistan kompletterar dem. Gnistan kan sägas placera in sig mellan dessa system. Utan Gnistan existerar det en selektivitet i denna strukturella koppling som innebär att arbetslösa föräldrar missgynnas. Eftersom dessa föräldrar också på Augustenborg vanligtvis har varit invandrare har de också svårt att få gehör för detta behov. Men allt detta blir helt omöjligt att förstå utifrån ett problemorienterat perspektiv. Problemet visar sig inte genom några självklara regelbundna samband mellan observerbara fenomen. Det krävs en förståelse av det Michael Marmot kallar "causes of the causes", vilket vi här har tolkat som de i samhällssystemen inneboende potentiella orsakerna.

Utifrån det förhållningssätt som Gnistan ger uttryck för betraktas orsakerna istället som samhälleliga. Det är en grundläggande skillnad jämfört med en satsning som drivs av ett problemorienterat förhållningssätt såsom, menar vi, CTC. Att föräldrarna inte får de möjligheter som behövs för att de ska kunna söka jobb, vidareutbilda sig och ta plats i samhället som medborgare beror på samhällssystemens sätt att fungera. Effekterna av dessa orsaker är de symptom som Gnistan vill bidra till att lösa.

\section{Gnistans potentialer}

När Gnistan griper sig an symptomproblemen så innehåller lösningen en barnverksamhet med hög kvalitet. I Gnistans vision har det formulerats som "ett lyssnande och demokratiskt socialt sammanhang". Man kan fråga sig var det i dagens samhälle finns sådana sammanhang. Är det inte ett problem att de saknas? I så fall bidrar Gnistan till att lösa även detta problem. Enligt Gnistans visionsdokument möjliggör Gnistan "ett allsidigt, relationellt och bildande lärande". Dessa två hörnpelare i visionen innebär att Gnistan fullgör en uppgift som enligt Läroplanen borde åligga skolan men som skolan av olika skäl ofta har svårt att lyckas med (inte av bristande vilja men på grund av hög arbetsbelastning för lärarna, ett betygssystem som inte tycks stödja denna typ av lärande samt att resurser saknas för att hantera sådana sociala problem som inte primärt är skolans uppdrag men som ohjälpligt tar sig in i dess vardag). Det är dock inte för att möjliggöra ett sådant lärande som Gnistan har skapats. Det uttalade syftet med Gnistan har inte varit att utgöra en modell för hur skolan borde fungera. Ändå menar vi att Gnistan lyckas med detta. När väl det har sagts måste genast en viktig 
skillnad i förutsättningarna nämnas. På Gnistan sätts det inga betyg. Detta visar sig i själva verket vara till stor fördel för möjligheterna att utveckla verksamheten på ett sätt som faktiskt stämmer överens med den kunskapssyn som Läroplan för grundskolan förespråkar.

Man skulle kunna säga att Gnistan löser tre problem till priset av ett. En sådan förenklad beskrivning fångar in själva Gnistan-konceptet, dvs den potential som Gnistan utgör. Gnistan-konceptet utgör en potential för att kunna lösa symptomproblemet med föräldrars svårigheter att söka jobb, samtidigt som det möjliggör en fördjupad kunskap om föräldrars och barns erfarenheter och vardagsvillkor. Konceptet skulle kunna vidareutvecklas genom att sjösättas i även andra stadsdelar.

Man kan emellertid också fråga sig om Gnistan på Augustenborg verkligen aktualiserar sin fulla potential. Vi skulle vilja peka på en aspekt som inte aktualiseras, nämligen följande. Det problem som Gnistan bidrar till att lösa är föräldrarnas svårigheter med att söka jobb och vidareutbilda sig, vilket i sig kan ses som ett symptomproblem. Det förorsakas av samhällssystemens sätt att fungera; mer specifikt den strukturella kopplingen dem emellan. Detta förhindrar för föräldrarna att söka jobb och utbilda sig. Häri ligger alltså en orsak till symptomproblemet. Så länge den består kommer det att drabba dessa föräldrar. Men skulle inte Gnistan kunna bidra till att lösa även detta orsaksproblem? Det är den stora fråga som väcks och vi menar att det faktiskt finns skäl att svara ja på den. Här finns den del av Gnistan-konceptets potential som ännu inte har aktualiserats.

Vad skulle då en aktualisering av denna potential innebära och hur skulle det gå till? Jo, det skulle kunna ske genom att den erfarenhet som Gnistan har blivit en samlingsplats för bearbetades till kunskap och spreds vidare. Vad vi menar är att det på Gnistan ges uttryck för många erfarenheter av det symptomproblem som dagens Gnistan bidrar till att lösa. Symptomproblemen handlar om hur föräldrar och barn har det på Augustenborg. De flyttar in och de flyttar ut. De flyttar runt. Det är trångbott. På Gnistan får man höra mycket om detta. Dessa erfarenheter skulle kunna tas till vara och bearbetas till kunskap genom kunskapsallianser, dvs den form för skapandet och utvecklandet av kunskap som Malmökommissionen framhöll i sin andra övergripande rekommendation. I en sådan kunskapsallians skulle då företrädare för dessa erfarenheter och olika kunskaper delta, även forskare. Syftet skulle vara att skapa kunskaper om både symptom och orsaker. Kunskaperna om symptomen skulle handla om hur befolkningen faktiskt har det. Kunskaperna om orsakerna skulle svara på frågor om vad det är i samhällets system, organisationsformer, rutiner, regler, förhållningssätt, tankesätt och kulturer som gör att människor måste ha det så här. Denna kunskap skulle sen kunna användas för att förändra systemen. 


\section{REFERENSER}

Alwall, J. \& Hellberg Lannerheim, P. (2018). Brightful in Malmö: Finding one’s own way. I: T. Sirovátka \& H. Spies (Eds.). Effective Interventions for Unemployed Young People in Europe. Social Innovation or Paradigm Shift? London/New York: Routledge.

Fairclough, N. (2000). New Labour, New Language? London: Routledge.

Forward Malmö. (2019.) Om Forward Malmö. https://www.facebook.com/pg/Forward-Malmo-1007641592739530/about/?ref=page_internal (Hämtad 2019-09-09)

Furlong, A. \& Cartmel, F. (2007). Young people and social change: new perspectives. 2. ed. Buckingham: Open University Press.

Imsirovic, S. (2017). Gnistans ekologi - en fallstudie i samspelet mellan individ och miljö. Masteruppsats i pedagogik, Malmö högskola.

Levitas, R. (2005). The Inclusive Society? Social Exclusion and New Labour. Basingstoke: Macmillan.

Malmö stad. (2017). CTC - Sex delar som bildar en unik helhet. https://malmo.se/ download/18.a13b8a215b9c0c8d41a8821/1493715264713/ctc-folder-17-03-14.pdf (Publicerad 2017-03-14, hämtad 2019-09-09).

Malmö stad. (2018.) Malmö stad och näringslivet inleder samarbete för utveckling av framtida urbana innovationer. http://www.mynewsdesk.com $/ \mathrm{se} / \mathrm{malmo} /$ pressreleases/malmoe-stad-och-naeringslivet-inleder-samarbete-foer-utveckling-av-framtida-urbana-innovationer-2402629 (Publicerad 2018-02-02, hämtad 2019-09-09).

Malmö stad. (2019). CTC - Communities That Care. https://malmo.se/ctc (Hämtad 2019-09-09).

Malmöandan. (2019). Malmöandan - i samverkan för demokrati, delaktighet och jämlikhet. http://www.malmoandan.se/ (Hämtad 2019-09-09).

Marshall, T.H. (1950). Citizenship and Social Class. Cambridge: Cambridge University Press.

Robotham, D. (2005). Culture, Society and Economy: Bringing Production Back In. London: SAGE.

Roumeliotis, F. (2016). Ideological Closure: Drug Prevention in a Post-political Society. Stockholm studies in sociology 63. Stockholm: Stockholm University.

Schierup, C-U. (2015). Migration, medborgarskap och social exkludering - ett europeiskt dilemma. I: M. Darvishpour \& C. Westin (red.). Migration och etnicitet: Perspektiv på ett mångkulturellt Sverige. Lund: Studentlitteratur.

SDS, 2 oktober 2016. Kommunen halverar hyllad barnverksamhet.

SDS, 9 oktober 2016. Vår mötesplats Gnistan behövs i ett område med langare och utsatthet. 
Stigendal, M. (2016). Samhällsgränser. Ojämlikhetens orsaker och framtidsmöjligheterna i en storstad som Malmö. Stockholm: Liber.

Stigendal, M. (2018). Combatting the Causes of Inequality Affecting Young People Across Europe. Croydon: Routledge.

Stigendal, M. \& Novy, A. (2018). Founding transdisciplinary knowledge production in critical realism: implications and benefits. Journal of Critical Realism 17:3, 203-220.

Stigendal, M. \& Östergren, P-O (2013). Malmös väg mot en hållbar framtid: hälsa, välfärd och rättvisa. Malmö: Malmö stad.

Strandlund, E., Bernhard-Oettel, C. \& Låstad, L. (2018). Otrygghet - oro - ohälsa? En studie bland handelsanställda. Arbetsmarknad \& Arbetsliv 24:1-2.

WHO (World Health Organization) (2008). Closing the gap in a generation: health equity through action on the social determinants of health. Final report of the Commission on Social Determinants of Health. Geneva: World Health Organization. 


\title{
Brandväggsprincipen - att säkerställa papperslösa barn och ungas rättigheter $\mathrm{i}$ Malmö
}

\author{
Linus Hermansson \\ Jacob Lind \\ Hanna Scott ${ }^{1}$
}

\section{INTRODUKTION}

I Malmö lever ett okänt antal barn och unga i papperslöshet med ett ständigt närvarande hot om utvisning genom deportation hängande över sig. FN:s allmänna förklaring om de mänskliga rättigheterna och FN:s barnkonvention ålägger uttryckligen stater att garantera grundläggande rättigheter för barn, oavsett legal status. Det innebär att barn utan laglig rätt att vistas i landet måste garanteras tillgång till de rättigheter som föreskrivs här och nu, men det innebär också att det behöver finnas vägar för dem och deras familjer att få en mer reguljär tillvaro i Sverige. Just deras utvisningsbarhet (se Sager, Holgersson och Öberg, 2016), den ständiga rädslan och osäkerheten, påverkar allvarligt deras rätt till liv och utveckling, inklusive barnets fysiska, mentala, andliga, moraliska, psykologiska och sociala utveckling (UNCRC, 2003).

Syftet med det här kapitlet är att diskutera hur brandväggsprincipen - åtskiljandet mellan tillhandahållandet av rättigheter och inre gränskontrollarbete - kan bidra till att papperslösa barn i större grad kan tillgodogöra sig sina rättigheter i Malmö. Vi som skriver det här kapitlet har alla genom praktiskt socialt arbete och forskning följt många barn och unga som lever i papperslöshet. I texten utgår vi ifrån både våra egna erfarenheter liksom barnen och de ungas berättelser när vi diskuterar brandväggsprincipen som en metod för att säkra tillgång till grundläggande mänskliga rättigheter.

I det följande ger vi först en bakgrundsbeskrivning av utvecklingen i Malmö under de senaste åren och diskuterar därefter brandväggsprincipen. Denna princip används sedan för att analysera två händelser i Malmö som belyser hur papperslösa barn under

I Alla författare har bidragit lika mycket till texten och listas i bokstavsordning. 
senare år fått allt svårare att tillgodogöra sig sina rättigheter. Händelserna visar på vikten av att inte bara tillgodose papperslösa barn och ungas rättigheter, utan att också praktikerna genom vilka dessa rättigheter tillgodoses - och platserna som möjliggör detta - skyddas från gränspolisens arbete. Vi avslutar kapitlet med en diskussion om vilka konsekvenser brandväggsprincipen kan ha för rättighetsarbete med barn i papperslöshet som bor i Malmö.

\section{MALMÖ I MIGRATIONSPOLITISKT FOKUS}

Under hösten 2015, då antalet asylsökande i Sverige ökade markant, spelade Malmö en viktig roll som transitstad, och som brännpunkt för den snabba vändning som då skedde i svensk migrationspolitik (Magnusson, 2015). I denna text vill vi uppmärksamma hur Malmö fortsatt är en central plats för de politiska processer genom vilka papperslösa barn och ungas utsatthet ökar till följd av den repressiva migrationspolitik som har genomförts i Sverige och Europa sedan 2015, tillsammans med de restriktioner i välfärden som genomförts inom asylmottagandet och socialtjänstens arbete. Lagen om tillfälliga begränsningar av möjligheten att få uppehållstillstånd i Sverige som antogs 2016 innebar bland annat tillfälliga uppehållstillstånd, begränsad rätt till familjeåterförening och en ändrad skrivning när det gäller barns rätt till uppehållstillstånd på grund av särskilt ömmande omständigheter ${ }^{2}$. Barnombudsmannen har kallat den tillfälliga utlänningslagen rent "barnfientlig" (Barnombudsmannen, 2016). Ändringen av skrivningen om särskilt ömmande omständigheter har inneburit kraftigt minskade möjligheter för särskilt sårbara barn på flykt att få stanna i Sverige.

I Malmö har de migrationspolitiska förändringarna bland annat yttrat sig genom att gränspolisen har begärt ut kontaktinformation till papperslösa barnfamiljer från socialtjänsten, gjort tillslag mot Svenska kyrkans familjeläger samt genomfört inre utlänningskontroller i direkt anslutning till verksamheter samarrangerade av staden som riktats till papperslösa unga. Gränspolisen i region Syd har själva i media uttryckt att de under de senaste åren blivit "ett naturligt inslag i dagens samhälle" (Landelius, 2019). Dessa händelser utspelar sig mot en bakgrund av ett hårdnande klimat generellt mot utsatta grupper i samhället och har bidragit till att skada tilliten bland papperslösa barn och unga gentemot institutioner och organisationer. Samtidigt har både stödet till asylsökande nationellt och socialtjänstens bedömningar lokalt i biståndsfrågor som rör barn och unga utan papper stramats åt. En uppföljande studie från Röda Korset visar att sådana förändringar drabbar barn särskilt hårt och orsakar stort psykiskt lidande (Beskow, 2019).

Malmö har som stad, till följd av initiativ från civilsamhälle, tjänstemän och politiker, genom åren gått i täten för att garantera rättigheter för papperslösa barn och

2 För en översikt av den tillfälliga lagen, se:

https://www.farr.se/sv/att-soeka-asyl/den-tillfalliga-lagen 
unga. Papperslösa barn har kunnat gå i skola och förskola i Malmö och Skåneregionen skapade riktlinjer för kostnadsfri vård till papperslösa långt innan lagarna om skolgång och vård för papperslösa trädde i kraft 2013. Det finns flera möjligheter för barn och unga utan papper att delta i fritidsaktiviteter och de kan låna böcker på biblioteket. År 2013 beslutade kommunfullmäktige i Malmö att barn utan papper skulle beviljas försörjningsstöd som alla andra barn i socialtjänsten (se Nordling, 2017). Unga utan papper kunde genom riktlinjerna beviljas nödstöd till mat för dagen. Detta systematiserade den hjälp som socialtjänsten i Malmö även tidigare i vissa fall beviljat papperslösa barn och unga utifrån individuell bedömning. Dessa lokala initiativ har ofta motiverats av barnets bästa och principen om allas lika värde och ger uttryck för att Malmö varit en plats där det funnits en strävan hos staden att förverkliga globala människorättsliga åtaganden på lokal nivå genom politiska och kommunala beslut och initiativ.

Det finns därför ett stort behov av att både försvara och utvidga de rättigheter som papperslösa barn redan har, samt att, inte minst arbeta för att återskapa de rättigheter som finns på papperet men som urholkats i praktiken. Det vi särskilt vill diskutera i det följande är just hur arbetet med att få rättigheter att fungera i praktiken måste åtföljas av processer som säkerställer att papperslösa barns rättigheter ska kunna tillgodoses på ett säkert sätt genom upprättandet och upprätthållandet av "brandväggar".

\section{VAD INNEBÄR BRANDVÄGGSPRINCIPEN?}

Brandväggsprincipens syfte är att reglera relationen mellan migrationskontrollerande myndigheter och institutioner som tillgodoser rättigheter så att barn och unga utan papper inte utsätter sig för en ökad risk för deportation när de tar del av sina grundläggande rättigheter. Vi har tillsammans med ett antal forskare formulerat följande definition av brandväggsprincipen (som också visualiseras i Bild 1):

Ingen information som samlats in i syfte att möjliggöra tillgodogörandet av mänskliga rättigheter får efterfrågas av, delas med eller användas av myndigheter ansvariga för migrationskontroll i syfte att verkställa en av- eller utvisning. När migranter upprätthåller sig inom, eller i direkt närhet till, religiösa, privata och offentliga institutioner som tillgodoser mänskliga rättigheter ska det vara förbjudet att kontrollera eller frihetsberöva dem på basis av deras migrationsrättsliga status. (Hermansson et al., kommande, vår översättning)

Vår definition är en precisering av en princip som fastslagits av ett antal internationella institutioner, bland annat FN:s barnrättskommitté (UNCRC och CMW, 2017, sektion 17), och är en utveckling av filosofen Joseph Carens (2013) diskussion av begreppet (se även Crépeau och Hastie, 2015; Lundberg, Gruber och Righard, 2018). Definitionen innehåller två dimensioner; för det första ett skydd mot utlämnande av 
information och för det andra ett skydd av vissa platser och rum från gränspolisarbete (se Bild 1). Båda dessa dimensioner är nödvändiga för att människor utan papper ska ha möjlighet att tillgodogöra sig sina lagstadgade och konventionsgrundade rättigheter i praktiken.

\section{Institutioner som till- godoser rättigheter}

Socialtjänst, skolor, vărdinsatser, ideella organisationer, religiösa samfund etc.

I. Förbjudna att dela information som samlats in för att tillgodose rättigheter

2. Skyddade mot inre utlänningskontroller inom och kring institutioner som tillgodoser rättigheter

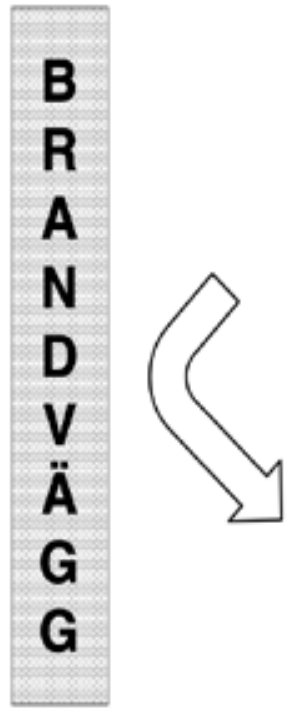

\section{Kontrollmyndigheter}

Gränspolisen, Migrationsverket etc.

\section{Förbjudna att efterfrảga in- formation som samlats in for att tillgodose rättigheter \\ 2. Förbjudna att genomfora inre utlänningskontroller inom och kring institutioner som tillgodoser rättigheter}

\section{Bild 1. Brandväggsprincipen (översatt från Hermansson et al., kommande)}

Även om begreppet brandvägg kan te sig nytt i en svensk kontext, har vi redan i Sverige ett antal mer eller mindre starka "brandväggar" i form av sekretessbestämmelser mellan och inom olika myndigheter såsom socialtjänst, skola, polis och vården som förhindrar att personlig eller känslig information delas. Dessa brandväggar är till för att skydda den personliga integriteten för alla människor och har en särskilt avgörande betydelse för barn och unga utan papper. Brandväggar i form av sekretessbestämmelser inom verksamheter som tillgodoser rättigheter relaterar främst till den första dimensionen av brandväggsprincipen. I samband med att lagarna om rätt till vård och skola för papperslösa barn från 2013 togs fram diskuterades även frågan om hur barn utan papper skulle våga tillgodogöra sig dessa rättigheter utan rädsla för migrationskontroll. Både vården och skolan utövar visst myndighetsarbete och har en skyldighet att samarbeta med polisen under vissa omständigheter. De statliga utredningar som låg till grund för lagarna om rätten till vård (SOU 2011:48, 2011) och skolgång (SOU 2007:34, 2007) slog båda fast att patientsekretessen och skyddet av elevers personuppgifter var starkt i Sverige sedan tidigare och inte behövde kompletteras med särskilda regler för papperslösa patienter och elever.

Dessa regelverk utgör i praktiken en form av informationsskyddande brandväggar då de ger vården och skolan vägledning kring att skydda papperslösa från inre gränskontrollarbete. Skolverket (2015) har bland annat lyft fram hur skolan kan 
hantera papperslösa elevers personuppgifter på samma sätt som de gör i relation till elever med skyddad identitet. Patientskyddet innebär bland annat att när polisen ringer en vårdinrättning i ett verkställighetsärende får de inte ställa generella frågor om huruvida det finns några papperslösa personer $i$ allmänhet inskrivna på avdelningen, utan behöver namnge personen de frågar efter för att få veta om denne vårdas där. Region Skåne har tydliga riktlinjer ${ }^{3}$ som förskriver att vårdpersonalen ska "motringa", det vill säga be att få ringa tillbaka, vid förfrågningar från polismyndigheten för att bevara den strikta sekretessen. Skolverkets rekommendationer, patientsekretessen så som den är utformad i vårdens regelverk och praktiken att "motringa" är olika former för hur brandväggsprincipen kan komma till uttryck i praktiken på olika nivåer i rekommendationer, regelverk och praktisk handling.

Den andra dimensionen av brandväggsprincipen som berör skyddet av olika platser kommer också redan till uttryck på olika sätt i myndighetsarbete. Till exempel reglerar polisens egna förskrifter gränspolisens verkställighetsarbete och begränsar gränspolisens möjligheter att eftersöka eller hämta barn vid i eller i anslutning till en skola där hen är elev för att genomföra en utvisning (RPSFS, 2014). Dessa regler utgör dock ett relativt svagt skydd då de förvisso är bindande, men inte utgör ett absolut hinder för gränspolisen. Det är även viktigt att i detta sammanhang påpeka att brandväggsprincipen inte hindrar polisen från att bedriva brottsutredande arbete. För att polisen ska ha trovärdighet inom den brottsförebyggande och brottsutredande delen av sitt arbete behövs dock också brandväggar mellan de olika delarna av polisväsendet, vilket finns i flera andra länder. I Malmö möter vi ensamkommande unga och andra som lever utan papper som är brottsutsatta men inte vågar gå till polisen. Om någon utsätts för våld $\mathrm{i}$ en nära relation, tvingas ha sex mot ersättning eller utsätts för något annat brott, behöver en anmälan kunna göras utan att brottsoffret därigenom utsätter sig för risken att utvisas. För att alla som bor i Malmö ska kunna känna sig trygga, måste därför alla som utsätts för våld eller andra brott ha samma möjligheter att anmäla och få stöd från rättsvårdande myndigheter, som polisen och socialtjänsten. Dessa rättigheter regleras inte bara i nationell lagstiftning, utan återfinns även inom EU rätten i form av EU:s brottsofferdirektiv som förordar alla brottsutsattas lika rättigheter, oavsett migrationsrättslig status, en skrivning som skulle kunna ligga till grund för framtida brandväggsarbete.

En viktig aspekt av brandväggar är att de konstrueras och upprätthålls på olika nivåer i samhället samtidigt. Tabell 1 visar på hur detta går till.

Arbetet med att skapa och upprätthålla brandväggar sker till stor del i praktiken på individnivå baserat på personliga attityder hos professionella som bedriver rättighetsarbete för och med människor utan papper. Brandväggar uppkommer dessutom framför allt underifrån, genom praktiskt socialt arbete och följs sedan eventuellt av politiska initiativ. I arbetet som föregick lagen om vård till papperslösa från 2013 var argument gällande vårdpersonals professionsetik viktiga (SOU 2011:48, 2011).

\footnotetext{
$3 \mathrm{https}: / /$ vardgivare.skane.se/patientadministration/vard-av-personer-fran-andra-lander/ migration-asyl/sekretesshantering/
} 
Tabell 1. Brandväggsprincipen på olika nivåer (anpassad och översatt från Hermansson et al., kommande)

\begin{tabular}{|c|c|c|}
\hline & $\begin{array}{l}\text { Institutioner som } \\
\text { tillgodoser rättigheter }\end{array}$ & Kontrollmyndigheter \\
\hline $\begin{array}{l}\text { Personliga } \\
\text { attityder }\end{array}$ & $\begin{array}{l}\text { Individer navigerar i ett } \\
\text { etiskt dilemma som } \\
\text { exempel genom att applicera } \\
\text { professionsetiska principer }\end{array}$ & $\begin{array}{l}\text { Individer navigerar i ett } \\
\text { etiskt dilemma }\end{array}$ \\
\hline Informell policy & $\begin{array}{l}\text { Oskrivna praktiker på } \\
\text { lokal nivå som förhindrar } \\
\text { informationsdelning }\end{array}$ & $\begin{array}{c}\text { Oskrivna praktiker på } \\
\text { lokal nivå som förhindrar } \\
\text { metoder för gränspolisarbete }\end{array}$ \\
\hline Formell policy & $\begin{array}{l}\text { Nedskrivna och uttalade policys } \\
\text { som hindrar informationsdelning }\end{array}$ & $\begin{array}{l}\text { Nedskrivna interna policys } \\
\text { som förhindrar specifika } \\
\text { metoder för gränspolisarbete }\end{array}$ \\
\hline $\begin{array}{l}\text { Nationell och } \\
\text { internationell } \\
\text { lag }\end{array}$ & $\begin{array}{l}\text { Nationell och internationell lag som } \\
\text { direkt förbjuder informationsdelning }\end{array}$ & $\begin{array}{c}\text { Nationell och internationell lag } \\
\text { som direkt förbjuder specifika } \\
\text { metoder för gränspolisarbete }\end{array}$ \\
\hline
\end{tabular}

Hur stark ställning yrkesetiken har inom läkarkåren visades av en studie om svenska läkares inställning till vård för papperslösa, där nästan alla deltagande läkare uppgav att de gav vård till patienterna och skyddade deras personuppgifter trots att de, felaktigt, trodde att de bröt mot lagen när de gjorde så eftersom de inte kände till papperslösa personers rätt till vård (Greenbrook, 2019). Vårdarbetares professionsetik är särskilt stark och etablerad, men liknande professionsetiska ställningstaganden kan ses - och testas av den migrationspolitiska utvecklingen - också hos andra grupper. Till exempel är lärare en särskilt aktuell yrkeskategori utifrån de krav som den nya gymnasielagen ställer på de unga som beviljats uppehållstillstånd på grund av studier. Upprätthållandet av brandväggsprincipen kan beskrivas som en ständigt pågående förhandling mellan olika aktörer. Vissa av oss författare har till exempel tidigare medverkat vid informella möten mellan rättighetsbaserade organisationer och Gränspolisen där de senare redogjort för sina informella policys om att de inte eftersöker barn i skolor, sjukhus eller kyrkor. Migrationspolitiska förändringar som bland annat manifesterades i ett regeringsuppdrag att öka antalet verkställigheter av utvisningsbeslut har dock bidragit till att gränspolisen i region Syd under slutet av 2016 började eftersöka människor utan papper inom verksamheter som tidigare antagits vara trygga och vars uttalade syfte är att ge hjälp och stöd till människor i utsatthet, däribland till de som lever i Malmö utan papper. De två exemplen i de följande avsnitten visar på denna utveckling och tydliggör att papperslösa barn och ungas jämlika tillgång till grundläggande rättigheter i praktiken under de senaste åren blivit svårare att uppnå, varför också behovet av brandväggar blivit allt tydligare. 
Ett exempel på en formell policy är Regions Skåne riktlinjer om hur papperslösa patienters personuppgifter ska hanteras som syftar till att komplettera och klargöra hur den redan starka patientsekretessen fungerar i relation till människor som lever utan uppehållstillstånd. Ett annat exempel är Skolverkets (2015) ovan nämnda rekommendationer för papperslösa elever. Även om dessa riktlinjer inte är formell lag så har de stor tyngd för hur det praktiska arbetet i myndigheter och organisationer går till och kan inte förändras lika enkelt som informella överenskommelser eller praktiker.

Nationell lag och internationell rätt är på många sätt de områden där de starkaste uttrycken för brandväggar kan iakttas och i svensk lagstiftning finns som tidigare nämnts långtgående sekretessbestämmelser som innefattar alla patienter och elever, även de utan papper. Stödet i internationell rätt för brandväggar är också starkt (ECRI, 2016; EU FRA, 2013; UN General Assembly, 2017, § 67; UNCRC och CMW, 2017, sektion 17), vilket i Sverige skulle kunna leda till att stärka papperslösa barns rättigheter när FN:s barnkonvention år 2020 planeras bli lag. Det är viktigt att komma ihåg dock att brandväggar framför allt uppkommer underifrån, genom praktiskt socialt arbete och följs sedan eventuellt av politiska initiativ, inte tvärt om.

Sammantaget finns det redan brandväggar med varierande styrka i Sverige och vår diskussion är inte uttömmande utan vi har endast redogjort för några centrala exempel. Vi menar att brandväggsprincipen kan spela en avgörande roll för att tjänstemän och beslutsfattare på olika nivåer ska kunna orientera sig i relation till motstridiga uppdrag och budskap när migrationskontroll och välfärdssystem allt mer kommit att överlappa varandra.

\section{GRÄNSPOLISEN BEGÄR UT INFORMATION OM PAPPERS- LÖSA FAMILJER FRÅN SOCIALTJÄNSTEN}

Vårt första exempel som synliggör betydelsen av brandväggar berör den första dimensionen av brandväggsprincipen om utlämnande av information. Som en direkt följd av regeringens direktiv om att "avsevärt öka" (Mikkelsen, 2016) andelen utvisningar bestämde sig Polismyndigheten, Gränspolissektionen Syd, i slutet av 2016 för att använda sig av en dessförinnan aldrig tillämpad paragraf i Utlänningslagen kapitel 17 som bryter socialtjänstens annars strikta sekretess. I november 2016 skickade gränspolisen en begäran till Socialtjänsten i samtliga stadsområdesförvaltningar i Malmö stad om adress- och kontaktuppgifter till 200 namngivna personer med utvisningsbeslut. Kort därefter genomfördes utvisningar av fyra barnfamiljer som frihetsberövats av gränspolisen till följd av att socialtjänsten lämnat ut familjernas hemadresser till myndigheten. Beslutet fick långtgående negativa konsekvenser också för andra papperslösa personer i Malmö. Det har påverkat socialtjänstens rutiner och i stor utsträckning begränsat myndighetens möjligheter att hjälpa gruppen papperslösa barn 
och unga, då varje ny kontakt med en papperslös person i behov av hjälp och stöd nu behöver inledas med att handläggaren förklarar socialtjänstens uppgiftsskyldighet till gränspolisen.

$\mathrm{Nu}$, nästan tre år senare, ser vi som möter barn och unga i papperslöshet de fortsatta negativa effekterna av gränspolisens beslut att använda sig av den sekretessbrytande bestämmelsen. Användandet av uppgiftsskyldigheten har blivit ett verktyg i verkställighetsarbetet i region syd och har använts av gränspolisen för att begära ut uppgifter om mer än ett fyrtiotal papperslösa individer under 2018 och hittills under 2019 (enligt uppgift från socialtjänsten). Vi ser hur gränspolisens arbete i viss mening gjort socialtjänsten till gränspolisens förlängda arm och att detta allvarligt skadat förtroendet bland barnfamiljer och unga utan papper för socialtjänsten, såväl som för svenska myndigheter i stort. Trots detta fortsätter barn och unga utan papper att vända sig till socialtjänsten, då de saknar andra möjligheter till försörjning och som regel befinner sig i en oerhört utsatt livssituation. Ur ett barnskyddsperspektiv har socialtjänsten vid en orosanmälan nu betydligt sämre möjligheter att hjälpa ett våldsutsatt barn eftersom föräldrarna riskerar att hålla sig undan myndigheter. Risken finns att skolpersonal blivit mindre benägna att göra orosanmälningar om de misstänker att en elev utsätts för våld i hemmet, då de inte vill riskera att detta leder till utvisning. Det är svårt att se hur detta går ihop med regeringens avsikt att införa regleringar för att stärka skyddet för alla barn som blir utsatta för och bevittnar våld.

Skåne Stadsmissions barn- och ungdomsverksamhet Unga Forum är och har under en längre tid varit en central punkt för socialt utsatta barnfamiljer och ensamkommande barn och unga. Det är en trygg plats med låga trösklar där jurister och socionomer arbetar tillsammans med juridiskt, praktiskt och socialt stöd. Stadsmissionen hjälpte de barnfamiljer som berördes av polisens agerande och kritiserade kraftigt gränspolisens agerande i media. Genom att snabbt mobilisera råd och stöd till berörda familjer, upprätta en dialog med socialförvaltningen och ta fram informationsmaterial på flera olika språk kunde Stadsmissionen stödja både de familjer som frihetsberövats och de med en pågående kontakt med socialtjänsten som inte själva fått sina adress- och kontaktuppgifter utlämnade.

Tillsammans med andra organisationer och forskare anmälde $\mathrm{vi}^{4}$ gränspolisens agerande till Justitieombudsmannen (JO) för att få två centrala frågor prövade. För det första: Vilken skyldighet har socialtjänsten att göra individuella prövningar i enlighet med principen om barnets bästa inför att lämna ut adressuppgifter till polisen? För det andra: Vilken rätt har berörda personer att bli informerade om att socialtjänsten har lämnat ut deras kontakt- och adressuppgifter till polisen? Anmälan var principiellt viktig då lagstödet för utlämnandet inte tidigare använts av polisen och rättsläget, som var oklart, behövde en rejäl genomlysning.

JO valde att inte rikta kritik mot socialtjänsten eller gränspolisen, region Syd, utan framhöll i sitt beslut att den sekretessbrytande bestämmelsen var tydligt utformad och

4 Bakom anmälan stod Hanna Scott (Skåne stadsmission Unga Forum), Anna Lundberg (professor i välfärdsrätt vid Linköpings Universitet), Jacob Lind (doktorand vid Malmö Universitet) och Centrum för sociala rättigheter i Malmö. Se: http://www.jo.se/PageFiles/8604/565-20 I7.pdf 
inte lämnar utrymme för socialtjänsten att göra egna bedömningar av barnets bästa i individuella ärenden. Personlig information som samlats in i syfte att hjälpa utsatta barnfamiljer ska därför, enligt JO, lämnas ut till gränspolisen på begäran. Anmälan till JO klargjorde dock att det inte finns något hinder för socialtjänsten att kontakta de personer vars kontaktuppgifter efterfrågats av gränspolisen för att upplysa dem om att deras information efterfrågats. Som JO kommenterade i sitt beslut är det ytterst upp till domstolen att bedöma myndigheters rätt att ta del av andra myndigheters uppgifter. Någon sådan prövning har dock inte gjorts av domstol.

\section{GRÄNSPOLISEN GENOMFÖR ETTTILLSLAG PÅ SVENSKA KYRKANS LÄGER}

Vårt andra exempel berör den andra dimensionen av brandväggsprincipen om skydd av vissa platser. Sedan lång tid har familjer med erfarenhet av flykt sökt sig till Svenska kyrkan för akut stöd och gemenskap. Studier kring barn och trauma visar att trygghet, tillit och sammanhang är helt avgörande för barns förmåga att hantera trauma (Bath, 2008). Någon långsiktig behandling är svårt att erbjuda för barn som fortsätter leva i rädsla för polisen och deportation, men genom stödjande verksamheter kan föräldrars och barns kapacitet att hantera den otrygga situationen stärkas. Svenska kyrkans arbete med enskilt stöd åt familjer i kontakt med myndigheter, genom samtalsstöd och juridisk rådgivning, har kompletterats med gruppverksamhet som utflykter och läger. Att erbjuda en trygg gemenskap har resulterat $i$ att föräldrar och barn skaffat sig nätverk och vänner, och ökat sin kapacitet att hantera stress, oro och ångest. Arbetet har skett parallellt med det stöd familjerna i vissa fall fått från socialtjänst, barn- och ungdomspsykiatri samt andra vårdgivare.

Som en del i detta arbete anordnade Svenska kyrkan i Malmö ett läger på Klåveröds vandrarhem för sex familjer i augusti 2017. Personalen höll tillsammans med familjerna på att laga middag när civilklädda poliser kom ut ur kringliggande skogspartier och omringade vandrarhemmet. Ett 30-tal poliser, inklusive hundpatruller och gränskontrollanter genomförde en inre gränskontroll på plats och transporterade sedan de fem familjer som saknade papper till Rättscentrum i Malmö. Familjerna verkställdes till sina ursprungsländer.

De deltagande barnen, som alla hade erfarenhet av att leva som papperslösa, påverkades av polisens tillslag på olika sätt beroende på ålder och övriga förutsättningar. För familjerna som deltog, oavsett legal status, var det mycket chockartat, inte minst som de betraktat Svenska kyrkan som en trygg plats. Gränspolisen i region Syd har, både i samband med tillslaget och vid upprepade tillfällen sedan dess, uttalat sig angående att det inte finns några fredade zoner där gränspolisen inte får eftersöka människor med utvisningsbeslut och att det inte finns några hinder mot att gränspolisen hämtar 
barn och unga i exempelvis skolor eller sjukhus (Mikkelsen, 2016). Sådana uttalanden riskerar att förstärka intrycket att polisens befogenheter är obegränsade.

Polisens insatser skall planeras och genomföras i enlighet med grundläggande rättsprinciper, såsom proportionalitetsprincipen och barnets bästa. Polislagen, som är det ramverk som styr gränspolisens arbete, innehåller inte någon tydlig skrivning av barnets bästa och saknar en portalparagraf om barnets bästa motsvarande exempelvis den som återfinns i Utlänningslagen eller Socialtjänstlagen. Polisens egna föreskrifter, bindande regler som polismyndigheten själv utformat, innehåller dock hänvisningar till att myndigheten till exempel vid inre utlänningskontroller och vid planering av och utförande av verkställighet ska ta hänsyn till barnets bästa och att arbetet ska genomföras på ett sätt som tillgodoser grundläggande rättigheter och med särskild hänsyn till exempelvis ålder (se RPSFS, 2011; 2014). Föreskrifterna utgör en form av svag brandvägg som begränsar gränspolisens befogenheter att hämta och kontrollera barn med utvisningsbeslut i eller i anslutning till en skola där hen är elev, samt en kringskärning av motsvarande befogenheter att fysiskt hämta patienter som är inlagda på sjukhus utan behandlande läkares godkännande.

Sammantaget behöver polisens verkställighetsarbete präglas av viktiga avvägningar mellan olika intressen, både samhälleliga och individuella. Även om polisen får i uppdrag av regeringen att verkställa fler avvisningar, behöver polisen väga in hur genomförandet av en utvisning påverkar barn och insatsen behöver dokumenteras och motiveras noggrant utifrån ovan nämnda principer.

Även om kyrkofriden inte längre är reglerad i lag i Sverige finns här, liksom i andra länder, också en tusenårig tradition av fristad i kyrkorna. Det finns starkt internationellt stöd genom exempelvis Europarådet (ECRI, 2016) för att polisen inte heller bör gå in i psykosociala verksamheter eller verksamheter där råd och stöd erbjuds. För att stöd, behandling och rådgivning ska fungera och förtroendet för dessa platser ska kunna bevaras hos utsatta grupper, måste de platser där dessa insatser genomförs vara trygga.

\section{VILKA KONSEKVENSER HAR BRANDVÄGGSPRINCIPEN FÖR MALMÖ?}

Staden är en helt central plats att studera för att förstå hur konsekvenserna av globala processer och konflikter uppstår i praktiken. Det är i staden som växande klyftor och bristen på politisk representation för olika grupper framför allt kommer till uttryck, inte minst $\mathrm{i}$ relation till frågor om gränsöverskridande mobilitet och etnisk diversitet. Men det är också i staden som många av möjligheterna för att bemöta dessa problem kan komma att manifesteras i människors vardag (Righard, Johansson och Salonen, 2015). Närvaron och frånvaron av brandväggar blir som tydligast i verksamheter som 
organiseras på lokal nivå, då det också är där som barn och unga utan papper har störst möjlighet att få sina mänskliga rättigheter tillgodosedda i praktiken. I detta avslutande avsnitt reflekterar vi över grundförutsättningarna för ett tryggt rättighetsarbete i en stad som Malmö med utgångspunkt från den matris ovan (Tabell 1) som beskriver hur brandväggar konstrueras på olika nivåer.

Vi kan utifrån forskning och praktisk erfarenhet se att en viktig del av arbetet med att förverkliga barns rättigheter sker i attityd- och värderingsarbete, inte bara inom institutioner som bedriver rättighetsarbete utan också inom de som utför inre utlänningskontroll. Avgörande här är att individuella tjänstemän och beslutsfattare blir medvetandegjorda om, och ställer sig bakom, att verksamheter som socialtjänst, bibliotek, fritidsverksamheter, ideella organisationer och skola (och så vidare) ska vara trygga platser för papperslösa barn och unga. På samma sätt behövs kunskap om sekretesslagstiftning och på vilket sätt den förmår skydda papperslösa barn och unga när de tar del av grundläggande rättigheter. Tjänstemän kan i många fall använda sitt handlingsutrymme till att stärka brandväggar och bidra till attitydförändringar genom enskilda beslut utifrån mandat och yrkesetik. När olika representanter för staden och lokala organisationer som tillgodoser rättigheter är i kontakt med polisen är det viktigt att påtala nödvändigheten av trygga platser för barn och unga. Det är också viktigt att agera när polisen i media överdriver sina befogenheter genom att påtala de begränsningar som kringgärdar polisens befogenheter, för att värna skyddet av verksamheter som tillgodoser rättigheter.

Att på policynivå införa brandväggar i form av riktlinjer kan vara ett bra och pedagogiskt sätt att ge tjänstemän vägledning i de dilemman de möter i arbetet med papperslösa. Skolverkets (2015) rekommendationer är här en förebild för andra myndigheter och organisationer, dock behöver sådana riktlinjer vara en aktiv och levande del i det lokala arbetet för att brandväggarna ska upprätthållas i praktiken. Brandväggar är under ständig förhandling. Speciellt snabbt föränderliga kan lokala informella policys eller riktlinjer vara då, till exempel, ett nytt beslut från ledningen snabbt kan försvaga hur brandväggar praktiseras. Samtidigt kan informella brandväggspolicys vara väldigt effektiva så länge de efterlevs. Det är inte heller givet att när en informell policy ska omförhandlas och formuleras till formell policy, att den formella policyn innebär ett starkare skydd. Därför kan det i vissa fall vara ett bättre alternativ att i en organisation där det finns ett fungerande informellt brandväggsskydd av något slag, behålla denna informella praktik om det är tydligt att ett formaliserande av dessa brandväggar skulle leda till ett försvagat skydd. Väl formulerade och genomarbetade brandväggar som kommer till uttryck i formell policy och som innebär ett starkare skydd än informella policys är dock att föredra om det är möjligt att uppnå.

Brandväggar genom lagstiftning kan innebära att sekretessbestämmelser stärks för dem som möter papperslösa barn och unga, att känsliga dataregister inte kan användas för att eftersöka någon enbart på grund av migrationsstatus och att explicit förbjuda gränspolisen att göra eftersökningar hos juridiska biträden, ideella organisationer, religiösa samfund, sociala myndigheter, vårdinrättningar och liknande verksamheter. Det är viktigt att komma ihåg att nationell lagstiftning på det här området 
i de flesta fall föranletts av initiativ och riktlinjer som etablerats på lokal nivå. Därför spelar lokalt brandväggsarbete en viktig roll även när det kommer till utvecklingen av lagstiftning.

Det vi särskilt vill lyfta fram är att införandet av brandväggar är en process som innefattar många aktörer på olika nivåer. Såväl kommunala verksamheter eller andra myndigheter som ideella organisationer behöver löpande utveckla sitt förhållningssätt och arbetssätt med papperslösa barn. Att utveckla brandväggar är ett konkret sätt för kommuner, myndigheter och organisationer att genomföra rättighets- och värdegrundsarbete .

Arbetet för brandväggar måste alltid ske i samspel med arbetet för att utöka och försvara den rättighetskatalog som papperslösa ska ha tillgång till. Utan brandväggar riskerar insatser för barns rättigheter att exploateras för utökad gränskontroll (Lind, 2019). De exempel som vi återger ovan där gränspolisen begärde ut adressinformation om papperslösa familjer från socialtjänsten och de gick in på kyrkans familjeläger visar på detta. Både insamlandet av adresser och organiserandet av lägret genomfördes för att kunna säkerställa papperslösa barn deras rättigheter. Detta rättighetsarbete utnyttjades sedan istället för att möjliggöra gränspolisarbete.

Många av de barn och unga som lever i Malmö utan papper lider akut social, psykologisk och materiell nöd, i strid med deras grundläggande mänskliga rättigheter. Brandväggar ger förutsättningar till ett meningsfullt arbete för att så långt det går säkerställa insatser och aktiviteter som främjar barnen och de ungas utveckling. Att skapa och försvara trygga platser i Malmö och i andra delar av landet där barn och unga utan papper kan få tillgång till juridiskt råd, stöd och information är ett exempel på nödvändigt brandväggsarbete. Trygga platser för råd och stöd innebär möjligheter att öka den egna kunskapen om vilka rättigheter och skyldigheter som gäller i en papperslös situation och kan leda till ökade möjligheter till regularisering. Barn och unga utan papper behöver inte bara nya vägar att få laglig rätt att vistas i Sverige, utan också tillgång till information och rådgivning om möjligheter till de regulariseringsprocesser som redan finns. Den nya gymnasielagen är ett exempel på en regulariseringsprocess som många unga i praktiken nekades möjlighet att ta del av på grund av att de fick fel information, inte sällan från myndigheter, eller inte hade tillgång till någon information alls. För de unga som hunnit bli papperslösa när lagen trädde i kraft var det i många fall avgörande att få ta del av information om lagen och sina rättigheter på en trygg plats de vågade besöka. Arbetet för brandväggar är därför nödvändigt, inte enbart för att säkra tillgången till grundläggande rättigheter i praktiken för barn och unga i en papperslös situation, utan också för att på sikt hitta vägar ut ur papperslösheten. 


\section{REFERENSER}

Barnombudsmannen. (2016). Utkast till lagrådsremiss Begränsningar av möjligheten att få uppehållstillstånd i Sverige. Remissvar No. Dnr 3.9:0095/16.

Bath, H. (2008). The Three Pillars of trauma-informed care. Reclaiming Children and Youth, 17(3), 17-21.

Beskow, L (2018). Humanitära konsekvenser av den tillfälliga utlänningslagen. Stockholm: Röda Korset.

Carens, J. H. (2013). The Ethics of Immigration. New York: Oxford University Press.

Crépeau, F., and Hastie, B. (2015). The Case for 'Firewall' Protections for Irregular Migrants: Safeguarding Fundamental Rights. European Journal of Migration and Law, 17(2-3), 157-183. https://doi.org/10.1163/15718166-12342076

ECRI (2016). General Policy Recommendation No. 16 on safeguarding irregularly present migrants from discrimination. Hämtad: http://www.refworld.org/docid/581318d64.html [190909]

EU FRA (2013). Apprehension of migrants in an irregular situation - fundamental rights considerations. Hämtad: https://fra.europa.eu/sites/default/files/ fra-2013-apprehension-migrants-irregular-situation_en.pdf [190909]

Greenbrook, J. (2019). Så ser läkarna på “vård som kan anstå”. Föreläsning under Rosengrenska stiftelsens heldag om Vård som inte kan anstå. Göteborg. 2019-04-07.

Hermansson, L., Lundberg, A., Gruber, S., Jolly, A., Lind, J., Righard, E. and Scott, H. (kommande). Firewall practices - a necessary tool to enable social rights for irregular migrants in social work.

Landelius, A. (2019). Gränspolisen gjorde kontroll på eldfesten. Sveriges Radio. Hämtad: https://sverigesradio.se/sida/artikel.aspx?programid=96\&arti$\mathrm{kel}=7180820$ [190909]

Lind, J. (2019). Governing vulnerabilised migrant childhoods through children's rights. Childhood, 26(3), 337-351. https://doi.org/10.1177/0907568219847269

Lundberg, A., Gruber, S., and Righard, E. (2018). Brandväggar och det sociala arbetets professionsetik. I M. Dahlstedt and P. Lalander (Red.), Manifest: För ett socialt arbete $i$ tiden, 291-302. Lund: Studentlitteratur.

Magnusson, E. (2015). Migrationsverket lovar förbättringar på Malmömässan. Sydsvenskan. Hämtad: https://www.sydsvenskan.se/2015-12-01/migrationsverket-lovar-forbattringar-pa-malmomassan [190909]

Mikkelsen, J. (2016). Gränspolisen tar hjälp av Malmö stad att hitta papperslösa barnfamiljer som ska utvisas. Sydsvenskan. Hämtad: https://www.sydsvenskan. se/2016-11-29/granspolisen-far-hjalp-av-malmo-stad-att-hitta-papperslosa-barnfamiljer-som-ska-utvisas [190909]

Nordling, V. (2017). Destabilising Citizenship Practices? Social work and 
undocumented migrants in Sweden. Lunds Universitet, Lund, Sverige.

Righard, E., Johansson, M., and Salonen, T. (Red.). (2015). Social transformations in Scandinavian cities: Nordic perspectives on urban marginalization and social sustainability. Lund, Sweden: Nordic Academic Press.

RPSFS. (2011). Rikspolisstyrelsens föreskrifter och allmänna råd om Polisens inre utlänningskontroll, RPSFS 2011:4, FAP 273-1.

RPSFS. (2014). Rikspolisstyrelsens föreskrifter och allmänna råd om verkställighet av beslut om avvisning och utvisning, RPSFS 2014:8, FAP 638-1.

Sager, M., Holgersson, H., and Öberg, K. (Red.). (2016). Irreguljär migration i Sverige: Rättigheter, vardagserfarenheter, motstånd och statliga kategoriseringar. Göteborg: Daidalos.

Skolverket. (2015). Elever som är papperslösa - rätt till en likvärdig utbildning. Hämtad: https://www.skolverket.se/publikationer?id=3493 [190909]

SOU 2011:48. (2011). Vård efter behov och på lika villkor: en mänsklig rättighet : betänkande. Stockholm: Fritze.

SOU 2007:34. (2007). Skolgång för barn som skall avvisas eller utvisas. Stockholm: Fritze.

UNCRC. (2003). General Comment No. 5. General measures of implementation of the Convention on the Rights of the Child. Hämtad: https://www.refworld.org/docid/4538834f11.html [190909]

UNCRC och CMW (2017). Joint general comment No. 3 (2017) of the Committee on the Protection of the Rights of All Migrant Workers and Members of Their Families and No. 22 (2017) of the Committee on the Rights of the Child on the general principles regarding the human rights of children in the context of international migration, 16 November 2017. Hämtad: http://www.refworld.org/docid/5a1293a24.html [190909] 
Drömmen om att folk ser bortom sina fördomar och börjar se folk för vad de verkligen är. Människor. Vi är människor och vi ser olika ut. Det finns ingenting i vår etnicitet eller religion som säger att vi är olika värda eller borde behandlas olika. Trots detta behandlas man olika utifrån fördomar. Det måste ske en förändring så att inte rasismen fortsätter att forma våra liv. 


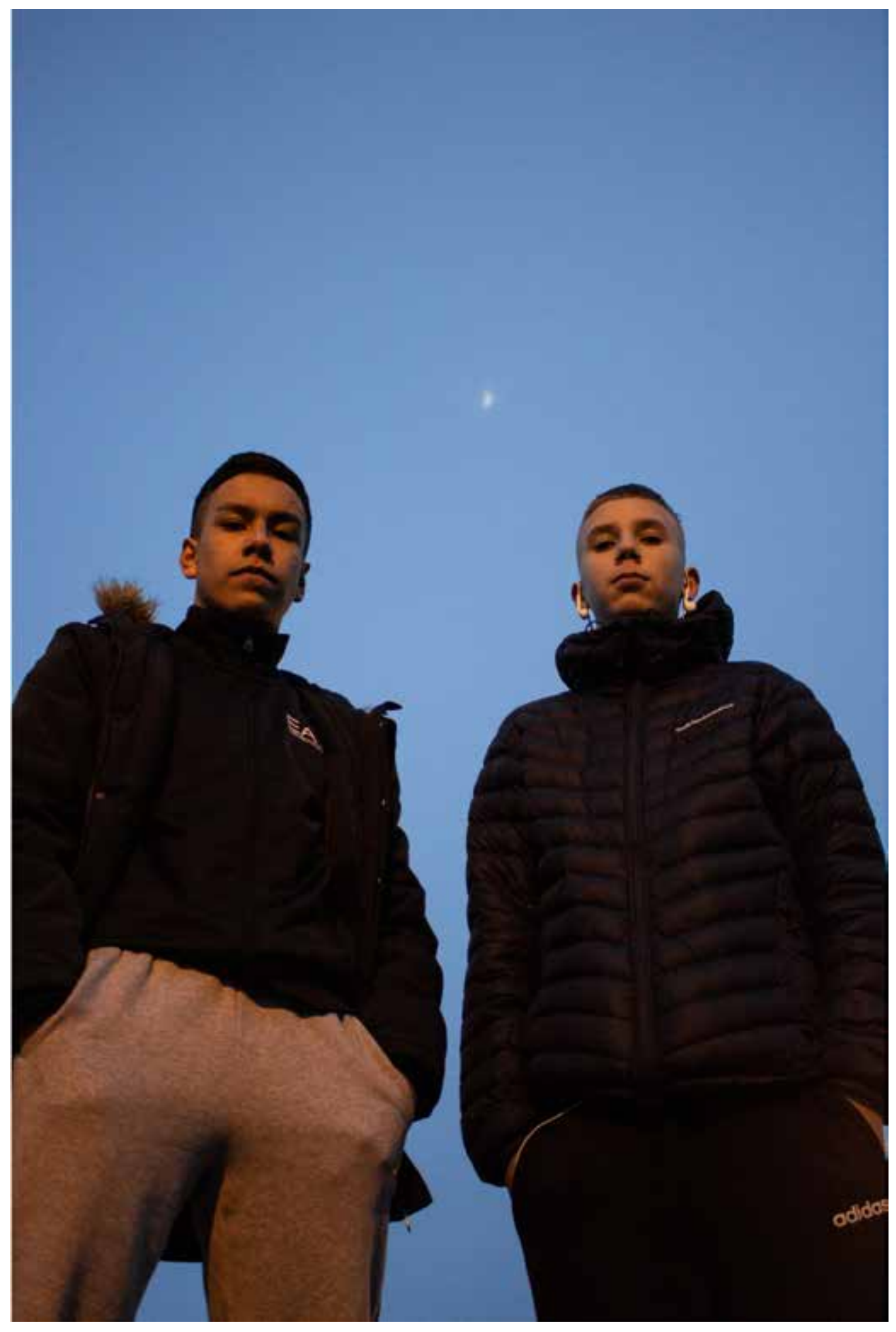

Isabel Appelfeldt Ariza

Fördomar 


\section{Min dröm}

Jag heter Nashiba Majidi och jag kommer från Afghanistan.

Jag vill bli advokat eftersom jag gillar att arbeta med lagar och förordningar. Det är min dröm att skydda tjejer och arbeta mot orättvisor mot tjejer. Det finns många tjejer som inte får bestämma över sitt eget liv, eftersom deras familjer bestämmer över dem. Detta är orättvist! Tjejer har rätt att välja själva.

Jag är också intresserad av och vill studera administration och jobba inom socialtjänsten och domstolar.

Nasiba Majidi 


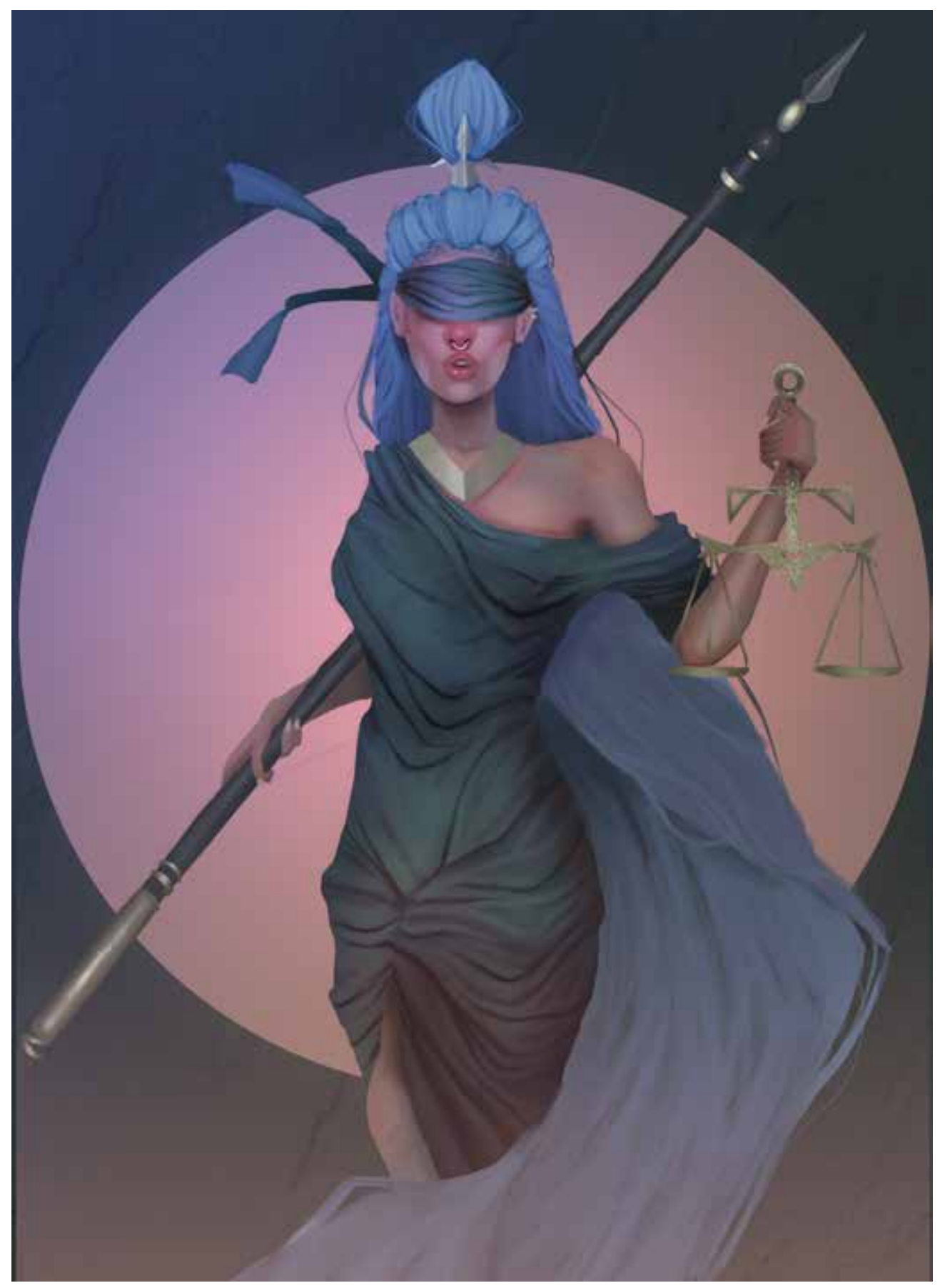

Martin Åkesson

The Reincarnation of Themis 
Malmö ska vara en plats där man ska känna sig trygg dygnet om, kunna gå hem sent på kvällen utan rädslan av att bli överfallen. I min bild försöker jag spegla rädslan och otryggheten man kan känna när man går själv i Malmö stad. 


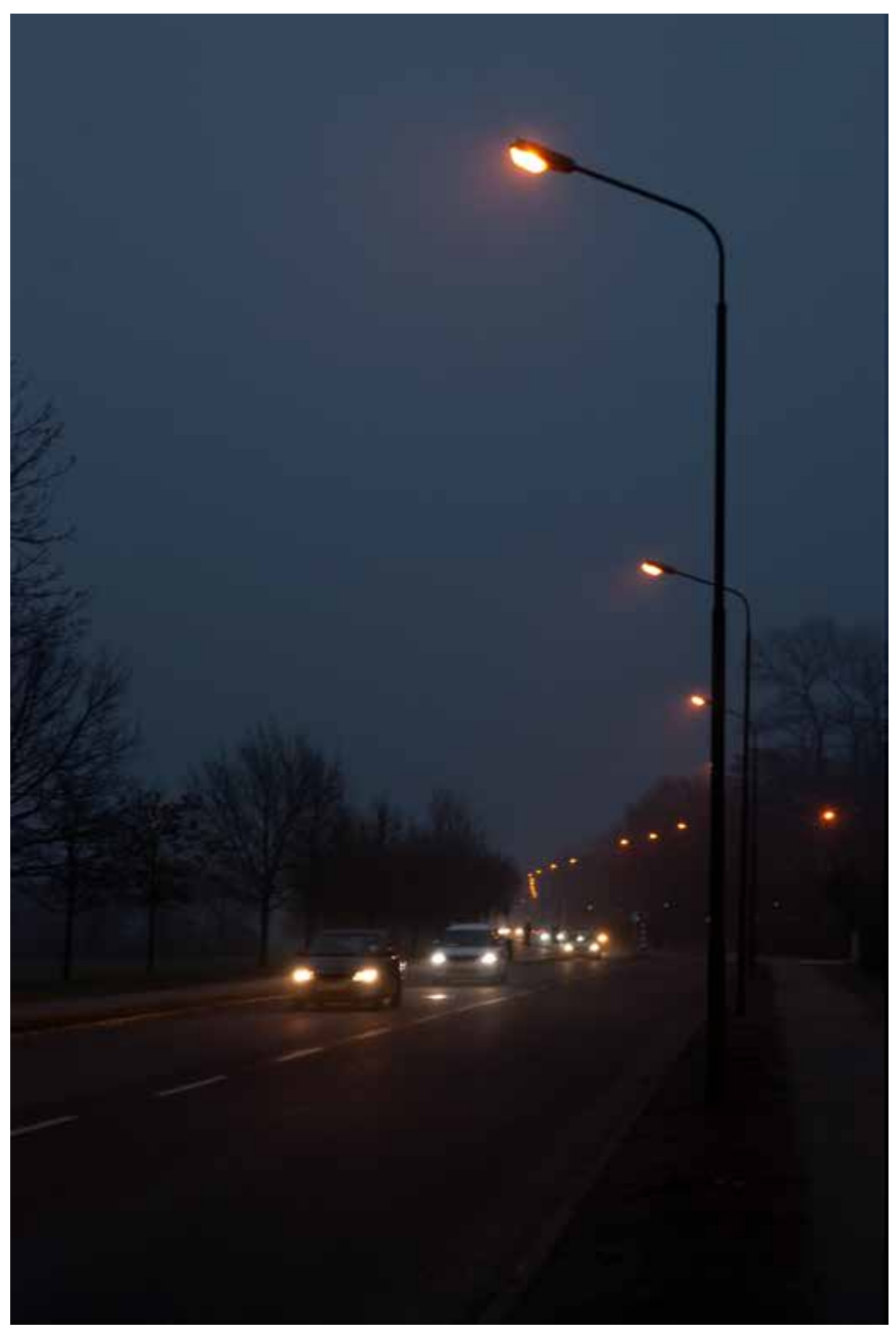




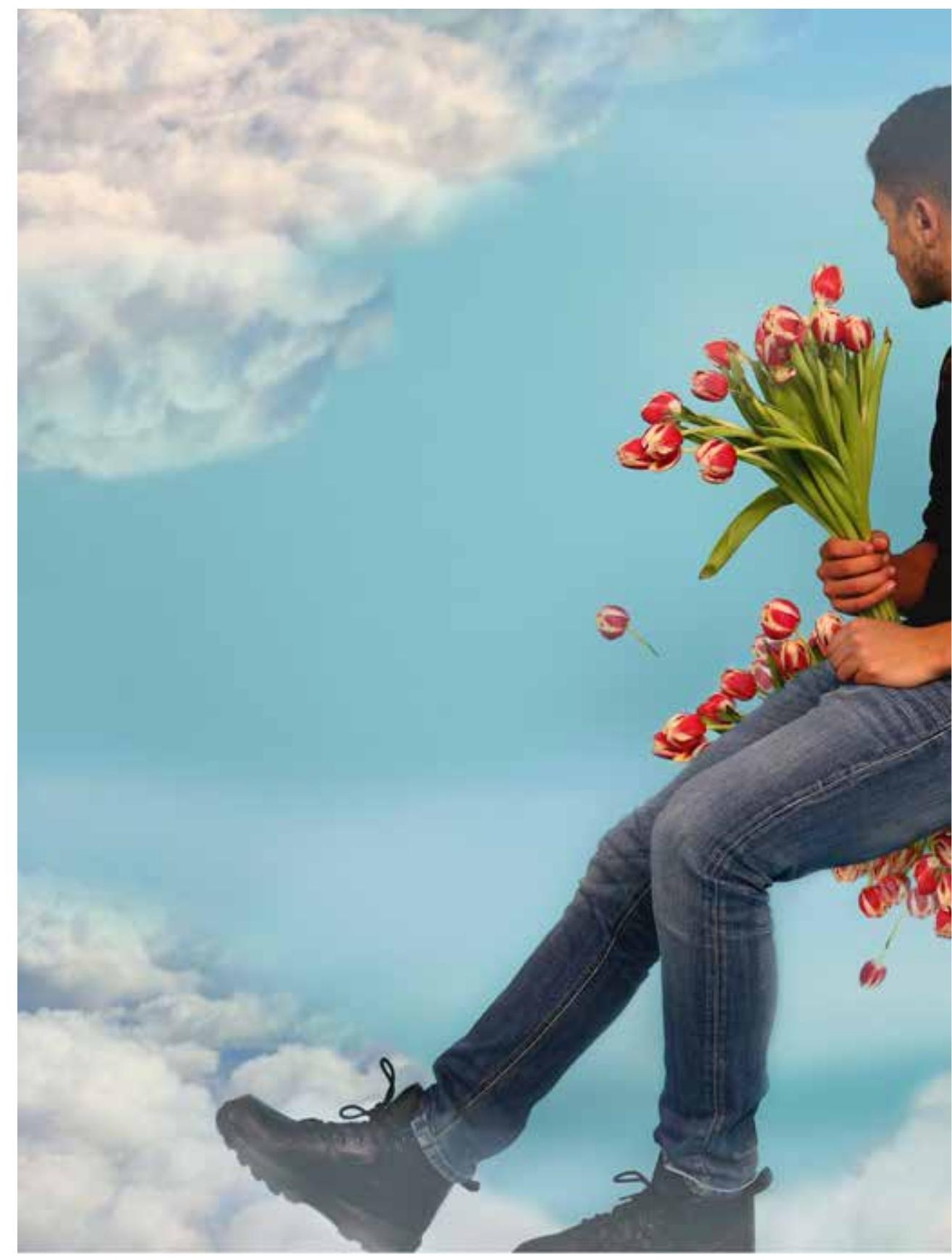

Freedom is a form of belief, if one truly believes they 


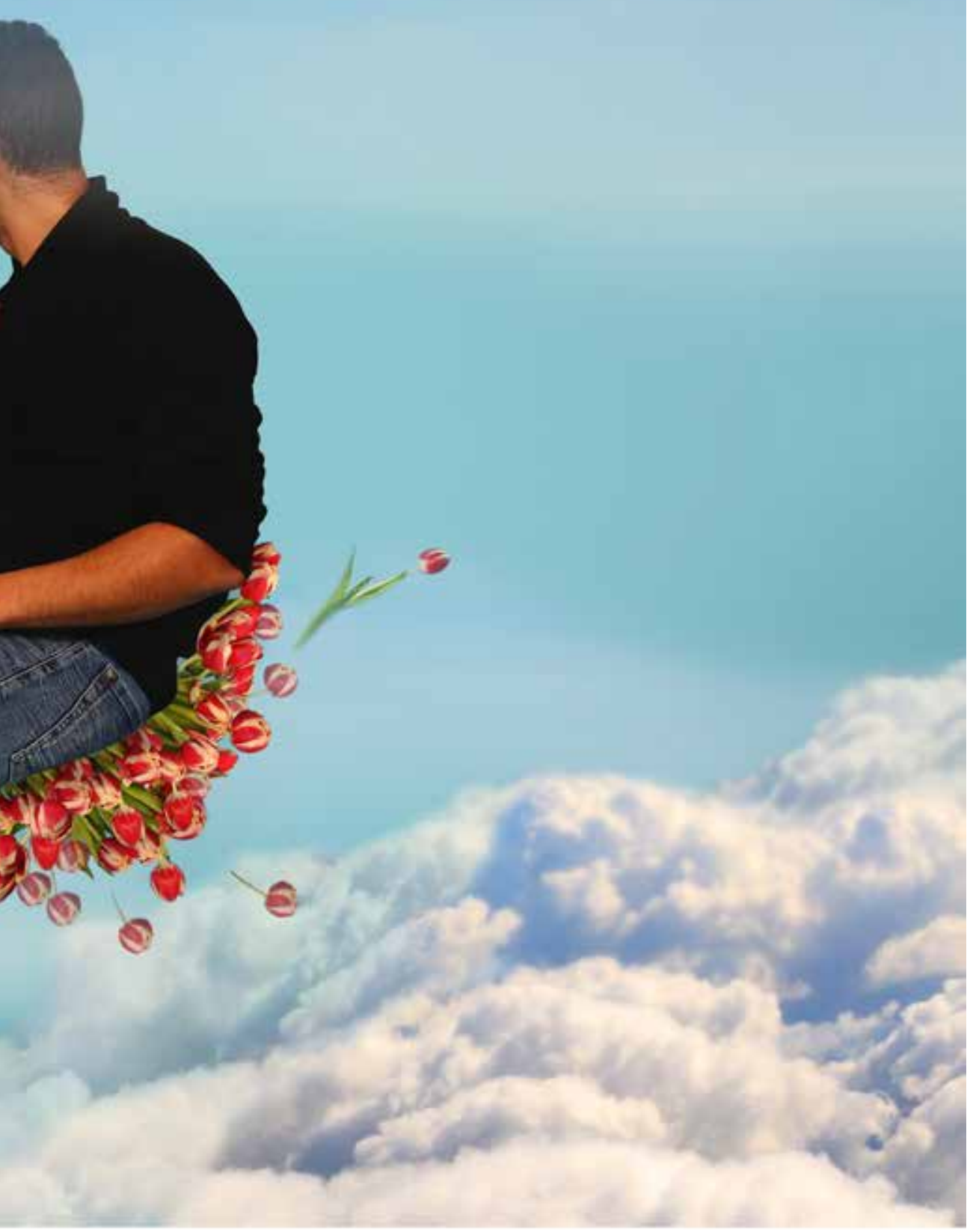

are free it will reflect in their life. That is the dream. 


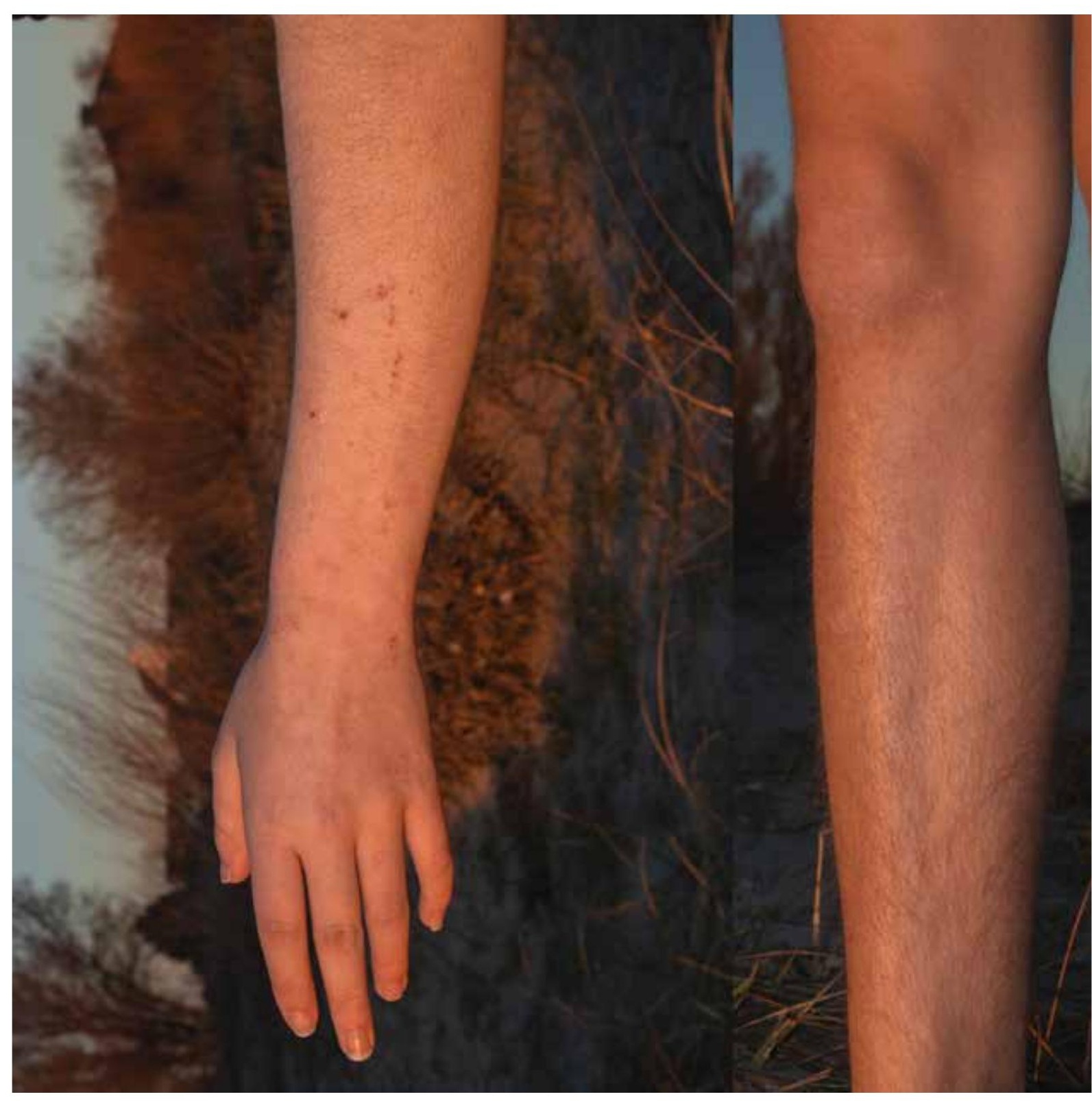

En dröm om att den värld vi lever i ska sluta sätta press kroppsdelar personerna bilden var minst nöjda med. D 
på hur vi ska se ut. Därför valde jag att fotografera de et finns inget rätt, fel eller fult. 


\section{Min dröm}

Jag heter Mohammad och jag har inte någon dröm.

Jag vet inte varför jag har inte någon dröm men jag ska försöka att ha en dröm eftersom livet är ingenting utan ett mål eller en dröm.

Jag tänker på vad jag ska bli eller göra i mitt liv. I framtiden kanske ska jag jag hitta min dröm eftersom jag blir påverkad av min skola, vänner eller något som kommer att hända i framtiden.

Mohammad Akkash 


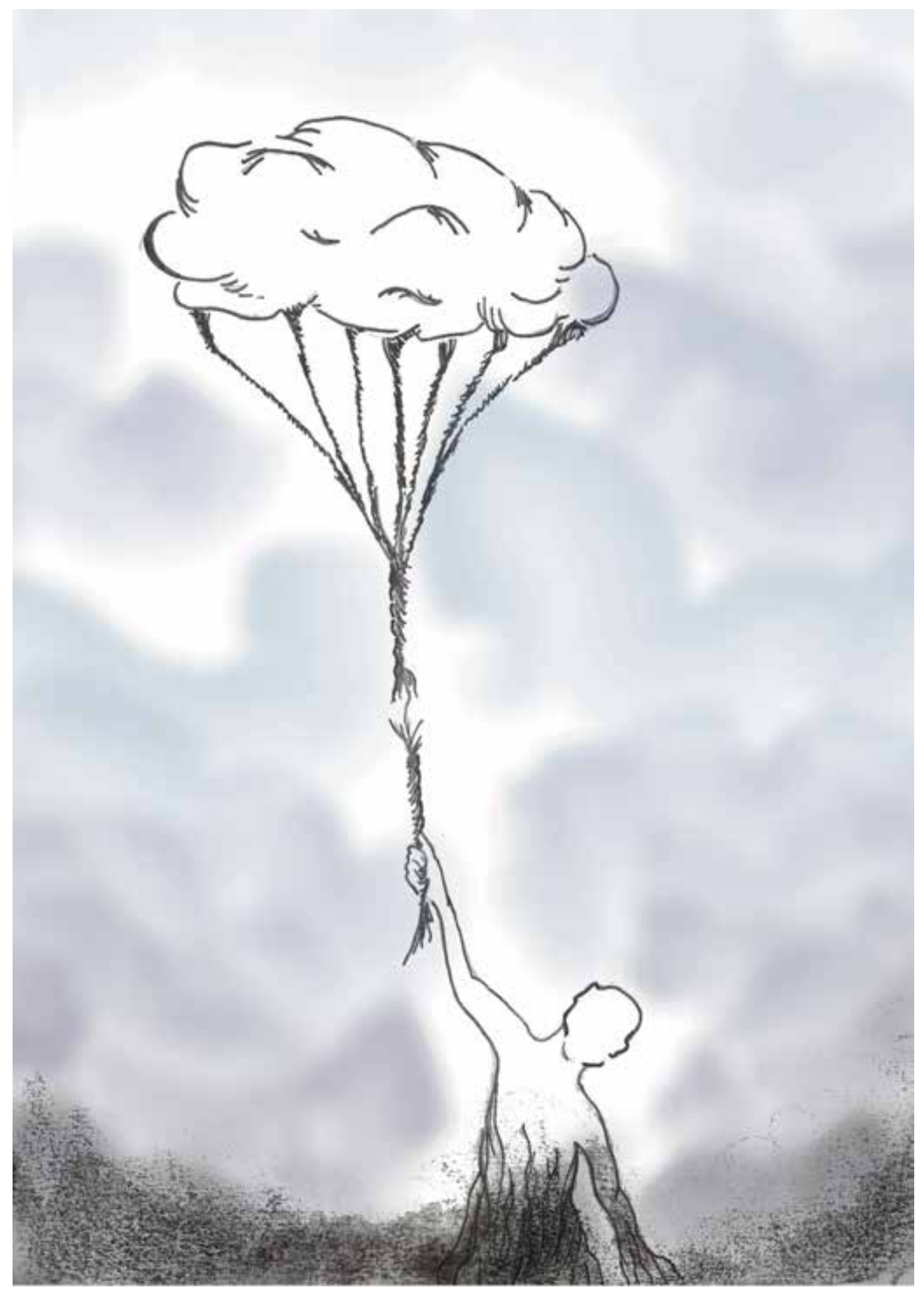

Elise Löf Ingenting utan en dröm 


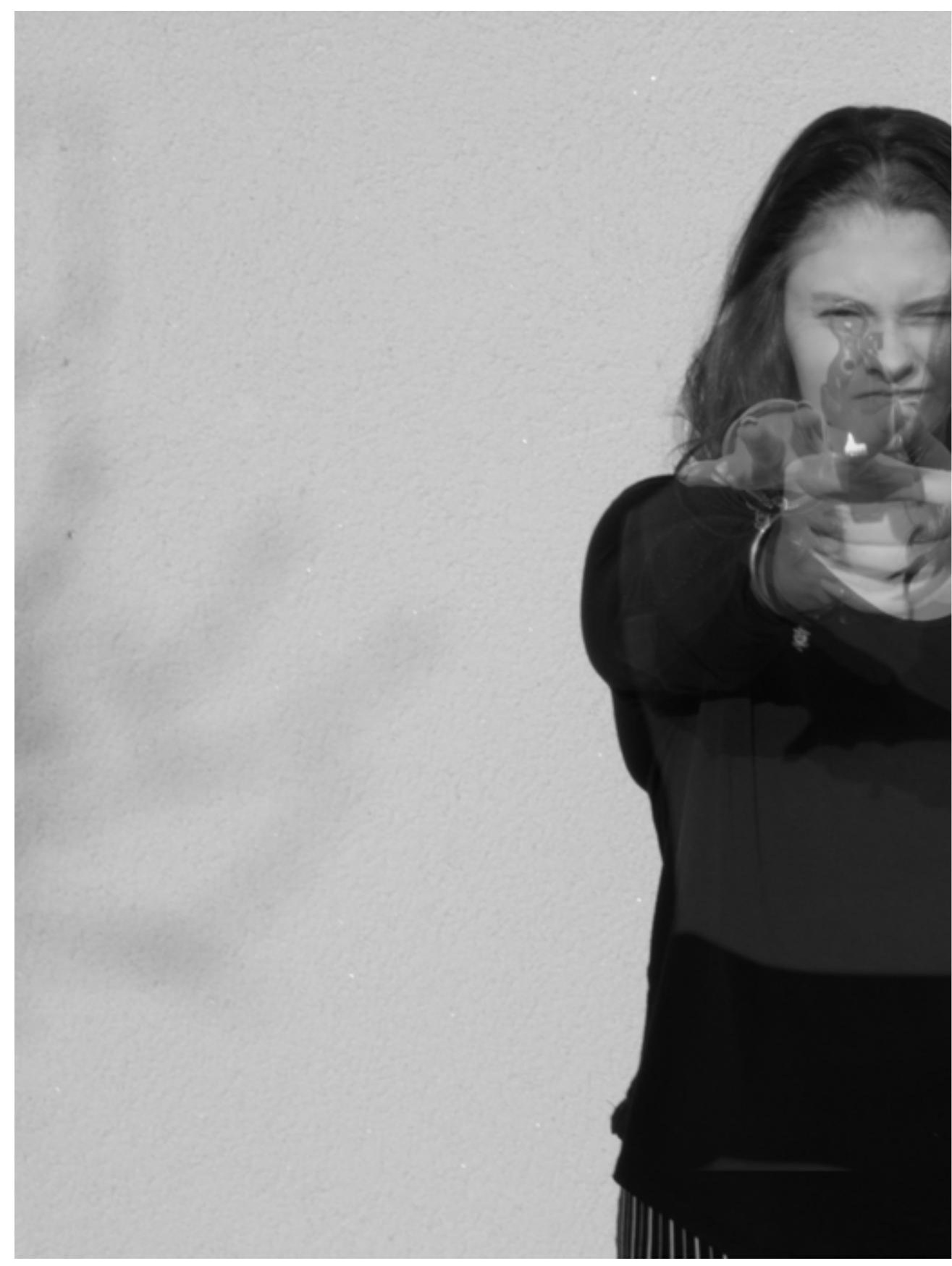

Med min bild vill jag förmedla att skjutningen i Malmö skjutning i resten av världen menar jag att krig ska sluta 


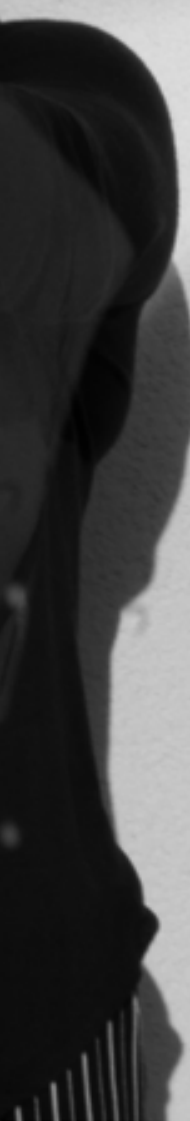

och även i resten av världen ska upphöra. Med och att det ska bli fred på jorden.

Ronja Ramserdal Sluta Skjuta 


\title{
Malmöbarns vardag i hemlöshet
}

\author{
Annelie Björkhagen \& Maria Hjortsjö
}

\section{INLEDNING}

Att ha ett eget hem kan tyckas vara en självklarhet i 2000-talets Malmö. För många barnfamiljer är emellertid verkligheten en annan. Runt två procent av alla barn i Malmö saknar ett stabilt boende (Malmö stad, 2018). Detta kapitel belyser hur hemlöshet kan avspegla sig i drabbade barns vardag i allmänhet och hur erfarenheterna kan skilja sig åt utifrån familjens rättsliga status i Sverige, i synnerhet. Hemlösa barns strategier för att navigera i sin tillvaro är även något som här kommer synliggöras

Avsnittet bygger på resultatet från forskningsprojektet "Hemlösa barn i Malmö". Studien initierades och är i stora delar finansierad av Malmö stad men är ett samverkansprojekt med Malmö universitet. Syftet med studien har varit att undersöka hemlösa barns vardagsliv samt hur deras rättigheter och behov har tillgodosetts i socialtjänstens arbete. Studien består av två delstudier, en foto- och intervjustudie och en aktstudie. Detta antologibidrag bygger på den första delstudien. Materialet består av data inhämtat från 17 hemlösa barnfamiljer genom 19 intervjuer med barn mellan 8 och 16 år. I denna text är ambitionen att ge en bild av barnens vardagsliv såsom barnen upplever den. Barnen har fotograferat sitt vardagsliv under en till två veckor, vilket resulterade i cirka 5000 bilder. Därefter har vi samtalat med dem med utgångspunkt från fotografierna. En kompletterande intervjuguide har säkerställt att hela vardagsbilden har inhämtats. Samtliga informanter är födda utomlands och de flesta av dem har tvingats fly undan krig. Familjernas hemlöshet bottnar i svårigheten att finna en bostad på den öppna bostadsmarknaden. Bostadsbristen i Malmö, i likhet med övriga Sverige, har blivit socialtjänstens ansvarsområde och samtliga familjer är placerade i boenden anordnade av socialtjänsten i Malmö stad.

Kapitlet ger inledningsvis en kort överblick av barns rätt till bostad och hemlöshetens konsekvenser. Därefter redogörs för vad som varit framträdande i samtliga intervjuade barns berättelser följt av en djupare inblick i två hemlösa flickors vardagsupplevelser. Valet av dessa flickor har gjorts för att de står för två ytterligheter. Det finns en stor diskrepans mellan deras livsmöjligheter beroende på föräldrarnas rättsliga status. 


\section{BARN OCH HEMLÖSHET - BAKGRUND}

I regeringsformen 1 kap 2\$ (SFS 1974:152) framgår att offentliga verksamheter särskilt ska trygga rätten till bostad, arbete och utbildning samt verka för god social omsorg, trygghet och för goda förutsättningar för hälsa. Även artikel 27 i barnkonventionen handlar om barn och bostad:

Konventionsstaterna ska i enlighet med nationella förhållanden och inom ramen för sina resurser vidta lämpliga åtgärder för att bistå föräldrar och andra som är ansvariga för barnet att genomföra denna rätt och ska vid behov tillhandahålla materiellt bistånd och stödprogram, särskilt i fråga om mat, kläder och bostad.

Alla barn har samma rättigheter och lika värde samt har rätt till liv och utveckling (Artikel 2 och 6 i barnkonventionen). En brittisk studie visar emellertid att det finns stora skillnader mellan barn och deras möjligheter i livet. Efter sex års ålder är hög socioekonomisk status en mer betydande faktor än tidig kognitiv förmåga (Marmot \& Bell, 2012).

I Sverige lever 186000 barn, eller 9 procent av alla barn i ekonomisk utsatthet. I Malmö är siffran 25 procent. Sedan Rädda Barnen började sina mätningar har Malmö varit den stad där flest barn lever under svåra ekonomiska förhållanden (Rädda Barnen, 2018). Att sakna hem som barn är den yttersta konsekvensen av ett liv i ekonomisk utsatthet. I många av familjerna finns det även sociala problem, antingen som en anledning till hemlösheten eller som en konsekvens av den. Även om många kommuner för statistik inom hemlöshetsområdet finns det fortfarande många kommuner i landet där detta brister. Socialstyrelsen uppskattade i sin kartläggning att det finns 24000 barn i Sverige som har en eller båda sina föräldrar i någon form av hemlöshet (Socialstyrelsen, 2017).

I Malmö är särskilt många barn drabbade. I oktober 2018 var 3306 personer hemlösa: 1959 personer var vuxna och 1347 var barn vilka var hemmahörande i 509 familjer. Anledningen till Malmös stora problem med hemlöshet beror främst på den stora inflyttningen $\mathrm{i}$ kombination med bristande nybyggnation under flera decennier (Malmö stad, 2018). Av de 509 barnhushållen hade enbart 24 av dem, enligt Malmö stads bedömningar, social problematik. Med social problematik menas här att dessa familjer behöver socialt stöd för att klara ett boende som en följd av psykisk ohälsa eller missbruk i familjen eller en kombination av de båda alternativen.

Det är viktigt att komma ihåg att Malmö stad och Socialstyrelsen använder olika definitioner på hemlöshet. I Socialstyrelsens definition av hemlöshet inräknas även de som lever i långsiktiga boendelösningar och de som har eget ordnat boende på kort sikt genom att till exempel vara inneboende hos vänner (Barnombudsmannen, 2016). Malmö stads definition på hemlöshet är:

En person räknas som hemlös om denne saknar egen eller förhyrd bostad, inte bor i något stadigvarande inneboendeförhållande eller andrahandsboende. Om man är hänvisad till tillfälliga boendealternativ eller är uteliggare. Det centrala är att boendefrågan endast är löst på mycket kort sikt eller inte alls. 
Såväl nationell som internationell forskning visar på olika konsekvenser för barn som lever i hemlöshet. Hur mycket barn påverkas beror på barnens ålder, hemlöshetsperiodens längd, det sociala nätverket som omger barnet samt vilken kvalitet som det tillfälliga boendet har (Andersson \& Swärd, 2007; Christensen \& Hildingson Boqvist 2009; Mayock, Corr, \& O'Sullivan, 2011). Det är emellertid viktigt att vara medveten om svårigheterna att se vilka faktorer som direkt kan kopplas till hemlöshetssituationen eftersom barn som är hemlösa även är exponerade för andra riskfaktorer som till exempel fattigdom, migration, missbruk och våld. Hemlöshet är ofta den allra yttersta konsekvensen av dessa olika riskfaktorer. Cutts et al., (2011) har sett att det finns ett samband mellan en osäker boendesituation, trångboddhet, dålig hälsa, lägre vikt och risk för utvecklingsproblem bland små barn. Shinn \& Weitzman (1996) menar att hemlösa barn generellt har ett sämre hälsotillstånd än andra barn. De drabbas oftare av fysisk och psykisk ohälsa och utvecklar dessutom ofta olika beteendeproblem. Andra studier har visat konsekvenser som brist på privatliv och lekmöjligheter eftersom det kan vara svårt eller inte tillåtet att ta hem kamrater (se exempelvis Alstam, 2012; Gove et. al., 1979). Skolsituationen påverkas också negativt eftersom hemlöshetssituationen ofta innebär många skolbyten och brist på en plats att studera (Anthony, Vincent, \& Shin, 2018; Baptista, Benjaminsen, Busch-Geertserma \& Pleace, 2018; Buckner, 2008). I en amerikansk studie har man kommit fram till att fattigdom, social isolering och våld är sammankopplat med hemlöshet (Anooshian, 2005). En av de få studier där hemlösa barn har kommit till tals har visat att barnen känner skam, besvikelse, ilska och rotlöshet. Många barn lider också av att det saknas pengar i familjen (Walsh, 1992). I Barnombudsmannens rapport berättar barnen om att det ofta är stökigt och trångt när barnen lever i akuta boendelösningar (BO, 2016). År 2010 tillsatte kommunstyrelsen i Malmö Kommissionen för ett socialt och hållbart Malmö (se Isacssons bidrag i denna antologi). I slutrapporten slogs det fast att staden behöver arbeta med att minska hemlöshet, trångboddhet, dåliga bostadsförhållanden och dålig yttre miljö för barn och unga. Även här konstateras att undermåneliga boendeförhållanden påverkar berörda barns hälsa. Det fanns en tydlig medvetenhet och strävan om att förbättra tillvaron för hemlösa barn i Malmö (Stigendal \& Östergren, 2013). Nedan följer en nutidsbild över hur tillvaron kan te sig för hemlösa barn i Malmö. Empirin är hämtad från studien Hemlösa barn i Malmö

\section{MALMÖBARNS VARDAGSLIV SOM HEMLÖSA - EN ÖVERSIKT}

De barnfamiljer som ingått i studien har varit placerade på de boenden som Malmö stad lyckats uppbringa. Flera av dessa boenden har varit relativt små och enkla. Familjerna har, beroende på familjens storlek, ofta haft ett till två rum med tillgång till 
eget badrum. Några familjer har haft tillgång till eget kök medan andra familjer har fătt dela kök och tvättstuga. Vissa familjer har varit placerade i något större lägenheter med tillgång till både eget kök och badrum. Barnens kännedom om varför de bor $\mathrm{i}$ ett tillfälligt boende varierar men några barn förstår att familjen behöver hjälp från socialtjänsten för att de just saknar bostad.

Flera av barnen upplever att deras boende är litet, trångt och att det saknas avskildhet. Ett eget rum står ofta högt upp på önskelistan. För barnen symboliseras trångboddheten av ett överskott av ljud och rörelse vilket påverkar deras koncentrationsmöjligheter. Utöver detta uppges att det kan vara svårt, och ibland otillåtet, att ta hem kamrater till boendet. Ju äldre barn (tonåringar) desto svårare att bo på en begränsad yta. Några tonåringar fann att deras psykiska hälsa påverkades negativt av trångboddheten. En utmaning för såväl äldre barn som deras föräldrar var att de tvingades bo i samma rum, vilket omöjliggjorde en personlig sfär och integritet. Att leva tätt inpå påverkar familjeinteraktionen då det är svårt att "fly undan" om det skulle behövas.

Ovissheten om varaktigheten i det tillfälliga boendet var en återkommande stressfaktor. När biståndet skulle omprövas fanns det en stark oro över att familjen skulle "hamna på gatan". Varaktigheten i det tillfälliga boendet var allt mellan tre månader till två år. Den familj som hade bott längst i sitt boende var en relativt stor familj med sex barn i åldrarna tre till tretton år. Även om de flesta barnen inte oroade sig över detta, efterlystes stabilitet så att familjen fick trygghet och trivsel i tillvaron.

Vardagen för studiens barn innebär mestadels att vara i skolan. Skolan anses generellt fungera bra och många av barnen trivs där. Skolsituationen kan dock vara problematisk och för åtminstone ett barn var den egna otillåtna skolfrånvaron kopplad till rådande boendesituation. När skolan har slutat för dagen är några barn kvar på fritids, har hemspråk eller nyttjar skolans läxhjälp medan andra barn tar sig hem för att äta och göra sina läxor där. Många av barnen leker gärna med kamrater både i och utanför skolan.

Det finns en variation bland barnens aktiviteter. Vissa barn har inga aktiviteter överhuvudtaget andra barn utövar skilda sporter i mer eller mindre organiserad form såsom ex. fotboll, tennis och simning. Många av dessa var gratisaktiviteter som erbjuds av såväl föreningar som Malmö stad. Några barn uppger att de på sin lediga tid är hemma och tittar på tv eller på film i sina datorer, spelar på playstation eller leker med syskon eller kamrater. Datorerna är ofta sådana som barnen har fått via skolan. I några familjer delar flera syskon på dessa. Att läsa böcker är något som uppskattas av en del av barnen och de berättade att de gärna deltog i de bokläsartävlingar som biblioteken anordnar varje sommar. Vad barnen läser, på vilket språk och hur mycket de läser varierar. Biblioteket, både stadsbibliotekets filialer runt om i Malmö och det egna skolbiblioteket, besöks gärna av barnen då det förutom böcker även finns tillgång till internet. Biblioteken ger inte sällan barnen möjlighet att vara tillsammans med vänner en stund efter skolan. En del barn berättar om att de deltar i aktiviteter som anordnas av biblioteket.

Att "ta sig runt" i Malmö görs promenerandes, med cykel eller buss. Alternativt kan barnen bli skjutsade av föräldrar som har eller kan låna en bil av släktingar eller 
bekanta. När barnen är runt i Malmö vistas några av dem gärna i det område där de bor eller besöker de någon av stadens parker, temalekplatser eller inrättningar såsom ridhus, simhallar eller köpcentrum.

De flesta av barnen är inte så insatta i familjens ekonomi, även om vardags- och fritidsaktiviteter till viss del blir beskurna utifrån rådande situation. Att leva med begränsad ekonomi får ovillkorligen konsekvenser för vad barnen kan göra efter skolan inte minst om en aktivitet kostar eller ej. Att inte ha råd med sådant som andra kompisar har tillgång till som till exempel Skånetrafikens Jojokort, mobiltelefon eller kläder påverkar också tillvaron. Känslan att leva med begränsad ekonomi uttrycks av ett barn som pinsamt och genant. En familj kompenserar dock tillvaron i det tillfälliga boendet med omfattande leksaksinköp till barnen. Det finns även barn i studien som får veckopeng upp till $200 \mathrm{kr}$ i veckan.

\section{TVÅTONÅRSFLICKORS PERSPEKTIV}

\section{Erza}

Erza, är 15 år och bor tillsammans med sin mamma och sina två syskon som är 11 och 13 år. Familjen har flyttat runt i Europa men har ett permanent uppehållstillstånd i Grekland. Familjen kom för två år sedan till Sverige som EU-migranter. Mamman fick en hyreslägenhet i Malmö och ett så kallat svartjobb inom pendlingsavstånd. Efter några månader förlorade mamman arbetet varmed familjen blev utkastade från lägenheten de hyrde. Familjen tvingades söka hjälp hos socialtjänsten för att få tak över huvudet. Först erbjöds de ett boende i närheten av Hässleholm men eftersom barnen hade påbörjat sin skolgång i Malmö blev det svårt för dem att bo kvar. Erza hoppas på att familjen kan få uppehållsrätt i Sverige och därmed personnummer så de kan leva på samma villkor som alla andra. Hon menar att familjen nu behandlas annorlunda än andra Malmöbor som har försörjningsstöd.

Vi skulle då kunna ha en lägenhet som passar, socialen skulle hjälpa oss. Nu hjälper socialen oss halvt, när det gäller pengar och sådana saker, alltså inte hundra procent. Det är därför vi har det så. Om socialen hjälpte oss till hundra procent, så skulle vi ha det bättre.

Erza berättar att familjen får reducerat försörjningsstöd vilket ytterligare försvårar familjens situation och ökar barnens känsla av utanförskap. Enligt socialtjänstens riktlinjer är det enbart den vuxne i familjen som får detta avdrag för att förhindra att barnen ska drabbas. Detta exempel visar att det är något som endast fungerar i teorin. Barnen drabbas mycket hårt när föräldrarna får reducerad norm. Idag uppstår det mycket 
konflikter mellan Erza och hennes mamma med anledning av familjens begränsade ekonomi. Mestadels handlar dessa konflikter om att Ezra hela tiden måste gå till sin mamma och förhandla om pengar. Det hon önskar allra mest är ett busskort. Hade hon bara haft ett busskort så hade hon kunnat vara med kompisar och sommarjobba:

Ja, jag behöver busskort, min mamma kan inte köpa det för hon har inte så mycket pengar, hon kan helt enkelt inte. Men jag behöver ett busskort och hon behöver jobba för att få ett papper om uppehållstillstånd i Sverige. Hon har inte det så det är svårt för oss.

Ibland får Ezra pengar av mamma till en bussbiljett men då måste hon åka hem inom relativt kort tid för att slippa köpa en ny. Det innebär att hon ofta får avstå från att följa med sina vänner när de ska åka på en längre tur exempelvis till Västra hamnen. Hennes vänner bor i villor och lägenheter och Erza menar att de flesta har mycket pengar att röra sig med. Hon skäms över att hennes familj är fattig. Hon menar att hennes kompisar åker och shoppar efter skolan men då får hon gå hem.

Ja skulle också vilja ha smink, kläder och skor, sånt som tjejer vill ha. Jag vill ha en Iphone, men det går inte. Vi är fattiga...

Familjen bor nu i ett vandrarhemliknande genomgångsboende som är beläget i centrala Malmö. Malmö stad hyr boendet av en privat hyresvärd. Vissa delar är nyligen renoverade, bland annat ett uppehållsrum och tvättstugan. Familjen har en lägenhet bestående av ett rum, kök och badrum. I rummet finns en våningssäng med tunna smutsiga bäddmadrasser och en resårsäng där mamma sover. Den används även som soffa på dagen. De yngsta barnen sover i våningssängen och Erza sover i köket på en madrass på golvet för att få integritet. Hon tycker att boendet fungerar dåligt utifrån många olika aspekter:

Hemma det finns insekter också och det är jättejobbigt för de är äckliga. Många gånger kan jag inte sova på natten. Och jag är 15 år, jag måste ha ett eget rum.

Alla i familjen har tagit upp problemet med ohyra i form av kackerlackor och annan ohyra i lägenheten. Insekterna är framförallt aktiva på natten så mamman är uppe sent för att döda och plocka bort dem. Ohyran tar sig in överallt - även till maten i kylskåpet. Tallrikar och glas förvaras i ugnen för att försöka skydda dem från att exponeras för ohyran. Hyresvärden har lovat en större sanering. Mamman har själv lagt ner mycket pengar på bekämpningsmedel men inget hjälper. Erza skäms när vänner kommer på besök och ser bostaden. Hon vill självklart bo med sin familj, men hon menar att om situation inte blir bättre så skulle hon få ett bättre liv på ett HVB-hem, i likhet med de som kommer hit som ensamkommande flyktingbarn.

Jag önskar ett boende, det är inget speciellt, bara att jag ska bo själv, att det ska vara lugnt i mitt rum, att jag ska kunna studera och att jag ska ha de sakerna jag behöver.

Erza går i en skola som ligger gångavstånd från boendet. Hon äter sällan frukost, en kopp kaffe är ofta allt. Följande citat illustrerar hur Ezras skoldag kan se ut: 
Jag fixar mig och går till skolan, går till lektion, tråkigt, spelar på mobil och sen lunch. Vi äter, vi skolkar en halvtimme och sen kommer vi tillbaka och läraren frågar var vi har varit, vi säger att vi har varit med kurator (skratt), men de vet att vi ljuger.

Ezra äter för det mesta lunch i skolan men det händer att hon även hoppar över den. Efter skolan går hon gärna till biblioteket. Tyvärr så kan hon inte låna böcker eftersom hon saknar personnummer men hon lyssnar gärna på musik, spelar eller läser någonting. Biblioteket tillhandahåller även läxhjälp och svenskundervisning. Ibland stannar Ezra kvar på skolan eftersom hon där har tillgång till internet. Hon berättar att hon går i åttonde klass och att hon har mycket prov. Hon vill klara skolan på ett bra sätt:

Jag ska bli något viktigt. Det är jättejobbigt för mig, jag vill inte att jag ska bli trött på min framtid. Jag vill bli något som... en advokat, läkare eller någonting, eller någon rektor i någon skola.

När Ezra kommer hem på eftermiddagen äter hon ofta mellanmål, ibland en toast och dricker mjölk. På kvällen äter familjen middag som mamma har lagat. Favoriträtten är spagetti och kyckling. I familjen äter de ofta mycket grönsaker. Hon gillar att laga mat, vilket hon har lärt sig av sin mamma. Hon berättar om hur de brukar fira högtider:

Alltså vi dansar och dricker, vi skojar och skrattar mycket och sånt. Det var en vecka sedan min bror och jag fyllde år. Vi hade fullt med musik, vi hade öppet och vi festade.

Erza har under sin uppväxt dansat. Hon är duktig och har fått en särskild utmärkelse. Hon deltar idag i en dansgrupp på Tegelhuset Bricks i Rosengård som vänder sig till unga mellan 12 och 18 år. Verksamheten är gratis och barnen behöver inte ett personnummer för att kunna vara med. Ibland åker hon till Triangeln eller till Emporia efter skolan. I övrigt träffar hon mest sina vänner på fritiden. Då uppehåller de sig gärna på gräsmattan utanför boendet.

Vi brukar spela, känna solen och naturen, vi promenerar lite, vi tränar volleyboll och sånt.

Ezra berättar också att hon tidigare umgåtts med vänner som inte har varit så bra för henne. Hon har varit föremål för en barnavårdsutredning eftersom hon har umgåtts med tjejer som har prostituerat sig. Hon menar att hon mår fysiskt och psykiskt dåligt. Hon har periodvis ont i tänderna men inte lika mycket som sin syster. Hon tycker att hennes tänder är sneda och fula. Erza berättar att hon för det mesta sover dåligt. Hon sover två till tre timmar sedan vaknar hon. Det har varit på samma sätt sedan hon kom till Sverige. Hon tror det beror på stress och oro, men även på de ständiga konflikterna med sin mamma:

Det finns många gånger som jag bråkar med mamma och jag blir arg och då kan jag inte gå till mitt rum för att bli lugn. Jag måste ha henne där så vi bråkar mer och sånt. Det är svårt att få vara ifred. 
Familjens osäkra situation i Sverige är något som ofta oroar Ezra. Hon har pratat med sin mamma om oron och eventuell påtvingad återflytt till sitt hemland. Hon inser dock att det inte är lönt då mamma är maktlös:

Hon kan inte göra någonting, det är inte hennes fel, det är inte så att hon kan fixa det, hon kan inte.

Tidigare forskning har visat att optimism och en positiv framtidstro är en skyddande faktor och är alltså en motvikt mot stress och svårigheter (Rutter, 1985; Walsh, 1998; Werner \& Smith, 1992). Av den anledningen fick barnen frågan om hur de tror att deras liv kommer att se ut om några år. Erza berättar:

Det som jag önskar är att vi ska ha en egen lägenhet som passar oss, alltså jag är femton år nu, ska det hela tiden vara så i mitt liv? Ska jag vara i en lägenhet som är så liten, där jag inte har mitt rum som jag kan sitta i och studera och sådana saker. De två är små [hennes syskon, förf. anm.] jag är stor, inte som dem. Och min mamma, vad ska hon göra? Ska hon hela tiden sova i en soffa och på natten kommer insekterna och promenerar på henne? Om jag hade barn ... jag vill inte att de ska bo som mig.

\section{Kommentarer}

Erza använder begreppet "fattig" när hon ska beskriva sin familjs ekonomiska situation. Erzas berättelse om sitt vardagsliv skapar en förståelse för vad begreppet barnfattigdom ${ }^{1}$ verkligen innebär för de barn som drabbas. Den ger en bild av hur fattigdomen på olika sätt nästlar sig in i alla delarna av deras vardagsliv och påverkar dem såväl praktiskt som emotionellt; såsom skammen över att bo på golvet i ett kök fullt med ohyra och sakna möjligheten att köpa sådant som de flesta andra barn kan.

Erzas psykiska och psykiska hälsa har troligtvis påverkats negativt på grund av hennes livssituation som helhet. Hon pendlar mycket mellan hopp och uppgivenhet. Hon vill göra något bra med sitt liv och kan, till skillnad mot sina småsyskon, se familjens livssituation i ett större perspektiv. Erza känner en stor otrygghet med anledning av att familjen inte vet om de får vara kvar samt upplever skam och socialt utanförskap på grund av familjens svåra ekonomiska situation. Konflikterna med mamman och ifrågasättandet av det liv som familjen lever är en ytterligare belastning. EU-migranter har ett svagare rättsligt skydd än asylsökande och papperslösa barn. Erzas tankar och drömmar om framtiden ger en bra sammanfattning av intervjun. Hon har önskningar, förhoppningar men känner också en stark förtvivlan över livssituationen som medför hinder för henne att förverkliga sina drömmar.

I Begreppet "barnfattigdom" har kritiserats kraftigt i media eftersom det anses att barn i Sverige inte kan jämföras med de som traditionellt benämns som fattiga, exempelvis svältande barn i tredje världen. Denna debatt ledde till att barnrättsorganisationen BRIS övergav begreppet och istället började använda begreppet social och ekonomisk utsatthet (SVT Nyheter, 20।3). 
Anya bor tillsammans med sin mamma, pappa och fem syskon i åldrarna 5 till 12 år i ett övergångsboende, som består av en liten villa i de östra delarna av Malmö. Anya är äldst med sina 13 år. Familjen kommer från Syrien. De flyttade mellan många olika lägenheter under krigsåren för att söka trygghet. Vid ett tillfälle var det 40 personer i en lägenhet och alla fick sova på golvet. När familjens yngsta barn var 40 dagar gammalt flydde familjen från hemlandet. Anyas pappa åkte i förväg till Sverige och ordnade med alla nödvändiga papper, därefter anslöt resten av familjen. Hela familjen har bott samlad i Sverige i två år. I Sverige bor några släktingar, bland annat pappans bror, resten av den utvidgade familjen är utspridd över olika delar av Europa.

Familjen har permanent uppehållstillstånd i Sverige och familjen erhåller etableringsbidrag för sin försörjning. Båda föräldrarna studerar. Familjen bor i ett så kallat övergångsboende och kommer därför inte kunna bo kvar i längden utan måste aktivt leta efter en ny bostad. I huset finns fyra rum. Anya delar rum med en av sina systrar. När de ska göra sina läxor brukar ytterligare en syster komma till deras rum eftersom det är den lugnaste platsen i huset. De har svårt att hitta en bostad eftersom de är många i familjen. Enligt bostadsnormen bör familjen ha fyra till fem rum och kök. Anya är medveten om att de bor i ett tillfälligt boende men ingen från socialtjänsten har pratat med henne om familjens boendesituation. Hon vill gärna att familjen hittar ett nytt hus i samma område där de bor för att det skulle innebära att de kan gå kvar i skolan där hon trivs. Hon tycker att det var svårt första tiden i Sverige:

Först tyckte jag att det var jättetråkigt när vi kom till Sverige för jag kunde inte svenska. Men nu tycker jag att det är bra för jag fick nya vänner.

Anya går i åttonde klass. Skolan är belägen några minuters promenad hemifrån. På eftermiddagen går hon på hemspråk eller på läxhjälp. Därefter går hon och den nästan jämnåriga systern hem, resten av syskonskaran är kvar på förskola eller på fritidshem. De tre äldsta barnen får alla hjälpa till och förbereda maten och även att städa upp efteråt. På kvällen studerar hon, tittar på tv eller spelar Playstation. Klockan 22 är det läggdags. När det är sommarlov har Anya emellertid andra vanor. Då brukar hon ta sovmorgon. Efter frukost brukar hon städa rummet och sedan går hon ut och leker.

Anya gillar att studera och läser mycket skolböcker. Anya och hennes systrar tycker även om att läsa skönlitterära böcker, främst på arabiska men även på svenska och engelska. Hon har bland annat läst Anne på Grönkulla. De läser även i den heliga boken Koranen. Anya och hennes syskon går ofta till biblioteket. Hon läser ungefär fem böcker i veckan. Det är rör sig om så kallade lättlästa böcker. På sommaren, varje tisdag, spelar hon och hennes systrar tennis. Det som hon gillar allra mest är att cykla:

Jag har lärt mig cykla när jag kom till Sverige så det är nytt för mig.

Familjen har fyra cyklar. Anya och hennes systrar brukar cykla till Rosengårds centrum, Triangeln eller till Möllevångstorget. Mamma har precis köpt en lådcykel för att kunna transportera de yngre barnen. Anya och hennes ena syster går också och tränar simning. De behöver bli simkunniga för att få godkänt betyg i idrott. På sommaren 
köper familjen Skånetrafikens sommarkort och de passar på att resa till olika städer som till exempel Simrishamn, Helsingborg och Halmstad. På sommaren grillar de även i trädgården. Anya gillar mest mammas mat men ibland går de även på restaurang och äter arabisk eller turkisk mat. De äter mycket frukt, grönsaker, ris, yoghurt och bröd. När de ska fira något bjuder de hem andra familjer och då brukar de även köpa tårta. När de äter sitter de ofta tillsammans på golvet i vardagsrummet.

Ett av de fotografier som Anya visar är taget när hon är på Folktandvården för undersökning. Hon berättar att hon har fina tänder och att hon borstar dem varje morgon och kväll. Hon har aldrig haft ont i tänderna. Familjens osäkra boendesituation är något som Anya berör när det gäller tankarna om framtiden:

Jag tror att vi kommer flytta nästa år men jag vet inte vart. I Malmö, fast jag vet inte vilken gata eller så.

\section{Kommentarer}

Anya och hennes familj har under flera år levt ett vardagsliv i Syrien under brinnande krig men har till slut tvingats att fly till Sverige för att få större chans att överleva. Trots att de endast har bott två år i Sverige lever de ett vardagsliv som lika gärna hade kunnat vara kännetecknande för vilken familj som helst: hämta och lämna på förskola, studier, läsa böcker, spela tennis, Skånetrafikens sommarkort, matlagning, disk och träffa vänner. Det visar att när människor fär grundläggande förutsättningar i form av bostad och försörjning skapas en trygghet som blir betydelsefull när familjen möter de utmaningar det innebär att skapa ett nytt liv i ett annat land.

\section{HUR KANVI FÖRSTÅ HEMLÖSA BARNS VARDAG?}

Vår foto- och intervjustudie handlar om barnfamiljers ofrivilliga hemlöshet efter ankomst till Sverige och hur barnen i familjerna navigerar i denna tillvaro. Studien handlar också om att lyfta upp hur barnens behov och rättigheter beaktas i socialtjänstens arbete.

Tydligt i vår studie är att de barnfamiljer som vi har mött står inför en mängd utmaningar. Innan krig och flykt, har flertalet av dem haft en relativt stabil tillvaro i det forna hemlandet och för vilka såväl arbete, försörjning som bostad har varit självklara delar av vardagen. För familjerna handlar det idag om möjligheten att kunna komma till rätta i Sverige, lära sig språket, hitta en fungerande tillvaro och få en tillfredsställande försörjning. De flesta av familjerna kämpar för att kunna hantera sin vardag. Boendet är en viktig förutsättning i denna process och utgör ett nav i familjernas tillvaro. Boendet och bostadsområdet skapar vissa meningsbärande erfarenheter 
för den enskilde. Inte minst avseende identifikation och vad vi tro oss vara eller kunna bli (Alstam, 2013). Flertalet av barnfamiljerna i studien bor i trånga, enkla boenden och i allmänhet utsatta bostadsområden. Att ha ett undermåligt boende och inte veta lösningen på framtida boendesituationen påverkar oavkortat den som drabbas av det.

Vi har i underlaget kunnat se en tydlig koppling mellan framförallt äldre barns psykiska mående, aktuell boendesituationen och påverkan på deras identitetsskapande i detta. Även om alltför generella slutsatser inte kan dras av forskningsunderlaget visar resultaten att just tonåringarna i allmänhet mår sämre eftersom de har större behov av integritet och att de har lättare att betrakta sig själva i ett större perspektiv. Detta stöds även av tidigare forskning (Andersson \& Swärd, 2007; Mayock, Corr, \& O'Sullivan, 2011). Meningsfulla fritidsaktiviteter är en skyddande faktor (Rutter, 1985; Werner \& Smith, 1982) och hjälper många av barnen att hantera en svår tillvaro. För barn som utöver hemlöshet lever i familjer med knapp ekonomi (se ex. Walsh, 1992) är det av stor vikt att barnen kan ta del av kostnadsfria aktiviteter som såväl staden som ideella organisationer kan erbjuda dem. Stadens bibliotek förekom på många av barnens fotografier och är ett exempel på en plats som har varit viktig för dem. Där kan de "surfa", läsa böcker eller umgås med kompisar.

Trygghet skapas inte sällan genom en förutsägbar tillvaro (Christensen \& Hildingson Boqvist, 2009). Boendetillvaron för informanterna är idag relativt oförutsägbar och i underlaget efterlystes en tydlighet i själva boendeprocessen. Fram till maj 2019 har Malmö stad bistått strukturellt hemlösa med bostad men i och med nya riktlinjer ${ }^{2}$ kommer stödet till dessa att begränsas. Detta innebär att livssituationen för strukturellt hemlösa barn och deras familjer i Malmö kan bli än mer pressad.

I vårt material har vi även funnit att utfallet av hemlösheten tenderar att skilja sig åt utifrån de förutsättningar som givits familjen. Särskilt tydligt är detta i den hemlösa flickan Ezras fall. Alla barn som befinner sig i Sverige ska i enligt med artikel 2 i barnkonventionen behandlas på sammas sätt oberoende av föräldrarnas status - det vill säga oavsett om de är flyktingar, asylsökande, papperslösa eller EU-migranter. Detta infrias inte för Ezra och hennes syskon. Deras familj är extremt utsatt eftersom försörjningsstödet reduceras när mamman inte kan försörja sin familj vilket är ett krav för EU-migranter. I sådana fall är det viktigt att en barnkonsekvensanalys genomförs för att undersöka hur barnen drabbas av beslutet. Även om samtliga familjer i studien lever med stora utmaningar har Ezra och hennes familj hamnat $i$ en negativ spiral i den rådande boende- och livssituationen som är ännu mer alarmerande. Barnen har hamnat i ett socialt utanförskap som riskerar att påverka barnen såväl på lång som kort sikt.

2 De riktlinjer som Malmö stad antog i maj 2019 innebär att personer med speciella svårigheter (missbruk eller svår psykisk sjukdom) ska få hjälp med sin boendeproblematik. Detta innebär att strukturellt hemlösa endast får akuthjälp. Prövning av biståndet kommer att ske veckovis. (Sveriges Radio 2019). 
Sammanfattningsvis kan konstateras att när det gäller barnens situation har studien visat att barnen och deras rättigheter och behov i stort sett är osedda. I de fall socialtjänsten har förhållit sig till artikel 3 i barnkonventionen, barnets bästa så är det mer utifrån ansatsen att barnet är en del i en hemlös familj - inte som en egen unik individ. Ingen av barnen uppger att socialsekreterare har frågat dem om deras upplevelse av situationen vilket kan tyckas anmärkningsvärt - inte minst relaterat till artikel 12 där alla barn har rätt att uttrycka sin mening och få den respekterad. Samtal med barn och barnkonsekvensanalyser före och under en boendeplacering borde vara ett givet arbetsverktyg i det sociala arbetet med hemlösa barnfamiljer.

I materialet framgår tydligt att barnen har mer eller mindre omedvetna strategier för att hantera sin vardag. Barnen uppvisar på olika sätt, tydliga former av agens, det vill säga de "manövrerar" utifrån det givna sociala sammanhang där de befinner sig, det vill säga är så kallade kompetenta aktörer (Alstam, 2013). Men vad innebär barns förmåga att göra egna val och uttrycka sin vilja- när det inte finns någon mottagare som backar upp eller lyssnar på dem? Det är viktigt att kunna uppmärksamma barn och ungdomar och deras mångfald och som professionell hjälpare ständigt reflektera över detta i det egna förhållningssättet.

Relaterat till studien är det tydligt att vissa av barnen skulle behöva mer stöd i att få en bättre tillvaro. Alla barn som stadigvarande befinner sig i Malmö behöver bemötas på ett jämbördigt sätt; vårt antologibidrag visar att så inte är fallet.

\section{REFERENSER}

Andersson, G. \& Swärd, H. (2007). Barn utan hem: Olika perspektiv. Lund: Studentlitteratur.

Alstam, K. (2013). Trångboddhetens vardag i Bak, M., och von Brömssen, K. (red.). Barndom och Migration. Umeå: Boréa Bokförlag

Anooshian, L. J. (2005). Violence and aggression in the lives of homeless children: A review. Aggression and Violent Behavior, 10(2), 129-152.

Anthony, E. R., Vincent, A., \& Shin, Y. (2018). Parenting and child experiences in shelter: A qualitative study exploring the effect of homelessness on the parentchild relationship. Child \& Family Social Work, 23(1), 8-15.

Baptista, I., Benjaminsen, L., Busch-Geertserma, V., \& Pleace, N. (2018). Family homelessness in Europe. Bryssel: European Observatoryon Homelessness.

Barnombudsmannen (BO) (2016). Inget rum för trygghet - barn och unga om vräkning och hemlöshet, max 18-2016. Stockholm: Barnombudsmannen.

Buckner, J. C. (2008). Understanding the impact of homelessness on children: Challenges and future research directions. American Behavioral Scientist, 51(6), 721-736. 
Cutts, D. B., Meyers, A. F., Black, M. M., Casey, P. H., Chilton, M., Cook, J. T., Coleman, S. (2011). US housing insecurity and the health of very young children. American Journal of Public Health, 101(8), 1508-1514.

Christensen, R. \& Hildingson Boqvist, A. K. (2009). Att leva i en utsatt situation med barnet i fokus. Lund: Studentlitteratur

Gove, W R., Hughes, M., Galle, O R. (1979). Overcrowding in the home: An empirical Investigation of Its Possible Pathological Consequences. American Sociological Review, 44(1), s. 59-80.

Malmö stad (2018). Malmö stads kartläggning av hemlösheten 2018. Malmö: Malmö stad.

Marmot, M. \& Bell, R. (2012). Fair society, healthy lives. Public Health, 126, 10.

Mayock, P., Corr, M. L., \& O'Sullivan, E. (2011). Homeless young people, families and change: Family support as a facilitator to exiting homelessness. Child \& Family Social Work, 16, 391-401.

SFS (1974:152). Regeringsformen. Stockholm: Justitiedepartementet.

SFS (2002:453). Socialtjänstlagen. Stockholm: Socialdepartementet.

Rädda Barnen (2018). Barnfattigdom i Sverige-årsrapport 2018. Stockholm: Rädda Barnen.

Rutter, M. (1985). Resilience in the face of adversity: Protective factors and resistance to psychiatric disorder. British Journal of Psychiatry, 147, 598-611.

Shinn, M., \& Weitzman, B. (1996). Homeless families are different. Homelessness in America: A reference book. National Coalition for the Homeless and Oryx Press.

Socialstyrelsen (2017). Hemlöshet 2017-omfattning och karaktär. Stockholm: Socialstyrelsen.

Stigendal, M \& Östergren P-O (2013) Malmös väg mot en hållbar framtid. Hälsa, välfärd och rättvisa. Malmö: Kommission för ett socialt hållbart Malmo囚.

Sveriges Radio (2019) Skärpta rutiner för hemlösa i Malmö och Göteborg: Hämtat den 12 september 2019 från: https://sverigesradio.se/sida/artikel. aspx?programid $=83 \&$ artikel $=7256802$

Walsh, F. (1998). Strengthening family resilience. New York: Guilford Press.

Walsh, M. E. (1992). Moving to nowhere: Children's stories of homelessness. New York: Auburn House Westport, CT.

Werner, E. E., \& Smith, R. (1982). Vulnerable but invincible: A longitudinal study of resilient children and youth. New York: McGraw. Hill.

Werner, E. E., \& Smith, R. S. (1992). Overcoming the odds: High-risk children from birth to adulthood. Ithaca and London: Cornell University Press. 


\title{
Unga i Malmö om staden, bostadsområdet och talet om
}

\author{
Anne Harju, Erica Ingemansson \& Jakob Tornberg
}

Utgångspunkten för detta kapitel är unga människors upplevelser och erfarenheter av Malmö. Som Christensen och O 'Brien (2003) påpekar är det viktigt att inkludera barn och unga i diskussioner av städer och därmed öka förståelsen för hur de erfar och konstruerar dem. En inkludering av deras röster utgör, förutom ett här och nu perspektiv, även en grund för deras framtida engagemang i förändringar av staden. I kapitlet fokuseras överlappningen mellan mediabilden, bostadsområdet och staden i sin helhet. Detta för att erfarenheter och uppfattningar av ett av dessa områden även påverkar och påverkas av de andra, till exempel kan medias rapportering av vissa platser påverka hur barn och unga ser på och använder platser (Christensen och O'Brien 2003; Harju 2017). Villkoren för unga i frågor som rör möjligheter till utveckling och välbefinnande påverkar också uppfattningar och erfarenheter av staden och dess platser (Chawla och Malone 2003). Till detta kan kopplas frågan om hur den socioekonomiska polariseringen i en stad påverkar barn och unga. Frågan är relaterad till rapporter och forskning om segregerade städer, där skillnader i faktorer som ekonomi, boende, hälsa och skolresultat har avgörande inverkan på de boendes vardagsliv, sociala relationer och känslan av delaktighet (Stigendal 1999; Salonen 2011; Bunar och Sernhede 2013; Kommissionen för ett socialt hållbart Malmö 2013; Johansson et al. 2015; Blomdahl et. al. 2017). Utifrån denna utgångspunkt finns det olika uppfattningar, önskemål och konflikter om platser i staden, både mellan unga och vuxna men också mellan unga. Det är likheter och skillnader mellan unga vad gäller synen på sin stad, sitt bostadsområde och medierapportering som är i fokus för detta kapitel. Bakgrunden till detta fokus är Malmös unga befolkning, 48 procent är under 35 år och nästan en femtedel är under 18 år (Malmö stad 2017). Med tanke på att dessa unga är framtidens "city-makers" så är de viktiga aktörer i det som den brittiske kulturgeografen Doreen Massey (2005) kallar throwntoghetherness. Begreppet syftar på att relationer, platser och rum i städer alltid är föremål för kontinuerliga och konstanta interaktiviteter om betydelse, innebörd och intern rangordning. Städer och dess platser är således utifrån detta perspektiv alltid föremål för förhandlingar om dess varande och blivande. 
Resultatet i detta kapitel kommer från ett projekt som genomförts i ett samarbete mellan barnrättsorganisationen "Reach for Change" och Malmö universitet. Materialet som kapitlet bygger på samlades in under två faser hösten 2015 och våren 2016, och består av grupp- och enskilda intervjuer samt en enkätstudie.

\section{KORT OM STUDIEN}

Intervjuer

I den första fasen genomfördes sex intervjuer med totalt elva unga 12-17 år. Tre av intervjuerna genomfördes enskilt och tre i grupp. Målet var att få ta del av ungas berättelser från olika delar av staden. De medverkande bor därför i olika delar av Malmö, dock är huvuddelen boende i områden med låg medianinkomst. Kontakten togs genom vuxna som arbetar med ungdomsverksamheter såsom fritidsgårdar och föreningsliv i de aktuella områdena. Förutom att få del av de intervjuades erfarenheter och tankar, var syftet att få ett underlag till en enkät utformat utifrån ungas perspektiv (se nedan). Intervjuerna var semi-strukturerade, vilket innebär att det fanns en intervjuguide med teman och frågor, men deltagarna kunde fritt svara och utveckla sig runt ämnen som kom upp. De intervjuade ombads att beskriva sin vardag och lokala erfarenheter utifrån frågor som: hur skulle du beskriva området där du bor, berätta om en situation där du tyckt att det är bra att bo i Malmö, vilken är din bild av människorna i Malmö, beskriv den bild som media ger av Malmö.

\section{Enkäten}

Enkätstudien omfattar 464 elever i årskurs 7-9 från fem skolor i Malmö. Syftet med enkäten var att, utifrån resultatet från intervjuerna, utvidga det geografiska området och på så sätt få ett bredare underlag i förhållande till ungas syn på och erfarenheter av sin stad. Skolorna finns i tre delområden (Kirseberg, Bunkeflostrand och Husie enligt den gamla stadsdelsindelningen) och de är valda för att det är områden som skiljer sig åt vad gäller placering i staden, medelinkomst och typ av boendeformer. Själva genomförandet gick till på två sätt, antingen besöktes klassen av projektledaren som informerade eleverna om enkätens syfte och upplägg, eller så informerades klassläraren både muntligt och skriftligt och sedan informerade denne eleverna och delade ut enkäten. Vad gäller enkätfrågorna, ville vi ställa dem på ett sätt som skulle göra det lätt för eleverna att förstå och svara på frågorna, och därför baserades de i hög grad på de teman samt uttryck och ordval som kommit fram i intervjustudien. Hela enkäten är indelad i sex delar och i detta kapitel har vi valt att analysera de delar som handlar om syn på och erfarenheter av staden, det egna bostadsområdet och mediabilden. 
Vad gäller urval finns en jämn fördelning utifrån kön och årskurs. I förhållande till bostadsområde fick de medverkande själva ange vilket område de bor i. Det visade sig att de är utspridda i fler av Malmös områden, med dominans av elever boende i $\mathrm{Hu}-$ sie. Svaren från boende i Husie kontrollerades mot boende i övriga bostadsområden och inga tydliga skillnader hittades. För att få en uppfattning om fördelningen utifrån områden kopplat till "låg" respektive "hög" socio-ekonomisk bakgrund, skapades tre kategorier utifrån medianinkomst i de områden de deltagande angett att de bor i. Som framgår i tabell 1 finns det en jämn fördelning mellan svarande från "låg" respektive "hög" medan "övriga" står för huvuddelen av de medverkande i enkätstudien.

Tabell 1. Boende utifrån medianinkomst i bostadsområde

\begin{tabular}{ccc}
\hline & Antal & Procent \\
\hline Hög-Limhamn/Bunkeflo & 69 & $16 \%$ \\
Låg-Rosengård Fosie & 71 & $16 \%$ \\
Övriga & 302 & $68 \%$ \\
\hline
\end{tabular}

Vi har varit särskilt intresserade av att undersöka om det finns skillnader i resultatet utifrån kön, boendeområde och etnicitet ${ }^{1}$. Bivarata analyser genomfördes därför i förhållande till dessa kategorier. Vad gäller etnicitet var det inte möjligt att göra tillförlitliga analyser på grund av ett lågt antal svarande i speciellt kategorin födda inom Europa, och därför är fokus i resultatdelen på kön och boendeområde.

\section{RESULTAT}

\section{Mediabilden}

I både intervjuerna och i enkäten ställs frågor om mediabilden av Malmö. Det som framkommer är att medverkande anser att mediabilden är överdrivet negativ. I intervjuerna svarar samtliga när de ombeds att beskriva den bild som media ger av Malmö, att bilden är onyanserad och att den i huvudsak fokuserar det negativa. Flera menar att media inte bryr sig om att rapportera om positiva händelser och aktiviteter som pågår i staden, utan att de mest fokuserar på problemen som våldsamma händelser, som till exempel skottlossning och granater:

Johan: Katastrof [om mediabilden av Malmö]

Jakob: Personligen har jag aldrig upplevt något dåligt i Malmö, kanske ibland så. Men inte så att jag går på gatan och någon vill döda mig. Det är nästan det media får Malmö att låta som, det låter nästan som Baghdad eller något sådant. $\mathrm{Nu}$ när

I Här menas kategorierna född "Utanför Europa", "Inom Europa" och "Norden/Sverige" 
alla bomber, allting, alltså det låter som värsta skitstaden.

(Intervju med Johan och Jakob)

I citatet framkommer - genom referens till rapportering om granater, skottlossning, bomber - en uppfattning av att Malmö i media framställs som en farlig stad. Samtidigt framgår att Johan och Jakob själva inte upplever Malmö som en så farlig, vilket också framkommer i andra intervjuer:

Stora medier skriver ju mest om att det är skjutningar och sådant här. Och det kanske inte är riktigt sant eftersom jag inte har upplevt någonting. Mest negativa grejer som händer här uppmärksammas mest.

(Intervju med Karin)

Vad jag har sett så skrivs inte så mycket bra och roligt om Malmö. Men det finns ju massa kul som man kan göra här, det finns ju alltid något att hitta på i Malmö. Och alltid någonstans att gå.

(Intervju med Angelica)

Ur intervjuerna framträder en bild av att de medverkande tycker att mediabilden är orättvis. De förnekar inte att det finns problem men anser samtidigt att dessa får för stor uppmärksamhet i förhållande till allt positivt som finns i staden.

Utifrån hur unga i intervjuerna upplever mediabilden av Malmö, bad vi svarande i enkäten ta ställning till påståendet "Tidningar, TV och sociala medier visar ofta upp en negativ bild av Malmö". I tabell 2 framgår att om man tar fasta på svaren "håller med mycket", "helt" och "lite grann" visar resultatet, precis som intervjuerna, att svarande upplever att mediabilden av Malmö är problemfokuserad.

Tabell 2. Påstående: Tidningar, TV och sociala medier visar ofta upp en negativ bild av Malmö

\begin{tabular}{ccc}
\hline & Antal & Procent \\
\hline Håller inte alls med & 67 & $15 \%$ \\
Håller med lite grann & 205 & $46 \%$ \\
Håller med mycket & 100 & $23 \%$ \\
Håller helt med & 70 & $16 \%$ \\
\hline
\end{tabular}

Det finns inga skillnader utifrån kön och var man bor i förhållande till påståendet om den negativa mediabilden av Malmö. Däremot finns skillnader vad gäller frågan om man tycker att den negativa mediabilden är rättvis eller orättvis jämfört med egna erfarenheter. Här svarar killar i högre utsträckning än tjejer att de tycker att den är orättvis eller mycket orättvis. Det finns också en skillnad utifrån var man bor. Svarande från Rosengård/Fosie anger i högre utsträckning än de från Limhamn/Bunkeflo och övriga att mediabilden av Malmö är orättvis eller mycket orättvis jämfört med egna erfarenheter. Svarande från Rosengård/Fosie anger också i högre utsträckning att den 
negativa mediabilden påverkar dem negativt. Även andra studier visar att boende i områden liknande Rosengård och Fosie känner sig utpekade och stigmatiserade av media (Ericsson m.fl. 2002; Ristilammi 2006; Hallin m.fl. 2010; Stigendal 2011, 2016a; se också Egnell och Ivert samt Sixtensson i denna antologi).

\section{SYN PÅ OCH ERFARENHETER AV STADEN}

I både intervjuer och enkätresultat framträder en bild av Malmö som utifrån de ungas perspektiv är både och, d.v.s. de kan se både för- och nackdelar med staden. Denna tudelade bild framkommer till exempel i en intervju med tre killar som på frågan om vilken bild de har av människorna i Malmö svarar:

Adel: Alla är helt olika faktiskt om man pratar om Malmö. Alla har olika bakgrund. Max: Ja, alla har olika bakgrund. Men det är ju inte världens bästa stad Malmö om man tänker på allting som händer. Så det är ju inte bara bra om man säger så.

Adel: Men det finns också bra.

Max: Ja, det finns det.

(Intervju med Max, Kalle och Adel)

I citatet kommer det positiva i form av mångfald och det negativa i form av att "det händer saker" fram. Att det händer saker kopplas i samtliga intervjuer till sådant som man har hört talas om. Det är tydligt att de medverkande i förståelse av sin stad måste förhålla sig till både berättelsen om den, såväl som egna erfarenheter. De rör sig således mellan det Christensen (2003) kallar "emplaced" kunskap om staden, dvs. sin egen lokala kunskap som byggts upp genom ett konkret engagemang och en "spatial" kunskap, dvs. en formaliserad, abstrakt och allmän kunskap. Denna rörelse mellan "emplaced" och "spatial" kunskap kommer bland annat upp i intervjun med Silvana, Nathalie och Amina:

Amina: Ja alltså jag är stolt över Malmö. Ja folk tror. Jag såg en video på Facebook för några dagar sedan om att nu på sista tiden är det kaos i Malmö. Alltså, det är så. Man blir lite skeptisk att folk lägger ut videos på att det är problem här i Malmö. Folk lägger ut bomber och sådana grejer. Men om man tänker, så är Malmö ett fint ställe där alla tänker på varandra. Ja, det är ett fint ställe, jag är stolt över att jag är född i Malmö. Men andra folk ser det som ett dåligt ställe och kallar det för ghettoställe och sådana grejer.

(Intervju med Amina)

Amina förhåller sig här till en bild av Malmö som folk lägger upp på sociala medier. Som framgår håller hon inte, utifrån egna erfarenheter, helt med om den bilden. För henne är Malmö en fin stad där människor tänker på varandra. Även Silvana ger uttryck för samma sak: "Jag förstår hur de tänker, ghettoställe [...] Men om vi bor på 
denna gården, så känner man alla gårdar i närheten”. Hon kopplar, precis som Amina, sin bild av Malmö till erfarenheter av sociala relationer i det egna närområdet, vilket är återkommande i samtliga intervjuer.

Malmö beskrivs ofta som en segregerad stad i förhållande till boende kopplat till ekonomi, sociala relationer och hälsa (t.ex. Kommissionen för ett socialt hållbart Malmö 2013). I intervjuerna frågas de medverkande därför om vad segregation betyder för dem. Innebörden av segregation utifrån svaren kan sammanfattas i 'att inte mötas', 'att leva i olika världar', 'att inte känna igen sig i den andre' och 'att leva med olika socioekonomiska villkor'. Det sistnämna kan till exempel handla om att man inte gärna besöker områden där man inte känner någon:

Adel: Jag vill till exempel inte gå till Västra hamnen.

Kalle: Vi alla kan.

Max: Men vi tre vill inte. Men jag vet inte om de andra, om de inte vill.

Intervjuare: Varför vill man inte det?

Kalle: Man vill bara inte umgås med andra som man inte känner. Som man inte är barndomsvän med.

Max: Det är ju alltid bra att lära känna nya personer men av någon konstig anledning så vill vi inte.

Adel: Varför ska man lära känna personer som är helt olika? Vi har inget gemensamt. Max: De bor i de finare områdena.

(Intervju med Max, Kalle och Adel)

Här uttrycker killarna att de inte vill umgås med personer som de inte känner. De hänvisar till ett område i staden som socioekonomiskt skiljer sig från deras eget, ett enligt dem "finare" område, och påpekar att de inte har något gemensamt med dem som bor där. Överlag framträder i intervjuerna en bild av att de medverkandes umgänge utgår från skolan och bostadsområdet. Till exempel svarar Karin på frågan om vilka områden som hennes vänner kommer från: Det är väl ungefär samma områden eftersom vi har gått på samma skola så har vi ju bott på ungefär samma ställe. Hur de medverkande unga umgås kan tolkas som att höra ihop med den allt mer segregerade staden, dvs. att de bor och umgås med dem som liknar dem själva (Salonen 2011). Hur ser då unga generellt sett på detta med segregation? I enkäten fick svarande ta ställning till påståendet, "Malmö blir allt mer segregerat utifrån att människor från olika bostadsområden och bakgrund inte umgås eller pratar med varandra".

Tabell 3. "Malmö blir all mer segregerat"

\begin{tabular}{ccc}
\hline & Antal & Procent \\
\hline Håller inte alls med & 76 & $17 \%$ \\
Håller med lite grann & 204 & $44 \%$ \\
Håller med mycket & 122 & $26 \%$ \\
Håller helt med & 58 & $13 \%$ \\
\hline
\end{tabular}


Som tabellen visar håller 39 \% mycket eller helt med om att Malmö blir allt mer segregerat, medan $16 \%$ inte alls håller med. Om man också räknar in håller med lite grann, pekar resultatet mot att majoriteten av de som svarat på enkäten, i större eller mindre grad, anser att människor från olika bostadsområden och med olika bakgrund lever segregerat. Det framgår ingen skillnad utifrån kön men boende i Limhamn/Bunkeflo håller i högre grad än övriga med om att Malmö blir allt mer segregerat.

\section{DET EGNA BOSTADSOMRÅDET}

I både intervjuerna och enkätstudien framkommer att de medverkande tycker om och känner sig trygga i de områden där de bor. I enkätstudien svarar $65 \%$ att de alltid känner sig trygga i sitt område, ( $\mathrm{jmf}$ med $3 \%$ som svarar att de aldrig/sällan känner sig trygga). Majoriteten svarar också positivt på frågor som handlar om att området där man bor är lugnt, fint och att de boende är trevliga mot varandra. Vad gäller oro för händelser i området är mycket få oroliga för sådant som inbrott, skadegörelse, knarkhandel, rån och överfall. Dock finns en skillnad utifrån kön. En betydligt större andel killar än tjejer anger att de alltid känner sig trygga i sitt bostadsområde. Tjejer är också mer oroliga för att bli utsatta för överfall jämfört med killar. Detta stämmer överens med resultat från andra studier som visar att tjejer oftare känner sig otrygga $\mathrm{i}$ det egna bostadsområdet, speciellt på kvällarna (Myndigheten för ungdoms- och civilsamhällesfrågor 2016, Blomdahl et. al. 2017). Det finns också skillnader utifrån var man bor. De svarande från Rosengård/Fosie upplever sitt område som mindre lugnt och fint jämfört med de från Limhamn/Bunkeflo och övriga. Däremot är tendensen den motsatta vad gäller frågor om social sammanhållning. Boende från Rosengård/ Fosie svarar i högre grad än de övriga två kategorierna att de boende skyddar varandra och att alla känner alla. En annan skillnad utifrån boende är att medverkande från Limhamn/Bunkeflo i högre grad än de övriga känner mycket stor oro för skadegörelse och överfall i området där de bor.

Att majoriteten av de medverkande, trots skillnaderna, känner sig trygga i sitt bostadsområde stämmer med andra studier som visar att barn och unga generellt sett trivs och känner trygghet i sitt område, oavsett dess status och karaktär (Andersson 2002; Gustafson 2006; Van der Burgt 2006; Harju 2013; Harju och Rasmusson 2013; Myndigheten för ungdoms- och civilsamhällesfrågor 2016; Ivert och Egnell i denna antologi). Studier visar också att känslan av trygghet i hög grad hänger ihop med sociala relationer. Det gäller särskilt om det kan kopplas till erfarenheter som går att placera i tid och rum och därmed till ett större sammanhang (Gustafson 2006; Van der Burgt 2006; Harju 2013; Harju och Rasmusson 2013). Detta framkommer också i intervjuerna. Till exempel svarar Angelica följande på frågan om hur hon skulle beskriva sitt område: 
I X-området så finns det mycket ungdomar som håller på med grejer som man kanske inte borde göra, men själv så känner jag inte att det är ett problem eller något som stör mig. Men om någon som typ bor i Västra hamnen skulle komma dit så hade de ju tyckt det var annorlunda. Men jag känner mig trygg där i alla fall, för jag känner alla, alla känner alla. [...] Så fort man går ut så kan man prata med vem som helst, alla ler mot varandra och sånt.

(Intervju med Angelica)

I Angelicas utsaga finns flera aspekter som visar på vikten av att kunna sätta sådant som händer i det egna bostadsområdet i ett sammanhang. Beroende på om man känner folk i ett område och om de känner igen dig, kan känslan av trygghet vara olika i förhållande till samma plats. Som när Angelica resonerar kring varför ungdomar från andra områden inte skulle känna sig trygga i hennes. Resonemanget kan förstås i förhållande till att det egna området ofta är ett välkänt område där man utvecklat sociala nätverk (Andersson 2002). En annan aspekt handlar om att ha en förståelse för varför vissa aktiviteter förekommer, till exempel varför någon säljer droger: "Jag känner ju folk som säljer och sånt. Men det är inte så att de skryter om det, de gör nog bara det för att de behöver pengarna till något. Jag har inget problem med det men det är ju synd om dem." (Intervju med Angelica)

Flera av de intervjuade unga bor i områden som i det offentliga talet ofta nämns som "utsatta". De själva uttrycker att det finns problem i områdena där de bor, men samtidigt är de måna om att poängtera de positiva sidorna. Positiva aspekter som kommer upp i intervjuerna är att det är lugnt, att man inte själv har blivit utsatt för något brott och att där finns, precis som Angelica ger uttryck för, sociala nätverk. Negativa aspekter är sådant som knarkförsäljning, bilbränder och stökigt på kvällarna. Andra negativa händelser har med poliser som stoppar en på gatan att göra. Till exempel berättar Jakob och Johan att det på sista tiden har varit oroligheter i området där Johan bor, och att det har lett till en ökad polisnärvaro som de uppfattar som "störig" och utpekande.

\section{DISKUSSION}

Utgångspunkten för detta kapitel är frågor som rör unga människors erfarenheter av Malmö. Det som framkommer är att de medverkande, oavsett kön och var de bor, generellt sett har positiva erfarenheter och tankar om Malmö som stad och sitt eget bostadsområde. Det positiva är i hög grad kopplat till sociala relationer och aktiviteter. Det är när platser förknippas med goda sociala innebörder som staden och det egna bostadsområdet uppfattas i positiva termer. Detta tycks hänga ihop med välkända och befintliga relationer som man har i skolan, i bostadsområdet, i familjen och med familjevänner och genom sociala aktiviteter. Resultatet visar också att medverkande, 
generellt sett, håller med om att Malmö är en allt mer segregerad stad vad gäller möten mellan unga från olika bostadsområden och med olika bakgrunder.

Även om de medverkande unga generellt sett är positivt inställda till Malmö som stad och till sitt bostadsområde, så finns det en medvetenhet om dess negativa sidor. Genom hela kapitlet går en tudelad bild av staden som en röd tråd. Det är tydligt att de medverkande i förståelsen av sin stad måste förhålla sig till både berättelsen om den och egna, positiva såväl som negativa erfarenheter. De rör sig mellan det Christensen (2003) kallar "emplaced" kunskap om staden och en "spatial" (rumslig) kunskap. Återkommande vad gäller den spatiala kunskapen är hur man uppfattar att Malmö framställs i medier. Rapporteringen anses i huvudsak fokuserar negativa aspekter såsom skjutningar, kriminalitet, våldsamheter, och ha en problemfokuserad beskrivning av vissa bostadsområden. Detta kan i sin tur förklara varför medverkande från Rosengård och Fosie i högre grad än unga från andra områden upplever att den problembaserade mediabilden påverkar dem negativt. En fråga att ställa är om de unga från områden som Rosengård och Fosie också får stå som symbol för hela Malmö, dvs att bilden av staden kopplas till berättelser om dessa områden och de boende, speciellt unga killar (jmf Sernhede 2011). I antologin Miljonprogrammet och media hävdar författarna att medier utifrån sina val av berättelser ger möjliga förståelse- och tolkningsramar till händelser och skeenden i samhället. De valda berättelserna utgör underlag för vardagliga samtal, och om samma negativa berättelser av vissa miljöer ständigt återupprepas, kan de bilda representativa förklaringar till förhållanden i samhället i stort (Ericsson m.fl. 2002). Berättelsen om 'förorten' och 'farliga unga' blir då representativa för Malmös problem och ger upphov till konkreta känslor och föreställningar av fara som också påverkar känslan av otrygghet i det vardagliga livet. När det saknas direkta erfarenheter från platser kan händelser och rykten också vara svåra att placera i ett större sammanhang och därmed också förhålla sig kritiskt till. Den problemfokuserade bilden av vissa områden kan då påverka känslan av otrygghet även i områden där tryggheten anses vara hög. Det är ett sådant resonemang som kan vara en förklaring till varför de medverkande unga från Limhamn/Bunkeflo, där den reella tryggheten anses vara hög (Ivert m.fl. 2015), i högre grad än övriga anger att de känner mycket stor oro för skadegörelse.

En annan fråga att ställa kopplat till den negativa bilden av vissa bostadsområden är hur den påverkar de boende i dessa områden? Medverkande från Rosengård och Fosie upplever till exempel att den problembaserade mediabilden påverkar dem negativt. Även andra studier visar att boende i liknande områden känner sig utpekade och stigmatiserade (Ericsson m.fl. 2002; Ristilammi 2006; Hallin m.fl. 2010; Stigendal 2011, 2016; Egnell och Ivert 2016). Till exempel visar Hallin m.fl. (2010) från en studie om Rosengård att röster från de boende i medierapporteringen i stort är osynliggjort eller hamnar i mediaskugga. Boende, såväl unga som vuxna, uttrycker också att det är de negativa bilderna och händelserna som dominerar mediabevakningen. Detta framkommer också i en samling noveller som elever på Apelgårdsskolan (Apelgårdsskolan 2019) har skrivit. I flera av novellerna som skrivits av eleverna i de högre årskurserna kretsar berättelserna, direkt och indirekt, om områdets dåliga rykte och om 
hur Rosengård på nätet och i tidningar framställs som farligt, kriminellt och otryggt. Eleverna skildrar i sina berättelser en mer nyanserad beskrivning av sitt område, där också skratt, glädje, positiva sociala relationer, grönområden och sammanhållning lyfts fram.

Även i detta kapitel upplever svarande från Rosengård/Fosie den sociala sammanhållningen som stark. Resultatet skiljer sig från andra studier som visar att det i områden där problemnivån upplevs som hög, ofta också finns en uppfattning om att den kollektiva styrkan är låg. Med kollektiv styrka menas då "social sammanhållning och tillit mellan de boende i ett område, samt deras förmåga att utöva kontroll för att upprätthålla gemensamma normer och agera tillsammans för områdets bästa" (Ivert m.fl. 2015:214). Det bör poängteras att resultatet bör tolkas med försiktighet då aspekter som att de boende skyddar varandra och att alla känner alla inte är tillräckliga mått på kollektiv styrka. Resultatet stämmer dock med andra studier där unga har kommit till tals. Till exempel visas i rapporten Samverkan för att lösa problem med innanförskapet att unga medverkande i ett så kallat "utsatt" område i Malmö framhåller en känsla av samhörighet som områdets största tillgång (Stigendal 2016b). Resultat är av intresse att diskutera i förhållande till att unga kan ha andra upplevelser än vuxna vad gäller kollektiv styrka. En förklaring kan vara att de rör sig mer i staden och i bostadsområden och att detta i sin tur kan ge större kännedom om, och fler sociala nätverk, vilket i sig kan vara trygghetsskapande. Kanske är det också så att unga i områden som Rosengård/Fosie på grund av trångboddhet och begränsade ekonomiska resurser i högre grad är hänvisade till att umgås utomhus i sitt bostadsområde (Harju 2008), och därmed till skapandet av och upprätthållande av sociala relationer och tilllit. Oavsett, är det intressant att vidare undersöka den kollektiva styrkan utifrån ungas perspektiv, både inom och mellan bostadsområden. Detta för att, som också påpekas i flera av antologins kapitel, på sikt kunna öka tryggheten i områden med höga nivåer av otrygghet och för att minska polariseringen mellan områden.

Avslutningsvis, pekar resultatet mot att unga från bostadsområden med olika socioekonomiska bakgrunder lever segregerat och sällan möts. Det går i linje med resultat från Malmö kommissionens rapport (2013) och med resultat i rapporten Segregation och segmentering i Malmö (Salonen m.fl. 2019). Den sistnämnda rapporten visar på en tydligt uppdelad stad utifrån socioekonomisk segregation. I den påpekas dock att utvecklingen inte endast gäller för Malmö, utan att segregationen är ett generellt fenomen i samhället snarare än ett Malmöproblem. I materialet som detta kapitel utgår ifrån går det att utläsa att det finns ett intresse hos unga från olika bostadsområden att mötas. I intervjuerna lyfts känsla av gemenskap fram som särskilt viktigt för viljan att möta andra, och att den känslan kan uppstå när man strävar mot samma mål, har gemensamma intressen och erfarenheter. Genomgående är dock att ansvaret för skapandet av dessa möten anses ligga på de vuxna. Unga tycks inte riktigt själva få till stånd möten som går över olika synliga och osynliga gränser. Det ställs således stora krav på vuxna att möta upp i detta, och jag vill avsluta kapitlet genom att återkomma till Masseys (2005) begrepp throwntogetherness, som utgår från att städer aldrig kan ses som att de har en sammanhängande, given och förutbestämd identitet, tvärtom 
är de till sin natur heterogena, intensiva och ojämlika. Utmaningar och komplexitet är utifrån detta perspektiv en normalitet och inte ett tillfälligt tillstånd, vilket kräver vuxna som på allvar antar en utmaning som handlar om komplexa förhandlingar om mångfald.

\section{REFERENSER}

Andersson, Björn (2002). Öppna rum: om ungdomarna, staden och det offentliga livet. Göteborgs universitet: Institutionen för socialt arbete.

Apelgårdsskolan (2019). Det hände i Rosengård... Novellsamling från elever på Apelgårdsskolan.

Van der Burgt, Daniella (2006). "Där man bor tycker man att det är bra". Barns geografier i segregerade stadsmiljöer. Geografiska regionsstudier: Uppsala universitet.

Blomdahl, U., Elofsson, S., Bergmark, K och Lengheden, L. (2017). Ung livsstil Malmö. En studie av unga ungdomar i högstadiet. Malmö stad.

Bunar, Nihad och Sernhede, Ove (red.) (2013). Skolan och ojämlikhetens urbana geografi. Om skolan, staden och valfriheten. Göteborg: Bokförlaget Daidalos

Chawla, L. och Malone, K. (2003). Neighbourhood quality in children's eyes. I: Christensen, Pia och O'Brien, Margaret (red.). Children in the City: Home, Neighbourhood and Community. New York: Routledge.

Christensen, Pia och O'Brien, Margaret (2003). Children in the City. Home, Neighbourhood and Community. London and New York: Routledge.

Egnell, Susanne och Ivert, Anna-Karin (2016). Flera nyanser av trygghet. En studie om oro och för brott i Herrgården. Institutionen för kriminologi, Malmö högskola.

Ericsson, Urban, Molina, Irene och Ristilammi, Per-Markku (2002). Miljonprogram och media. Föreställningar om människor och förorten. Integrationsverket och Riksantikvariatämbetet: Norrköping respektive Stockholm.

Gustafson, Katarina (2006). Vi och dom i skola och stadsdel. Barns identitetsarbete och sociala geografier. Uppsala Studies in Education nr. 111. Uppsala universitet: Pedagogiska institutionen.

Hallin, Per-Olof, Alban Jashari, Carina Listerborn och Margareta Popoola (2010) Det är inte stenarna som gör ont. Röster från Herrgården, Rosengård - om konflikter och erkännande. Mapius: Malmö högskola.

Harju, A. (2017). Children practising politics through spatial narratives Children's Geographies. Publisher: Taylor\&Francis.

Harju, A och Rasmusson, B (2013). Stadsbarndom: om barns erfarenheter av platser i staden [Urban Childhood: Children's Experiences of Places in the City]. Barn. 
Forskning om barn og barndom i Norden, 2013, Issue 2 (pp: 23-36).

Harju, A (2013). Children's Use of Knowledge of Place in Understanding Social Relations. Children \& Society, 03/2013, Volume 27, Issue 2 (pp: 150-160).

Harju, Anne (2008). Barns vardag med knapp ekonomi. En studie om barns erfarenheter och strategier. Växjö: Linnéuniversitetet.

Kommissionen för ett socialt hållbart Malmö (2013). Malmös väg mot en hållbar framtid. Hälsa, välfärd och rättvisa. Slutrapport, Malmö stad.

Ivert, Anna-Karin, Torstensson Levander, Marie och Mellgren, Caroline (2015). Den ojämlika otryggheten - stabilitet och förändring i bostadsområden över tid. Socialvetenskaplig tidskrift 2015:3-4.

Johansson, Magnus; Righard, Erica, och Salonen, Tapio (eds.) Social Transformations in Scandinavian Cities. Lund: Nordic Academic Press.

Malmö stad (2017). Statistik och fakta [http://malmo.se/kommunpolitik/faktaochstatistik/befolkning/aldersstruktur.4.4cc94c3815be8cd0d0b5f97.html]. Hämtat: 2017-11-09.

Massey, Doreen (2005). For Space. London: SAGE.

Massey, Doreen (1994). Space, Place and Gender. Minnesota: University of Minnesota Press.

Myndigheten för ungdoms- och civilsamhällesfrågor (2016). Ung idag 2016. En beskrivning av ungas levnadsvillkor. Stockholm

Ristilammi, Per-Markku (2006). Memento Rosengård, i Serhede, Ove och Johansson, Thomas (red.), Storstadens omvandlingar. Postindustrialism, globalisering och Migration. Göteborg och Malmö. Göteborg: Bokförlaget Daidalos.

Salonen, Tapio, Grander, Martin och Markus Rasmusson (2019). Segregation och segmentering i Malmö. Malmö: Stadskontoret, Kansliet för hållbar utveckling.

Salonen, Tapio (2011). "En blågul stad" Myter och sanningar om staden, i Salonen, Tapio (red.) Hela staden. Social hållbarhet eller deintegration? Umeå: Borea Bokförlag

Stigendal, Mikael (2016a). Samhällsgränser: ojämlikhetens orsaker och framtidsmöjligheterna i en storstad som Malmö. Malmö: Liber

Stigendal, Mikael (2016b). Samverkan för att lösa problem med innanförskapet. Rapport från en förstudie Stigendal. Malmö: Malmö högskola.

Mikael Stigendal, red. (2011) "Det handlar om något större". Kunskaper om ungdomars möte med sin stad. Följeforskning om New City. Mapius: Malmö högskola.

Stigendal, Mikael (1999). Sociala värden i olika sociala världar. Segregation och integration $i$ storstaden. Lund: Studentlitteratur. 


\section{Att navigera i ett villkorat stadsrum. Malmötjejer om (o)tillhörighet, rörelsemöns- ter och platsskapande}

Johanna Sixtensson

\section{INLEDNING}

Det här kapitlet tar sin utgångspunkt i en grupp tonårstjejers berättelser om deras vardagsliv i Malmö. Texten kan också sägas skildra det segregerade Malmö och de olika livsvillkor som råder i staden. Medan tjejers mångfacetterade erfarenheter inte har beretts tillräckligt mycket utrymme, vare sig forskningsmässigt eller sett till den allmänna diskursen, kan Malmös problem beskrivas vara att dess dominerande narrativ är exkluderande. Många röster fattas, saknar representation eller hamnar i skymundan. I det här kapitlet ges utrymme för några av dessa viktiga berättelser. Med utgångspunkt i tonårstjejers intervjuutsagor om vardagen i Malmö kommer jag att diskutera och ge exempel på hur sociala maktstrukturer tar sig rumsliga uttryck och skapar ett stadsrum som kan beskrivas som villkorat. Villkorat i den meningen att stadsrummet är etniskt och ekonomiskt segregerat (t.ex Hedman och Andersson 2016; Molina 2016; Andersson och Turner 2014), men också villkorat i den meningen att effekterna av dessa strukturer inverkar på individers rörelsemönster och känslor av tillhörighet. I texten skildras hur tjejers vardagsliv kan skilja sig åt beroende på faktorer som ekonomisk position, vilket område av staden de bor i samt beroende på huruvida de har erfarenheter av att konstrueras som "icke-svenska". Texten kommer också ge några exempel på gemensamma erfarenheter av att vara tjej i Malmö, där de gemensamma dragen kommer ur mötet med kön som maktrelation. Kapitlet baserar sig på min avhandling, Härifrån till framtiden. Om gränslinjer, aktörskap och motstånd $i$ tjejers vardagsliv (2018), och resonemang jag för i denna text kan hittas i mer utvecklade former där.

Varför är det då relevant att studera tonårstjejers vardagsliv? Jag menar att det är av vikt att som forskare inte bara utforska uppseendeväckande problem, stora händelser, eller den extrema utsattheten. Vi behöver också lyssna till det som kan tyckas 
alldagligt eller vanligt, då vardagliga praktiker säger mycket om individers livsvillkor och levnadsförhållanden. Att studera vardagen kan med andra ord vara ett sätt att studera maktrelationer (t.ex. Smith 1987; Hochshild 1989) och genom att sätta individers olika vardagsliv i jämförelse med varandra kan intressanta skillnader utkristallisera sig. Ingången i vardagen som studiefält har för mig också varit en reaktion på den tendens som finns i att framställa tjejer i tonåren som en homogen riskgrupp, särskilt utsatta för psykisk ohälsa (Ambjörnsson 2004; Kvist Lindholm 2015; Rönnbäck 2015). Att utforska vardagslivet är därför en strategi som skapar förutsättningar för att upptäcka många olika processer som formar tjejer och deras vardag.

\section{TEORIER OM RUM, KROPP, RÖRELSE OCH MAKT}

I texten som följer är tjejernas upplevelser av olika platser och rum central. I linje med teoretikern Sara Ahmed $(2010,2006)$ argumenterar jag för att det vardagliga livet sker i och genom rummet. Genom att göra analytiska och teoretiska kopplingar mellan kroppars upplevelser av och rörelser i olika rum skapas förutsättningar för att få syn på maktordningar (Sixtensson 2018). Att tala om kroppar, när det i själva verket är människor, är ett teoretiskt grepp för att fånga just upplevelsers förkroppsligande logiker. Genom detta synsätt går det att förstå hur till exempel mötet med en diskriminerande handling upplevs genom kropp såväl som sinne och påverkar kroppen i dess fortsatta handlingar, känslor och rörelser (Ahmed 2010). Ahmeds teoribildning skapar förutsättningar för att begripliggöra hur samhälleliga normer och ideal påverkar upplevelsen av eller känslan för olika rum, till exempel om vi känner tillhörighet, olust eller exklusion. Känslan för rum kan i sin tur påverka individers rörelsemönster, till exempel i staden. Vissa rum kanske undviks medan andra beträds med självklarhet och "känns som hemma". Detta är processer genomsyrade av maktstrukturer: klassbakgrund, etnicitet, men också kön spelar roll för var vi känner oss hemma, eller tillåts känna oss hemma. Vissa kroppar har med andra ord privilegiet att känna sig hemma i fler rum än andra och kan i högre grad, som Ahmed uttrycker det, "röra sig med lätthet", det vill säga med lägre risk att ifrågasättas, övervakas eller stoppas i sin rörelsebana (ibid). Med ett öga på upplevelsen av rum och rumslighet går det således att upptäcka de gränslinjer som platser och rum skapar, men också vilka rum som upplevs som trygga och "hemma" och varför (Sixtensson 2018). Detta tankesätt utgör den teoretiska och analytiska utgångspunkten i kapitlet. 


\section{METOD I KORTHET}

Det empiriska materialet som ligger till grund för texten kommer ur fokusgrupper, halvstrukturerade enskilda intervjuer och intervjuer i par med 22 tjejer mellan 16 och 19 år. Urvalskriterierna var ålder, kön och att deltagarna skulle vara boende i Malmö. Jag sökte aktivt deltagare som bodde i olika delar av staden då jag arbetade utifrån hypotesen att deras olika geografiska positioner, givet Malmös segregerade karaktär, skulle bidra med intressanta kontraster sett till materialet i stort. De tjejer som deltog i studien bor således i olika stadsområden och de har också olika ekonomiska hemförhållanden. Ungefär hälften av tjejerna beskriver dessutom erfarenheter av att kategoriseras som "icke-svenska". Dessa skillnader kommer att vara av analytisk vikt $\mathrm{i}$ texten som följer. Deltagarna rekryterades via gymnasieskolor men också via olika ungdomsprojekt i Malmö stad. I de tre fokusgrupper som genomfördes i studien fanns vissa inbördes relationer. I en fokusgrupp (fokusgrupp 1) var deltagarna både klasskamrater och vänner samt uppväxta i samma bostadsområde i sydöstra Malmö. I en annan (fokusgrupp 2) var tjejerna också bekanta med varandra genom ett ungdomsprojekt och var boende i samma område i sydöstra Malmö. I den tredje fokusgruppen var tjejerna till viss del bekanta med varandra genom att de deltagit $i$ ett kortare ungdomsprojekt. De hade ingen annan anknytning till varandra och bodde i olika delar av Malmö, majoriteten i de västra delarna av staden. Alla de deltagande tjejerna är anonymiserade och de namn som används i texten är fingerade.

\section{NÄR BOSTADSOMRÅDET GÖR SKILLNAD}

Hypotesen att tjejernas geografiska spridning i olika bostadsområden i Malmö skulle medföra berättelser av skilda slag visade sig stämma. Ett exempel på en sådan skillnad är hur diskurser om Malmös olika bostadsområden påverkar tjejerna på olika sätt beroende på var i Malmö de bor. Materialet visar till exempel att de deltagare som bor i de ekonomiskt starkare västra delarna av Malmö inte reflekterar särskilt mycket över betydelsen av detta. De tjejer som bor i områden som, för att använda deras egna ord, "har ett dåligt rykte" är väl medvetna om att områdets negativa stämpel spelar roll för hur de uppfattas när de rör sig utanför området. I en fokusgrupp beskriver en tjej som heter Adela att hon uppfattar det som att hon och andra från hennes stadsdel inte är "lika mycket värda". Hon tror att det är svårare att få jobb för personer som kommer från hennes område och än mer så om "du är invandrare". I citatet som följer beskriver Adela en händelse där hon själv fått uppleva detta:

Adela: Jag kommer inte ihåg var jag var, jag var i stan och då frågade kvinnan så, där jag lämnade mitt CV, och så såg hon min adress och så frågade hon 'var ligger 
det, vilken stadsdel tillhör det?' Då sa jag (stadsdelens namn, min anm.) och så sa hon 'jaha, men jag ska lägga detta papper åt sidan så ska vi kolla igenom det' och samtidigt som hon sa det så slängde hon det, pappret.

Johanna: Du såg att hon slängde det?

Adela: Ja.

(Ur fokusgrupp2)

Att kvinnan som tog emot Adelas CV kastade det i papperskorgen när Adela berättade var hon bor kan förstås genom urbansociologens Loic Wacquants (2007) begrepp territoriell stigmatisering. Territoriell stigmatisering är en marginaliseringsprocess som innefattar vissa stadsområden eller förorter, men också omfattar de individer som bor där. Dessa områden är ofta socioekonomiskt svagare och har en högre andel individer med migrantbakgrund, vilket är en konsekvens av segregeringens processer. Genom det territoriella stigmats förlopp sker ett slags kollektivt skuldbeläggande av dessa områden. Parallellt hålls individerna som bor där ansvariga för problem som i egentlig mening är övergripande strukturella samhällsproblem (Sernhede 2009). Många av de tjejer som bor i områden som Adelas uttrycker precis som hon att de upplever att områdets negativa stämpel påverkar dem på olika sätt i vardagen, inte minst genom möten med fördomar. Tjejerna använder olika strategier för att hantera detta, som att undvika att säga vilket område de bor i eller säga att de bor i ett annat närliggande område som inte har lika dåligt rykte. Viktigt att poängtera är dock att tjejernas upplevelser av att bo och leva sina vardagliga liv i dessa områden är mångsidiga och inte nödvändigtvis negativa. Hemområdet, oavsett dess rykte, har en viktig social och kollektiv roll (se också Hagström 2018, Lundström 2007). Parallellt med berättelser om mötet med fördomar finns också berättelser som är av en helt annan karaktär. Tjejerna beskriver nämligen också deras bostadsområden som fyllda av gemenskap, tillhörighet och trivsel och försvarar i våra samtal bostadsområdet gentemot negativa diskurser (jmfr van der Burgt 2006; Harju i denna antologi). Dessa motberättelser, vill jag argumentera för, är särskilt viktiga för att nyansera bilden av områden som stämplas i negativ bemärkelse, och de människor som lever sina vardagliga liv där.

De tjejer som jag samtalar med och som bor i Malmös mer välbärgade områden beskriver som nämnt inte upplevelser av stigman som bostadsområden kan utgöra. Däremot finns det i deras berättelser element som visar att även deras bostadsområden kan definiera dem på olika sätt. Den viktiga skillnaden är dock att deras bostadsområden för med sig föreställningar om att "flytta upp", "pappa betalar" eller "du är rik", vilket är antaganden som sänder ut signaler om att invånarna där har högre samhälleliga positioner. I avhandlingen beskriver jag det som att dessa områden istället för stigma skapar status, vilket kan leda till fördelar för de individer som bor där (Sixtensson 2018). I Malmö är de socioekonomiska klyftorna mellan olika bostadsområden mycket stora (Salonen m.fl. 2019). Detta för med sig materiella skillnader, samt också skillnader sett till hälsa vilket påvisats av Malmökommissionen (2013). Vad jag har velat synliggöra i denna sektion är att segregationens mekanismer också leder till starka förställningar om stadens olika bostadsområden. Också dessa inverkar på vardagens villkor och kan få högst påtagliga följder, som för Adela. I nästa passage 
vänder jag blicken mot hur platser och rum kan ha en "talande" roll som skillnadsskapande markör.

\section{EKONOMISKA SKILLNADER OCH PLATSBUNDEN (O) TILLHÖRIGHET}

De deltagande tjejernas vardagsekonomiska hemförhållanden ser olika ut. Deras ekonomiska positioner stämmer också ofta överens med var de statistiskt sett kan förväntas att bo i staden. Majoriteten av deltagarna med goda eller mycket goda ekonomiska hemförhållanden bor till exempel i de västra delarna av Malmö, där höginkomsthushållen är fler än i andra delar av staden (Scarpa 2015). Genom att sätta intervjuberättelser om ekonomiskt knappa hemförhållanden mot berättelser om mycket goda ekonomiska hemförhållanden synliggörs stora skillnader i vardagens villkor, till exempel vad som är möjligt att konsumera och göra. Ett tydligt mönster är hur tjejerna läser in och förstår skillnad mellan olika individer och grupper genom olika konsumtionspraktiker och ideal kring konsumtionspraktiker. Kläder men också resor och inredningsdetaljer används genomgående i beskrivningarna för att markera skiljelinjer mellan människor. Vad jag också kan utläsa av tjejernas berättelser är hur beskrivningar av olika områden i staden också genomsyras av en ekonomisk terminologi, de talar om "dyra och billiga ställen" eller beskriver platser eller områden som "finare" eller "snobbiga". I citatet som följer framställer en tjej som heter Frida under en intervju hur plats och rum kan tolkas som just "dyra" alternativt "billiga" och hur hennes läsning av platsen påverkar var hon vistas och inte:

Lilla torg känner jag mig inte hemma på, där är alldeles för dyrt att vara och jag gillar Södervärn för där är också billigt. Jag gillar billiga ställen för jag har ju inte så mycket pengar. Jag hör ju mest hemma vid Triangeln, vid Södervärn, vid Gustav, det är där jag oftast är.

Frida beskriver i citatet hur hon väljer bort Lilla torg eftersom hon varken anser att hon har råd att handla där eller känner sig hemma där. Det finns dock andra tjejer i min studie som tvärt emot Frida ofta spenderar tid på just Lilla torg. Under en intervju berättar Linn att hon ofta träffar sina kompisar där: "Lilla torg brukar vi mest vara på, det är vårt ställe, verkligen". Det här torget är beläget i de centrala delarna av Malmö, men vetter mot de västra stadsdelarna. I anslutning till torget finns shoppingstråk med butiker av det exklusivare slaget och torget ramas in av restauranger och barer. Vad jag vill argumentera för här är hur rummet, som i det här fallet kan beskrivas som ett kommersiellt rum, har en "talande roll" i konstruktioner av skillnad (Sixtensson 2018). Platser, såsom olika stadsrum, är inte neutrala utan bär på symbolik som 
individer tolkar och förhåller sig till. Det platsen står för, eller signalerar, kan skapa platsbunden tillhörighet ("det är vår plats") eller platsbunden o-tillhörighet ("där känner jag mig inte hemma"). Ahmed (2006; 2010) illustrerar den invanda följdriktigheten som finns i vårt sätt att röra oss mot det vi känner igen och det som upplevs som familjärt. Enligt samma mönster undviker vi, eller rör oss bort från, sådant som upplevs främmande eller otryggt. Att Frida väljer bort en plats som signalerar exklusivitet och dyra varor till förmån för ett område som mer motsvarar hennes ekonomiska position kan förstås som en rörelse mot ett rum som i högre grad får henne att känna sig hemma.

Det empiriska materialet visar också att tillgången till pengar inte automatiskt medför att offentliga platser och stadsrum, så som affärer, upplevs som åtkomliga. Även konstruktioner av "svenskhet" och "invandrarskap" inverkar nämligen på känslor av tillhörighet och rörelsemönster i staden. Svenskheten (såväl som invandrarskapet) används återkommande som markör för att beskriva grupper av människor, men också vissa platser i staden. Områden eller platser beskrivs som "svenska platser" eller ett "svenskt område". Svenskheten blir i relation till rum ett sätt att beskriva skiljelinjer mellan olika områden och offentliga platser. Många av de tjejer som har erfarenheter av att konstrueras som "icke-svenska" berättar att de återkommande känner sig övervakade och misstänkliggjorda när de handlar i butiker eller till exempel ska äta på vissa restauranger. Även delar av stadsrummet beskrivs som potentiellt riskfyllda att beträda som konstruerat "icke-svensk". Idén om att vissa platser och rum är förenade med risker för vissa grupper kan i en Malmökontext jämföras med Listerborn (2015) och Sixtensson (2009) där det framkommer att kvinnor med slöja undviker vissa platser och stadsrum av rädsla för att utsättas för våld eller trakasserier. Även offentliga platser och rum, så som Lilla torg, skapar med andra ord gränslinjer och är genomsyrade av maktrelationer vilka kan upplevas både inkluderande och exkluderande beroende på de ideal och normer som är maktbärande i de olika rumsliga sammanhangen. Att konstrueras som "icke-svensk" men vistas på vad som upplevs som en "svensk plats", för att återknyta till tjejernas berättelser, kan ge upphov till obehag men också reella risker att övervakas eller misstänkliggöras om ens kropp inte tillhör den på platsen maktbärande normen (Ahmed 2010a)

Hittills har jag diskuterat några av de skillnadsskapande processer som är i görning i stadsrummet och som inverkar på de deltagande tjejernas vardagsliv på olika sätt. I denna passage har ambitionen varit att ge prov på hur platser och rum bär på symbolik vilket påverkar kroppars upplevelser av att vistas där. I nästkommande passage ska jag istället diskutera några av de erfarenheter som spänner över den deltagande gruppen i stort, nämligen förhandlingarna med kön som ojämlik struktur. Också i denna passage ligger fokus på rumslighet och jag lägger medvetet emfas på tjejers initierade strategier att kringgå könshierarkiska mönster och skapa plats åt sig själva. 


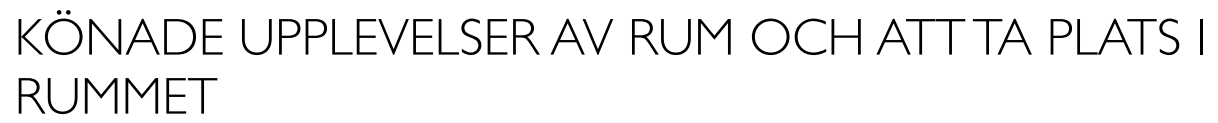

I studien har jag varit intresserad av att även utforska de deltagande tjejernas upplevelser av rum på ett sätt som sträcker sig bortom deras förhandlingar med socioekonomiska skillnader, konstruktioner av svenskhet och bostadsområdets status till att också utforska vilka strategier de använder för att ta plats i rummet. I tjejernas intervjuutsagor tar sig kön som hierarki till exempel uttryck genom beskrivningar av sexualiserad ryktesspridning av tjejer och genom förhandlingar med könade normer och ideal. Dessa erfarenheter spänner över gruppen i stort och kan därför förstås som gemensamma. I intervjuutsagorna tar sig ojämlika könsstrukturer dessutom uttryck genom berättelser om killar som tar vissa rum och platser i besittning, på sätt som gör att tjejerna ibland direkt eller indirekt hindras tillträde till vissa rum. En grupp tjejer berättar till exempel om en fritidsgård som intagits av killar till den grad att inga tjejer går dit och en annan grupp berättar om en elevorganisation på deras skola där bara killar får vara med. Oftare ger dock tjejernas berättelser uttryck för vad som kan karaktäriseras som anpassade strategier för att hantera killars närvaro. I citatet som följer exemplifieras detta genom en grupp tjejer som beskriver hur vissa gator och utrymmen i deras stadsdel intas av killgäng vilka de benämner "gatukillar". Dessa killars närvaro leder till att tjejerna rättar sitt rörelsemönster efter var killarna håller till:

Leila: De (killgängen, min förklaring) tar olika ställen hela tiden, från ett till tre är de utanför gymmet, från tre till fem är de utanför videoaffären, från fem till sju

Leila och Kamila: utanför ICA.

Leila: Från sju till nio affären, från nio till tre på natten är de utanför kiosken.

Kamila: Sen vaknar de upp sju.

Leila: Nej, nej, nej. Det sjuka är att alla inte går hem och sover, de delar upp tiderna. Sana: Vissa sover, vissa är ute, sedan byter de, typ skift.

(...)

Leila: Och vi känner till deras system "Ah vi kan inte gå till ICA, vi går till (hör ej ord)" i stället.

(Ur fokusgrupp 1)

Citatet skildrar hur tjejerna upplever att dessa killar "tar olika ställen" vid olika tidpunkter på dygnet vilket leder till att tjejerna, eftersom de "känner till deras system", strategiskt väljer rutter där de undviker att möta dem. Detta kan förstås som ett rumsligt rörelsemönster som är anpassat efter, och därmed begränsat av, killarnas rörelsemönster. En viktig poäng att göra, och som jag ser som särskilt viktig att understryka, är att tjejerna reagerar aktivt och inte passivt på killarnas maktövertag i rummet. De anpassar visserligen sitt rörelsemönster men denna anpassning innehåller också agens (d.v.s. handlingskraft). De hittar alternativa vägar att gå när gångvägen spärras av killgäng, eller söka sig till andra ställen att umgås på när fritidsgården, av samma anledning, inte är ett alternativ, som exemplifierat i citatet. Andra studier har också 
visat på tjejers kreativa förmågor att "ta plats" och använda sig av olika strategier för att undvika, kringgå eller utmana killars makt i olika rum. Christensen och Mikkelsen (2013) visar till exempel hur tjejer skapar rum, eller "egna platser", genom att röra sig i större grupper i rummet. Den kollektiva gemensamma rörelsen skapar trygghet såväl som meningsfullhet. Palmgren (2016) i sin tur argumenterar för att tjejers rumsanvändande är "taktiskt", de väljer att umgås på offentliga platser som skapar en känsla av privat och gömd atmosfär. Dessa platser, eller "mellanrum" (min översättning), menar hon, behöver inte nödvändigtvis vara platser i skymundan, folkmassor i rörelse kan också bidra till en känsla av att ha en egen plats att vara på eftersom massan av folk kan skapa en anonym känsla. Jag nämnde tidigare att jag ser det som särskilt viktigt att visa på tjejernas handlingskraft, i relation till de begräsningar de möter. Att inte kunna "röra sig med lätthet" (Ahmed 2010, s.64), innebär inte att en inte kan röra sig alls, ta plats, eller göra motstånd. Att framhäva exempel på detta i text är angeläget eftersom det fungerar som motbilder mot diskurser om tjejer och kvinnor som passiva och orörliga (t.ex. Azzarito m.fl. 2006).

\section{AVSLUTANDE ORD}

I kapitlet har ambitionen varit att diskutera några aspekter av de komplexa nät av socio-rumsliga skillnader som råder i Malmö och som präglar den deltagande gruppen tjejers vardagsliv. Genom deras berättelser har jag exemplifierat hur maktstrukturer och skillnadsskapande processer tar sig rumsliga uttryck samt hur platser och rum bär på starka föreställningar om vem som bor där eller vem platsen är till för. I texten åskådliggörs hur konstruktioner av svenskhet, ekonomisk position, men också kön som maktordning påverkar tjejernas känslor av (o)tillhörighet samt rörelsemönster i stadsrummet. Tjejerna som deltar i studien möter olika strukturella hinder i vardagen, men delar också vissa erfarenheter. Genom deras berättelser ges också några exempel på hur tjejerna på olika sätt hanterar maktordningar och hur de navigerar i en stad som inte alltid bjuder in till obehindrad rörelse.

Tjejernas berättelser säger något om den plats och den samtid som de talar ifrån och som de formats av.

Deras röster väcker viktiga frågor om ojämlikheten i Malmö i stort och deras erfarenheter bör inte minst förstås i ljuset av boendesegregationens etniska så väl som ekonomiska uttryck (t.ex. Hedman och Andersson 2016; Molina 2016; Andersson och Turner 2014). Kanske bör deras berättelser dock särskilt betänkas i relation till barn- och ungdomspositionen. I min studie är berättelser om att känna sig mindre värd i samhället för att ens kropp läses som "icke-svensk" och/eller för att ens bostadsområde anses vara ett dåligt område vanliga. Hur är det att som ung växa upp med den känslan? Vad gör den med den unges syn på det egna jaget eller hens tankar på framtiden? Det är viktiga frågor att begrunda, men de manar också till handling. 
Åtgärder som motverkar de ojämlika mönster som råder i staden och dess inverkan på barn och unga behövs och bör ske på olika nivåer och inkludera allt från beslutsfattare till tjänstemän och praktiker, men också den bredare allmänheten. Alla har vi ett ansvar att tillvarata och främja barn och ungas lika värde och rättigheter.

Jag skrev inledningsvis om röster som saknar representation och berättelser som är ensidiga. Genom att tillfråga tjejer om vardagens villkor i Malmö har jag försökt att skapa textmässigt utrymme för några av dessa kompletterande berättelser. Det finns dock fler berättelser att lyssna till. Kunskap om olika levnadsvillkor, hur de skapas och upplevs, och vilka konsekvenser de för med sig för barn och unga är centrala för att kunna förebygga sociala problem och socialt utestängande.

\section{REFERENSER}

Ahmed, Sara (2010a). Vithetens fenomenologi i Tidskrift för Genusvetenskap. Nr.1-2, s.47-69.

Ahmed, Sara (2006). Queer phenomenology: orientations, objects, others. Durham, N.C.:Duke University Press.

Ambjörnsson, Fanny (2004). I en klass för sig. Genus, Klass och sexualitet bland gymnasietjejer. Stockholm: Ordfront förlag.

Andersson, Roger och Hedman, Lina (2016). Economic decline and residential segregation: a Swedish study with focus on Malmö i Urban Geography, vol. 37, nr. 5, sid. 748-768.

Andersson, Roger och Turner, Lena M. (2014). Segregation, gentrification, and residualisation: from public housing to market-driven housing allocation in inner city Stockholm i International Journal of Housing Policy. Vol. 14, nr. 1, s. 3-29.

Azzarito, Laura, Solmon, Melinda A. och Harrison Jr., Louis (2006). “...If I Had a Choice, I Would...." A Feminist Poststructuralist Perspective on Girls I Physical Education, Research Quarterly for Exercise and Sport. Vol. 77, nr 2, s. 222-239.

Grundström, Karin och Molina, Irene (2016). From Folkhem to lifestyle housing in Sweden: segregation and urban form, 1930s-2010s i International Journal of Housing Policy, vol.16, nr 3, s. 316-336.

Hagström, Mirjam (2018). Raka spår, sidospår, stopp: Vägen genom gymnasieskolans

språkintroduktion som ung och ny i Sverige. Diss. Linköpings universitet.

Kvist Lindholm, Sofia (2015). The Paradoxes of Socio-Emotional Programmes in School: Young people's perspectives and public health discourses. Diss. Linköping: Linköpings universitet. 
Listerborn, Carina (2015). Geographies of the veil: violent encounters in urban public spaces in Malmö, Sweden i Social and Cultural Geography. Vol. 16, nr. 1, s. 95-115.

Listerborn, C., Grundström, K., Claesson, R., Delshammar, T., Johansson, M., \& Parker, P. (red) (2014). Strategier för att hela en delad stad: samordnad stadsutveckling $i$ Malmö. Malmö: Malmö University.

Lundström, Catrin (2007). Svenska latinas. Ras, klass och kön i svenskhetens geografi. Göteborg: Makadam.

Palmgren, Ann-Charlotte (2016) Teenaged Girls and Liminal Spaces in Turku. Research Briefings 3/2016, City of Turku/Turku Urban Research Program.

Ringrose, Jessica (2008). Every time she bends over she pulls up her thong. Teen girls negotiating discourse of competitive, heterosexualised aggression i Girlhood studies. Vol 1, nr. 1, s. 33-59.

Rönnbäck, Julia (2015). Det är väl typiskt tjejer: om basket, kropp och femininitet. Diss. Malmö: Malmö högskola.

Salonen, Tapio, Grander, Martin och Markus Rasmusson (2019). Segregation och segmentering $i$ Malmö. Malmö: Stadskontoret, Kansliet för hållbar utveckling.

Scarpa, Simone (2015). The impact of income inequality on economic residential segregation: The case of Malmö, 1991-2010 i Urban Studies. Vol. 52, Nr. 5, s. 906 $-922$.

Sernhede, Ove (2009). Territoriell dtigmatisering, ungas informella lärande och skolan i det postindustriella samhället i Utbildning \& demokrati, vol. 18, nr.1, s. 7-32.

Sixtensson, Johanna (2018). Härifrån till framtiden: om gränslinjer, aktörskap och motstånd i tjejers vardagsliv. Diss. Malmö: Malmö universitet.

Sixtensson, Johanna (2009). Hemma och främmande i staden: kvinnor med slöja berättar. Malmö: Institutionen för urbana studier, Malmö högskola.

Smith, Dorothy E. (1987). The everyday world as problematic: a feminist sociology. Boston: Northeastern University Press.

van der Burgt, Danielle (2006). "Där man bor tycker man det är bra": barns geografier i en segregerad stadsmiljö. Diss. Uppsala: Uppsala universitet.

Wacquant, Loïc (2007). Territorial stigmatization in the age of advanced marginality i Thesis Eleven. Vol. 91, nr. 1, s. 66-77. 


\section{"Det har inte med mig att göra" - om unga killars upplevelser av otrygghet i det offentliga rummet}

Susanne Egnell \& Anna-Karin Ivert

\section{INTRODUKTION}

Intresset för frågor som rör otrygghet och utsatthet för brott är stort i den offentliga debatten och åsikterna om varför vissa individer och platser är mer otrygga än andra är många. Även inom forskningen finns det ett växande intresse för att förklara variationer i individers trygghetsupplevelse. Idag genomförs regelbundet trygghetsmätningar både på nationell och lokal nivå och dessa används ofta som utgångspunkt i diskussionen om huruvida otryggheten i samhället ökar eller minskar och som underlag för det trygghetsskapande arbetet. Såväl det trygghetsskapande arbetet som forskningen om otrygghet tar i de allra flesta fall sin utgångspunkt i vuxnas erfarenheter och uppfattning om vad som gör det offentliga rummet eller bostadsområdet tryggt eller otryggt. I den här texten vill vi istället fokusera på ungdomars trygghetsupplevelse i bostadsområdet och det offentliga rummet, och mer specifikt på unga killars otrygghet. Hur resonerar de kring trygghet i det offentliga rummet, oroar de sig för att utsättas för brott och vad får det $\mathrm{i}$ så fall för konsekvenser i deras vardag? Texten bygger på intervjuer gjorda med ungdomar och unga vuxna mellan 14-22 år som alla är uppvuxna och/eller spenderar mycket tid i vad som ofta beskrivs om några av Malmös mest otrygga områden. Vår forskning omfattar både killar och tjejer men i det här kapitlet har vi valt att fokusera på killarnas berättelser.

Att särskilt fokusera på unga killars upplevelser av otrygghet i relation till det offentliga rummet är intressant av flera skäl. Vi vet att unga män löper högre risk än andra grupper att utsättas för våldsbrott i det offentliga rummet (Brå 2019), samtidigt hamnar ofta killars upplevelser av problem och otrygghet i skuggan av tjejers och kvinnors (ofta) högre nivåer av oro och otrygghet. De högre nivåerna av otrygghet och oro bland kvinnor kan delvis förklaras av oron för sexuell utsatthet på offentlig plats (Mellgren \& Ivert, 2018). Det betyder dock inte att killar eller subgrupper av 
killar inte känner sig otrygga i det offentliga rummet eller att deras trygghetsupplevelse inte påverkas av fenomen, platser och personer i deras omgivning. Ytterligare ett skäl till att särskilt fokusera på unga killar är att de ofta pekas ut som en grupp som bidrar till andra människors otrygghet. Därför vill vi i det här kapitlet lyfta de upplevelser och erfarenheter som de unga killarna vi intervjuat delat med sig av, upplevelser och erfarenheter som tydligt visar att det offentliga rummets karaktär påverkar dem i lika stor utsträckning som de unga tjejer vi intervjuat. Till viss del identifierar killarna och tjejerna i vår studie samma fenomen som orsak till oro och otrygghet, och även konsekvenserna av oro överensstämmer till viss del mellan killarna och tjejerna. Samtidigt finns det också tydliga skillnader, diskussioner om sexuell utsatthet är frånvarande i intervjuerna med killarna, något som tjejerna däremot ofta uttrycker oro för och som făr konsekvenser för hur de rör sig och vad de gör i vardagen (för en mer utförlig jämförelse, se Egnell \& Ivert, 2019).

\section{BAKGRUND}

Otrygghet och oro att utsättas för brott har i forskning ofta diskuterats utifrån ett individuellt perspektiv (se t.ex. LaGrange \& Ferraro 1989 eller Warr 1984) och individuella egenskaper och erfarenheter har lyfts fram som förklaring till varför vissa individer är mer otrygga än andra. Samtidigt är det tydligt att trygghetsupplevelser varierar mellan olika platser och områden (se t.ex. Hale, 1996; Egnell \& Ivert 2016; Ivert, Torstensson Levander \& Mellgren 2016), och parallellt med de individuella förklaringsmodellerna har kontextuella faktorer lyfts fram som viktiga för att förstå varför de som bor eller vistas på en viss plats känner sig trygga eller otrygga. I forskningen lyfts ofta förekomst av ordningsstörningar (Skogan \& Maxfield 1981; Lewis \& Salem 1986) tillsammans med de boendes förmåga att upprätthålla gemensamma normer kring den offentliga miljön (Sampson 2012; Swatt m.fl. 2013; Brunton-Smith, Jackson \& Sutherland 2014) fram som viktiga förklaringsmodeller till varför trygghetsupplevelsen varierar mellan olika områden. Det finns också forskning som visar att kännedom om andras utsatthet kan ha större betydelse för den individuella trygghetsupplevelsen än egen utsatthet (Warr \& Ellison 2000; Hignite, Marshall and Naumann 2018). Det skulle kunna innebära att kunskap om andras utsatthet i närområdet påverkar i vilken utsträckning det upplevs som tryggt eller otryggt.

I den här texten är det just den omgivande kontexten och mer specifikt det offentliga rummet som är i fokus, men det är också viktigt att komma ihåg att det finns ett samspel mellan individ och kontext - individer påverkas på olika sätt av den omgivande miljön beroende på vilka de är och vilka erfarenheter de har.

Kunskapen kring otrygghet i det offentliga rummet bygger i huvudsak på vuxnas erfarenheter men ofta antas de erfarenheterna vara giltiga även för barn och ungdomar. Barns och ungdomars rörelsemönster skiljer sig från vuxnas, de använder sig 
av det offentliga rummet på andra sätt, och forskning visar att barn och ungdomar ofta tillbringar mer tid utomhus i bostadsområdet än vad vuxna gör (Leventhal m.fl. 2009). Därför är det sannolikt att barns och ungdomars uppfattningar av vad i bostadsområdet som påverkar deras trygghetsupplevelse skiljer sig från vuxnas uppfattningar (se t.ex. Spilsbury m.fl. 2012). Cops (2013) menar att när ungdomar förekommer i studier av otrygghet eller oro att utsättas för brott är det ofta som indikation på ordningsstörningar, och ett fenomen som skulle kunna bidra till otrygghet $i$ andra delar av befolkningen. Till exempel är det mer eller mindre standard att använda sig av fenomenet "ungdomar i grupp på offentlig plats som bråkar och stör" som en del av ett mått på sociala ordningsstörningar som förväntas påverka trygghetsupplevelsen.

Om forskning om hur ungdomars trygghetsupplevelse påverkas av de offentliga miljöer där de tillbringar sin tid är begränsad, så är studier som specifikt fokuserar på unga killars upplevelser trygghet i det offentliga rummet än mer sällsynta. Generellt sett verkar det som om pojkar oftare känner sig trygga än vad flickor gör och skillnaden är tydligast när det gäller platser som kan definieras som offentliga -utomhus i bostadsområdet på kvällen, ute på stan/på allmänplats, i kollektivtrafiken och när de besöker konserter, festivaler eller likande (Fridh m.fl. 2016; Blomdahl m.fl. 2017; Blomdahl \& Elofsson 2017; Robertsson, Begler and Sandahl 2017). Samtidigt är det viktigt att uppmärksamma att barn och ungdomar inte är någon homogengrupp och att såväl trygghetsupplevelsen generellt som de könsskillnader som går att identifiera kan skilja sig åt mellan olika åldersgrupper och det finns behov av åldersspecifika analyser. En brittisk studie (Goodey 1997) visade att flickor generellt uttryckte större oro än pojkar när de besvarade den klassiska frågan: "Har du varit orolig eller har någonting fått dig att känns dig nervös/obekväm ("on egde") utomhus?" När resultaten bryts ner och studeras för olika åldersgrupper så framträder dock en delvis annorlunda bild - vid 11 års ålder svarade $72 \%$ av pojkarna att de var oroliga utomhus medan motsvarande siffra för flickor var $57 \%$. Efter 12 års ålder gick dock flickorna om pojkarna i oro (a.a.).

Även om tidigare forskning visar på att det finns skillnader i vilken utsträckning tjejer och killar känner sig otrygga finns det också viktiga beröringspunkter mellan unga tjejer och unga killars upplevelser. Forskning om unga killars (o)trygghet på offentlig plats visar att de, precis som unga tjejer, upplever att unga killar i grupp är något som påverkar deras trygghetsupplevelse negativt (Johansson, Laflamme och Eliasson 2012; van der Burgt 2015; Egnell \& Ivert 2019). För unga killar verkar dock möten med unga killar i grupp främst vara kopplat till oro för att utsättas för våldsbrott och trakasserier, medan det för unga tjejer snarare handlar om oro för sexuellt våld och sexuella trakasserier (van der Burgt 2015; Johansson, Laflamme och Eliasson 2012).

\section{Riskminimerande strategier}

Tidigare forskning baserad på undersökningar bland vuxna visar att otrygghet kan medföra att individer vidtar vissa försiktighetsåtgärder såsom att låsa dörrar eller 
installera larm, och i vissa fall att individen anpassar och begränsar sin vardag (Heber 2007; Litzen 2006; Mellgren 2011).

Ungdomars upplevelser av otrygghet och/eller oro för brott kan påverka deras rörelse i det offentliga rummet, exempelvis hur de tar sig till och från skolan (Johansson, Hasselberg och Laflamme 2009). Istället för att ta offentliga färdmedel är en riskminimerande strategi att be om skjuts av föräldrar (a.a.). I vilken utsträckning barn för röra sig självständigt ute påverkas även av föräldrars riskuppfattning och bedömningar om hur farligt ett område är (Carver m.fl. 2010; Foster m.fl. 2014). Föräldrars nivåer av oro kan vara beroende av kön - det finns studier som visar att föräldrar i högre utsträckning oroar sig för sina döttrar än för sina söner (Drakulich 2015). Hur detta i sin tur påverkar barnens egna nivåer av oro och mobilitet finns det begränsad kunskap om. Det är ett viktigt område att undersöka då ungdomars självständiga rörelse i det offentliga rummet kan minska deras otrygghet och oro för brott (Cops 2013).

Brottsförebyggande rådets skolundersökning visar att det är vanligare att flickor ändrat eller anpassat sitt beteende på grund av oro att utsättas för brott än att pojkar gjort det (Brå, 2016) Den vanligaste beteendeförändringen bland både flickor och pojkar var att undvika vissa personer och platser. Cobbina, Miller och Brunson (2008) finner i sin forskning att både tjejer och killar har strategier för att minimera risken att utsättas för brott i det offentliga rummet, men att strategierna ser väldigt olika ut och är formade av skilda kulturella förväntningar på tjejer och killar. Bland killarna var den vanligaste strategin för att undvika att utsättas för brott att vara en del av grupp av fler andra killar, samtidigt är just dessa grupper av killar det som tjejerna upplever som det mest hotfulla i området. Bland tjejerna var den vanligaste strategin att undvika offentliga platser eller att hålla sig nära hemmet (a.a.).

Samtidigt som vissa riskminimerande strategier riskerar att öka otryggheten och leda till isolation så är försiktighetsåtgärder och oro "naturligt" och i viss utsträckning oundvikligt och kan också vara en viktig skyddsfaktor (Hale 1996; Jackson and Gray 2010).

\section{STUDIENS GENOMFÖRANDE}

Det material som ligger till grund för det här antologibidraget är som tidigare nämnts hämtat från en mer omfattande studie där vi intervjuat både unga tjejer och killar från olika två olika bostadsområden i Malmö (Egnell \& Ivert 2019). I det här kapitlet utgår vi från de unga killarnas berättelser och deras subjektiva upplevelser av sin närmiljö. Diskussionerna i intervjuerna utgår från begreppen risk, oro och otrygghet. Forskare skiljer ofta mellan uppfattningar om risker att utsättas för brott (kognition) och reaktioner på rädsla (affektion) (Ferraro och LaGrange 1987). Syftet med det är att visa på att otrygghet är ett komplicerat begrepp som kan behöver brytas ner i olika delar för att bättre förstå om det handlar om individers känslomässiga reaktioner på situationer 
eller miljöer eller snarare om en bedömning av situationens eller miljöns farlighet. Avgränsningen är viktig därför att individers enskilda bedömningar om risker för utsatthet inte nödvändigtvis sammanfaller med upplevelser av oro och rädsla för brott. Det är dock i princip omöjligt att helt skilja mellan de olika kategorierna och till viss del är de överlappande.

De 19 unga killar vi intervjuat i den här studien är mellan 14 och 22 år och alla bor, är uppvuxna eller tillbringar mycket tid i vad som ofta beskrivs om några av Malmös mest otrygga bostadsområden. Det är bostadsområden där det under en längre period funnit problem med otrygghet och kriminalitet. Det är också områden som återkommande varit föremål för både nationella och lokala satsningar med syfte att komma åt de lokala problemen och skapa trygga och attraktiva bostadsområden. Det är alltså områden där olika aktörer under flera års tid genomfört insatser som syftat till att öka tryggheten, inte sällan med fokus på det offentliga rummet.

De ungdomar som deltagit i studien har rekryterats via skolor, fritidsgårdar och föreningsliv i de aktuella områdena. Att deltagarna rekryterats via olika kanaler innebär förhoppningsvis att vi nått ungdomar med olika erfarenheter och olika sätt att använda sig av det offentliga rummet. Om vi endast gått via fritidsgårdar eller föreningsliv hade vi kanske främst nåt de ungdomar som rör sig mycket i området och har ett nätverk där vilket i sin tur kan innebära att de är mer trygga på offentlig plats. Genom att även rekrytera ungdomar via skolor är möjligheten att nå personer som annars eventuellt inte rör sig ute i området och/eller inte aktivt söker sig till föreningslivet.

Intervjuerna har genomförts i form av fokusgrupper och i något fall i form av enskild intervju. Fokusgruppsintervjuer medför en risk att enskilda erfarenheter hamnar i skymundan, och att en viss gemensam berättelse kommer att dominera samtalet. Detta skulle kunna innebära att vi antingen överskattar eller underskattar individers otrygghet, beroende på vilken som blir den gemensamma berättelsen. $\AA$ andra sidan kan fokusgruppsintervjuer ha fördelen av att de mer liknar ett vardagligt samtal och blir mindre styrda. Det kan bidra till att fler berättelser och erfarenheter framkommer än vid enskilda intervjuer (Bryman 2011; Liamputtong 2011). Eftersom deltagarna kan ifrågasätta varandras åsikter, erfarenheter och värderingar (vilket också skedde i våra fokusgruppsintervjuer) framträder dessutom motsättningar och motsägelser såväl mellan som inom individer (Finch \& Lewis 2003; Bryman 2011). Strukturen för intervjuerna var relativt öppen och utgick från öppna frågor kopplade till ett antal förutbestämda teman med utgångspunkten i specifika platser som deltagarna upplever som trygga eller otrygga. Utifrån dessa samtal fortsatte intervjuerna sedan med teman såsom oro att utsättas för brott, upplevelser av sammanhållning och social gemenskap i området samt ungdomarnas tankar kring åtgärder för att öka tryggheten på offentlig plats. Intervjuerna har även behandlat frågor som är relaterade till polisens roll, huruvida fler poliser ökar tryggheten och förtroendet för polisen.

Materialet består som redan beskrivits till stor det av fokusgrupper och det är därför rikt på diskussioner och motsägelser, men där finns övergripande mönster. Det är också viktigt att ha i åtanke att en stor del av materialet består av så kallade "kollektiva historier" och gruppnarrativ snarare än enskilda berättelser (Tiby 2009; Bryman 
2011). Fokus i analysen har legat på att identifiera teman och under underteman. En del av dessa teman var givna på förhand utifrån studiens teoretiska ansats och de frågeområden som intervjuerna tog sin utgångspunkt $\mathrm{i}$, men materialet innehåller även andra teman som uppstått i samtalet med ungdomarna och som ligger utanför de ursprungliga frågorna. Analysen är i huvudsak deskriptivt och tonvikten ligger på vad (erfarenheter, känslor, åsikter och händelser) som sägs, snarare än hur det sägs.

\section{Reflektioner om motstånd}

Studier som specifikt fokuserar på unga killars trygghetsupplevelse är ovanliga och kunskapen om hur gruppens trygghetsupplevelse påverkas av upplevelsen av fenomen i det offentliga rummet är begränsad. När unga killar figurerar i diskussioner om trygghet och otrygghet i det offentliga rummet är det ofta som ett fenomen som bidrar till andra individers otrygghet. Vår intention har därför varit att tillvarata och lyfta fram erfarenheter som sällan representeras vare sig i forskningen eller i den allmänna debatten om otrygghet. Eftersom vår studie genomförts i områden som i media eller av politiker ofta definieras som "problemområden", och detta är något som ungdomarna vi intervjuat är mycket medvetna om, har det varit viktigt att försöka lyfta ungdomarnas erfarenheter av området utan att låta det de säger färgas för mycket av bilden av området. Inledningsvis blev vi också ifrågasatta av några av ungdomarna om varför vi kom just till deras områden, och en del diskussioner uppstod om varför vi valt just dessa två områden. Initialt upplevde vi att det fanns ett motstånd och misstänksamhet mot våra intentioner med studien ifrån vissa av deltagarna. Vår upplevelse är dock att misstänksamheten avtog en bit in i intervjuerna, dels efter diskussioner om detta mellan deltagare men också i samband med att vi fick möjlighet att sätta vår studie i en större kontext. Vi upplevde också att det bland de flesta ungdomarna fanns en vilja att lyfta de problem och orsaker till otrygghet som de upplevde i sina bostadsområden och i Malmö i stort och diskutera dessa med varandra och med oss forskare.

Att en del av ungdomarna initialt var skeptiska till vår studie är egentligen inte förvånande. Det finns som sagt ett starkt medialt och politiskt fokus på de så kallade "problemområdena" och de problem som är förknippade med dessa, och det är en bild som de ungdomar vi intervjuat bara delvis kan känna igen sig i. När vi frågade efter positiva saker med deras bostadsområden var det inte svårt för deltagarna att nämna människor, platser och aktiviteter som de uppskattade. Vi tolkar det som att ungdomarna gärna pratar om problem, men att de upplever en brist på balans och att enbart det som är negativt lyfts fram i media och det politiska samtalet. Vi som forskare upplevde att vi blev representanter inte bara för forskarsamhället utan även för myndigheter i allmänhet. Och inte minst fick vi representera majoritetssamhället, vi betraktades framför allt i ett av områdena som "svennar", utomstående utan egna kunskaper och erfarenheter av de områden vi forskade om. Det framkom bland annat i form av frågor om var vi bodde, eller som hypotetiska berättelser om vad vi som "svenskar" och utomstående kunde få möta i dessa områden som de boende inte fick (exempel "tråkningar"). 
Mot bakgrund av detta har vi många gånger diskuterat huruvida vi är med och reproducerar onyanserade bilder genom vår forskning -vi riktar ännu en gång fokus på de problem som antas vara förknippade med vad som ofta benämns som utsatta områden. Vi anser dock att vi genom att intervjua ungdomar och lyfta röster som inte så ofta hörs från dessa områden faktiskt kan bidra till motsatsen. Vad som behövs är inte mindre forskning i dessa så kallade problemområden utan mer forskning som också lyfter det som är positivt i dessa områden. Samtidigt finns det ett behov av studier som fokuserar på vad som bidrar till trygghet och otrygghet $\mathrm{i}$ andra typer av områden för att på så sätt kunna bidra till teoriutveckling om orsaker till trygghet och otrygghet $\mathrm{i}$ det offentliga rummet.

\section{RESULTAT}

Resultatdelen är indelad i teman vars struktur i huvudsak följer den intervjuguide som använts i intervjuerna. Ett par av dessa teman har dock uppkommit induktivt, det vill säga producerats genom en läsning av materialet där vissa teman är återkommande trots att inga specifika frågor ställts kring just detta. Resultaten presenteras deskriptivt med citat som i de flesta fall syftar till att representera generella tendenser i materialet. Som läsare är det viktigt att ha med sig att de problem som beskrivs av de unga killarna inte nödvändigtvis ger upphov till känslor av otrygghet. Det är alltså teoretiskt av vikt att skilja mellan de problem som killarna upplever förekommer i området och de upplevelser av otrygghet de beskriver. Det är kontexten, eller det offentliga rummet/ offentlig plats som är i fokus i den här texten, men som vi nämnt tidigare är det viktigt att komma ihåg att det finns ett samspel mellan individ och kontext - individer påverkas på olika sätt av den omgivande miljön beroende på vilka de är och vilka erfarenheter de har.

Materialet från intervjuerna är omfattande men vi har i den här texten valt att fokusera på de teman som handlar om 1) vad som skapar otrygghet 2) begränsade beteenden i form av riskminimerande strategier och 3) uppfattningen om vilka personer som blir utsatta för brott.

\section{l." Det är alltid nån som ska försöka leka man"- Vad skapar otrygghet?}

Killarna beskriver att upplevelser av problem och i viss mån känslor av otrygghet är ganska tydligt kopplade specifika platser i deras områden, men även till grupperingar, konflikter och ryktesspridning som försiggår omkring dessa platser. Ofta är dessa platser tydligt avgränsade, såsom en park eller en del av en gata. Berättelsen om varför vissa platser skapar otrygghet är ofta förknippad med den höga närvaron av grupper 
av andra ungdomar och/eller gäng ${ }^{1}$, i del flesta fall bestående av unga killar, som frekvent vistas på dessa platser.

IP: Ifall ett gäng, alltså killar kommer mot dig och det är sent på kvällen. Det kan vara lite så.

Känslan av otrygghet som deltagaren ovan talar om beskrivs i flera av intervjuerna:

IP3: Men det är också det du vet om man är, som de sa på kvällen då, och sen det är, du går förbi ett litet gäng. Det är alltid nån som ska försöka leka man bland det gänget och ska gå och jävlas med nån annan som är utanför det gänget. Det är det man är mest rädd för. Annars ingenting.

IP5: De ser det som en chans som de vill plocka liksom. De kan råna, just nu. Det är kväll, och man har huva på, du kan inte se vem de är. Vissa försöker utnyttja chansen.

Ungdomarna beskriver även konflikter som finns mellan skolor och som har utgjort en källa till oro och problem för vissa av deltagarna, och i en av fokusgrupperna efterfrågas en högre närvaro av vuxna på skolområdet. Närvarande vuxna skulle generellt kunna öka tryggheten men även finnas där i egenskap av personer som kan ingripa i de fall där konflikter uppstår, enligt ungdomarna. Konflikter såsom dessa mellan skolor får konsekvenser för de unga killarnas möjlighet att använda de resurser som finns i området, till exempel används områdets fritidsgård främst av ungdomar från den ena skolan.

De båda områdena som ungdomarna rekryterades ifrån skiljer sig åt sett till geografisk placering i staden, folkmängd och karaktär. Detta ger upphov till olika typer av problem och förutsättningar för upplevelsen av trygghet. Det ena området upplevs av ungdomarna som anonymt och med få aktiviteter och lite människor i rörelse. Det andra området upplevs istället som tätt befolkat med mycket folk i rörelse, både dagtid och kvällstid (för en mer utförlig beskrivning och jämförelse av områdena, se Egnell \& Ivert 2019). Såväl öde allmänna platser såsom folkrika allmänna platser kan påverka känslan av otrygghet genom att de fungerar som tecken på ett områdes karaktär och de risker som eventuellt finns för att utsättas för brott (Skogan and Maxfield 1981; Warr 1990). Det är förstås inte enbart att det finns mycket eller lite människor på en plats som gör att den upplevs otrygg, utan även information om vilka dessa människor är och vad de upplevs göra. I våra intervjuer är det också tydligt att känslan av trygghet handlar om i vilken mån killarna känner gemenskap och stöd i sin omgivning, bland vänner och andra boende. En ung kille vi intervjuade uttryckte stor rädsla för att vistas ute i sitt område:

Intervjuare: Är det nånting som får dig att känna dig mer otrygg för att du är osäker på ifall nån skulle hjälpa dig ifall du råkade ut för nåt?

IP: Ja. för folk vill inte bli inblandade i saker. Alltid alltså. När om nånting händer med ett gäng eller nånting så säger folk ingenting för de känner sig inte trygga för det.

I För en utförlig diskussion om innebörden av begreppen gäng och grupperingar, se Egnell och lvert 2019. 
Han hade tidigare bevittnat en skjutning och upplevde en stark tystandskultur och en negativ social kontroll som innebar att det inte gick att lita på att människor ingrep vid händelse av brott på offentlig plats. I motsats till den här killens upplevelse är det många av de andra killarna som tvärtom kände en förhållandevis stark gemenskap i området, något som i sin tur kan bidra till ökad trygghet. Zuberi (2018) pekar på vikten av att det finns starka sociala band i områden med hög kriminalitet. De sociala banden till andra ungdomar gör att kriminalitet och ordningsstörningar inte får samma konsekvenser i form av otrygghet. Många av killarna känner sig trygga i sina områden just därför att de känner till ungdomar i området och de är själva kända - frasen "alla känner alla" förekommer relativt ofta, särskilt i relation till ett av områdena. Att vara känd av andra och att ha ett nätverk av vänner som skydd vid incidenter kan således utgöra en faktor för ökad trygghet, särskilt i områden med hög kriminalitet och mycket ordningsstörningar (Cobbina, Miller och Brunson 2008; Zuberi 2018).

De flesta av ungdomarna vi intervjuat känner sig trygga i sina områden och en del vistas regelbundet på de platser som av andra deltagare upplevs som stökiga eller oroliga. Att en del av killarna vistas på de platser som av andra beskrivs som otrygghetsskapande beror till viss del på åldersskillnader inom den grupp killar vi intervjuat, men sannolikt också på grund av vilka de umgås med samt när och hur de använder sig av det offentliga rummet. Även om de flesta oftast verkar känna sig trygga så finns det som påvisats dock indikationer på att de unga killarna ibland, i vissa situationer och på vissa platser, känner sig otrygga. Det framkommer tydligast i diskussioner om olika undvikande- och försvarsstrategier. Som vi ska se nedan är det inte nödvändigtvis så att ungdomarna själva ser dessa strategier som en konsekvens av otrygghet, men samtalen om sådana typer av strategier synliggör fenomen, personer och platser i områden som på olika sätt påverkar ungdomarnas rörelse och/eller beteenden i det offentliga rummet.

\section{2." Bara blanda inte in dig i nånting" - Riskminimerande strategier}

Det är som sagt få av deltagarna som uttrycker att det är otrygga i sina områden, endast ett fåtal menar att de är så pass oroliga för att själva bli utsatta för brott att det har stor påverkan på deras vardag. I intervjuerna framkommer det dock efter hand, när diskussionen mellan deltagarna blir mer öppna, att de flesta använder sig av någon typ av strategi för att hantera upplevda risker i områdena.

Grupper av unga killar i områdena är något som lyfts fram som otrygghetsskapande och förekomsten av sådana grupper påverkar märkbart deltagarna i våra intervjuer. Närvaron av dessa grupperingar gör att de killar vi har intervjuat i viss mån anpassar sin rörelse i det offentliga rummet genom att exempelvis undvika vissa platser helt eller vid vissa tidpunkter. I en av fokusgrupperna beskriver ungdomarna även att de tänker på sitt kroppsspråk och hur de för sig i mötet med andra killar på gatan. 
IP: Alltså typ om det är på kvällen och du går förbi en person och du kollar på han helt mycket, det är klart han kan bli arg på dig. Det är bara blanda inte in dig i nånting, bara gör ditt så händer ingenting.

De känslor som ungdomarna beskriver i den här passagen handlar om oron för att bli utsatt får våld eller hot genom att "provocera" andra killar på allmän plats. Liknande beteendeanpassningar finns även dokumenterade hos unga killar och vuxna män (se t.ex. Cobbina, Miller och Brunson 2008; Johansson, Laflamme och Eliasson 2012; May, Rader och Goodrum 2010). Det framträder att de unga killarna har en typ av kunskap inte enbart om sina områdens geografi och vem som "hänger" vart, men även hur de ska förhålla sig till andra unga killar, och inte minst hur de inte ska förhålla sig. Det som beskrivs är inte ett totalt undvikande utan en anpassning till en konfliktfylld miljö som de upplever i vissa situationer eller på vissa platser. Ungdomarna beskriver dessa anpassningar inte nödvändigtvis som uttryck för rädsla utan som en någorlunda naturlig del av vardagen, och som till viss del är omedvetna. Även om en beteendeförändring i sig kan vara en indikator på otrygghet (Hale 1996) så kan ett sådant förhållningssätt bidra till ökad trygghet genom att känslan av kontroll ökar hos de enskilda individerna (Carvalho \& Lewis, 2003). Ett fåtal av deltagarna uppger att de helst inte går ut alls på grund av grupperingar och gäng. En deltagare menar att han ändå hellre sitter hemma och spelar data-spel än beblandar sig med massa folk, medan en annan uppger att han är rädd för den hårda, och hotfulla stämningen som han upplever i delar av området. Ett totalt undvikande på grund av rädsla kan till skillnad från andra strategier leda till mer isolation och ökad otrygghet, samt ha andra negativa konsekvenser för individers livskvalitet (Hale 1996; Jackson \& Gray 2010).

Många av ungdomarna anser sig veta var "dåliga" miljöer och "dåliga" människor finns i deras områden och det är tydligt att de fattar rationella beslut utifrån den kunskapen för att undvika att utsätta sig för riskfyllda situationer och miljöer där de antingen kan bli utsatta för brott eller dras med i brott själva.

IP: Det är väl, det handlar också vilka man umgås med i ett område. Det kanske finns ett område där det är större risk av att man kan bli skadad, men det betyder också att det finns ett umgänge, lite större där som är anledningen till det. Så om man håller sig borta, man känner själv, detta är någonting som inte riktigt stämmer med det här umgänget. Så bara håll dig lite borta från det dåliga.

Att hålla sig borta från miljöer som ungdomarna uppfattar som kriminella eller stökiga miljöer är en viktig strategi för att undvika egen utsatthet. Det finns ett tydligt narrativ i fokusgrupperna kring vem som blir utsatt för brott, och det är inte vem som helst.

\section{3. "Det finns två olika världar." - Vilka blir utsatt för brott?}

Intervjuerna i det ena av området gjordes strax efter en uppmärksammad dödsskjutning av en 16-åring i just det området och samtalen kom i större utsträckning att 
handla om skjutningar och annat grovt våld än i fokusgrupperna i det andra området. Båda områdena har dock genom åren haft problem med grovt våld på offentlig plats (Polisen 2017), och varför eller vilka personer som riskerar att bli utsatta kom upp som ett frekvent tema. Det beskrivs av en ungdom på följande sätt:

IP3: Jag kan säga så här att, vi, det finns två olika världar. Den kriminella och den normala. Vi som är här vi lever i den här normala. Den kriminella, nästan alla känner varandra där och ingenting kommer hända dig om inte du har gjort nånting. Det kan jag lova, speciellt i [området]. Dör de, alltså om de ska gå ut och råna nån, slå nån, misshandla eller i värsta fall skjuta nån så är de hundra procent säkra på vem det är. Och när det görs och varför det görs. Så för min del jag kan gå ut kl. 1, 2, 3 på natten eller morgonen, det spelar ingen roll alltså, jag hade inte varit rädd för någon. För om inte, om inte du har gjort nånting, inget kommer hända dig. Däremot om du har gjort nånting, då ska du vara rädd om dig själv.

IP1: Alltså det enda man kan känna sig osäker, alltså det har hänt riktigt många skottlossningar men jag har fortfarande, jag känner mig trygg, alltså det, jag har inte med det att göra förstår du? Det har inte med mig att göra så varför ska jag känna mig osäker? För de siktar på en viss person alltså. Om de skjuter mot någons hus eller nån skottlossning $i$ ett område så de siktar på någon och han vet själv vem det är. Om du inte har problem med någon varför ska du känna dig sådär osäker?

Bland deltagarna finns en stark föreställning om vem som blir utsatt för grova brott och att den personen också förtjänar det därför att personen själv är kriminell eller umgås för nära den kriminella miljön. Det visar bland annat på den kunskap som de unga killarna besitter om de olika miljöerna och personerna som finns i deras områden, men det visar också på en medvetenhet om att de måste hitta sätt att navigera mellan dessa två "världar". Antagandet om att dåliga saker enbart drabbar den som förtjänar det - "har gjort något" - är troligtvis i sig själv trygghetsskapande och är ett narrativ som verkar delas av de flesta unga killar vi intervjuat. Framför allt ett av områdena präglas av en ung befolkning och hög trångboddhet, vilket gör att ungdomarna spenderar mycket av sin tid utomhus på offentlig plats. Det kan bidra till en ökad risk för konflikter och exponering av kriminalitet (Polisen 2017). Ungdomarna är väl medvetna om dessa förutsättningar och betonar själva sin kunskap om områdets karaktär och vikten av att välja sitt umgänge väl för att inte utsättas för våld. Sharkey (2006) benämner denna kunskap som street efficacy, det vill säga en "upplevd förmåga att undvika våldsamma konfrontationer och vara trygg i sitt eget område" (a.a.:827, vår översättning). Utifrån delar av en påtvingad, större miljö skapar ungdomarna sina egna minde kontexter som upplevs som tryggare och minskar risken för utsatthet (a.a.). Ett annat begrepp som förekommer i litteraturen och som tangerar street efficacy är så kallade kognitiva kartor (Höglhammer m.fl. 2018). Dessa utgörs av tidigare erfarenheter av området och används för navigation i ett områdes sociala och fysiska miljö och som underlag för riskbedömning. Kunskap om och erfarenheter av sitt närområde antas vara viktigt för känslan av trygghet (Ceccato \& Bamzar 
2016) och den specifika kunskapen som de unga killarna ger uttryck för i intervjuerna bidrar sannolikt till att de känner sig mer trygga. Denna kunskap är troligtvis högre än bland vuxna som bor i samma område och skulle kunna vara en förklaring till att ungdomarna inte ser på området på riktigt samma sätt som de vuxna.

\section{AVSLUTANDE DISKUSSION}

Genomgående i resultaten från den här studien är att de flesta av killarna säger att de är trygga i sina områden. I den mån de känner sig otrygga är det ofta kopplat till samma fenomen som vuxna eller unga tjejer pekar ut som orsak till otrygghet nämligen förekomsten av andra unga killar i grupp i det offentliga rummet. Detta resultat bekräftar vad som finns dokumenterat i tidigare forskning (Johansson, Laflamme och Eliasson 2012; van der Burgt 2015). Det framkommer som tydligast när vi frågar om det finns något som om killarna undviker i sina områden och hur de hanterar de risker de ser i det offentliga rummet. Killarnas berättelser visar att de utvecklar så kallade riskminimerande strategier för att hantera situationer i det offentliga rummet som de upplever som riskfyllda eller otrygga. Dessa strategier är bland annat ett resultat av tidigare erfarenheter som utgör så kallade kognitiva kartor (Höglhammer m.fl. 2018). Dessa kartor används för nödvändig navigation och riskbedömning i ett område. Undvikandestrategier - det vill säga att undvika vissa områden, mikroplatser eller personer är vanliga såväl hos unga tjejer och unga killar (Cobbina, Miller och Brunson 2008; Johansson, Laflamme och Eliasson 2012; Höglhammer m.fl. 2018). En del av de killar vi intervjuat undviker helt vissa platser i sina områden, men vanligt förekommande är också att hantera risker på plats, dvs. att röra sig i det offentliga rummet men att ha vissa strategier för att undvika till exempelvis att konflikter eller tjafs uppstår. Det kan handla om att vara uppmärksam på om det är andra killar i grupp runtomkring, att undvika vissa umgängen på en gemensam yta eller att inte möta blickar på ett sätt som kan tolkas som en provokation Den här typen av beteendeanpassning till en potentiellt hotfull miljö kommer från kunskap om området och de personer som befinner sig där, något som ibland kallas för street efficacy (Sharkey, 2006). Troligtvis är vissa av anpassningarna som beskrivs normaliserade men även rimliga, och behöver i sig inte per automatik leda till mer otrygghet. Tvärtom kan det vara en viktig skyddsfaktor och minska otryggheten (Hale 1996; Jackson and Gray 2010). Att vara vaksam på och undvika vissa umgängen berör ett annat centralt resultat för studien, nämligen den starka föreställningen hos en del av killarna om att utsatthet för allvarlig våldsbrottslighet såsom misshandel och skjutningar inte drabbar vem som helst. De menar att det drabbar de killar som umgås med fel personer, och både de personer som begår våldshandlingar och de som blir utsatta vet om att detta kommer att ske. På så sätt drabbar det ingen "oskyldig". Killarna är medvetna om nödvändigheten i att navigera mellan dessa två världar som de exponeras för och de 
skapar sina egna trygga rum utifrån erfarenhet och kunskap - de utvecklar en form av street efficacy (Sharkey 2006). De flesta ungdomar utvecklar och utövar sannolikt någon typ av street efficacy för att hantera de situationer de möter i sin vardag. Samtidigt skiljer sig de miljöer ungdomar exponeras för åt mellan olika delar av Malmö och ungdomar från vissa områden exponeras i högre utsträckning för riskfyllda och kriminella miljöer.

\section{REFERENSER}

Blomdahl, U. \& Elofsson, S. (2017). Jämställd och jämlik! Hälsa och offentligt resursutnyttjande på fritidsområdet bland barn och ungdomar. Stockholm: Stockholms universitet.

Blomdahl, U., Elofsson, S., Bergmark, K. \& Lengheden, L. (2017). Ung livsstil Malmö. En studie av ungdomar i högstadiet. Stockholm: Stockholms universitet.

Brottsförebyggande rådet, Brå (2016). Skolundersökningen om brott 2015. Om utsatthet och delaktighet $i$ brott. (Rapport 2016: 21). Stockholm: Brottsförebyggande rådet.

Brottsförebyggande rådet, Brå (2019). Nationella trygghetsundersökningen 2018. Om utsatthet, otrygghet och förtroende. (Rapport 2019:1). Stockholm: Brottsförebyggande rådet.

Brunton-Smith, I., Jackson, J. \& Sutherland, A. (2014). Bridging Structure and Perception. On the Neighborhood Ecology of Beliefs and Worries About Violent Crimes. British Journal of Criminology, 54, 503-526.

Bryman, A. (2011). Social research methods, 4th ed., Oxford: Oxford University press.

Carvalho, I. \& Lewis, D.A. (2003) Beyond Community: Reactions to Crime and Disorder Among Inner-City Residents. Criminology, 41(3), s. 779-812.

Carver A, Timperio A, Hesketh K \& Crawford D. (2010) Are children and adolescents less active if parents restrict their physical activity and active transport due to perceived risk? Social science \& medicine, 70(11), s. 1799-805

Ceccato, V. \& Bamzar, R. (2016) Elderly Victimization and Fear of Crime in Public Spaces. International Criminal Justice Review, 26(2), s. 115-133

Cobbina, JE, Miller, J. \& Brunson, RK. (2008) Gender, Neighborhood Danger, and Risk-Avoidance Strategies among African-American Youths. Criminology, 46(3), s. 501-538

Cops, D. (2013). The role of autonomous mobility in public space on fear of crime among adolescents. Journal of Youth Studies, 16(8), 1105-1122. 
Drakulich, K.M. (2015) Concerns for Self or Family? Sources of and Response to Altruistic Fear. Journal of Interpersonal Violence, 30(7), s. 1168-1207.

Egnell, S. \& Ivert, A-K. (2016). Flera nyanser av trygghet. (FoU-rapport 2016:2). Malmö: Malmö högskola.

Egnell, S. \& Ivert, A-K. (2019).

Ferraro, K.F. \& LaGrange, R. (1987) The Measurement of Fear of Crime. Sociological Inquiry, 57(1), s. 70-97.

Finch, H. \& Lewis, J. (2003). “Focus groups", i J. Ritchie \& J. Lewis (red.) Qualitative research practice. A Guide for Social Science Students and Researchers, s. 170-198. London: Sage Publication.

Foster, S., Villanueva, K., Wood, L., Christian, H., \& Giles-Corti, B. (2014). The impact of parents' fear of strangers and perceptions of informal social control on children's independent mobility. Health \& place, 26, 60-68.

Fridh, M., Grahn, M., Lindström, M. \& Modén, B. (2016). Folkhälsorapport Barn och Unga i Skåne 2016 - en undersökning om barn och ungdomars livsvillkor, levnadsvanor och hälsa, Skåne: Region Skåne.

Goodey, J. (1997) Boys Don't Cry. Masculinities, Fear of Crime and Fearlessness. British Journal of Criminology, 37(3), s. 401-418

Hale, C. (1996) Fear of Crime: a Review of the Litterature. International Review of Victimology, 4, s. 79-150.

Heber, A. (2007) Var rädd om dig! Rädsla för brott enligt forskning, intervjupersoner och dagspress. (Akademisk avhandling) Stockholm: Stockholms Universitet.

Hignite, LR, Marshall, S. \& Naumann, L. (2018) The Ivory Tower Meets the Inner City: Student Protective and Avoidance Behaviors on an Urban University Campus. College Student Journal, 52 (1), s. 118-138

Höglhammer, A, Muhar, A, Stokowski, P, Schauppenlehner, T. \& Eder, R. (2018) Factors affecting adolescents' use of urban public spaces in their leisure time: an exploratory study from the city of Vienna. The International Journal of Justice and Sustainability, 23(8), s. 814-829

Ivert, A. K., Levander, M. T., \& Mellgren, C. (2016). Den ojämlika otryggheten-Stabilitet och förändring i bostadsområden över tid. Socialvetenskaplig tidskrift, 22(3-4).

Jackson, J. \& Gray, E. (2010) Functional Fear and Public Insecurities About Crime. British Journal of Criminology, 50, s. 1-22

Johansson, K., Hasselberg, M., \& Laflamme, L. (2009). Exploring the neighbourhood: a web-based surveyon the prevalence and determinants of fear among young adolescent boys and girls, International Journal of Adolescent Medicine and Health, 21(3), 347-359.

Johansson, K., Laflamme, L. \& Eliasson, M. (2012). Adolescents' Perceived Safety and Security in Public Space-A Swedish Focus Group Study with a Gender 
Perspective. Young, 20(1), s. 69-88.

LaGrange, R. L., \& Ferraro, K. F. (1989). Assessing age and gender differences in perceived risk and fear of crime. Criminology, 27, 697-719.

Leventhal, T., Dupéré, V. and Brooks-Gunn, J. (2009). Neighborhood Influences on Adolescent Development. Handbook of Adolescent Psychology. 2: III:12.

Lewis, D.A. \& Salem, G. (1986). Fear of Crime. Incivility and the Production of a Social Problem. New Jersey: Transaction, Inc.

Liamputtong, P. (2011). Focus Group Methodology: Principles and Practice, London: Sage Publications Ltd.

Litzen, S. (2006) Oro för brott i urban miljö. Trygghetsundersökningar med anknytning till Stockholm. (Rapport 2006:1). Stockholm: Kriminologiska institutionen.

Mellgren, C. (2011). What's neighbourhood got to do with it? The influence of neighbourhood context on crime and reactions to crime. (Akademisk avhandling) Malmö: Malmö Högskola.

Mellgren, C. \& Ivert, A-K. (2018) Is Women's Fear of Crime Fear of Sexual Assault? A Test of the Shadow of Sexual Assault Hypothesis in a Sample of Swedish University Students. Violence Aainst Women, 25(5), s. 511-527

Polisen, (2017). Utsatta områden - Social ordning, kriminell struktur och utmaningar för polisen. Stockholm: Nationella operativa avdelningen.

Robertsson, H., Begler, E. \& Sandahl, J. (2017). Stockholmsenkäten. Årsrapport 2016. Stockholm: Socialförvaltningen.

Sampson, R.J. (2012). Great American city: Chicago and the enduring neighborhood effect. London: The University of Chicago Press

Skarkey, PT. (2006) Navigating Dangerous Streets: The Sources and Consequences of Street Efficacy. American Sociological Review, 71, s. 826-846

Skogan, WG. \& Maxfield. MG. (1981). Coping With Crime: Individual and Neighborhood Reactions, Newbury Park, CA: Sage Publications.

Spilsbury, J. C., Korbin, J. E., Coulton, C. E. (2012). "Subjective" and "objective" views of neighborhood danger and well-being: The importance of multiple perspectives and mixed methods. Child Indicators Research, 5, 469-482.

Swatt, M.L., Varano, S.P., Uchida, C.D. \& Solomon, S.E. (2013). Fear of crime, incivilities, and collective efficacy in four Miami neighborhoods, Journal of Criminal Justice, 41, 1-11.

Tiby, E. (2009). Stranger-Danger or Fear of the Near? Accounts on Fear of Sexual Abuse, Journal of Scandinavian Studies in Criminology and Crime Prevention, 10(2), s144-160.

van der Burgt, D. (2015) Spatial avoidance or spatial confidence? Young people's agency in the active negotiation of risk and safety in public space. Children's Geographies, 13(2), s. 181-195 
Warr, M. (1984). Fear of victimization: Why are women and the elderly more afraid? Social Science Quarterly, 65, 681-702.

Warr, M. \&Ellison, CG. (2000) Rethinking Social Reactions to Crime: Personal and Altruistic Fear in Family Households. American Journal of Sociology, 106(3), s. 551-578

Zuberi, A. (2018) Feeling Safe in a Dangerous Place: Exploring the Neighborhood Safety Perceptions of Low-Income African American Youth. Journal of Adolescent Research, 33(1), s. 90-116 


\section{STUNDA: Mobilapplikationen som verktyg för ökad kunskap om (o)trygghet och oro för brott bland unga vuxna i Malmö}

Karl Kronkvist \& Alexander Engström

"[...] både antal anmälda brott per invånare och Malmöbornas enkätsvar till polisen talar ett tydligt språk - risken för 'vanliga Malmöbor' att utsättas för brott sjunker. Ändå indikerar polisens trygghetsundersökning att otryggheten ökar."

Sydsvenskan 29 augusti 2018

Även om otrygghet och brottslighet är sammankopplade måste de betraktas som två olika sociala problem. Otrygghetens subjektiva karaktär innebär att det alltid finns utrymme för olika tolkningar och upplevelser bland olika individer. Att forska om otrygghet är därför inte helt enkelt. Samtidigt är det viktigt att studera just trygghet och otrygghet för att utveckla insatser som gör att fler känner sig trygga. I detta kapitel diskuterar vi de utmaningar som finns när det kommer till forskning om otrygghet men ger även konkreta förslag på hur vi genom utvecklad trygghetsforskning kan öka kunskapen om (o)trygghet bland unga i Malmö.

\section{(O)TRYGGHET OCH DESS KONSEKVENSER}

Trygghet är ett återkommande inslag i Malmökommissionens slutrapport (Malmö stad, 2013) vilket signalerar att detta är en central aspekt av Malmöbornas levnadsvillkor. Samtidigt är det viktigt att poängtera att trygghetsbegreppet kan relateras till många olika områden, till exempel ekonomi och hälsa. Inom kriminologisk forskning ligger dock fokus företrädesvis på brottslighet och andra liknande sociala problem som kan kopplas till upplevelser av trygghet och otrygghet. Studier med särskilt fokus på Malmö visar att tryggheten varierar dels beroende på var du bor i staden och dels beroende av vem du är (se bl.a. Ivert, Torstensson Levander \& Mellgren, 2015; Lindström, Merlo \& Östergren, 2003). Även äldres trygghetsupplevelser och bostadsområdets betydelse för den upplevda tryggheten har lyfts fram i lokala studier (Mellgren, 2011; Stjernborg, 2017). 
Överlag visar kriminologisk forskning att otrygghet är kopplat till en rad negativa konsekvenser för den enskilde individen (Stafford, Chandola, \& Marmot, 2007) men också för samhället i stort genom bland annat minskad mellanmänsklig tillit och minskad kontroll över de gemensamma rummen (Wilson \& Kelling, 1982; Skogan, 1986; Hale, 1996). Den som inte vågar röra sig fritt i staden eller i sitt bostadsområde begränsas i sin vardag och kan därmed inte bidra till den kollektiva gemenskap som kan skapa trygghet och social hållbarhet. Det är därför inte förvånande att kriminalpolitiken förutom att minska brottsligheten även har som mål att öka tryggheten (Regeringen, 2018). Trygghetsfrågornas centrala betydelse i dagens politik kommer även till uttryck i de politiska valrörelserna där partierna i varierande grad kopplar begreppet till såväl välfärd som rättsväsendet (Hermansson, 2018).

Även om otrygghet ofta lyfts fram som ett samhällsproblem inom såväl den politiska, mediala som akademiska debatten, finns det ingen universell definition av begreppet. Inom den kriminologiska trygghetsforskningen återfinns en mängd olika definitioner och indikatorer som ryms under paraplybegreppet otrygghet (eng. fear of crime) (se t.ex. Ferraro \& LaGrange, 1987; Ferraro, 1995; Farrall, Bannister, Ditton, \& Gilchrist, 1997; Hough, 2004). Som en logisk följd av detta finns därmed en rad olika utmaningar i hur trygghetsupplevelser ska eller bör undersökas och mätas (jmf. Heber, 2008).

Det kanske mest konventionella sättet för att mäta trygghet är genom undersökningar som vanligtvis genomförs en gång per år genom en post- eller webbenkät riktad till ett slumpmässigt urval av studiepopulationen. Brottsförebyggande rådets årliga Nationella trygghetsundersökning (NTU; se Brå, 2019) är ett sådant välkänt exempel, men undersökningar sker även på lokal nivå. I Malmö genomförs till exempel Malmö områdesundersökning (MOMS; se Ivert, Chrysoulakis, Kronkvist \& Torstensson Levander m.fl., 2013) och Polisens årliga trygghetsmätning i region Syd. I denna typ av studier undersöks vanligtvis flera olika perspektiv på otrygghet genom att ställa frågor om oro för brottsligheten i samhället på ett generellt plan, oro för att själv utsättas för brott (t.ex. inbrott, misshandel och sexuella övergrepp), oro för andra personers trygghet (s.k. altruistisk otrygghet) samt konsekvenser av otrygghet (t.ex. att välja annat färdsätt till följd av otrygghet).

Resultaten från dessa undersökningar visar på ganska stabila mönster i trygghet och att otrygghet i relation till kriminalitet, precis som för den hälsorelaterade och ekonomiska tryggheten, är ojämnt fördelad i befolkningen. I senaste NTU går det till exempel att urskilja att kvinnor oftare än män, särskilt bland yngre, upplever olika former av otrygghet (Brå, 2019). Exempelvis uppger nästan hälften av kvinnorna i åldern 20-24 år att de är otrygga när de går ut ensamma en sen kväll i sitt bostadsområde. Ungefär en lika stor andel uppger också att de under det senaste året har valt att ta en annan väg eller annat färdsätt på grund av otrygghet.

Dessa resultat visar att otryggheten bland ungdomar och yngre vuxna, och yngre kvinnors upplevelser i synnerhet, måste tas på allvar. Samtidigt finns det uppenbara begränsningar med den här typen av konventionella tillvägagångssätt för att undersöka trygghetsupplevelser. Begränsningarna kretsar kring de grundläggande metodologiska frågorna: "vad är det egentligen vi mäter?" och "hur mäter vi det?" 


\section{BEGRÄNSNINGAR I KONVENTIONELLA TRYGGHETSUNDERSÖKNINGAR}

I konventionella trygghetsundersökningar saknas ofta en fördjupad bild av de ungas perspektiv på otrygghet. Bristen på kunskap om ungas situation riskerar leda till att trygghetsskapande insatser i huvudsak utgår från kunskap om vissa grupper av individer (t.ex. äldre) som i större utsträckning deltar i konventionella trygghetsundersökningar, och i mindre utsträckning på kunskap om grupper som generellt sett är underrepresenterade i denna typ av studier (t.ex. unga).

Ett annat problem är att konventionella trygghetsundersökningar vanligtvis genomförs på årsbasis med en tvärsnittsdesign. Exempelvis tillfrågas respondenter om det har hänt under det senaste året att de valt att ta en annan väg eller ett annat färdsätt på grund av oro för att utsättas för brott, med fasta svarsalternativ från mycket ofta till aldrig. Även om denna fråga kan ge en viktig indikation på en generell oro förutsätter den att studiedeltagarna kan sammanfatta sina upplevelser i relation till det gångna året. Detta medför problem med teleskopeffekter (svårigheter att minnas när och om en specifik händelse inträffade inom en specifik tidsperiod) och aggregeringsbias (svårigheter att uppskatta antalet gånger en händelse inträffat över en specifik tidsperiod). Dessutom innebär tvärsnittsdesigner även begränsningar i att undersöka individuella mönster av otrygghet över tid. Detta är ett problem eftersom ny forskning indikerar att trygghetsupplevelser är ett dynamiskt fenomen som varierar i stor utsträckning, bland annat i relation till de olika sammanhang som individer kommer i kontakt med i sin vardag (Chataway, Hart, Coomber, \& Bond, 2017; Solymosi, Bowers \& Fujiyama, 2015).

Detta leder in på det tredje tillkortakommandet med konventionella trygghetsmätningar, nämligen vilka situationer som undersöks. En återkommande fråga i NTU (och MOMS) är att respondenten ombeds ta ställning till hur trygg eller otrygg hen känner sig i att gå ut, ensam, sent en kväll, i sitt eget bostadsområde. Här undersöks alltså otrygghet som en specifik och avgränsad händelse. Detta kan liknas vid ett situationellt perspektiv på otrygghet (se Engström \& Kronkvist, 2018), där den grundläggande idén består av att olika utfall (t.ex. beteenden, reaktioner, känslor) är resultatet av en interaktion mellan individen och den avgränsade del av miljön i vilken individen befinner sig (Mischel, 2004). Mer konkret kan en situation definieras utifrån var den äger rum (både geografiskt och social kontext), vad som händer, och vilka andra som är närvarande (Pervin, 1978). Med tanke på hur dessa faktorer kan variera över till exempel en dag, betyder detta alltså att det finns hundratals olika typer av situationer som människor möter i sin vardag. Även om att "vara ute och gå, ensam, sent en kväll i sitt eget bostadsområde" kan betraktas som en viktig situation, är frågan om denna situation verkligen kan ses som representativ för individers vardag och därmed vara ett lämpligt generellt mått på otrygghet. 


\section{ALTERNATIVTILL KONVENTIONELLATRYGGHETS- UNDERSÖKNINGAR}

För att åtgärda dessa tillkortakommanden krävs nya undersökningsinstrument men även nya metodologiska ansatser. Användandet av mobilapplikationer i trygghetsforskning (se Solymosi m.fl., 2015) och så kallad Experience Sampling Method (ESM; Larson \& Csikszentmihalyi, 1983) ger goda möjligheter att fördjupa kunskapen om trygghetsupplevelser över tid och i olika situationer. Detta ska ses som ett komplement till den kunskap som genereras genom mer konventionella trygghetsundersökningar men har några viktiga fördelar som ger möjligheter att öka kunskapen om ungas trygghetsupplevelser:

- I stort sett alla unga använder internettjänster i mobiltelefonen varje dag (Davidsson, Palm, \& Melin Mandre, 2018). Därför är en mobilapplikation ett verktyg som når ut till unga personer i deras vardagsliv.

- Att integrera en trygghetsundersökning (t.ex. enkäter) i en mobilapplikation gör det möjligt att följa samma individer över tid, på såväl längre som kortare sikt. Detta möjliggör även att frångå tvärsnittsdesignen genom att applicera en (mini)longitudinell forskningsdesign, alltså med flera olika mättillfällen för deltagarna. Genom denna forskningsdesign går det även att vid varje svarstillfälle ställa frågor med kortare referensperioder (t.ex. det senaste dygnet).

- Med hjälp av en mobilapplikation går det även att undersöka (o)trygga situationer i nära anslutning till när de inträffar (grundtanken i ESM) vilket inte är möjligt i traditionella enkätundersökningar.

Den sista punkten är särskilt aktuell eftersom det inom kriminologisk forskning på senare år har växt fram en särskild inriktning mot att undersöka situationer mer specifikt. Som exempel kan nämnas att forskare med hjälp av en dagboksmetod har studerat situationella aspekter av brottsdeltagande (se bl.a. Bernasco, Ruiter, Bruinsma, Pauwels, \& Weerman, 2013; Wikström, Oberwittler, Treiber, \& Hardie, 2012) och utsatthet för brott (Averdijk \& Bernasco, 2015). Dessa studier bygger på att brottsdeltagande och utsatthet för brott har undersökts i relation till den faktiska brottshändelsen, alltså i den situation där händelsen inträffade. Inom trygghetsforskningen är detta angreppssätt ännu outvecklat eftersom otrygghet inte har betraktats som en händelse. Det vore fel att påstå att all otrygghet kan kopplas till en specifik händelse och därmed rymmas i en situationell förklaringsmodell men studier har visat att det finns anledning att betrakta vissa upplevelser av otrygghet som situationella företeelser (Chataway m.fl., 2017; Solymosi m.fl., 2015).

I en av dessa studier (Solymosi m.fl., 2015) ombads studiedeltagarna att genom en mobilapplikation besvara ett antal frågor relaterade till trygghet vid slumpmässiga tillfällen under en dag. Resultaten visade att olika tidpunkter, olika platser och olika situationella omständigheter var kopplade till variationer i upplevelser av otrygghet. Även om studien var av pilotkaraktär visar den att trygghet kan undersökas som en 
händelse, avgränsad i tid och rum i en viss typ av situation. Eftersom individer upplever en oöverskådlig mängd och olika typer av situationer under till exempel ett år, saknar årliga retrospektiva enkäter möjligheten att undersöka trygghet och otrygghet i alla de olika situationer där de upplevs. Ett situationellt perspektiv på otrygghet kräver därför ett instrument som faktiskt mäter de olika situationer som individer upplever, snarare än att konstruera hypotetiska idealsituationer som kanske aldrig har upplevts av de personer som svarar på en enkät.

\section{STUNDA: EN PILOTSTUDIE OM (O)TRYGGHET BLAND UNGA I MALMÖ}

Under hösten 2018 genomfördes en pilotstudie inom ramen för forskningsprojektet STUNDA: Att undersöka upplevelser av situationell otrygghet genom smarta telefoner bland unga vuxna i Malmö. Det övergripande syftet med studien var att undersöka om mobilapplikationen STUNDA (Situationell TrygghetsUNDersökningsApplikation) som datainsamlingsinstrument kunde öka kunskapen om (o)trygghetens variationer över tid och rum bland unga vuxna. Ett viktigt steg i att utveckla nya metoder är att testa i liten skala för att sedan, vid framgång, utveckla konceptet och implementera det i större skala (Sullivan \& McGloin, 2014). Projektet fokuserade därför på just det småskaliga pilotperspektivet och tog sin utgångspunkt $\mathrm{i}$ att undersöka om det föreslagna studiekonceptet är en väg framåt för ökad kunskap om trygghet och otrygghet. Studiens genomförande utformades som ett svar på de tre problemen ovan genom att deltagarna bestod av unga personer som svarade på enkäter vid flera tillfällen i relation till specifika situationer i deras vardag.

Både innehållet och utformningen av STUNDA är dels inspirerade av den mobilapplikation som Solymosi m.fl. (2015) använde i sin studie och dels av dagboksmetoden som Wikström m.fl. (2012) använde sig av. När deltagarna laddat ned STUNDA till sin mobiltelefon besvarade de en startenkät med olika frågor om bland annat demografi, livsstil och trygghet. Syftet med startenkäten var att samla information som kan kopplas till individuella skillnader i otrygghet (t.ex. ålder, kön, livsstil och tidigare utsatthet för brott). Efter att startenkäten besvarats fick deltagarna tillgång till STUNDA:s andra funktioner som bestod av snabbenkäten och den dagliga enkäten.

Snabbenkäten besvarade deltagarna inom 20 minuter efter att de mottagit en notifikation ( 3 ggr./dag) och användes för att slumpmässigt undersöka trygghet i relation till de olika situationer som deltagarna befann sig i vid tidpunkten för notifikationen. Förutom frågor om trygghet innehöll snabbenkäten frågor om vilken typ av plats som personen befann sig på (t.ex. hemma, i skolan, på jobbet), vilken aktivitet som pågick (t.ex. pluggade, shoppade, tränade) och vilka andra personer som var närvarande (t.ex. partner, vänner, familj). Geografisk position och klockslag sparades automatiskt 
av applikationen. Den dagliga enkäten innehöll frågor om trygghet under de senaste 24 timmarna och gav också möjlighet för deltagarna att koppla otrygga upplevelser under dagen till specifika otrygga situationer utifrån samma frågor som ställdes i snabbenkäten. Varje kväll fick deltagarna en notifikation som påminde dem om att fylla i den dagliga enkäten.

\section{URVAL OCH DELTAGARBETEENDEN}

Eftersom STUNDA bygger på ett relativt obeprövat tillvägagångssätt är en första naturlig frågeställning om det över huvud taget är möjligt samla relevant information om trygghetsupplevelser i olika situationer genom den aktuella studiedesignen. Studenter vid Malmö universitet rekryterades till studien utifrån ett bekvämlighetsurval genom information om studien i både klassrum och montrar i universitets lokaler. Totalt visade 933 studenter intresse av att delta i studien genom att ta emot inloggningsuppgifter till STUNDA. Av dessa valde 191 personer (20,5\%) att fylla i startenkäten vilket innebar att de inkluderades i studiens slutliga urval. En majoritet av deltagarna (70,7\%) bestod av kvinnor och den genomsnittliga åldern bland deltagarna var 23,6år. Nästan nio av tio deltagare var i viss eller stor utsträckning oroliga över brottsligheten i samhället och drygt hälften trodde att brottsligheten i Malmö har ökat de senaste tre åren.

Totalt besvarades ca 1300 snabbenkäter fördelade på de 131 (68,5\%) individer som valde att använda denna funktion. Antalet deltagare som besvarade minst en daglig enkät var högre i och med att 163 deltagare (85,3\%) besvarade knappt 950 dagliga enkäter. Det är svårt att säkert veta varför inte alla deltagare besvarade en snabbenkät eller en daglig enkät. En tänkbar anledning är att det innebär en viss börda att inte enbart fylla i startenkäten utan att även fortsätta fylla i såväl snabbenkäter som dagliga enkäter, särskilt med tanke på avsaknaden av incitament för deltagandet (för en utförlig diskussion om bl.a. svarsfrekvenser vid smartphonebaserade ESM-studier, se van Berkel, Ferreira, \& Kostakos, 2018). Samtidigt har ändå de flesta besvarat åtminstone en snabbenkät och en daglig enkät vilket visar att det definitivt finns en majoritet som kan tänka sig att bidra med information vid upprepade tillfällen.

Ett intressant fenomen i materialet är att det verkar finnas olika deltagarbeteenden bland olika individer. I förhållande till snabbenkäten kan det konstateras att endast 10 procent av samtliga deltagare stod för drygt hälften (54\%) av samtliga inrapporterade snabbenkäter. Denna grupp benämns här som dedikerade deltagare. Jämfört med den genomsnittliga deltagaren som besvarade sju stycken snabbenkäter, besvarade de dedikerade deltagarna istället i snitt 36 snabbenkäter. Likaså deltog de dedikerade deltagarna i studien under i genomsnitt 19 dagar jämfört med fyra dagar för samtliga deltagare. Som framgår av figur 1 besvarade 
dedikerade deltagare i genomsnitt mellan en och två snabbenkäter varje dag under (minst) fjorton dagaroch detta antalvar förhållandeviskonstantunderdenna tidsperiod.

3

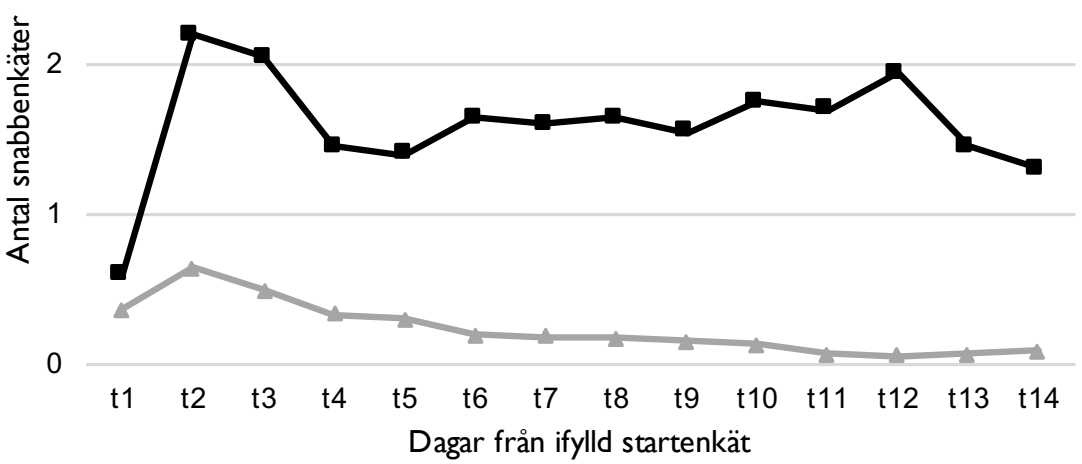

-Dedikerade deltagare $(\mathrm{N}=20)$

$\simeq$ Övriga deltagare $(\mathrm{N}=|7|)$

Figur 1. Skillnader i antal besvarade snabbenkäter per dag (max 3) mellan dedikerade deltagare $(N=20)$ och övriga deltagare $(N=171)$.

Gruppen dedikerade deltagare går även att identifiera i förhållande till den dagliga enkäten. Omkring 20 procent av samtliga deltagare stod för drygt hälften (56\%) av de dagliga enkäterna och denna grupp besvarade i genomsnitt 16 dagliga enkäter jämfört med i snitt fem för hela urvalet. Av figur 2 framgår att nästan 80 procent av de dedikerade deltagarna besvarade den dagliga enkäten upp till tio dagar i följd. I kontrast till detta går det att konstatera att deltagandet i den dagliga enkäten sjönk förhållandevis snabbt bland övriga deltagare.

Med tanke på att det oss veterligen saknas forskning som behandlar deltagande $\mathrm{i}$ studier med liknande studiedesign, instrument och population är det svårt att uttala sig om hur dessa resultat ska tolkas. Däremot ger resultaten vissa tydliga indikationer på hur STUNDA och dess funktioner har använts. Å ena sidan besvarades den dagliga enkäten i större utsträckning än snabbenkäten, något som sannolikt kan förklaras av att den förstnämnda var deltagarinitierad och kunde besvaras närhelst det fanns tid och möjlighet. Eftersom snabbenkäten endast var aktiv i 20 minuter från dess att en notifikation mottagits innebar detta sannolikt att många snabbenkäter förblev obesvarade på grund av att deltagaren inte såg notifikationen i tid eller helt enkelt inte hade tid eller möjlighet att besvara enkäten vid det specifika tillfället. Detta innebär även att STUNDA i huvudsak har genererat fler svar på enkäter i relation till ett mini-longitudinellt perspektiv (som var syftet med den dagliga enkäten) jämfört med svar på enkäter i relation till att undersöka trygghetsupplevelser i situationer (som var syftet med snabbenkäten). 


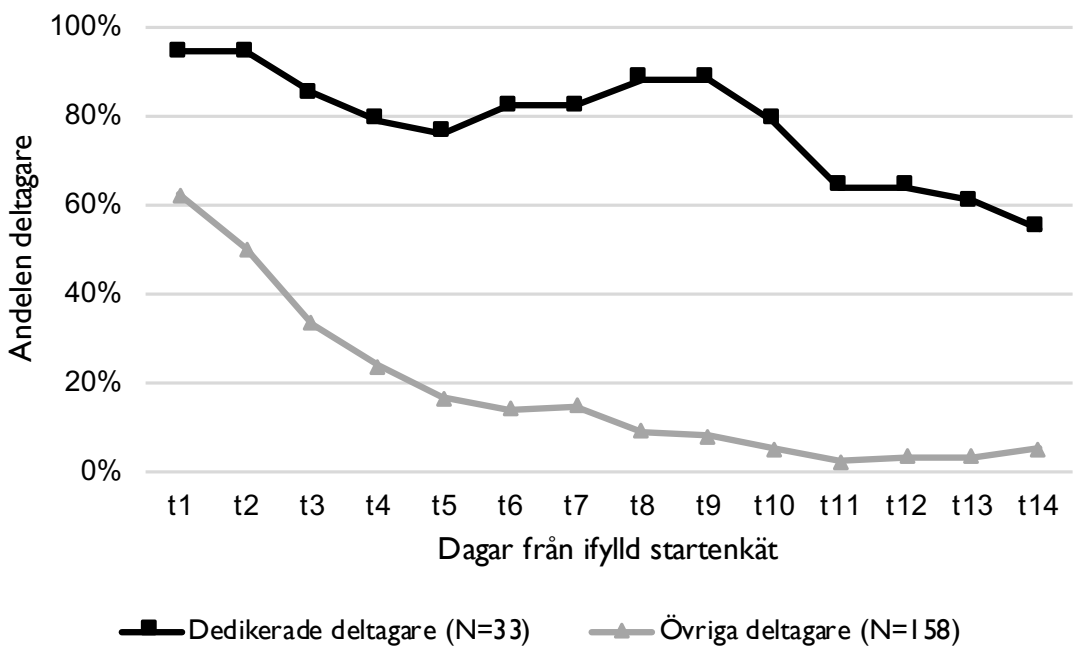

Figur 2. Skillnader i andelen deltagare som besvarat den dagliga enkäten över tid mellan dedikerade deltagare $(N=33)$ och övriga deltagare $(N=158)$.

Att en mindre grupp dedikerade deltagare besvarade en majoritet av såväl snabbenkäterna som de dagliga enkäterna leder till ytterligare frågor gällande exempelvis vilka individfaktorer som kan kopplas till denna deltagargrupp. En enkel analys visar exempelvis att denna deltagargrupp utgörs av en större andel kvinnor jämfört med deltagarna i sin helhet. Detta kan bero på olika faktorer men en tänkbar förklaring är att kvinnor är mer angelägna om att få berätta om otrygga upplevelser eftersom de också upplever mer otrygghet jämfört med män (se t.ex. Brå, 2019).

\section{EXEMPEL PÅ VARIATIONER ITRYGGHETSUPPLEVELSER ÖVER KORTARETIDSPERIODER}

Som tidigare poängterats, och till skillnad från mer konventionella trygghetsundersökningar, är ett av syftena med forskningsprojektet STUNDA att undersöka trygghetsupplevelser i relation till kortare tidsperioder snarare än de senaste tolv månaderna. I den dagliga enkäten ställdes därför ett antal frågor relaterade till olika dimensioner av trygghet under det senaste dygnet. Som tidigare påpekats innefattade dessa dimensioner dels konsekvenser av otrygghet (att ta en annan väg eller färdsätt samt avstått aktivitet p.g.a. otrygghet) och dels oro för utsatthet för brott (både oro för sig själv och för andra). 


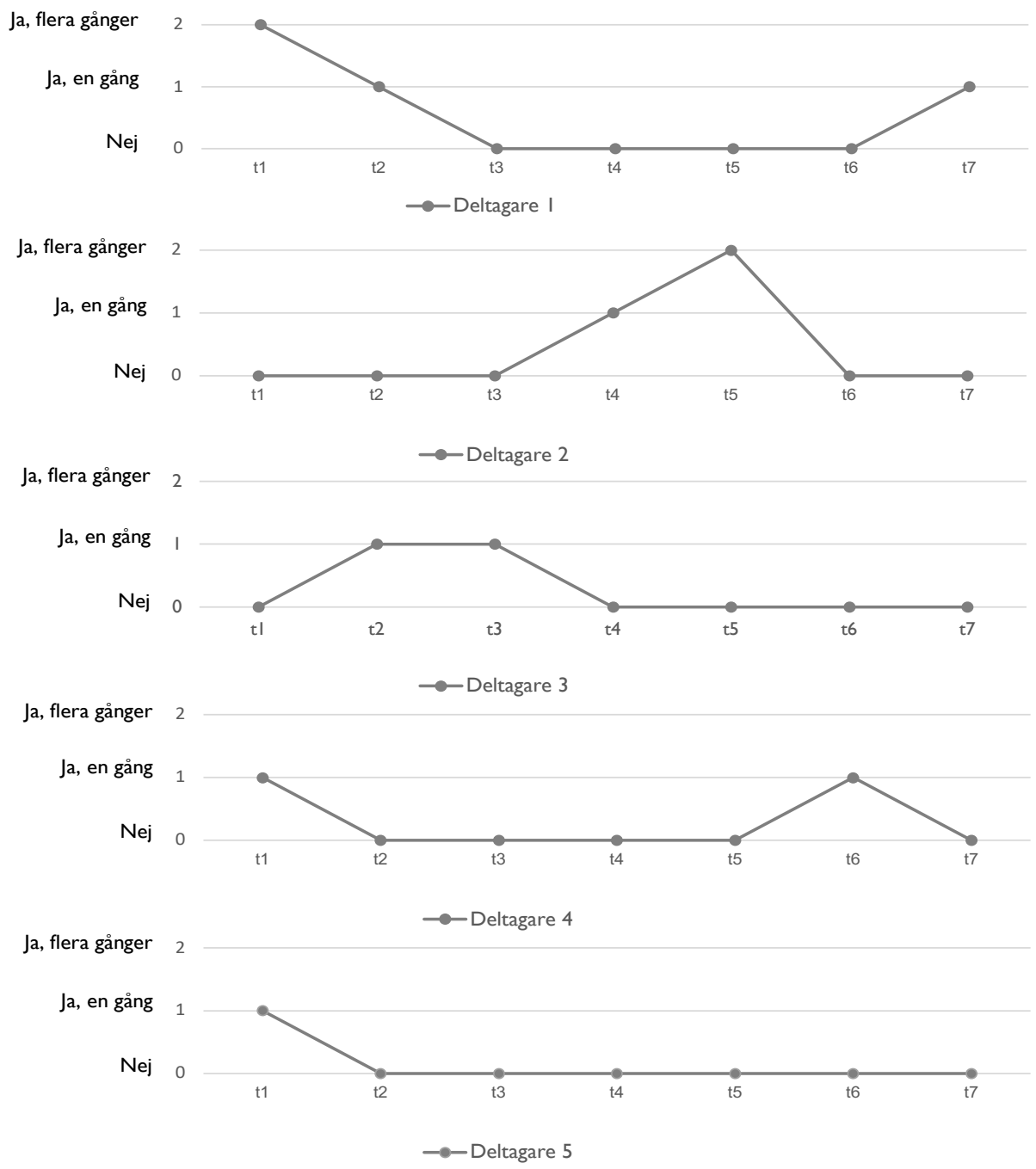

Figur 3. Individuella mönster bland fem deltagare över sju dagar som tagit en annan väg eller ett annat färdsätt de senaste 24 timmarna på grund av otrygghet.

För att illustrera resultaten exemplifierar vi här genom svar ur de dagliga enkäterna från gruppen dedikerade deltagare $(n=33)$ under sju dagar. Resultaten visar att såväl konsekvenser av otrygghet som oro för utsatthet för brott är förhållandevis vanligt förekommande i denna grupp. I omkring 14 procent av samtliga dagliga enkäter uppgav deltagarna att de valt att ta en annan väg eller ett annat färdsätt, alternativt avstått från att delta i en aktivitet, det senaste dygnet på grund av 
otrygghet. I en lika stor andel av de dagliga enkäterna framgick även att deltagarna hade oroat sig för att de själva eller någon närstående skulle utsättas för brott. För att exemplifiera hur upplevelser av trygghet varierar över tid, och för att få en inblick i hur frekvent upplevelser av otrygghet uttrycks i deltagarnas vardagsliv, redovisas fem deltagares svar över en sjudagarsperiod i förhållande till konsekvenser av otrygghet i figur 3 .

Det intressanta i denna figur är att det finns tydliga indikationer på att en och samma deltagares trygghetsupplevelse varierar över kortare tidsperioder. Även om detta resultat inte på något sätt är oväntat är det något som generellt sett har varit svårt att urskilja genom konventionella trygghetsundersökningar där trygghet snarare undersökts i relation till det gångna året eller den senaste månaden, istället för det senaste dygnet. Genom STUNDA går det alltså att få en tydligare indikation på hur frekvent individer väljer att ta en annan väg eller ett annat färdsätt på grund av otrygghet (som i exemplet i figur 3) vilket bidrar till att ge en mer konkret innebörd till svarsalternativen aldrig, sällan eller ofta som i regel används i konventionella undersökningar.

\section{EXEMPEL PÅ SITUATIONELLA FAKTORERS BETYDELSE FÖRTRYGGHETSUPPLEVELSER}

En annan central utgångspunkt för forskningsprojektet STUNDA är att trygghetsupplevelser varierar i relation till olika situationer, det vill säga var en individ befinner sig, vad individen gör och vilka andra personer som är närvarande. Genom snabbenkäten kunde dessa faktorer undersökas närmare och ge en beskrivande bild av de olika situationer som deltagarna upplevde.

I tabell 1 framgår att i två tredjedelar av samtliga svar har deltagaren varit hemma (inklusive hemma hos någon annan), i drygt hälften av svaren har deltagaren antingen arbetat, pluggat eller ägnat sig åt media (t.ex. surfat på mobil, tittat på TV eller liknande) och deltagarna har i huvudsak varit ensamma. ${ }^{1}$

Men vilken koppling finns det mellan olika situationella omständigheter och oro för brott? För att undersöka denna fråga genomfördes bivariata logistiska regressioner där situationer då deltagarna upplevt oro för brott jämfördes med situationer där de inte upplevt någon oro. ${ }^{2}$ Resultaten visar att det finns en högre sannolikhet att uppleva otrygghet när deltagaren antingen transporterade sig någonstans eller mer generellt

I I tabellen har flera olika kategorier slagits samman i övergripande kategorier.

2 I varje situation ombads deltagarna svara på en fråga över hur oroliga de var över att utsättas för ett brott på en steglös skala en (s.k. "slider scale"). Denna variabel hade en för deltagaren dold bakomliggande skala (0-100) som vi för den logistiska regressionen dikotomiserat där noll till nio representerar "ingen oro" och tio till ett hundra "oro". 
befann sig utomhus. Samtidigt framgår hur sannolikheten att oroa sig för brott är signifikant lägre om respondenten var hemma, antingen i sitt eget eller i någon annans hem.

Tabell 1. Situationella faktorer och deras koppling till upplevd otrygghet

\begin{tabular}{|c|c|c|c|}
\hline & $\begin{array}{c}\text { Situationer } \\
\text { totalt }(\%)\end{array}$ & $\begin{array}{c}\text { Otrygga } \\
\text { situationer (\%) }\end{array}$ & Otrygghet \\
\hline \multicolumn{4}{|l|}{ Var är du just nu? } \\
\hline Hemma & 66,4 & 33,3 & $\downarrow$ \\
\hline Arbete/skola & 13,9 & 16,3 & $\nearrow$ \\
\hline Transport & 8,9 & 29,3 & $\uparrow$ \\
\hline Utomhus & 5,2 & 10,6 & $\uparrow$ \\
\hline Övrigt & 5,7 & 10,6 & $\uparrow$ \\
\hline \multicolumn{4}{|l|}{ Vad gör du just nu? } \\
\hline Arbete/utbildning & 28,0 & 24,6 & 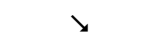 \\
\hline Hushållssyssla & 9,3 & 6,3 & $\searrow$ \\
\hline Inget särskilt & 11,5 & 4,8 & $\downarrow$ \\
\hline I rörelse/på väg & 11,4 & 29,4 & $\uparrow$ \\
\hline Media & 28,7 & 20,6 & $\searrow$ \\
\hline Socialiserar & 9,0 & 7,1 & $\searrow$ \\
\hline Träning/sport/aktivitet & 2,1 & 4,8 & $\uparrow$ \\
\hline \multicolumn{4}{|c|}{ Vilka personer är du med just nu? } \\
\hline Ensam & 43,6 & 48,8 & $\nearrow$ \\
\hline Obekanta & 11,7 & 24,4 & $\uparrow$ \\
\hline Ensam $^{\star}$ Obekanta & 7,0 & 18,7 & $\uparrow$ \\
\hline Familj & 17,2 & 8,1 & $\downarrow$ \\
\hline Partner & 17,3 & 7,3 & $\downarrow$ \\
\hline Vänner, kollegor, bekanta & 24,4 & 26,8 & $\nearrow$ \\
\hline
\end{tabular}

$\uparrow=$ Statistiskt signifikant ökning; $>=$ Ökning, ej statistiskt signifikant; $〉=$ Minskning, ej statistisk signifikant; $\downarrow$ =Statistiskt signifikant minskning

* Här ett mått på om deltagaren var orolig att utsättas för ett brott i den specifika situationen.

Analysen visar alltså att var respondenterna befann sig när de besvarade snabbenkäten var kopplat till upplevd oro för brott. $\mathrm{Vad}$ respondenten gjorde vid tillfället spelade också en viktig roll. Exempelvis fanns det en ökad sannolikhet att uppleva oro för brott när respondenterna uppgav att de var i rörelse eller på väg någonstans, alternativt tränade, sportade eller utförde någon likande aktivitet. Sist men inte minst visar resultaten även att vilka andra personer som var närvarande hade betydelse för upplevelsen av oro för brott. Att vara tillsammans med familj eller en partner minskade sannolikheten att oroa sig för brott medan närvaron av obekanta personer signifikant 
ökade sannolikheten för att uppleva otrygghet. Närvaron av obekanta personer spelade särskilt stor roll om respondenterna samtidigt uppgav att de var ensamma vid tillfället.

Även om resultaten ovan endast relaterar till olika aspekter av en situation var för sig, det vill säga var respondenten är, vad hen gör och med vem, och inte i en gemensam analys av situationen, ger de viss insikt i det situationella perspektivet på trygghetsupplevelser. Den mest grundläggande slutsatsen är att resultaten indikerar att otrygghet varierar i olika situationer. Det är därmed viktigt att undersöka olika typer av situationer och inte enbart den vedertagna situationen i enkätstudier som fokuserar på otrygghet i relation till att gå ut ensam en sen kväll i bostadsområdet.

\section{BETYDELSE FÖR FRAMTIDEN}

Med utgångspunkt i de tre problem som diskuterades inledningsvis visar pilotstudien att det finns möjlighet att öka kunskapen om otrygghet bland unga personer i Malmö. Trots avsaknad av incitament finns det en vilja att delta i den här typen av undersökningar. Att de som deltar mer frekvent, alltså de vi här kallar dedikerade deltagare, skiljer sig från de andra deltagarna är också något som får betydelse för utformningen av framtida studier. Till exempel kan det vara så att bara vissa grupper är lämpliga att undersöka med den här metoden eller att datainsamlingsinstrumentet behöver anpassas efter olika grupper. Pilotstudien visar även att det är möjligt att genomföra en studie där individer följs över tid vilket bidrar till kunskap om hur tryggheten varierar över kortare perioder. Slutligen kan också problemet med avsaknad av kunskap om olika (o)trygga situationer lösas genom att pilotstudien visar att data kan samlas in om specifika situationer $i$ individers vardagsliv.

Utifrån dessa slutsatser skulle nästa fas i projektet kunna bestå av ett test i en större population för att generera generaliserbara resultat, till exempel bland ungdomar i olika åldrar på Malmös skolor. Ett annat möjligt framtida användningsområde kan vara att rikta in sig på de grupper som är särskilt drabbade av otrygghet och kan ses som en sorts dedikerade deltagare. Oavsett framtida studier är det dock viktigt att betona att projektet genom de nya metodologiska perspektiven bidrar till diskussionen om hur (o)trygghet egentligen bör mätas. Således kan studien ses som både ett specifikt lokalt projekt för att öka kunskapen om (o)trygghet bland unga i Malmö och som ett bidrag till trygghetsforskningens utvecklingsmöjligheter i ett större, mer generellt perspektiv. 


\section{REFERENSER}

Averdijk, M., \& Bernasco, W. (2015). Testing the situational explanation of victimization among adolescents. Journal of Research in Crime and Delinquency, 52(2), 151-180.

Bernasco, W., Ruiter, S., Bruinsma, G. J. N., Pauwels, L. J. R., \& Weerman, F. M. (2013). Situational causes of offending: A fixed-effects analysis of space-time budget data. Criminology, 51(4), 895-926

Brottsförebyggande rådet (Brå) (2019). Nationella trygghetsundersökningen 2018: Om utsatthet, otrygghet och förtroende. Rapport 2019:1. Stockholm: Brottsförebyggande rådet.

Chataway, M. L., Hart, T. C., Coomber, R., \& Bond, C. (2017). The geography of crime fear: A pilot study exploring event-based perceptions of risk using mobile technology. Applied Geography, 86, 300-307.

Davidsson, P., Palm, M., \& Melin Mandre, Å. (2018). Svenskarna och internet 2018. Rapport. Internetstiftelsen. Hämtad 2019-09-10. Tillgänglig: https://internetstiftelsen.se/docs/Svenskarna_och_internet_2018.pdf

Engström A., \& Kronkvist K. (2018) Situating fear of crime: The prospects for criminological research to use smartphone applications to gather experience sampling data. In: G. Leventakis, \& M. Haberfeld (eds) Community-oriented policing and technological innovations. SpringerBriefs in Criminology. Springer, Cham

Farrall, S., Bannister, J., Ditton, J., \& Gilchrist, E. (1997). Questioning the measurement of the 'fear of crime': Findings from a major methodological study. British Journal of Criminology, 37(4), 658-679.

Ferraro, K. F. (1995). Fear of crime: Interpreting victimization risk. Albany, NY: State University of New York Press.

Ferraro, K. F., \& LaGrange, R. (1987). The measurement of fear of crime. Sociological Inquiry, 57(1), 70-97.

Hale, C. (1996). Fear of crime: A review of the literature. International Review of Cictimology, 4, 79-150.

Heber, A. (2008). En guide till trygghetsundersökningar om brott och trygghet. Göteborg: Tryggare mänskligare Göteborg.

Hermansson, K. (2018). Den svenska tryggheten: En studie av en kriminalpolitisk symbol. Sociologisk Forskning 55(2-3), 179-202.

Hough, M. (2004). Worry about crime: Mental events or mental states? International Journal of Social Research Methodology, 7(2), 173-176.

Ivert, A-K., Chrysoulakis, A., Kronkvist, K., \& Torstensson Levander, M. (2013). Malmö områdesundersökning 2012. Lokala problem, brott och otrygghet. Rapport från institutionen för kriminologi. Malmö: Malmö högskola.

Ivert, A-K., Torstensson Levander, M. \& Mellgren, C. (2015). Den ojämlika 
otryggheten - stabilitet och förändring i bostadsområden över tid. Socialvetenskaplig Tidskrift, 22(3-4), 211-229

Larson, R., \& Csikszentmihalyi, M. (1983). The experience sampling method. New Directions for Methodology of Social \& Behavioral Science, 15, 41-56.

Lindström, M., Merlo, J. \& Östergren, P-O. (2003). Social capital and sense of insecurity in the neighbourhood: A population-based multilevel analysis in Malmö, Sweden. Social Science \& Medicine 56(5), 1111-1120.

Malmö stad (2013). Malmös väg mot en hållbar framtid. Hälsa, välfärd och rättvisa. Reviderad upplaga, 3. Malmö: Kommission för ett socialt hållbart Malmö

Malmö universitet (2019). Årsredovisning 2018. Hämtad 2019-09-10. Tillgänglig: https://mau.se/contentassets/7bdcfd2b256b471 eaa465838b51a6b14/arsredovisning_2018.pdf

Mellgren, C. (2011). What's neighbourhood got to do with it? The influence of neighbourhood context on crime and reactions to crime. Doktorsavhandling, Fakulteten för hälsa och samhälle, Malmö universitet.

Mischel, W. (2004). Toward an integrative science of the person. Annual Review of Psychology, 55, 1-22.

Pervin, L. A. (1978). Definitions, measurements, and classifications of stimuli, situations, and environments. Human Ecology, 6(1), 71-105.

Regeringen (2018). Regleringsbrev för budgetåret 2019 avseende Polismyndigheten.

Skogan, W. G. (1986). The fear of crime and its behavioral implications. In: Fattah, E. A. (ed.), From crime policy to victim policy. Reorienting the justice system. London: McMillan Press, s. 167-188.

Solymosi, R., Bowers, K., \& Fujiyama, T. (2015). Mapping fear of crime as a contextdependent everyday experience that varies in space and time. Legal and Criminological Psychology, 20(2), 193-211.

Stafford, M., Chandola, T., \& Marmot, M. (2007). Association between fear of crime and mental health and physical functioning. American Journal of Public Health, 97(11), 2076-2081.

Stjernborg, V. (2017). Experienced fear of crime and its implications for everyday mobilities in later life: An ethnographic case study of an urban Swedish neighbourhood. Applied Mobilities, 2(2), 134-150.

Sullivan, C. J., \& McGloin, J. M. (2014). Looking back to move forward: Some thoughts on measuring crime and delinquency over the past 50 years. Journal of Research in Crime and Delinquency, 51(4), 445-466.

Sydsvenskan (2018). Brotten minskar - men fler är otrygga. 29 augusti, s. 2-3.

van Berkel, N., Ferreira, D., \& Kostakos, V. (2018). The experience sampling method on mobile devices. ACM Computing Surveys 50(6), Article 93.

Wikström, P. O. H., Oberwittler, D., Treiber, K., \& Hardie, B. (2012). Breaking rules: The social and situational dynamics of young people's urban crime. Oxford: Oxford 
University Press.

Wilson, J. Q., \& Kelling, G. L. (1982). The police and neighborhood safety: broken windows. Atlantic Monthly, March 1982, 29-38. 


\title{
Elever som subjekt och aktörer med potential - om historieundervisningens existentiella relevans
}

\author{
Jonas Sjölander
}

Det är avgörande att inte sänka förväntningarna på skolan som transformativ kraft för ökad social mobilitet och att inte tappa tilltro till alla elevers möjligheter att utveckla förmågor (Widigson, 2013 s. 274).

Larmrapporter om bristerna i den svenska skolan är återkommande. Svaga elever tappar ännu mer under skoltiden, konstateras det exempelvis i en artikel i Sydsvenskan i november 2018 (SDS 2018-11-04). Skillnaderna mellan "svenska" och "invandrade barn” är större än i de flesta andra länder, står det också i artikeln. Det är elevernas livsvillkor och bakgrund som fäller avgörandet och som påverkar barn och ungas skolgång. Artikeln i Sydsvenskan rör sig tematiskt kring företeelser som är en stor del av vardagen vid Malmös skolor och som är en ständigt återkommande utmaning för skolförvaltningarna i staden. Det är inte heller någon tvekan om att det är Malmö som i artikeln utgör själva sinnebilden för och arketypiskt exempel på det problemområde som behandlas. Och visst stämmer bilden på många sätt. Det har till exempel under senare tid visat sig att en allt för stor andel av eleverna inte når kunskapsmålen i Malmö. Så är fallet i såväl grund- som gymnasieskolan och det är framför allt elever från socialt utsatta områden och kommunala icke-prestigeskolor som inte når fram. Men det finns också exempel på motsatsen även i Malmö; skolor som lyckas trots svåra förutsättningar och som sällan uppmärksammas i media.

I detta antologibidrag pläderas för betydelsen av historisk kunskap om människor och företeelser i historieundervisningen som ofta dolts i den traditionella historieskrivningen eller har betraktats som ointressanta i största allmänhet. Det behövs också former för lärande som påverkar både lärare och elever och där bådadera blir aktivt involverade i sökandet efter kunskap. Ingetdera är möjligt utan relationer. Det här antologibidraget kan betraktas som ett försök att bidra med perspektiv som kan utmana såväl segregerande mönster som skolans och undervisningens alienerade drag. Ett sätt att åstadkomma en sådan överbryggning kan vara att skapa rörelser och möten över stadens geografiska, sociala och kronologiska gränsdragningar i historieundervisningen. Det handlar både om att organisera skolorna på ett sätt som möjliggör detta och om att använda undervisningsmetoder som gör, i det här fallet, historieämnet existentiellt relevant och där eleverna erkänns som subjekt med potential. 
Skoldebatten förs inte bara i media. En vanlig uppfattning bland lärare och inom skolforskningen, såväl internationellt som i Sverige är att läraren är under hot och att det pågår en avprofessionalisering av yrket. I Sverige har Per Kornhall och flera andra skoldebattörer kritiserat utvecklingen inom skolans värld på liknande grunder. Läraryrket och lärarnas kärnuppdrag urholkas på sitt innehåll i takt med att alltfler arbetsuppgifter och nya krav läggs på lärarnas axlar, menar kritikerna. Lärarens auktoritet och autonomi eroderar vilket också minskar yrkets attraktionskraft. Läraren måste få vara lärare, är ett återkommande credo som förs fram bland många av debattörerna. Kritiken landar ibland hårt mot både lärarutbildningen som utbildningsinstitution och pedagogiken/utbildningsvetenskapen som forskningsfält. Verksamheten här har enligt kritikerna varit alldeles för dominerad av postmoderna teorier, konstruktivism och relativistiska utgångspunkter, vilket har medfört att undervisning och ämneskunskap har hamnat i bakgrunden. Vissa kritiker menar till och med att vi har fått en flumskola och att det i stor utsträckning är skolforskningen och lärarutbildningarna i landet som bär ansvar för och skuld till förfallet. Det rör sig om en spretig debatt där utgångspunkter och slutsatser inte alltid är förenliga. Vissa av de sistnämnda kritikerna tycks snarast vilja se en återgång till en skola så som den såg ut i Sverige för 50 år sedan, eftersom de menar att förfallet inom svensk skola inleddes med 1960-talets skolreformer. Några av dessa debattörer, som till exempel den före detta vicerektorn för Karolinska institutet, Martin Ingvar, och den pensionerade professorn i spanska, Inger Enkvist, för fram ståndpunkter som dessa i en bok med den kryptiska titeln Kunskapssynen och pedagogiken - varför skolan slutade leverera och hur det kan åtgärdas. Titeln är trots de oklara syftningarna intressant. Den antyder att skolan är en del i ett leveranssystem som har havererat. Skolan tycks alltså betraktas som en produktionsenhet där råmaterialet kommer in i ena änden och ut i den andra som förädlade och bearbetade varor redo för marknaden. Författarna avfärdar och ställer stora delar av den pedagogiska och didaktiska forskningen från de senaste decennierna åt sidan. Skälet till detta är att den med sin anything-goes-filosofi anses ha förstört skolan, vilket resultaten från PISA:s undersökningar får bekräfta. Den relativistiska och kunskapsföraktande subjektivismen måste därför ryckas upp med rötterna (Magnus Henrekson et al, 2017). Inger Enkvist har senare i en intervju under hösten 2018 hävdat att de "sociala aspekterna har fått högre prioritet än kunskapskraven" i den svenska skolan och att den präglas av "en jämlikhetsideologi där alla ska studera samma sak i samma klassrum" (Intervju med Inger Edkvist, Edico, nr 6: 2018). Bland debattörerna inom detta läger förekommer inte sällan populistiska, förenklade och generaliserande påståenden om tillståndet i den svenska skolan som i regel presenteras i form av drastiska och icke-falsifierbara slutsatser med vidhängande förslag till mirakelkurer. Andra tar istället lärarnas parti och menar att läraryrket som, hävdas det, är bland det viktigare i ett civiliserat samhälle, måste få tillbaka sin status och fyllas med det innehåll det förtjänar. Ytterligare andra kritiserar marknadifieringen av skolan, kund- och resultatorienteringen, som ofta går under beteckningen New Public Management. Även här förekommer det kritik mot att nya arbetsuppgifter läggs på lärare - arbetsuppgifter som inte har med det undervisande kärnuppdraget att göra: systematiskt 
kvalitetsarbete, ekonomisk styrning och decentraliserade organisationer där administrativa uppgifter sprids från chefs-och tjänstemannanivåerna till verksamheten. Per Kornhall är kritisk till företeelser som dessa och till 1990-talets skolreformer liksom brister i likvärdighet. Men han är även kritisk till vad som ofta benämns som det postmoderna inflytandet på skolan och ser sig därför föranledd att hävda att kunskap faktiskt kan överföras (Kornhall, 2018). Läraren Isak Skogstad är en annan flitig skoldebattör som bland annat menar att lärarna måste befrias från socialt ansvar till förmån för det undervisande uppdraget och kunskapsförmedling.

Gemensamt för såväl de förra som de senare debattörerna är att eleverna suddas ut som subjekt i argumentationen. De framstår nästan uteslutande som objekt för skolans och lärarnas interventioner och instruktioner. Oavsett utgångspunkt och oberoende av vilka slutsatser som dras i debatten om den svenska skolan och skolpolitiken är det uppenbart att det finns problem. Det finns dock inga snabba lösningar eller entydiga orsakssamband. Den onda cirkeln tar sig bland annat uttryck i lärarbrist och svårigheter att rekrytera studenter till lärarutbildningarna vid universiteten. Segregationen och den socioekonomiska polariseringen, som är särskilt påtaglig i Malmö, medför att klimatet hårdnar i samhället och därmed också i skolorna. Detta ställer stora krav på skolan som måste härbärgera utbildad och kompetent personal, resurser och förmåga att skapa en skola där eleverna är trygga, sedda och studiemotiverade. En återgång till renodlad överföringspedagogik vore dock enligt min uppfattning förödande. Framför allt måste eleverna betraktas som subjekt i verksamheten som bedrivs vid skolorna - inte enbart ur allmänpedagogisk eller allmändidaktisk synvinkel utan även i fråga om själva ämnesinnehållet. I det följande kommer historieundervisningen, dess ämnesinnehåll och former, samt den relationella pedagogikens betydelse att diskuteras i ett Malmöperspektiv.

Min utgångspunkt är helt enkelt att alla som har levt, lever och kommer att leva i Malmö är en del av och äger rättigheterna till stadens historia, samtid och framtid. En förutsättning för att de vuxna pedagogerna i Malmös skolor ska kunna övertyga eleverna om att så är fallet är att undervisningen innehåller en relationell dimension. Eleverna måste, menar jag, till skillnad från ovan nämnda skoldebattörer, tillåtas att vara subjekt och läraren måste hitta vägen till en existentiellt relevant historieundervisning genom det som finns inom och omkring eleverna. Historikern Rolf Torstendahl lanserade för en sisådär 40 år sedan begreppen minimikrav och optimumnormer för att skilja icke-vetenskap från vetenskap samt vetenskap som lyfter sina vingar från minimikravens grundläggande anständighetsnivå, det vill säga de krav som måste uppfyllas för att vetenskapen överhuvudtaget ska kunna kallas för vetenskap. Han återkommer även till begreppen i sin senaste bok Den historiografiska revolutionen 1960-1990 (Torstendahl, 2017). Optimumnormerna förutsätter att ett antal kvalitetskriterier för vad som är intressant eller relevant vetenskap blir uppfyllda. Med de vetenskapliga, kumulativa och teoretiska relevanskriterierna sätts problemet $\mathrm{i}$ ett sammanhang och förbindelse med tidigare forskning, samhälls- och historieteori. Historikern Ingemar Norrlid utvecklade idén ytterligare 20 år senare och lade särskild vikt vid den existentiella relevansen, på ett sätt som har varit en viktig källa till inspiration för den här antologitexten. Med det existentiella kriteriet för relevans sätts 
människans problem och existensvillkor i centrum (Rolf Torstendahl, 1979; Ingemar Norrlid, 1999). Torstendahls begrepp och metod för att kvalitetssäkra historievetenskapen fungerar även som ett sätt att tänka kring undervisning i historia.

Detta är angeläget inte minst som ett svar på kraven att sätta "faktakunskaper" i fokus i historieundervisningen. I dessa sammanhang tenderar kravställarna ofta glömma att det existentiella relevanskriteriet rymmer något större och något som är mer än bara fakta. God historieundervisning rymmer därtill det relationella perspektivet och här måste mötet med eleverna spela en avgörande roll - det är nämligen där det avgörs om undervisningen blir meningsfull och relevant. Det här antologibidraget har skrivits i syfte att betona dels det potentialorienterade och relationella förhållningssättet $\mathrm{i}$ undervisningssammanhang, dels vikten av att historieundervisningen till innehåll och form lever upp till det existentiella relevanskriteriet. Båda dessa delar är nödvändiga ingredienser om vi vill att elevers kraft att lära och erövra kunskaper ska frigöras.

\section{DÄR ELEVERNA BEFINNER SIG}

De strukturella orsakerna till skolsegregationen ligger bortom skolornas och skolförvaltningarnas påverkanshorisont. Däremot kan skolorna spela en roll för eleverna som individer och fungera som mötesplatser där de får tillfälle och möjlighet att existera utanför kategoriseringarnas ramar. De dominerande bilderna av förorterna och miljonprogramområdena som parallellsamhällen, utanförskapsområden med egna normer, regler och sociala koder får också betydelse och mening för skolsegregationen (Dahlstedt, 2018). Invånarna i städernas förorter betraktas implicit eller explicit som problem (Se även Lozic, Ljungberg och Harju i denna antologi). Förväntningarna på barn och unga är starkt präglade av bristperspektiv och bilder där invånare i hela stadsdelar i det offentliga samtalet gestaltas som bärare av tillkortakommanden. Mer än halva elevpopulationen i Malmös kommunala grundskolor, det vill säga majoriteten, har invandrar- eller flyktingbakgrund och tillhör alltså inte den elevkategori som i Sydsvenskan går under beteckningen "svenska elever". Om dessa elever inte är svenskar - vad är de då? Är det möjligen så att kategoriseringen av dem som svaga och icke-svenska elever medför att de betraktas som tillfälliga eller permanenta besökare i staden Malmö? Är de en del av staden och stadens historia? Finns det något relevant existentiellt argument för eleverna att intressera sig för stadens historia och miljö, eller ska de anta turistens och den tillfällige museibesökarens perspektiv och förhållningssätt? Om eleverna själva upplever sig som exkluderade, vid sidan av och som motvilligt emottagna besökare, utan tillträde till det "det svenska" är risken överhängande att hindren blir oöverstigliga.

Det omgivande samhällets definitioner och kategoriseringar av eleverna är både många och oklara, men gemensamt för dem är att de för det mesta fungerar 
särskiljande. Även de mest välvilliga kategoriseringarna kan innehålla exkluderande anslag och inslag - från Skolverkets märkliga definition av "nyanlända elever" (mindre än 4 år i svensk skola) till begreppet "annan bakgrund". Det alltmer polariserade klassamhällets och det neoliberala paradigmets sociala konsekvenser tonas ned i det offentliga samtalet - exempelvis på ledarsidorna i Göteborgsposten eller i den politiska debatten - i stället hamnar annorlundahet och kulturella skillnader i förgrunden. I förstäderna finns de potentiella terroristerna, de kriminella och utövarna av hedersvåld: där finns de andra och där finns de andras barn. Vissa skolor reserveras för de andras barn - de svaga barnen; medan andra skolor, prestigeskolorna, reserveras för de starka svenska barnen och barn med utländsk bakgrund som har föräldrar med kraft och förmåga att välja. Så ser det fria skolvalets konsekvenser ut. Skolorna och skolförvaltningarna i staden har begränsade möjligheter att påverka var eleverna hamnar. Valfriheten och skolsegregationen är reglerad och cementerad av lagstiftning.

I Malmökommissionens huvudrapport framgår att ojämlikheten och skillnaderna i barn och ungas livsvillkor är påtagliga i Malmö. Även om det 2013, när Kommissionens rapport publicerades, delvis saknades systematiska undersökningar och data, fanns det tillräckliga belägg för att konstatera att så var fallet. Det var till och med sannolikt att kommissionens utsagor var en underskattning av den verkliga situationen, konstaterades det i rapporten. Skillnader i livsvillkor kunde fastställas med avseende på hälsa, boendeförhållanden och socioekonomisk status vilket också förde med sig skillnad i kognitiva förmågor hos barnen i jämförelse. En av de största utmaningarna för kommunen och skolförvaltningarna har följaktligen under det senaste decenniet varit att bryta mönster av segregation och social exkludering. Detta är en komplex och mångfacetterad fråga. Segregationen uppstår som ett led i många parallella processer. Det går inte ignorera att majoritetssamhällets - ett problematiskt begrepp i Malmö, med tanke på befolkningsstrukturen - underliggande normer och etablerade förväntningar på "den andre" spelar roll i de processer som reproducerar och vidmakthåller den rådande ordningen. Den forskning som finns på området visar också att föräldrarnas utbildningsbakgrund och sociala position i hög grad blir bestämmande för elevernas resultat (Lund \& Lund, 2016). Mottagandet av nyanlända flyktingar och formerna för detsamma har varit en återkommande fråga för diskussioner och utredningar i Malmö. Även undervisningen och den ämnesdidaktiska praktiken kan i detta sammanhang betraktas ur ett kritiskt reflekterande perspektiv, exempelvis genom att påvisa hur normer för svenskhet, invandrarskap och stereotypisering överförs genom själva skolämnena (Svensson Källberg, 2018). Ses de nyanlända elevernas livsvärldar och erfarenheter som resurser i lärandet eller betraktas de som tomma men annorlunda behållare för påfyllning?

Mot bakgrund av befintlig forskning på området finns det också anledning att aktualisera och fästa blicken på skolans kompensatoriska uppdrag. Detta är också ett framträdande inslag i Malmökommissionens slutrapport, vilken alltjämt utgör riktningsgivare i utformningen av de kommunala verksamheterna i Malmö. (Malmös väg mot en hållbar framtid. Hälsa, välfärd, rättvisa. Kommission för ett hållbart Malmö, 
Malmö 2013) Det är alltså ett uttalat och politiskt mål att skolan skall bidra till att överbrygga socioekonomiska klyftor och segregationsmönster. Riktlinjer, direktiv och högt ställda politiska mål är en sak; den vardagliga dynamiken och praktiken är en annan. Skolsystemets organisering avspeglar politiska beslut, lagstiftning och socioekonomiska strukturer i det samhälle där den sker. Skolförvaltningarna och skolorna kan inte påverka själva utgångspunkterna för verksamheten i strukturell mening. Men! Skolan som en plats för interaktion, lärande och pedagogisk kraft är likväl intakt oberoende av var den är belägen i staden - skolan är en plats där eleverna kan bli synliga som subjekt och i sin fulla potential. Den principen är också reglerad i läroplan och skollag. Skolorna i Malmö trotsar skolsegregationen genom att samarbeta sinsemellan och utveckla mötesplatser över skolgränserna från Strandskolan i väster till Apelgårdskolan i öster. Ett exempel på detta är projektet Grundskolefotboll mot rasism - för allas lika värde som organiseras av avdelningen Pedagogisk inspiration i Malmö stad i samarbete med Malmö FF, en rad organisationer från civilsamhället och de deltagande skolorna där elever från flera Malmöskolor i årskurs 6 möts inte bara för att spela fotboll tillsammans - pojkar och flickor från olika skolor och miljöer i samma lag. Här får elever också tillfälle att mötas och interagera över de segregerande demarkationslinjerna i samtal om barnkonventionens principer och barns universella rättigheter. Tanken är att möten som dessa löser upp dikotomin "vi och dom" och omvandlas till ett "vi". I årskurs 7 arbetar samma elever i bokprojektet "Stjärnresan", där elevernas berättelser publiceras i en tjock och fin bok i antologiserien med samma titel (Stjärnresan 3, Malmö 2018). De nära 1000 elever och författare som har medverkat med sina berättelser i de tre antologierna är ett vi utan något dom.

\section{HISTORIA UNDERIFRÅN - UNDERVISNING I GLOBAL OCH LOKAL KONTEXT}

Malmö är en stad som växer och inflödet av människor som flyr krig och förtryck är ständigt pågående. Mängder av människor som faktiskt är och har varit subjekt i skapandet av staden har exkluderats från berättelserna om densamma. Frågor om rätten till staden och nödvändigheten att se bortom och bakom de officiella källorna har sedan länge uppehållit historiker och sociologer som har opponerat sig mot och förhållit sig kritiska till den traditionella historieskrivningen. Den brittiske historikern E P Thompsons klassiker A Making of the English Working Class är ett exempel (Thompson, 1963). Även Henri Lefebvre betonade sambanden mellan rätten till staden och berättelserna om staden (Merrifield, 2006). Rätten till staden har i detta hänseende existentiell relevans, vilket också är ett bärande tema i en artikel av David Harvey som inspirerad av Lefebvre slår fast att rätten till staden handlar om något större än endast bara den individuella friheten att få tillgång till stadens resurser. Han pekar på 
alla stadsinnevånares rätt att få existera och att få vara med att skapa och sätta avtryck i såväl gestaltningar som omgestaltningar av staden. Harvey betraktar detta som en mänsklig rättighet (Harvey, 2008). I sin förlängning borde rätten till staden kanske till och med även omfatta stadsinnevånare som sedan länge är döda; människor som har byggt städerna och varit en del av dem, men som inte syns eller får ta plats och gestalt i de offentliga källorna.

Det underifrånhistoriska perspektiv som lyfts fram här anknyter till den begreppsliga innebörd och historiesyn som presenterades i de två antologierna Tycka, tänka tro och Bygga, bryta, bo i början av 1990-talet (Broberg, Wikander \& Åmark, 1993, 1994). Där konstaterades att alla människor har rätt till sin historia, även de undanskuffande och osynliga. Kvinnor, barn, åldringar, sjuka, fattighjon har lika stor rätt att synas i historien som de framgångsrika, förmögna och prominenta personerna. Alla har dessutom rätt att bli synliga som individer, inte endast som anonyma beståndsdelar i strukturer eller sociala kollektiv. Även arbetet lyftes fram som intressant att studera inte minst för att det genom historien har skapat rikedomar och överskott som har fördelats ojämnt och koncentrerats till härskande minoriteter i samhället. Kroppens historia är ytterligare en tematik. Genom historien har människor älskat, skrattat och gråtit. Människors kroppar har pryglats, bestraffats och fängslats. Kroppar har dolts med kläder som signalerat status och position. Kroppar har utsatts för smittor och sjukdomar och den medicinska vetenskapen har i olika tider haft olika svar på frågan om hur kroppen ska botas och behandlas. Tankar, idéer, föreställningar om världen, livet och döden har förändrats och omformulerats genom historien och de har sett olika ut beroende på position och status. Därför blir det underfrånhistoriska perspektivet också ett inifrånhistoriskt sådant. Här återfinns kritiska förhållningssätt som omsatta i historieundervisningens praktik skulle kunna bidra till överskridande möten och emancipatoriska rörelser i konkret mening vilket medför ett erkännande av eleverna som aktiva och medskapande subjekt $i$ historien. Elever med erfarenhet av migration, exiltillvaro, flykt, krig och umbäranden i andra världsdelar måste betraktas som ovärderliga resurser i ett sådant sammanhang. De är någonting annat än svaga bärare av tillkortakommanden, problem och annorlundahet.

Ett sätt att förebygga och överbrygga social exkludering, stigmatisering och motverka segregation är att skapa förutsättningar för positiva lärmiljöer i områden och skolor som saknar social prestige och status. Undervisning med pedagogiska kartor och historiska vandringar som bedrivs i Malmö sedan 2016 - och dessförinnan under flera år med erfarenhetsbaserad pedagogik inom Naturskolans regi - skulle kunna vara exempel på just detta (Schilhab \& Lindvall, 2017). Utarbetandet av pedagogiska kartor, organiseringen av stadsvandringar, källkritiska lokalhistoriska studier och övningar har potential att ge ämnet existentiell mening och relevans för både lärare och elever (se Malmö stads hemsida Pedagogiska kartor). Genom stadsvandringar och källkritiska övningar finns det möjlighet att arbeta med att upptäcka hur staden Malmö har förändrats geografiskt, socialt och kulturellt genom århundradena. Om eleverna erfar att de själva hör samman med, är en del av och har betydelse för stadens kontinuitet och förändring kommer historieämnet till sin rätt. 


\section{Den gömda och glömda historien i Malmö Stad - bortom monumenten}

Varje tid har sina monument och i varje tid skapas historia bakom och bortom monumenten. Drygt hundra år efter affärsmannen och företagaren Frans Suells död restes en staty över honom mittemot hamnen i Malmö. Sju år tidigare hade Amalthea-mannen Anton Nilsson och hans kamrater utfört ett attentat mot ett fartyg med strejkbrytare alldeles i närheten av Suell-statyn. En av strejkbrytarna dog. Nilsson satt vid tiden för avtäckningen av statyn inspärrad på Vita Briggen som fängelset i Karlskrona kallades, efter att dödstraffet hade omvandlats till livstids fängelse. Amaltheadådet har kommit att bli en välkänd episod i Malmös och arbetarrörelsens historia. Ömsom har händelsen tonats ned och ömsom lyfts fram beroende på vilka politiska krafter och rörelser som har använt den i sina historiska narrationer (Tidman, 1998).

På en hästrygg på Stortorget i Malmö tronar Karl X Gustav, som sägs ha haft samma midjemått som han var lång. Det är inte ett monument över de tiotusentals soldater som slaktades eller sket ihjäl sig i de många och blodiga erövringstågen som kungen gav sig ut på för att etablera och konsolidera den svenska stormaktstatusen under 1600-talets mitt. Monumentet är en kvarleva från det nationalistiska 1800-talet. Nationalismen som idé var långt ifrån unik för Malmö och Sverige. På kontinenten blev den en av faktorerna bakom och det ideologiska bränslet för två blodiga världskrig under 1900-talet. När Frans Suell-statyn avtäcktes år 1915 hade antimilitarismen och fredsaktivismen tryckts tillbaka av nationalistisk yra och en känsla av oövervinnerlighet i såväl England, som Frankrike och Tyskland. Suellstatyn är inte ett monument över de bröduppror som faktiskt utbröt i Malmö på 1820-talet strax efter Frans Suells död. Statyn har dessutom ryggen vänd mot det spinnhus dit normbryterskor förpassades till straffarbete (Sundman-Marknäs, 2012). Istället är det betydelsen av en driftig köpman, som visste hur det gick till att köpa billigt och sälja dyrt som lyfts fram. Sammanslagningen av Suells och Kockums ekonomiska imperier påverkade onekligen staden och livet för generationer av människor under lång tid framöver. Det finns dock många berättelser i Malmö att utforska och många frågor att ställa som inte tar sin utgångspunkt i enskilda personer som har avbildats i monument:

- Barnarbete vid Suells tobaks- och textilindustrier. Vad säger det oss om vår egen och dagens globala klyftor? Barnarbete och slaveri är idag mer omfattande än någonsin förr, men ändå ser vi det som någonting avlägset och som företeelser utan koppling till vår tid och verklighet.

- Vad kan nya och gamla byggnader i Malmö berätta? Vilka bor i Möllevången eller Kirseberg idag och vilka bodde där förr?

- De stora arbetsplatserna Kockumsvarvet och textilindustrin. Vilka arbetade där? Hur och var bodde de? Hur levde de? Vad drömde de om?

- Vilka berättelser finns dolda i de olika migrationsvågorna genom decennierna till staden?

- Vilken betydelse har Öresund haft som migrationsfält genom historien?

- Varför lades varvsindustrin plötsligt ner? 
- Hur kan det komma sig att eternitfabriken i Lomma lades ner och att samhället numera är en sovstad till Malmö med dyra och exklusiva bostäder, båtar och restauranger belägna ett stenkast från stranden?

I de traditionella narrativen över såväl centralmaktens historia som den lokala historien, i det här fallet Malmös, är begrepp som "storhetstid", "blomstringstid", "uppgång" och "nedgång" vanligt förkommande. Begreppen avser att beteckna ekonomiskt starka respektive svaga perioder, eller perioder där staden haft en särskilt politisk och kulturell betydelse i förhållande till kungadömena i Danmark och Sverige. I en äldre konservativ och i viss mån nationalistisk historieskrivning har i båda länderna det ena nationella inslaget uppvärderats i förhållande till det andra. Under sista delen av 1800-talet växte historia fram som en akademisk genre i Europa och historieämnet blev en viktig komponent i den nationalistiska väckelsen. Historieämnet blev av central betydelse för konstruktionen av stater, nationell identitet och geist. Samtidigt uppträdde socialdarwinistiska filosofier på kontinenten och vissa nationer ansågs mer överlevnadskraftiga än andra, vilket också i förlängningen ledde fram till rasbiologiska föreställningar om ras som också knöts till nationen och kulturgemenskapen. I denna ideologiska miljö uppstod även specifika idéer om hur nationer, raser och kulturgemenskaper hade växt fram på ett organiskt sätt. Som vi alla vet är denna föreställningsvärld alltjämt levande och vinner mark i det svenska politiska landskapet. Detta sätt att se på nationer - som historiskt givna men föränderliga storheter och samhällen - har även kommit att påverka senare historieskrivning och därmed också historieundervisningen. Det märks inte minst i värderingen av vad som anses vara historiskt intressant och tvärtom. Den svenska politiska historien är fortfarande dominant så till vida att det än idag finns ett starkt fokus på svenska kungar och krig, svenska prominenta personer, svenska framträdande köpmän, svenska biskopar och adelsmän. Det är segrarnas historia som skrivs eftersom det oftast (inbillar vi oss) är segrarna som är mest synliga och som har satt spår efter sig i såväl skriftliga källor som i form av artefakter och kvarlevor. Den politiska historien kommer alltid ha sin betydelse. Den äger framför allt förklaringskraft när det handlar om ekonomisk och politisk utveckling, förändring och kontinuitet.

Härskarmakten har sedan medeltiden varit knuten till ett fåtal händer. Ekonomiska och politiska maktinnehavare har därför också haft stora möjligheter att sätta avtryck i historien, eller snarare givit dem möjlighet att lägga sig som en blöt filt över de andra som också har existerat och varit betydelsefulla. Vi förknippar dem med särskilda epoker och händelser och de blir betydelsebärande i kronologin så som också vissa årtal kan bli det. Men bakom de framträdande stora männen (för det handlar för det mesta om män), bakom perukstockarna, plymerna, de vunna eller förlorade sjöslagen och de pampiga byggnaderna och slotten fanns småfolket och vardagslivet. Där fanns de människor vars arbetskraft exploaterades, kvinnorna och de sociala strukturer som begränsade det stora flertalets handlingsutrymme. Där levde människorna sina liv, de älskade, åt, svalt och befann sig i konflikt med varandra och ibland också med överheten. Här kan underifrån-historiska aspekter av historien bidra med perspektiv och frågeställningar som levandegör historien och gör den angelägen. Den 
blir existentiellt relevant och sammantvinnas med företeelser i samtiden som eleverna kan relatera och förhålla sig till eftersom de berör deras liv och det de kan känna igen i samtiden. För visst borde det faktum att hälften av arbetarna vid Suells tobaksfabrik i Malmö under tidigt 1800-tal var barn under 14 år kunna väcka intresse och engagemang? Barnarbetet minskade visserligen i betydelse under 1800-talets andra hälft, då Kockum hade tagit över fabriken, men det fanns kvar ännu vid sekelskiftet 1900. Först 1925 hade barn och unga nästan helt försvunnit ur produktionen (Olsson, 1978). Frågan om varför barnarbetet upphörde har varit föremål för olika tolkningar och strider mellan historiker. Den borde vara minst lika spännande att närma sig i historieundervisningen. Särskilt med tanke på att varje inköp som görs i en leksaksaffär, i en $\mathrm{H}$ \& M-butik eller i det småländska möbelvaruhuset vid Svågertorp ger frågan en brännande och dagsfärsk aktualitet. Grundaren av den sistnämnda globala möbelkoncernen lyfts ofta fram som den en typisk representant för svenskt provinsiellt entreprenörskap som har erövrat världen. Kritiken mot företaget (skatteflykt, grundarens sympatier med fascismen, exploatering av råvaror och arbetskraft $i$ tredje världen) trängs i regel undan av den entreprenöriella, nationalistiska och provinsialistiska berättelsen om grundarens förmågor att köpa billigt och sälja lite mindre billigt. Den behöver däremot inte förträngas i historiska undersökningar utförda av elever och lärare på vandring i sin stad. De är fria att tolka och kritiskt granska såväl det nutida som dåtida bruket av historien, liksom de historiska och samtida miljöerna de upptäcker och avtäcker via arbetet med de pedagogiska kartorna.

\section{HISTORIEÄMNET OCH DEN EXISTENTIELLA RELEVANSEN SOMYTA FÖR RELATIONELL PEDAGOGIK}

I radiodokumentären Kvarteret möter vi generationer av människor som har levt och växt upp i ett särskilt område i stadsdelen Kirseberg (Kvarteret, del 1-3, SR P1 Specialprogram). I ett avsnitt fick barn som är elever i en av stadsdelens grundskolor ta del av och konfronteras med dessa berättelser. Eleverna som inte själva bor just här utan i ett intilliggande socioekonomiskt utsatt område ropade högt av förvåning när de upptäckte vilken förändring stadsdelen har genomgått. Plötsligt upptäckte eleverna människor som har levt, skrattat, bullrat, bråkat och kämpat för sin överlevnad via platser och byggnader som nu har reserverats för unga hipsters i karriären. Den pågående gentrifieringen fick en betydelse och mening som skar in i deras tillvaro. Elevernas möten med människorna i berättelserna om stadsdelen tycktes bära på något som skapade engagemang - de hade existentiell relevans och berörde elevernas verklighet och livsvillkor.

Att skapa förutsättningar för den typen av möten borde vara en viktig utgångspunkt för all historieundervisning i grund- och gymnasieskola. Genom att ge sig ut 
med eleverna i staden, arkiven och museerna och tillsammans undersöka vad som döljer sig där går det att åstadkomma lärprocesser där eleverna är aktiva som subjekt och som varelser med potential. Genom att låta eleverna bli en del av och sätta avtryck på den pedagogiska kartan, kan också brottet med den alienerade historieundervisningen och skolpraktiken bli verklighet. Ämnesundervisning är en sak, men mötet mellan lärare och elever handlar till syvende och sist om relationer. Det måste finnas en meningsfull ömsesidighet i mötet dem emellan. Utbildning handlar i grund och botten om "verkliga människor som står i relation till varandra", skriver Jonas Aspelin och Sven Persson i boken Om relationell pedagogik (Aspelin \& Persson, 2011, s.17). Författarna refererar i sammanhanget och ansluter till tankarna i det manifestet för relationell pedagogik som förs fram i Charles Binghams och Alexanders Sidorkins antologi No Education Without Relation (Bingham \& Sidorkin, 2004), i resonemang som ytterst knyter an till synsätt och begreppsvärldar som har varit framträdande inom sociologi och filosofi. Aspelin och Persson pläderar för betydelsen av den relationella pedagogiken vars huvuddrag översiktligt kan sammanfattas enligt följande: Människan och jaget uppstår och utvecklas endast i relation till andra, där hon tillåts vara subjekt i samvaro med andra subjekt. Vardagen i skolan handlar i hög grad om att bygga igenkännbara rutiner, där såväl vuxen personal som elever kan navigera. Detta betyder inte att allt som sker i skolan är förutsägbart. Konflikter och glädjeämnen uppstår oförutsett och oförhappandes, eftersom skolan är befolkad av människor som står i relation till varandra och till världarna utanför skolan. Interaktionen är situationsbunden och komplex. Aspelin \& Persson påpekar att relationell pedagogik bygger på antagandet att relationer är grundläggande för enskilda individer som är relationella jag. Individerna är inte enskilda och isolerade subjekt. De blir till i relation till andra individer och till omvärlden.

Skolan har, skriver Aspelin \& Persson, ett formellt uppdrag: "kunskaper ska förmedlas, eleverna ska utveckla olika färdigheter, förmågor och förhållningssätt". Men den har också en annan uppgift som kanske till och med är överskuggande och viktigast av allt: "Att vara en mötesplats" (Aspelin \& Persson, 2011, s. 152). Denna funktion och uppgift behöver inte vara isolerad till klassrummet, eller ens till skolan som fysisk plats. Alexander Sidorkin, som Aspelin \& Persson ofta refererar till i sin bok, pekar också på vikten av att skolan och utbildningen är meningsfull och existentiellt relevant för eleverna; inte simulerad och alienerad, vilket den och i synnerhet historieundervisningen gärna tenderar att bli. Den blir något för sig och vid sidan av det omgivande samhället.

Det måste finnas en meningsfull och existentiellt relevant ingång för historieämnet. De historiska artefakterna ligger där utströdda i staden och väntar på att bli upptäckta och undersökta. I Stadsarkivet finns berättelserna om människorna från det förflutna. Det som inte kan excerperas kan fantasin och inlevelseförmågan ta hand $\mathrm{om}$. Arbetet med de pedagogiska kartorna kan och borde nämligen även rymma ett relationellt innehåll. Det är inte bara skolan som är en mötesplats. Även staden har potential att vara en pedagogisk mötesplats där kunskaper kan växa. Stadens gränser behöver överskridas kronologiskt, socialt och geografiskt. Genom gränsöverskridande 
möten med såväl levande som historiska och numera döda subjekt skapas existentiell relevans som träffar både pedagoger och elever. Det uppstår en relation till historien $\mathrm{i}$ och mellan människorna som blir till när de står i förbindelse med det förflutna, samtiden, framtiden och varandra. När den förbindelsen har kommit till stånd är också måluppfyllelse uppnådd oberoende av vilka elever det är som har nått dit. Därmed får historieundervisningen även en emancipatorisk dimension genom vilken eleverna kan placera sig ovanför och utanför kategoriseringar och definitioner som å ena sidan utmålar dem som svaga, kulturellt knepiga och osvenska eller starka, oproblematiska och svenska å den andra. Det blir också en historieundervisning som inte fastnar i simpel faktapositivism och som lyfter sitt anspråk och sitt innehåll från minimikrav till optimumnorm.

\section{REFERENSER}

Aspelin, Jonas \& Persson, Sven (2011), Om relationell pedagogik, Malmö.

Bingham, Charles \& Sidorkin, Alexander (2004), No Education Without Relation, New York.

Broberg, Gunnar; Wikander, Ulla \& Åmark, Klas (red:) (1993), Tycka, tänka, tro, Stockholm.

Broberg, Gunnar; Wikander, Ulla \& Åmark, Klas (red:) (1994), Bygga, bryta, bo, Stockholm.

Dahlstedt, Magnus (2018), Förortsdrömmar, utanförskap och viljan till inkludering, Linköping.

Harvey, David,"The Right to the City", New Left Review 53, Sept/Oct 2008.

Henrekson, Magnus; Ingvar, Martin; Enkvist, Inger \& Wållgren, Ingrid, Kunskapssynen och pedagogiken. Varför skolan slutade leverera och hur det kan åtgärdas, Stockholm 2017.

Kvarteret (2018), del 1-3, SR P1 Specialprogram.

Kornhall, Per, "Ärligt talat!, i Skola \& Samhälle, 2018-10-25, https://www.skolaochsamhalle.se/flode/skolpolitik/per-kornhall-arligt-talat/, 2019-06-13

Anna Lund \& Stefan Lund (red.), Skolframgång i det mångkulturella samhället, Lund 2016.

Malmös väg mot en hållbar framtid. Hälsa, välfärd, rättvisa (2013), Kommission för ett hållbart Malmö, Malmö.

Merryfield, Andy (2006), Henri Lefebvre. A Critical Introduction, New York.

Norrlid, Ingemar (1999), "Prövbarhet och relevans - Om minimikrav, optimumnormer och historieforskningens interna etiska kod", Research Report 1/99, Blekinge tekniska högskola. 
Olsson, Lars (1978), "Barnarbete i de svenska tobaksindustrierna", Scandia, Vol. $44 / 2$.

Schilhab, Theresa; Lindvall, Bo (2017), Naturlig laering, Aarhus.

Skogstad, Isak, "Vi behöver mer disciplin i skolan, Aftonbladet, 2018-10-03, https://www.aftonbladet.se/debatt/a/ngxEMd/vi-behover-mer-disciplin-i-skolan, 2019-06-13.

Stjärnresan 3. Noveller skrivna av femte- och sjundeklassare i Malmö (2018), Malmö.

Sundman-Marknäs, Anna (2008), "Från sillagumma till kaffeböna. En vandring i kvinnornas Malmö”, i Gå till historien (red:) Roger Johansson, Malmö.

Svensson Källberg, Petra (2018) Immigrant students' opportunities to learn mathematics. In(ex)clusion in mathematics education, Stockholm.

Tidman, Yngve (1998), Spräng Amalthea! Arbete, facklig kamp och strejkbryteri i nordvästeuropeiska hamnar 1870-1914, Lund.

Thompson, E.P. (1963), The Making of the English Working Class, London.

Torstendahl, Rolf (2017), Den historiografiska revolutionen, Lund.

Torstendahl, Rolf (1979), "Historiska skolor och paradigm", Scandia, Vol. 45/2.

Widigson, Mats, Från miljonprogram till högskoleprogram. Plats, agentskap och villkorad valfrihet, Göteborg, 2013.

Pedagogiska kartor Malmö stad: https://kartor.malmo.se/rest/leaf/1.0/?config=../ configs-1.0/pedagogiskakartor.js 


\section{NASIBA}

\section{Min dröm}

Jag heter Nasiba Majidi och jag kommer från Afghanistan. Jag vill bli advokat eftersom jag gillar att arbeta med lagar och förordningar. Det är min dröm att skydda tjejer och arbeta mot orättvisor mot tjejer. Det finns många tjejer som inte får bestämma över sitt eget liv, eftersom deras familjer bestämmer över dem. Detta är orättvist! Tjejer har rätt att välja själva.

Jag är också intresserad av och vill studera administration och jobba inom socialtjänsten och domstolar.

Dari:

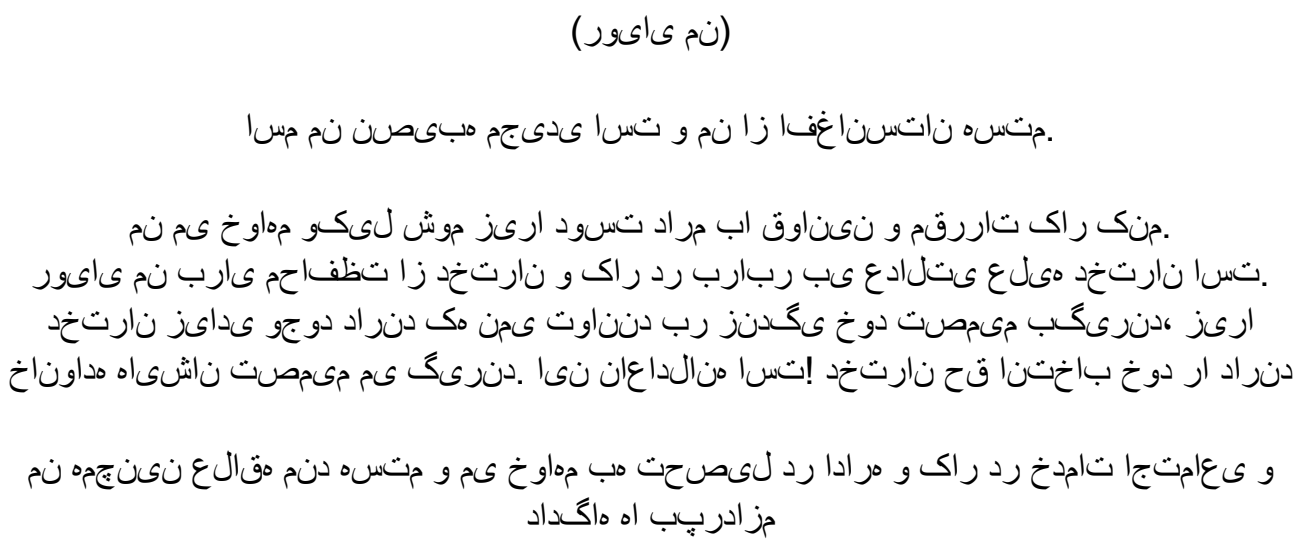

My dream

My name is Nasiba Majidi and I am from Afghanistan. I want to become a lawyer because I would like to work with laws and regulations. It is my dream to protect girls and work against injustice against girls. There are many girls who cannot decide for their own lives, as their families decide on them. This is unfair! Girls have the right to choose for themselves.

I am also interested in and want to study administration and work in the social services and courts. 


\section{Min dröm}

Hej!

Jag heter Natasha Shek och jag kommer från Somalia.

Jag har varit i Sverige ungefär två år med min familj. Min dröm är att jag vill bli sjuksköterska för att jag tycker om att hjälpa människor. Min andra dröm är att jag vill ha körkort och en ny bil. Jag vill ha mitt egen hus med min man och jag har många olika drömmer om framtiden som är litet svårt för mig men jag ska kämpa att jag skulle vilja göra allt jag drömmer om.

Arabiska:

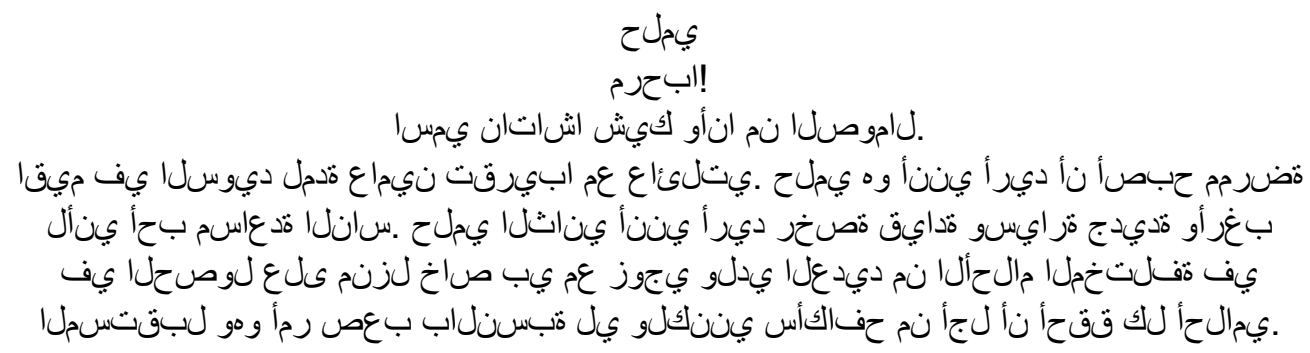

My dream

Hello!

My name is Natasha Shek and I'm from Somalia.

I have been in Sweden for about two years with my family. My dream is that I want to become a nurse because I like to help people. My second dream is that I want a driver's license and a new car. I want my own house with my husband and I have many different dreams about the future which will be a little difficult for me but I will fight on and do everything I dream about. 


\section{Min Dröm}

Jag heter Nathaniel. Jag är 18 år gammal. I framtiden vill jag bli författare. Det var en dröm som kom till mig när jag vaknade en dag och bestämde att skriva nånting kreativ. Efter att ha skrivit en stund såg jag att det var bra och spännande. Jag fortsatte att skriva och skriva och det blev spännande. Jag insåg också att kunskap är makt så jag vill sprida mer kunskap på ett kreativ sätt.

\section{My Dream}

My name is Nathaniel. I'm 18 years old. In the future, I want to be a writer. It was a dream that came to me when I woke up one day and decided to write something creative. After writing for awhile, I saw that it was good and exciting. I continued to write and write and it became more exciting. I realised that knowledge is power so I want to spread more knowledge through creative writing.

\section{Arabiska:}

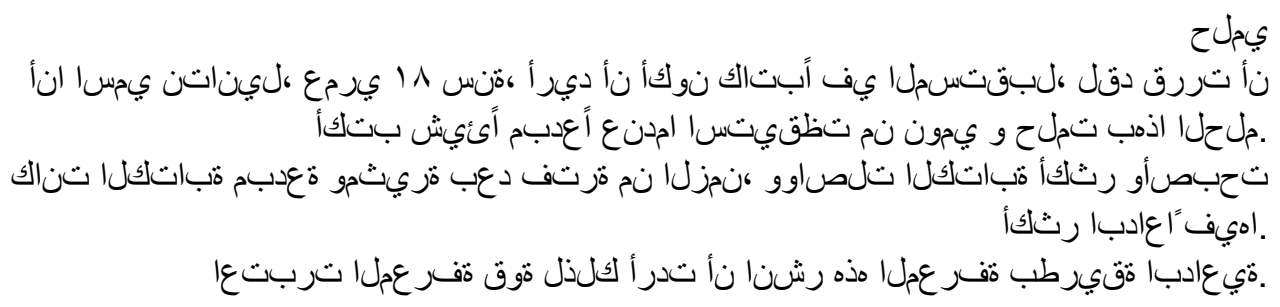

Nathaniel Yaw Ankomah Osei 


\section{SAMREEN}

\section{Min dröm}

Hej!

Jag heter Samreen och jag är från Pakistan. Jag har varit i Sverige i ungefär två år. Jag talar urdu, hindi, punjabi, engelska och snart svenska. Jag har många olika drömmar som att få körkort, ha bil, att lära mig svenska och åka till Tyskland mm, men en av de viktigaste är att bli administratör, för att jag tycker om att jobba digitalt. Jag skulle vilja jobba i domstolen. Jag tror att om jag kommer jobba med många olika människor i många olika situation, jag kommer att lär mig mycket och kan få mycket kunskap och det är bra. Då, kommer jag ha möjlighet att gå vidare med mina kunskap och drömmer.

\section{Urdu:}

Mera name Samreen hai or mein Pakistan se hon. Mujhe Sweden mein 2 saal ho chuke hai takriban. Me urdu, pujabi, hindi, english mn baat kr skti hon or swedish mera seekh rahi hon. Mere bohat sare sapne hai jase $k$ gari ka licence mujhe chahiye, gari chahiye, mein swedish bhi seekhna chahti hon och mera sapna hai $k$ mein jermany ka safer karu. Lekin in sab se zeyada zaruri mera ek sapna hai jo mein pura karna chahti hon mein administrator banna chahti hon kyu k mujhe digital kam krna acha lgta hai. Mujhe lagta hai k agr hum bohat sare muhtlif logo k sath bohat sari muhtlif situation mn kam kare to hum bohat he nolij hasil kar skte hai. Hammare pass moka hota hai age jane ka apni nolij or sapno $\mathrm{k}$ sath.

Hello!

My name is Samreen and I am from Pakistan. I have been in Sweden for about two years. I speak urdu, hindi, punjabi, english and little swedish. I have many different dreams like getting a driving license, having a car, learning Swedish and going to Germany but one of the most important is to become an administrator, because I enjoy working digitally. I would like to work in court. I think if I will work with many different people in many different situations, I will learn a lot and can get a lot of knowledge and that is good. Then, I will have the opportunity to move on with my knowledge and dreams. 


\section{Arabiska:}

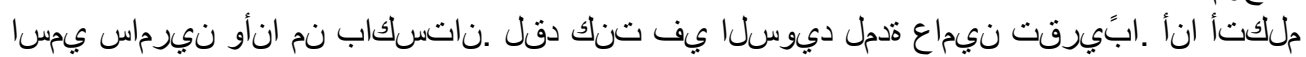

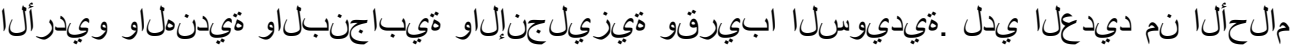

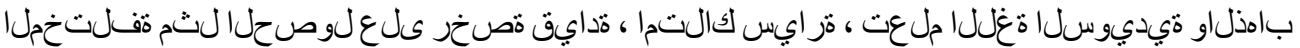

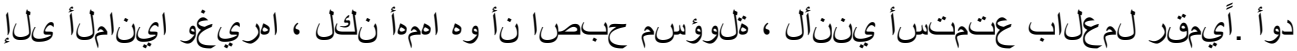

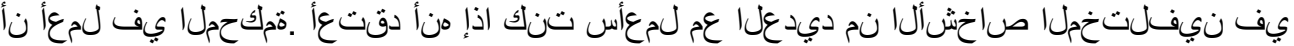

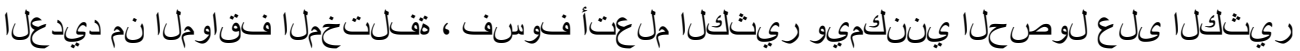

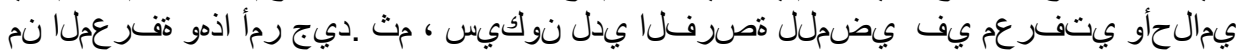

Samreen Bibi 


\section{TIDIGARE PUBLIKATIONER I MAPIUS}

1. Mikael Stigendal (2007) Allt som inte flyter. Fosies potentialer - Malmös problem

2. Ebba Lisberg Jensen \& Pernilla Ouis, red. (2008) Inne och ute i Malmö. Studier av urbana förändringsprocesser

3. Per Hillbur, red. (2009) Närnaturens mångfald. Planering och brukande av Arriesjöns strövområde

4. Johanna Sixtensson (2009) Hemma och främmande i staden. Kvinnor med slöja berättar

5. Per-Olof Hallin, Alban Jashari, Carina Listerborn \& Margareta Popoola (2010) Det är inte stenarna som gör ont. Röster från Herrgården, Rosengård - om konflikter och erkännande

6. Mikael Stigendal (2010) Cities and social cohesion. Popularizing the results of Social Polis

7. Mikael Stigendal, red. (2011) Det handlar om något större. Kunskaper om ungdomars möte med sin stad. Följeforskning om New City

8. Eva Öresjö, Gunnar Blomé \& Lars Pettersson (2012) En stadsdel byter skepnad. En utvärdering av förnyelsen på Öster i Gävle

9. Nicklas Guldåker \& Per-Olof Hallin (2013) Stadens bränder del I. Anlagda bränder och Malmös sociala geografi

10. Helena Bohman, Manne Gerell, Jonas Lundsten och Mona Tykesson (2013) Stadens bränder del 2. Fördjupning

11. Manne Gerell (2013) Bränder, skadegörelse, grannskap och socialt kapital

12. Mikaela Herbert (2013) Stadens skavsår. Inhägnade flerbostadshus i den polariserade staden

13. Eva Hedenfelt (2013) Hållbarhetsanalys av städer och stadsutveckling. Ett integrerat perspektiv på staden som ett socioekologiskt komplext system

14. Irene Andersson (2013) För några kvinnor tycks aldrig ha bott i Malmö. Om synlighet, erkännande och genus i berättelser om Malmö. Publicerad tillsammans med Institutet för studier i Malmös historia

15. Per-Olof Hallin (2013) Sociala risker: En begrepps- och metoddiskussion

16. Carina Listerborn, Karin Grundström, Ragnhild Claesson, Tim Delshammar, Magnus Johansson \& Peter Parker, red. (2014) Strategier för att hela en delad stad. Samordnad stadsutveckling i Malmö

17. Helena Bohman, Stig Westerdahl \& Eva Öresjö, red. (2014) Perspektiv på fastigheter 
18. Richard Ek, Manne Gerell, Nicklas Guldåker, Per-Olof Hallin, Mikaela Herbert, Tuija Nieminen Kristofersson, Annika Nilsson \& Mona Tykesson (2015) Att laga revor i samhällsväven - om social utsatthet och sociala risker i den postindustriella staden.

19. Helena Bohman \& Ola Jingryd (2015) BID Sofielund. Fastighetsägares roll i områdesutveckling.

20. Helena Bohman, Anders Edvik \& Mats Fred (2016) Nygammalt: rapport från områdesutveckling i Södra Sofielund/Seved, Malmö stad

21. Margareta Rämgård, Peter Håkansson \& Josefin Björk (2018) Det sociala sammanhanget. Om Finsam MittSkånes arbete mot utanförskap.

22. Guy Baeten, Fredrik Björk, Anders Edvik \& Peter Parker, eds. (2018) Reports from Urban Studies Research Internships 2017

23. Pål Brunnström \& Ragnhild Claesson (2019) Creating the City: Identity, Memory and Participation. Conference proceedings 